\title{
Research, Development and Demonstration of Bio-Mass Boiler for Food Industry Award DE-FC26-08NT05869 MOD 007
}

\author{
Final Technical Report \\ September 30, 2010 through March 31, 2012
}

\author{
Authors: \\ Steve Fisher, Retired, Oak Ridge National Laboratory \\ David R. Knapp, P.E., Burns \& McDonnell Engineering Company, Inc.
}

July 2012

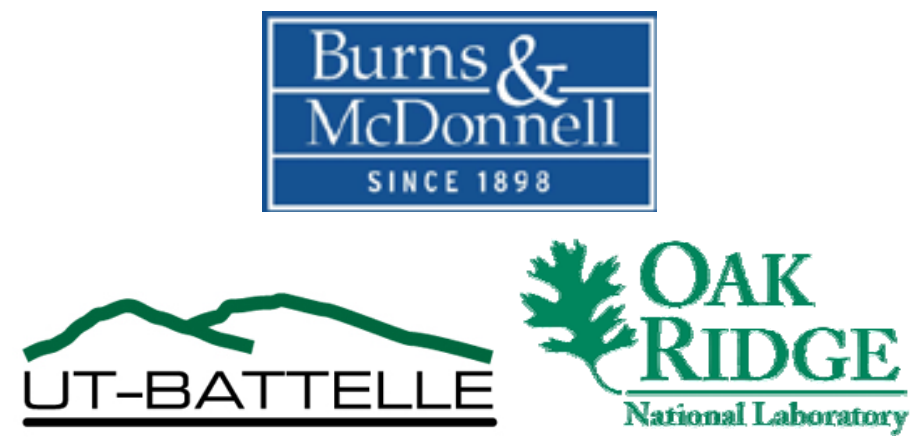

Prepared by

Oak Ridge National Laboratory and Burns \& McDonnell Engineering Company, Inc.

\section{DISCLAIMER}

This report was prepared as an account of work sponsored by an agency of the United States Government. Neither the United States Government nor any agency thereof, nor any of their employees, makes any warranty, express or implied, or assumes any legal liability or responsibility for the accuracy, completeness, or usefulness of any information, apparatus, product, or process disclosed, or represents that its use would not infringe privately owned rights. Reference herein to any specific commercial product, process, or service by trade name, trademark, manufacturer, or otherwise does not necessarily constitute or imply its endorsement, recommendation, or favoring by the United States Government or any agency thereof. The views and opinions of authors expressed herein do not necessarily state or reflect those of the United States Government or any agency thereof. 


\section{TABLE OF CONTENTS}

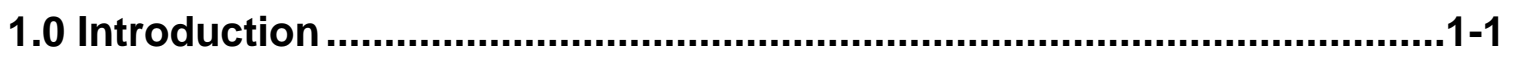

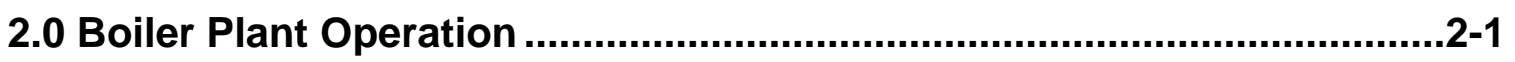

2.1 Fuel and Energy Consumption............................................................................... 2-1

2.2 Boiler Steam................................................................................................. 2-2

2.3 Ancillary Power Consumption............................................................................... 2-3

3.0 Additional Sources of Emissions .........................................................

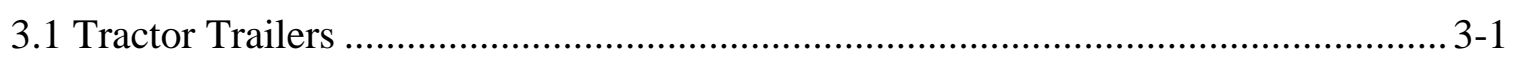

3.2 Front-End Loader................................................................................................ 3-1

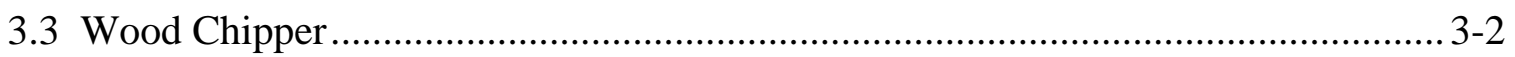

3.4 Summary of Emissions ……………………………........................................... 3-3

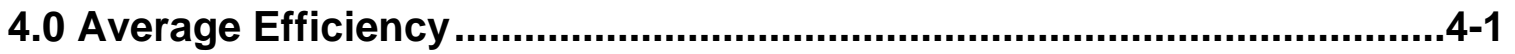

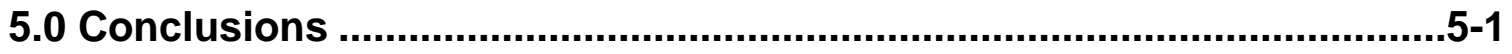

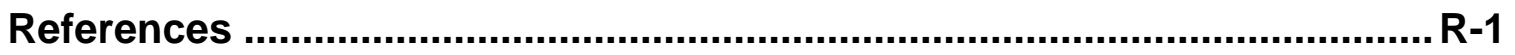

\section{APPENDIX A - OPERATING DATA}

APPENDIX B - BIOMASS BOILER ENERGY INPUTS

APPENDIX C - BIOMASS BOILER ENERGY OUTPUT

APPENDIX D - BIOMASS BOILER EFFICIENCY 


\section{LIST OF TABLES}

Table No.

Page No.

$1.1 \quad$ Biomass-Fired Boiler Data Summary ................................................................ 1-2

3.1 Summary of CO2 Emissions............................................................................ 3

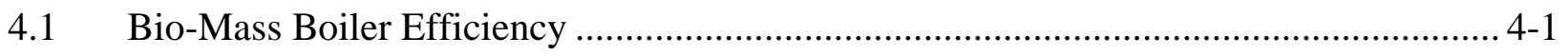

\section{Appendix Tables}

A.1 Dataset ID's and Data Collection Periods

A.2 Biomass Boiler Data

A.3 Biomass Boiler Fuel Input and Drag Chain Data

A.4 Biomass Boiler Fuel Metering Screws A1, A2, B1

A.5 Biomass Boiler Fuel Metering Screws B2, C1, C2

A.6 Biomass Boiler Fan Power Consumption and Operating Times

A.7 Babcock \& Wilcox Boiler Data

B.1 Biomass Boiler Energy Inputs: Wood, Tire-Derived Fuel, and Feedwater

B.2 Appendix Table Name

C.1 Biomass Boiler Energy Output

D.1 Biomass Boiler Efficiency 


\section{LIST OF FIGURES}

Figure No.

Page No.

$2.1 \quad$ Biomass boiler steam production............................................................................. 2-2

2.2 Main fuel conveyor belt.......................................................................................... 2-3

2.3 Biomass boiler average daily power consumption and average electrical demand......... 2-3

3.1 Wood fuel delivery by tractor trailer. ……………........................................................... 3-1

3.2 Front-end loader filling wood fuel hopper in the boiler fuel yard. .................................... 3-1

3.2 Gas powered wood shredding and chipping equipment. .................................................. 3-2 


\subsection{INTRODUCTION}

Frito-Lay is working to reduce carbon emissions from their manufacturing plants. As part of this effort, they invested in a "biomass-fired" boiler at the Topeka, Kansas, plant. Frito-Lay partnered with Burns \& McDonnell Engineering, Inc. and CPL Systems, Inc., to design and construct a steam producing boiler using “carbon neutral” fuels such as wood wastes (e.g. tree bark), shipping pallets, and used rubber vehicle tires [1]. Each of these materials releases the same amount of $\mathrm{CO}_{2}$ into the atmosphere whether they are burned to produce steam or degrade naturally over time in a landfill.

The U.S. Department of Energy (DOE) joined with Frito-Lay, Burns \& McDonnell, and CPL to analyze the reductions in carbon dioxide $\left(\mathrm{CO}_{2}\right)$ emissions that result from use of biomass-fired boilers in the food manufacturing environment. DOE support provided for the data collection and analysis, and reporting necessary to evaluate boiler efficiencies and reductions in $\mathrm{CO}_{2}$ emissions. The instrumentation and data collection for the biomass boiler demonstration and a preliminary analysis of the avoided $\mathrm{CO}_{2}$ emissions are documented elsewhere [2, 3].

This report constitutes the third, and final, analysis of the data collected on the Frito-Lay biomass-fired boiler. The data collected have been divided into three groupings:

- The boiler “commissioning” period from September 25, 2010 through December 31, 2010 (referred to subsequently as October 2010 through December 2010),

- The first calendar year of post-commissioning operation, January 1, 2011 through December 31, 2011, and

- 18 months of post-commissioning operation, January 1, 2011 through June 30, 2012. 
This report focuses on results for the two post-commissioning periods, although data are presented for the period covered in the preliminary analysis report [3], September 25, 2010 through September 30, 2011. Results are summarized in Table 1-1; with derivations of these results documented in sections 2 and 3 of this report.

\begin{tabular}{|l|r|r|r|}
\hline \multicolumn{4}{|c|}{ Table 1-1. Biomass-Fired Boiler Data Summary } \\
\hline Data Period & $\begin{array}{r}\text { Sep 25,2010 - } \\
\text { Sep 30,2011 }\end{array}$ & $\begin{array}{l}\text { Jan 1, 2011 - Dec } \\
31,2011\end{array}$ & $\begin{array}{l}\text { Jan 1, 2011 - Jun } \\
30,2012\end{array}$ \\
\hline $\begin{array}{l}\text { Biomass Consumed } \\
\text { wood waste } \\
\text { tire-derived fuel }\end{array}$ & $\begin{array}{r}29,120 \text { tons } \\
35 \text { tons }\end{array}$ & $\begin{array}{r}30,155 \text { tons } \\
35 \text { tons }\end{array}$ & $\begin{array}{r}43,991 \text { tons } \\
45 \text { tons }\end{array}$ \\
\hline Steam Produced & $270 \times 10^{6} \mathrm{lbs}$ & $283 \times 10^{6} \mathrm{lbs}$ & $424 \times 10^{6} \mathrm{lbs}$ \\
\hline $\begin{array}{l}\text { Avoided Natural Gas } \\
\text { Consumption }\end{array}$ & $398 \times 10^{6} \mathrm{scf}$ & $418 \times 10^{6} \mathrm{scf}$ & $626 \times 10^{6} \mathrm{scf}$ \\
\hline $\begin{array}{l}\text { Increased Power } \\
\text { Consumption }\end{array}$ & $995,000 \mathrm{kWh}$ & $1,056,000 \mathrm{kWh}$ & $1,642,000 \mathrm{kWh}$ \\
\hline $\begin{array}{l}\text { Net Reduction in } \mathrm{CO}_{2} \\
\text { emissions }\end{array}$ & 22,800 tons & 23,700 tons & $35,400 \mathrm{tons}$ \\
\hline
\end{tabular}




\subsection{BOILER PLANT OPERATION}

\subsection{FUEL AND ENERGY CONSUMPTION}

Five to seven tractor trailer loads of wood fuel are delivered daily under a long-term fuel contract with wood generally obtained from a composting and recycling center in the Topeka area. A diesel front-end loader is used to move the fuel onto an under pile drag chain conveyor into a hopper where oversize material is removed prior to feeding onto a conveyor belt and into the boiler. The amount of wood fuel fed into the boiler was determined to be linearly correlated upon the drag chain motor power consumption; this correlation and post-commissioning measurements of drive motor power consumption are used to estimate the tonnage of wood fed into the boiler during each reporting period.

A fuel sample is taken from one delivery of wood each week to test for moisture content and to verify that the fuel satisfies "quality” criteria of the purchase contract (e.g., particle size, presence of rocks, stones, dirt, and nails). The heat content of the wood fuel was also found to be linearly dependent on its moisture content. The average of the moisture content measurements during each reporting period is used to calculate the energy content of the fuel fed into the biomass boiler.

Wood fuel consumption is summarized in Table A-2. The wood heat capacity is based on information reported for January through June 2011; the average of these values, $6,340 \mathrm{Btu} / \mathrm{lb}$, is used for the periods not reported. Total wood fuel burned in the biomass boiler provided:

- $343,000 \times 10^{6}$ Btu of heat between September 1, 2010 and September 30, 2011,

- 283,000 x $10^{6}$ Btu of heat between January 1, 2011 and December 31, 2011, and

- 424,000 x 106 Btu of heat between January 1, 2011 and June 30, 2012.

Tire derived fuel (TDF) can be used as the supplemental fuel in firing the boiler. Its intended use is relegated to mixtures with the woody biomass should the wood fuel exhibit excessively high moisture content. The need for TDF has been limited. Heat content of TDF ranges from 10,900 to 13,500 Btu/lb [2]. TDF consumption is also summarized in Table A-2. A total of 992 x 106 Btu of energy was provided by TDF. 


\subsection{BOILER STEAM}

Use of the biomass boiler avoided emissions of $\mathrm{CO}_{2}$ that would have occurred by using the either of the existing plant's B\&W or the Nebraska boilers. Data for monthly steam output are shown in Fig. 2-1. These data indicate a low startup value and high peak during the commissioning period followed by steam production within a narrow range.

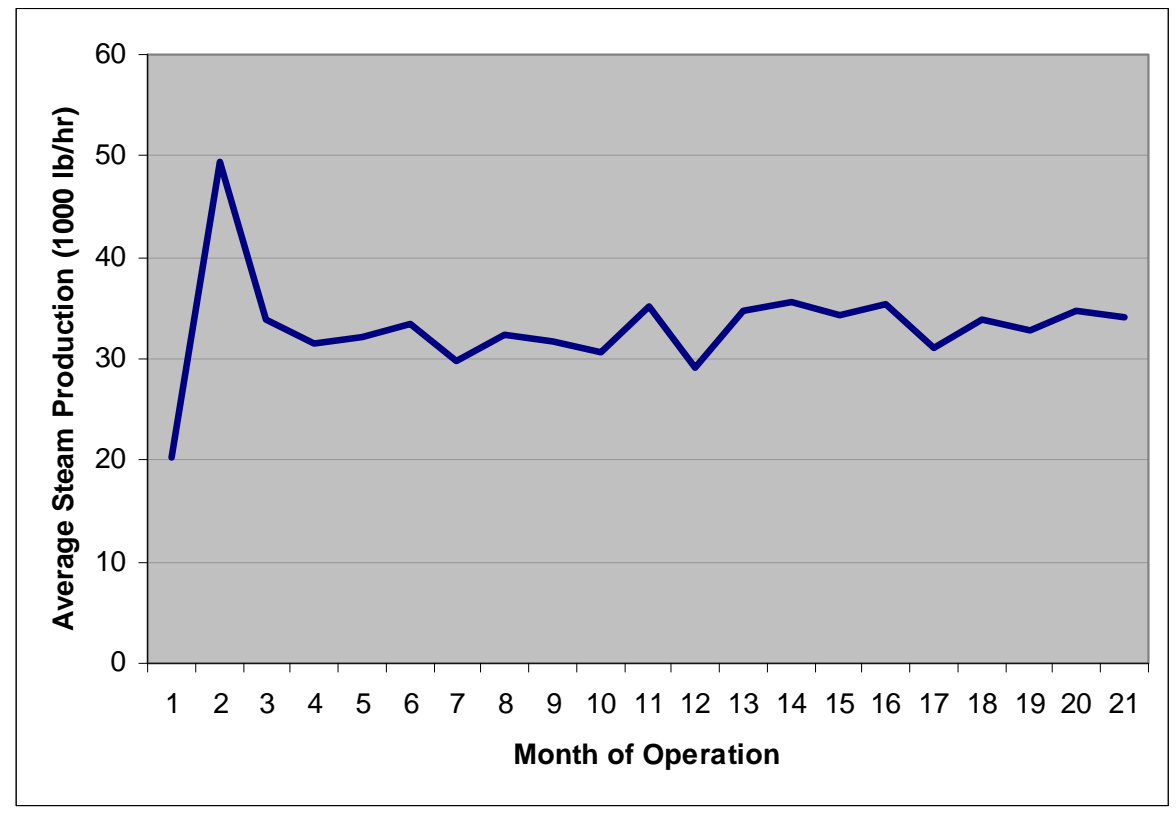

Fig. 2-1. Biomass boiler steam production.

Overall results on steam production show:

- $\quad 270,998$ thousand pounds of saturated steam (324,800 $\left.\mathrm{MMBtu}^{1}\right)$, avoiding the use of 398 million scf ${ }^{2}$ of natural gas and emissions of 23,880 tons $^{3}$ of $\mathrm{CO}_{2}$ for the first 12 months of operation (Oct 2010 - Sept 2011),

- $\quad$ 283,264 thousand pounds of saturated steam (341,300 MMBtu), avoiding the use of 418 million scf of natural gas and emissions of 25,100 tons of $\mathrm{CO}_{2}$ for 2011 (Jan 2011 - Dec 2011), and

\footnotetext{
${ }^{1}$ based on approximately 1,205 Btu/lb for saturated steam, varies with the steam drum pressure

${ }^{2}$ based on 1,020 Btu/standard cubic foot of natural gas and an average gas boiler efficiency of $80 \%$

${ }^{3}$ based on $120,000 \mathrm{lbs} \mathrm{CO}_{2} / 10^{6}$ scf of natural gas
} 
- $\quad 424,259$ thousand pounds of saturated steam (511,200 MMBtu), avoiding the use of 626 million scf of natural gas and emissions of 37,600 tons of $\mathrm{CO}_{2}$ for the postcommissioning period (Jan 2011 - June 2012).

\subsection{ANCILLARY POWER CONSUMPTION}

The biomass boiler employs electrical

subsystems for fuel delivery, combustion air, and ash removal that are not required by natural gas-fired boiler. These include large fans, motors for conveyor belts (Fig. 2-2) and an electrostatic precipitator.

Data for the average electrical demand for the motors, fans, and precipitator and for the

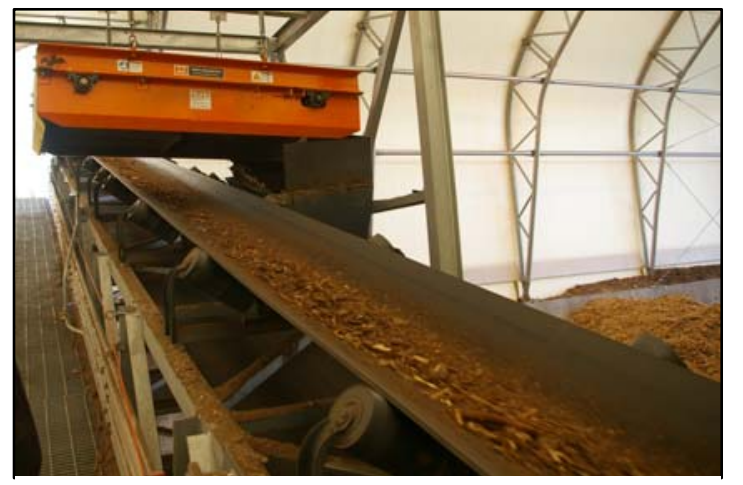

Figure 2-2. Main fuel conveyor belt. average daily power consumption are shown

Fig. 2-3. The demand (blue line) ranges from 108 to $143 \mathrm{~kW}$ and is trending upward in the later months of operation. The average daily power consumption (red line) ranges from 2,325 $\mathrm{kWh} /$ day to 3,452 $\mathrm{kWh} /$ day. It is also trending upward. EPA reported an annual average emission rate of 1,960 lbs/MWh for the region including Topeka [6].

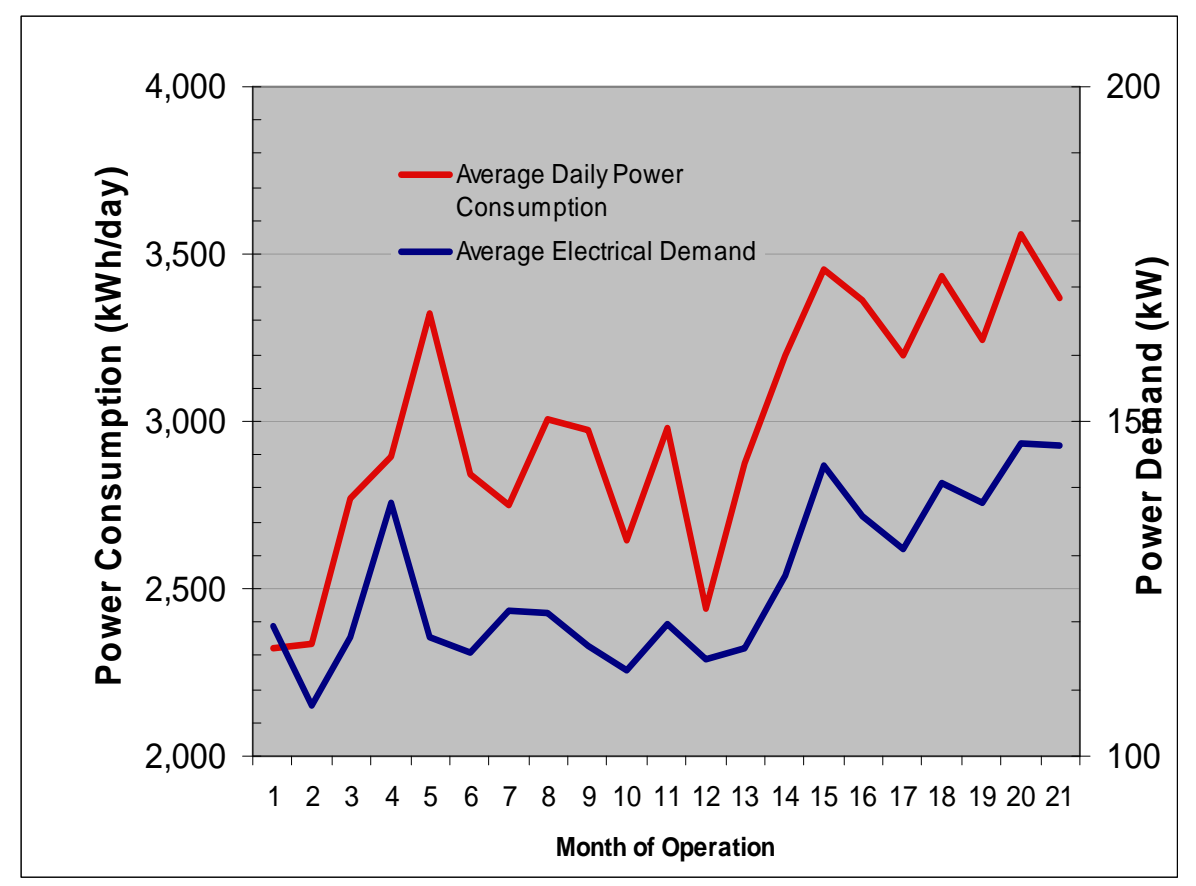

Fig. 2-3. Biomass boiler average daily power consumption and average electrical demand. 
Power consumption for the biomass boiler and the associated $\mathrm{CO}_{2}$ emissions are summarized below:

- $994,548 \mathrm{kWh}$ and 970 tons of $\mathrm{CO}_{2}$ for the first 12 months of operation (Oct 2010 - Sept 2011),

- 1,056,358 kWh and 1,040 tons of $\mathrm{CO}_{2}$ for 2011 (Jan 2011 - Dec 2011), and

- 1,641,684 kWh and 1,610 tons of $\mathrm{CO}_{2}$ for the post-commissioning period (Jan 2011 June 2012). 


\subsection{ADDITIONAL SOURCES OF EMISSIONS}

\subsection{TRACTOR TRAILERS}

Five to seven truck loads of wood fuel are delivered to the biomass boiler fuel yard each day (Fig. 3-1). These deliveries are made from recycle/compost facilities near Topeka. The $\mathrm{CO}_{2}$ emissions associated with fuel deliveries are estimated assuming a tractor-trailer "efficiency" of $5.6 \mathrm{mpg}$ or 91 ton-miles / gallon of diesel fuel for a 63,000 pound rig. Diesel fuel consumption ${ }^{4}$ was thus:

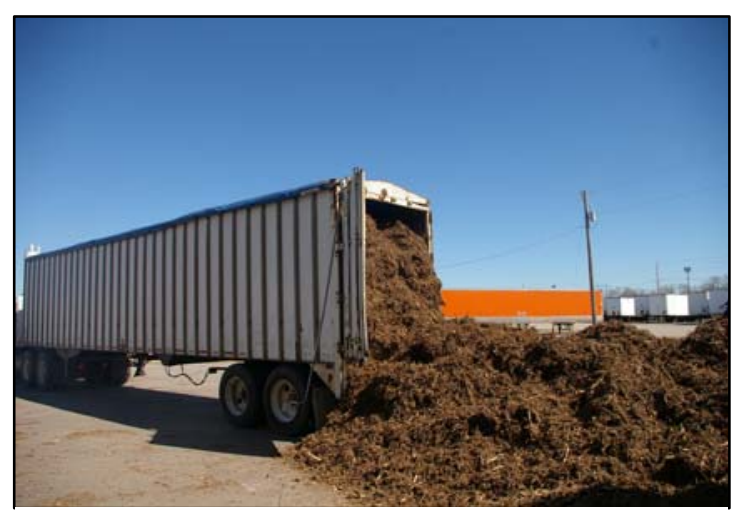

Figure 3-1. Wood fuel delivery by tractor trailer.

- 16,000 gallons for the first 12 months of operation (Oct 2010 - Sept 2011),

- 16,570 gallons for 2011 (Jan 2011 - Dec 2011), and

- 24,170 gallons for the post-commissioning period (Jan 2011 - June 2012).

Diesel fuel averages 139,400 Btu/gallon [12] with $\mathrm{CO}_{2}$ emissions of $164 \mathrm{lbs} / 10^{6}$ Btu fuel input [13]; $22.8 \mathrm{lbs} \mathrm{CO}_{2}$ /gallon. Emissions from fuel deliveries are thus approximately:

- 180 tons for the first 12 months of operation (Oct 2010 - Sept 2011),

- 190 tons for 2011 (Jan 2011 - Dec 2011), and

- 280 tons for the post-commissioning period (Jan 2011 - June 2012).

\subsection{FRONT-END LOADER}

The wood fuel is moved about the biomass boiler fuel yard and put into a fuel hopper using a diesel powered front-end loader (Fig. 3-2). There is no log of fuel use or operating times for the front-end loader. Fuel consumption is approximately 1.00 gallons/hour [14]. It was assumed that the front-end loader was either in

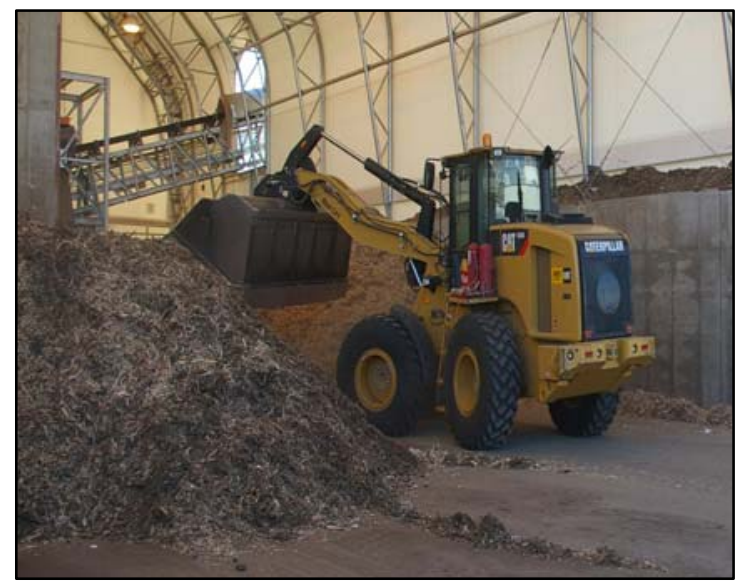

Figure 3-2. Front-end loader filling wood fuel hopper in the boiler fuel yard.

\footnotetext{
${ }^{4}$ Based on an average distance of 25 miles between the fuel source and the Frito-Lay plant.
} 
use or idling whenever the biomass boiler was operating (this estimate is known to be on the high side).

Diesel fuel consumption was thus:

- 8,380 gallons for the first 12 months of operation (Oct 2010 - Sept 2011),

- 8,640 gallons for 2011 (Jan 2011 - Dec 2011), and

- 12,830 gallons for the post-commissioning period (Jan 2011 - July 2012).

Operation of the front-end loader resulted in emissions of:

- 100 tons of $\mathrm{CO}_{2}$ for the first 12 months of operation (Oct 2010 - Sept 2011),

- 100 tons for 2011 (Jan 2011 - Dec 2011), and

- 130 tons for the post-commissioning period (Jan 2011 - June 2012).

\subsection{WOOD CHIPPER}

The wood delivered to the biomass boiler fuel yard was ground, shredded, or chipped at a composting company before being sorted and shipped to Frito-Lay (Fig. 3-3). Arguably the fuel consumed in this process could be considered a source of $\mathrm{CO}_{2}$ related to that's plant operation and not part of the biomass boiler plant's operation. Gasoline powered industrial wood

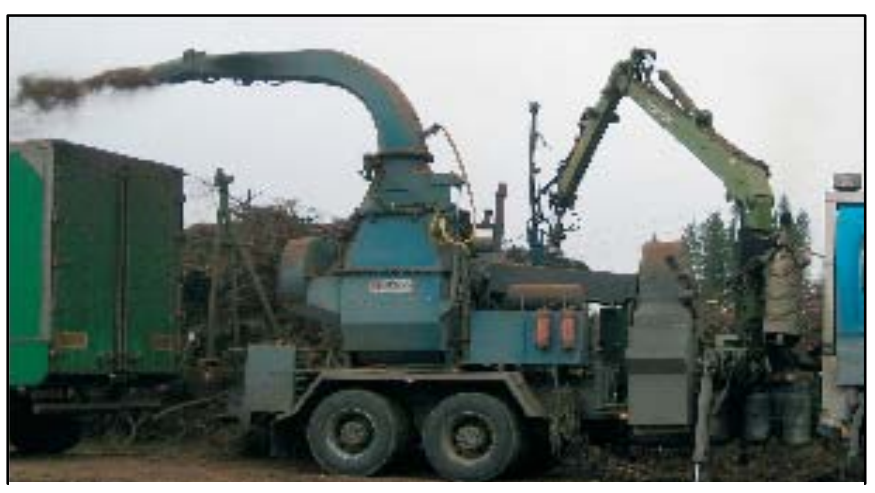

Figure 3-3. Gas powered wood shredding and chipping equipment. chippers average approximately $7.25 \mathrm{lb} \mathrm{CO}_{2}$ /ton of wood processed [15]. The biomass boiler monthly wood fuel consumption was multiplied by this factor and summed for the year to estimate $\mathrm{CO}_{2}$ emissions for chipping the wood fuel ${ }^{5}$ :

- 110 tons of $\mathrm{CO}_{2}$ for the first 12 months of operation (Oct 2010 - Sept 2011),

- 110 tons for 2011 (Jan 2011 - Dec 2011), and

- 140 tons for the post-commissioning period (Jan 2011 - June 2012).

\footnotetext{
${ }^{5}$ Based on 19.4 lbs $\mathrm{CO}_{2} /$ gallon of gasoline [16]
} 


\subsection{SUMMARY OF EMISSIONS}

Carbon dioxide emissions for operation of the biofuel boiler are summarized in Table 3-1. Analysis of the data for 2011 and 2012 show net reductions of 23,660 tons of $\mathrm{CO}_{2}$ for the calendar year 2011 and 35,390 tons for the post-commissioning period January 2011 through June 2012.

\begin{tabular}{|c|c|c|c|c|}
\hline \multicolumn{5}{|c|}{ Table 3.1 - Summary of $\mathrm{CO}_{2}$ Emissions } \\
\hline & \multirow{2}{*}{$\begin{array}{l}\text { Preliminary Report } \\
\text { First } 12 \text { Months }\end{array}$} & \multirow[b]{2}{*}{ Commissioning } & \multicolumn{2}{|c|}{ Post-Commissioning } \\
\hline & & & 12 Months & 18 Months \\
\hline & Oct ’10 - Sep ‘11 & Oct '10- Dec' '10 & Jan '11 - Dec '11 & Jan '11 - Jun '12 \\
\hline $\begin{array}{l}\text { Avoided Emissions } \\
\text { natural gas }\end{array}$ & 23,880 & 5,880 & 25,100 & 37.590 \\
\hline $\begin{array}{l}\text { Increased } \\
\text { Emissions } \\
\text { electricity } \\
\text { diesel fuel } \\
\text { gasoline } \\
\text { total }\end{array}$ & $\begin{array}{r}970 \\
280 \\
110 \\
1,360\end{array}$ & $\begin{array}{r}230 \\
60 \\
20 \\
310\end{array}$ & $\begin{array}{r}1,040 \\
290 \\
110 \\
1,440\end{array}$ & $\begin{array}{r}1,610 \\
430 \\
160 \\
2,200\end{array}$ \\
\hline $\begin{array}{l}\text { Net Reduction in } \\
\mathrm{CO}_{2} \text { Emissions }\end{array}$ & 22,520 & 5,570 & 23,660 & 35,390 \\
\hline
\end{tabular}


Biomass Boiler

Final Operating Report

July 2012

Average Efficiency

\subsection{AVERAGE EFFICIENCY}

Table 4-1 contains monthly efficiency data that was calculated from performance data logged from the boiler data acquisition system and reported on a monthly basis. These values use published properties for saturated steam and returning boiler concentrate and also monthly average heat content for samples of wood fuel.

Table 4-1. Bio-Mass Boiler Efficiency

\begin{tabular}{|c|c|}
\hline & $\begin{array}{c}\text { Calculated } \\
\text { Boiler }\end{array}$ \\
\hline Reporting Period & Efficiency \\
\hline October 2010 & $N / A^{6}$ \\
\hline November 2010 & N/A \\
\hline December 2010 & N/A \\
\hline January 2011 & $74.6 \%$ \\
\hline February 2011 & $80.5 \%$ \\
\hline March 2011 & $79.9 \%$ \\
\hline April 2011 & $70.0 \%$ \\
\hline May 2011 & $72.0 \%$ \\
\hline June 2011 & $74.9 \%$ \\
\hline July 2011 & $70.6 \%$ \\
\hline August 2011 & $74.1 \%$ \\
\hline September 2011 & $71.4 \%$ \\
\hline October 2011 & $84.3 \%$ \\
\hline November 2011 & $81.5 \%$ \\
\hline December 2011 & $74.4 \%$ \\
\hline January 2012 & $79.9 \%$ \\
\hline February 2012 & $81.4 \%$ \\
\hline March 2012 & $78.4 \%$ \\
\hline April 2012 & $78.9 \%$ \\
\hline May 2012 & $76.2 \%$ \\
\hline June 2012 & $77.8 \%$ \\
\hline
\end{tabular}

\footnotetext{
${ }^{6}$ wood moisture content and heating value not available
} 
Biomass Boiler

Final Operating Report

July 2012

Conclusions

\subsection{CONCLUSIONS}

The Frito-Lay biomass-fired boiler has resulted in significant reductions in $\mathrm{CO}_{2}$ emissions from the Topeka production facility. The use of natural gas has been reduced by 400 to 420 million standard cubic feet per year with corresponding reductions of 24,000 to 25,000 tons of $\mathrm{CO}_{2}$. The boiler does require auxiliary "functions," however, that are unnecessary for a gas-fired boiler. These include heavy motors and fans for moving fuel and firing the boiler, trucks and equipment for delivering the fuel and moving at the boiler plant, and chippers for preparing the fuel prior to delivery. Each of these operations requires the combustion of fossil fuels or electricity and has associated $\mathrm{CO}_{2}$ emissions. Even after accounting for each of these auxiliary processes, however, the biomass-fired boiler results in net emission reductions of 22,500 to 23,500 tons of $\mathrm{CO}_{2}$ per year. 


\section{References}

1. Knapp, David, R., 2011, Research, Development, and Demonstration of Biomass Boiler for Food Industry: Post Commissioning Test Assessment Report, January 28, 2011.

2. ORNL 2011, Research, Development, and Demonstration of Bio-Mass Boiler for Food Industry: Instrumentation and Data Collection Report, Oak Ridge National Laboratory, October 2011.

3. ORNL 2011, Performance of a Demonstration Biomass-fired Boiler in the Food Processing Industry, Oak Ridge National Laboratory and Burns \& McDonnell Engineering Company, November 2011.

3. Strait, R., et al, Draft Kansas Greenhouse Gas Inventory and Reference Case Projections 1990-2025, Center for Climate Strategies, May 2008.

4. EPA 1998, AP42 Fifth Edition, Compilation of Air Pollutant Emission Factors, Volume 1: Stationary Point and Area Sources, Section 1.4, Table 1.4-2, http://www.epa.gov/ttnchie1/ap42/, 1998.

5. EPA 2002, eGRID2000, data for WestStar Energy, 2002.

6. EPA 2005, eGRID2007, Version 1.1 Year 2005 GHG Annual Output Emission Rates, 2005.

7. Knapp, D., personal communication, December 2011.

8. Baumel, C. Phillip, Hurbugh, Charles R., and Lee, Tenpao, Estimates of Total Fuel Consumption in Transporting Grain from Iowa to Major Grain Countries by Alternative Modes and Routes, Iowa State University, 2011.

9. EPA 2010, EPA and NHTSA Propose First-Ever Program to Reduce Greenhouse Gas Emissions and Improve Fuel Efficiency of Medium- and Heavy-Duty Vehicles: Regulatory Announcement, EPA-420-F-10-901, October 2010.

10. DOT 2010, Factors and Considerations for Establishing a Fuel Efficiency Regulatory Program for Commercial Medium- and Heavy-Duty Vehicles, p. 91, DOT HS 811 XXX, U.S. Department of Transportation, October 2010.

11. NESCCAF 2009, Reducing Heavy-Duty Long Haul Combination Truck Fuel Consumption and $\mathrm{CO}_{2}$ Emissions, Northeast States Center for a Clean Air Future, International Council on Clean Transportation, Southwest Research Institute, and TIAC LLC, p. 51, October 2009.

12. ASHRAE 2005, Handbook: Fundamentals, p. 18.6. 2005

13. EPA 1998a, AP42 Fifth Edition, Compilation of Air Pollutant Emission Factors, Volume 1: Stationary Point and Area Sources, Section 3.3, Table 3.3-1, p. 6, http://www.epa.gov/ttnchie1/ap42/, 1998.

14. Frey, Christopher, et al 2007, Methodology for Activity, Fuel Use, and Emissions Data Collection and Analysis for Non-road Construction Equipment, 16th Annual International Emission Inventory Conference, Slide 14, North Carolina University, May 2007.

15. Röser, Dominik, METLA Infor-Card 9, Wood Chippers, Joensuu, Finland, www.northernwoodheat.net/htm/Publications/FinnishInfoCard9.pdf.

16. EPA 2005, Emission Facts: Average Carbon Dioxide Emissions Resulting from Gasoline and Diesel Fuel, EPA420-F-05-001, February 2005. 
APPENDIX A: OPERATING DATA 
Table A.1 - Dataset ID's and Data Collection Periods

\begin{tabular}{|c|c|}
\hline Dataset ID & Data Collection Period \\
\hline October 2010 & 9/25/2010 through $11 / 2 / 10$ \\
\hline November 2010 & $11 / 03 / 2010$ through $11 / 30 / 10$ \\
\hline December 2010 & $12 / 01 / 2010$ through $12 / 31 / 10$ \\
\hline January 2011 & 1/01/2011 through $2 / 1 / 11$ \\
\hline February 2011 & 2/01/2011 through $3 / 1 / 11$ \\
\hline March 2011 & 3/1/2011 through $4 / 4 / 11$ \\
\hline April 2011 & 4/4/2011 through $5 / 2 / 11$ \\
\hline May 2011 & 5/3/2011 through 6/1/11 \\
\hline June 2011 & 6/2/2011 through $7 / 4 / 11$ \\
\hline July 2011 & 7/4/2011 through $7 / 29 / 11$ \\
\hline August 2011 & 7/30/2011 through $9 / 1 / 11$ \\
\hline September 2011 & 9/1/2011 through 9/30/11 \\
\hline October 2011 & 10/1/2011 through $10 / 31 / 11$ \\
\hline November 2011 & $11 / 1 / 2011$ through $11 / 30 / 11$ \\
\hline December 2011 & 12/1/2011 through $1 / 04 / 12$ \\
\hline January 2012 & 1/1/2012 through $2 / 01 / 12$ \\
\hline February 2012 & 2/2/2012 through 3/01/12 \\
\hline March 2012 & 3/1/2012 through 4/01/12 \\
\hline April 2012 & 4/1/2012 through 5/01/12 \\
\hline May 2012 & 5/1/2012 through 6/01/2012 \\
\hline June 2012 & 6/2/2012 through $7 / 2 / 2012$ \\
\hline
\end{tabular}


Table A.2 - Biomass Boiler Data

\begin{tabular}{|c|c|c|c|c|c|c|c|}
\hline Dataset ID & $\begin{array}{l}\text { Steam } \\
\text { Flow } \\
\text { Total } \\
(\mathrm{kpph})\end{array}$ & $\begin{array}{c}\text { Feedwater } \\
\text { Flow Total } \\
\text { (kpph) }\end{array}$ & $\begin{array}{l}\text { Boiler Run } \\
\text { Hours } \\
\text { (hrs) }\end{array}$ & $\begin{array}{l}\text { Drum } \\
\text { Pressure } \\
\text { Average } \\
\text { (psi) }\end{array}$ & $\begin{array}{l}\text { Header } \\
\text { Pressure } \\
\text { Average } \\
\text { (psi) }\end{array}$ & $\begin{array}{c}\text { Boiler } \\
\text { Feedwater } \\
\text { Pressure } \\
\text { Average } \\
\text { (psi) }\end{array}$ & $\begin{array}{c}\text { Boiler } \\
\text { Feedwater } \\
\text { Temperature } \\
\left({ }^{\circ} \mathrm{F}\right)\end{array}$ \\
\hline October 2010 & 14,950 & 16,002 & 739 & 320 & 330 & 365 & 315 \\
\hline November 2010 & 28,950 & 1,998 & 586 & 329 & 332 & 391 & 315 \\
\hline December 2010 & 23,879 & 1,998 & 706 & 322 & 325 & 388 & 319 \\
\hline January 2011 & 20,552 & 25,000 & 651 & 338 & 343 & 390 & 319 \\
\hline February 2011 & 24,551 & 25,476 & 761 & 326 & 331 & 387 & 319 \\
\hline March 2011 & 27,189 & 28,724 & 811 & 330 & 335 & 386 & 319 \\
\hline April 2011 & 18,255 & 18,896 & 611 & 327 & 332 & 366 & 319 \\
\hline May 2011 & 23,217 & 25,498 & 718 & 332 & 337 & 385 & 319 \\
\hline June 2011 & 25,968 & 28,290 & 817 & 315 & 321 & 351 & 317 \\
\hline July 2011 & 17,206 & 19,066 & 563 & 332 & 337 & 386 & 319 \\
\hline August 2011 & 28,917 & 31,870 & 822 & 328 & 333 & 368 & 319 \\
\hline September 2011 & 17,364 & 18,763 & 597 & 332 & 337 & 392 & 321 \\
\hline October 2011 & 25,929 & 29,427 & 744 & 328 & 333 & 373 & 321 \\
\hline November 2011 & 25,975 & 30,031 & 730 & 335 & 340 & 386 & 321 \\
\hline December 2011 & 28,141 & 31,057 & 819 & 330 & 335 & 395 & 321 \\
\hline January 2012 & 23,639 & 24,506 & 668 & 336 & 341 & 392 & 321 \\
\hline February 2012 & 21,326 & 22,096 & 684 & 334 & 339 & 396 & \\
\hline March 2012 & 24,800 & 25,544 & 732 & 326 & 331 & 394 & \\
\hline April 2010 & 22,427 & 23,186 & 682 & 329 & 334 & 379 & \\
\hline May 2012 & 25,299 & 26,384 & 727 & 334 & 339 & 386 & \\
\hline June 2012 & 23,504 & 25,328 & 691 & 331 & 336 & 367 & \\
\hline \multicolumn{8}{|l|}{ Totals } \\
\hline Commissioning & 67,779 & 19,998 & 2,031 & & & & \\
\hline First year & 283,264 & 312,098 & 8,644 & & & & \\
\hline 18 months & 424,259 & 459,142 & 12,828 & & & & \\
\hline To date & 492,038 & 479,140 & 14,859 & & & & \\
\hline
\end{tabular}




\begin{tabular}{|c|c|c|c|c|c|c|}
\hline \multicolumn{7}{|c|}{ Table A.3 - Biomass Boiler Fuel Input and Drag Chain Data } \\
\hline Dataset ID & $\begin{array}{l}\text { Wood } \\
\text { Fuel } \\
\text { Total } \\
\text { (tons) }\end{array}$ & $\begin{array}{c}\text { Tire } \\
\text { Derived } \\
\text { Fuel Total } \\
\text { (tons) }\end{array}$ & $\begin{array}{c}\text { Main Fuel } \\
\text { Drag Chain } \\
\text { KW Total } \\
(\mathrm{kWh})\end{array}$ & $\begin{array}{c}\text { Main Fuel } \\
\text { Drag Chain } \\
\text { Run Time } \\
\text { (hrs) }\end{array}$ & $\begin{array}{c}\text { Tire Derived } \\
\text { Fuel Metering } \\
\text { Screw KW } \\
\text { Total } \\
\text { (kWh) }\end{array}$ & $\begin{array}{c}\text { Tire Derived } \\
\text { Fuel Metering } \\
\text { Screw Run } \\
\text { Time } \\
\text { (hrs) }\end{array}$ \\
\hline October 2010 & 2,071 & 0 & 935 & 685 & 0 & 0 \\
\hline November 2010 & 2,073 & 0 & 1,146 & 572 & 0 & 0 \\
\hline December 2010 & 2,073 & 0 & 1,334 & 666 & 0 & 0 \\
\hline January 2011 & 4,182 & 0 & 1,274 & 601 & 0.71 & 2.01 \\
\hline February 2011 & 2,322 & 8.59 & 1,324 & 709 & 13.70 & 73.99 \\
\hline March 2011 & 2,640 & 23.92 & 1,548 & 783 & 43.41 & 316.00 \\
\hline April 2011 & 2,003 & 2.40 & 882 & 579 & 7.70 & 400.00 \\
\hline May 2011 & 2,398 & 0 & 1,150 & 610 & 0 & 0 \\
\hline June 2011 & 2,600 & 0 & 1,269 & 660 & 0 & 0 \\
\hline July 2011 & 1,890 & 0 & 818 & 442 & 0 & 0 \\
\hline August 2011 & 2,992 & 0 & 1,324 & 683 & 0 & 0 \\
\hline September 2011 & 1,876 & 0 & 851 & 448 & 0 & 0 \\
\hline October 2011 & 2,244 & 0 & 1,127 & 616 & 0 & 0 \\
\hline November 2011 & 2,339 & 0 & 1,266 & 590 & 0 & 0 \\
\hline December 2011 & 2,669 & 0 & 1,615 & 669 & 0 & 0 \\
\hline January 2012 & 2,250 & 0 & 1,350 & 549 & 0 & 0 \\
\hline February 2012 & 1,987 & 0 & 1,289 & 539 & 0 & 0 \\
\hline March 2012 & 2,423 & 0 & 1,532 & 626 & 0 & 0 \\
\hline April 2012 & 2,169 & 0 & 1,346 & 555 & 0 & 0 \\
\hline May 2012 & 2,538 & 8.48 & 1,597 & 555 & 22.93 & 687 \\
\hline June 2012 & 2,469 & 1.92 & 1,430 & 580 & 3.85 & 349 \\
\hline \multicolumn{7}{|l|}{ Totals } \\
\hline Commissioning & 6,217 & 0.00 & 3,415 & 1,923 & 0 & 0 \\
\hline First year & 30,155 & 35.12 & 14,448 & 7,390 & 66 & 792 \\
\hline 18 months & 43,991 & 45.52 & 22,992 & 11,440 & 92 & 1,828 \\
\hline To date & 50,208 & 45.52 & 26,407 & 13,363 & 92 & 1,828 \\
\hline
\end{tabular}


Table A.4 - Biomass Boiler Fuel Metering Screws A1, A2, B1: Power Consumption and Operating Times

\begin{tabular}{|c|c|c|c|c|c|c|}
\hline Dataset ID & $\begin{array}{c}\text { Fuel } \\
\text { Metering } \\
\text { Screw A1 } \\
\text { KW Total } \\
\text { (kWh) }\end{array}$ & $\begin{array}{c}\text { Fuel } \\
\text { Metering } \\
\text { Screw A1 } \\
\text { Run Time } \\
\text { (hrs) }\end{array}$ & $\begin{array}{c}\text { Fuel } \\
\text { Metering } \\
\text { Screw A2 } \\
\text { KW Total } \\
\text { (kWh) }\end{array}$ & $\begin{array}{c}\text { Fuel } \\
\text { Metering } \\
\text { Screw A2 } \\
\text { Run Time } \\
\text { (hrs) }\end{array}$ & $\begin{array}{c}\text { Fuel } \\
\text { Metering } \\
\text { Screw B1 } \\
\text { KW Total } \\
\text { (kWh) }\end{array}$ & $\begin{array}{c}\text { Fuel } \\
\text { Metering } \\
\text { Screw B1 } \\
\text { Run Time } \\
\text { (hrs) }\end{array}$ \\
\hline October 2010 & 219 & 709 & 166 & 716 & 1,737 & 720 \\
\hline November 2010 & 218 & 582 & 168 & 583 & 1,432 & 584 \\
\hline December 2010 & 241 & 706 & 185 & 706 & 1,670 & 706 \\
\hline January 2011 & 211 & 621 & 167 & 621 & 1,484 & 622 \\
\hline February 2011 & 275 & 746 & 210 & 747 & 1,713 & 744 \\
\hline March 2011 & 316 & 807 & 245 & 807 & 1,897 & 807 \\
\hline April 2011 & 231 & 594 & 175 & 594 & 1,392 & 595 \\
\hline May 2011 & 268 & 704 & 217 & 704 & 1,632 & 704 \\
\hline June 2011 & 288 & 817 & 238 & 816 & 1,886 & 812 \\
\hline July 2011 & 228 & 539 & 188 & 540 & 1,283 & 540 \\
\hline August 2011 & 353 & 820 & 301 & 821 & 1,950 & 820 \\
\hline September 2011 & 245 & 570 & 197 & 569 & 1,363 & 571 \\
\hline October 2011 & 290 & 742 & 230 & 743 & 1,734 & 744 \\
\hline November 2011 & 285 & 695 & 221 & 696 & 1,613 & 695 \\
\hline December 2011 & 292 & 816 & 238 & 817 & 1,891 & 815 \\
\hline January 2012 & 268 & 669 & 221 & 669 & 1,572 & 669 \\
\hline February 2012 & 230 & 673 & 183 & 673 & 1,566 & 673 \\
\hline March 2012 & 255 & 727 & 214 & 727 & 1,686 & 727 \\
\hline April 2010 & 218 & 660 & 186 & 661 & 1,520 & 662 \\
\hline May 2012 & 274 & 723 & 241 & 723 & 1,679 & 723 \\
\hline June 2012 & 261 & 671 & 226 & 671 & 1,535 & 675 \\
\hline \multicolumn{7}{|l|}{ Totals } \\
\hline Commissioning & 678 & 1,997 & 519 & 2,005 & 4,839 & 2,010 \\
\hline First year & 3,282 & 8,471 & 2,627 & 8,475 & 19,838 & 8,469 \\
\hline 18 months & 4,788 & 12,594 & 3,898 & 12,599 & 29,396 & 12,598 \\
\hline To date & 5,466 & 14,591 & 4,417 & 14,604 & 34,235 & 14,608 \\
\hline
\end{tabular}




\begin{tabular}{|c|c|c|c|c|c|c|}
\hline \multicolumn{7}{|c|}{$\begin{array}{l}\text { Table A.5 - Biomass Boiler Fuel Metering Screws B2, C1, C2: } \\
\text { Power Consumption and Operating Times }\end{array}$} \\
\hline Dataset ID & $\begin{array}{c}\text { Fuel } \\
\text { Metering } \\
\text { Screw B2 } \\
\text { KW Total } \\
\text { (kWh) }\end{array}$ & $\begin{array}{c}\text { Fuel } \\
\text { Metering } \\
\text { Screw B2 } \\
\text { Run Time } \\
\text { (hrs) }\end{array}$ & $\begin{array}{c}\text { Fuel } \\
\text { Metering } \\
\text { Screw C1 } \\
\text { KW Total } \\
\text { (kWh) }\end{array}$ & $\begin{array}{c}\text { Fuel } \\
\text { Metering } \\
\text { Screw C1 } \\
\text { Run Time } \\
\text { (hrs) }\end{array}$ & $\begin{array}{c}\text { Fuel } \\
\text { Metering } \\
\text { Screw C2 } \\
\text { KW Total } \\
\text { (kWh) }\end{array}$ & $\begin{array}{c}\text { Fuel } \\
\text { Metering } \\
\text { Screw C2 } \\
\text { Run Time } \\
\text { (hrs) }\end{array}$ \\
\hline October 2010 & 232 & 720 & 260 & 709 & 277 & 693 \\
\hline November 2010 & 246 & 584 & 303 & 576 & 308 & 575 \\
\hline December 2010 & 272 & 706 & 358 & 702 & 353 & 720 \\
\hline January 2011 & 251 & 621 & 293 & 611 & 300 & 590 \\
\hline February 2011 & 239 & 745 & 263 & 749 & 266 & 748 \\
\hline March 2011 & 270 & 806 & 319 & 805 & 291 & 805 \\
\hline April 2011 & 187 & 595 & 241 & 594 & 313 & 594 \\
\hline May 2011 & 214 & 701 & 257 & 704 & 274 & 705 \\
\hline June 2011 & 216 & 812 & 291 & 814 & 298 & 814 \\
\hline July 2011 & 146 & 540 & 241 & 539 & 261 & 539 \\
\hline August 2011 & 274 & 821 & 381 & 821 & 407 & 821 \\
\hline September 2011 & 171 & 569 & 249 & 529 & 278 & 569 \\
\hline October 2011 & 216 & 744 & 236 & 784 & 249 & 744 \\
\hline November 2011 & 210 & 695 & 282 & 697 & 297 & 697 \\
\hline December 2011 & 242 & 815 & 313 & 818 & 323 & 818 \\
\hline January 2012 & 209 & 668 & 280 & 668 & 285 & 668 \\
\hline February 2012 & 188 & 674 & 244 & 673 & 252 & 673 \\
\hline March 2012 & 210 & 732 & 288 & 727 & 296 & 726 \\
\hline April 2010 & 190 & 656 & 243 & 661 & 243 & 660 \\
\hline May 2012 & 235 & 724 & 302 & 722 & 305 & 722 \\
\hline June 2012 & 229 & 674 & 279 & 672 & 290 & 670 \\
\hline \multicolumn{7}{|l|}{ Totals } \\
\hline Commissioning & 750 & 2,010 & 921 & 1,987 & 938 & 1,988 \\
\hline First year & 2,636 & 8,464 & 3,366 & 8,465 & 3,557 & 8,444 \\
\hline 18 months & 3,897 & 12,592 & 5,002 & 12,588 & 5,228 & $-87,319$ \\
\hline To date & 4,647 & 14,602 & 5,923 & 14,575 & 6,166 & $-85,331$ \\
\hline
\end{tabular}




\begin{tabular}{|c|c|c|c|c|c|c|}
\hline \multicolumn{7}{|c|}{ Table A.6 - Biomass Boiler Fan Power Consumption and Operating Times } \\
\hline Dataset ID & $\begin{array}{c}\text { Forced } \\
\text { Draft Fan } \\
\text { KW Total } \\
\text { (kWh) }\end{array}$ & $\begin{array}{c}\text { Forced } \\
\text { Draft Fan } \\
\text { Run Time } \\
\text { (hrs) }\end{array}$ & $\begin{array}{c}\text { Induced } \\
\text { Draft Fan } \\
\text { KW Total } \\
\text { (kWh) }\end{array}$ & $\begin{array}{c}\text { Induced } \\
\text { Draft Fan } \\
\text { Run Time } \\
\text { (hrs) }\end{array}$ & $\begin{array}{c}\text { OFA Fan } \\
\text { KW Total } \\
(\mathrm{kWh})\end{array}$ & $\begin{array}{c}\text { OFA Fan } \\
\text { Run Time } \\
\text { (hrs) }\end{array}$ \\
\hline October 2010 & 0 & 0 & 41,485 & 759 & 36,231 & 723 \\
\hline November 2010 & 0 & 0 & 31,574 & 605 & 22,741 & 605 \\
\hline December 2010 & 0 & 0 & 43,188 & 711 & 31,223 & 710 \\
\hline January 2011 & 6,856 & 2,680 & 44,863 & 648 & 29,800 & 644 \\
\hline February 2011 & 2,472 & 761 & 44,348 & 761 & 33,354 & 761 \\
\hline March 2011 & 2,654 & 812 & 46,406 & 811 & 34,046 & 811 \\
\hline April 2011 & 2,298 & 610 & 36,552 & 627 & 26,635 & 610 \\
\hline May 2011 & 2,780 & 718 & 42,575 & 719 & 31,732 & 719 \\
\hline June 2011 & 3,288 & 817 & 44,901 & 816 & 35,882 & 817 \\
\hline July 2011 & 2,267 & 563 & 28,746 & 568 & 24,731 & 563 \\
\hline August 2011 & 3,259 & 822 & 42,611 & 823 & 41,556 & 822 \\
\hline September 2011 & 2,551 & 597 & 30,464 & 597 & 26,965 & 574 \\
\hline October 2011 & 2,829 & 744 & 40,573 & 744 & 33,426 & 744 \\
\hline November 2011 & 3,556 & 730 & 48,901 & 733 & 32,140 & 707 \\
\hline December 2011 & 4,538 & 819 & 60,083 & 820 & 44,017 & 819 \\
\hline January 2012 & 3,715 & 668 & 46,101 & 668 & 34,507 & 669 \\
\hline February 2012 & 3,353 & 684 & 43,164 & 684 & 33,590 & 675 \\
\hline March 2012 & 3,879 & 732 & 49,841 & 732 & 37,514 & 732 \\
\hline April 2010 & 3,802 & 682 & 46,513 & 683 & 34,315 & 682 \\
\hline May 2012 & 5,212 & 727 & 55,973 & 727 & 35,648 & 727 \\
\hline June 2012 & 5,621 & 691 & 53,563 & 691 & 34,129 & 813 \\
\hline \multicolumn{7}{|l|}{ Totals } \\
\hline Commissioning & 0 & 0 & 116,247 & 2,075 & 90,195 & 2,038 \\
\hline First year & 39,348 & 10,673 & 511,023 & 8,667 & 394,284 & 8,591 \\
\hline 18 months & 64,930 & 14,857 & 806,178 & 12,852 & 603,987 & 12,889 \\
\hline To date & 64,930 & 14,857 & 922,425 & 14,927 & 694,182 & 14,927 \\
\hline
\end{tabular}




\begin{tabular}{|c|c|c|c|c|}
\hline \multicolumn{5}{|c|}{ Table A.7 - Babcock \& Wilcox Boiler Data } \\
\hline Dataset ID & $\begin{array}{c}\text { Babcock \& Wilcox } \\
\text { Fuel Flow Total } \\
\text { (kscfh) }\end{array}$ & $\begin{array}{c}\text { Babcock \& Wilcox } \\
\text { Run Hours Total } \\
\text { (hrs) }\end{array}$ & $\begin{array}{c}\text { Babcock \& Wilcox } \\
\text { Boiler Low } \\
\text { Turndown Hours } \\
\text { (hrs) }\end{array}$ & $\begin{array}{c}\text { Babcock \& Wilcox } \\
\text { Forced Draft Fan } \\
\text { KW Total } \\
\text { (kWh) }\end{array}$ \\
\hline October 2010 & 14,182 & 739 & 262 & 15,850 \\
\hline November 2010 & 14,182 & 739 & 473 & 15,850 \\
\hline December 2010 & 14,182 & 739 & 681 & 15,850 \\
\hline January 2011 & 9,992 & 1,920 & 513 & 30,961 \\
\hline February 2011 & 2,110 & 748 & 681 & 11,885 \\
\hline March 2011 & 647 & 805 & 795 & 11,724 \\
\hline April 2011 & 5,847 & 596 & 401 & 10,966 \\
\hline May 2011 & 4,169 & 706 & 576 & 11,172 \\
\hline June 2011 & 1,693 & 817 & 751 & 11,869 \\
\hline July 2011 & 1,758 & 539 & 514 & 8,496 \\
\hline August 2011 & 878 & 822 & 795 & 11,850 \\
\hline September 2011 & 5,343 & 572 & 525 & 11,306 \\
\hline October 2011 & 698 & 743 & 726 & 10,607 \\
\hline November 2011 & 1,000 & 697 & 674 & 10,664 \\
\hline December 2011 & 576 & 820 & 800 & 11,594 \\
\hline January 2012 & 229 & 668 & 664 & 9,413 \\
\hline February 2012 & 834 & 674 & 666 & 9,975 \\
\hline March 2012 & 1,363 & 726 & 682 & 11,286 \\
\hline April 2010 & 1,886 & 661 & 604 & 10,277 \\
\hline May 2012 & 1,618 & 724 & 660 & 10,775 \\
\hline June 2012 & 3,772 & 675 & 642 & 11,938 \\
\hline \multicolumn{5}{|l|}{ Totals } \\
\hline Commissioning & 42,546 & 2,217 & 1,416 & 47,550 \\
\hline First year & 34,711 & 9,785 & 7,751 & 153,094 \\
\hline 18 months & 44,413 & 13,913 & 11,668 & 216,758 \\
\hline To date & 86,959 & 16,130 & 13,084 & 264,308 \\
\hline
\end{tabular}


APPENDIX B - BIOMASS BOILER ENERGY INPUTS 


\begin{tabular}{|c|c|c|c|c|c|c|c|c|c|c|}
\hline & \multicolumn{3}{|c|}{ Wood Fuel } & \multicolumn{2}{|c|}{ Tire-Derived Fuel } & \multicolumn{4}{|c|}{ Boiler Feedwater } & \multirow[b]{2}{*}{$\begin{array}{l}\text { Total Heat } \\
\text { Input } \\
\text { (MMBtu) }\end{array}$} \\
\hline & $\begin{array}{l}\text { Consumption } \\
\text { (tons) }\end{array}$ & $\begin{array}{l}\text { Specific } \\
\text { Heat }^{1} \\
(\mathrm{Btu} / \mathrm{lbm})\end{array}$ & $\begin{array}{c}\text { Heat } \\
\text { Content } \\
\left(\mathrm{MMBtu}^{2}\right)\end{array}$ & $\begin{array}{l}\text { Consumption } \\
\text { (tons) }\end{array}$ & $\begin{array}{c}\text { Heat } \\
\text { Content } \\
\text { (MMBtu) }\end{array}$ & $\begin{array}{l}\text { Feedwater } \\
\text { Flow } \\
\text { (thousand } \\
\text { lbs) }\end{array}$ & $\begin{array}{c}\text { Temperature } \\
\left({ }^{\circ} \mathrm{F}\right)\end{array}$ & $\begin{array}{c}\text { Specific } \\
\text { Heat } \\
\text { (Btu/lbm) }\end{array}$ & $\begin{array}{c}\text { Heat } \\
\text { Content } \\
\text { (MMBtu) }\end{array}$ & \\
\hline October 2010 & 2,071 & $6,340^{4}$ & 26,300 & 0 & 0 & 16,002 & 315 & 285.4 & 4,567 & 30,867 \\
\hline November 2010 & 2,073 & $6,340^{4}$ & 26,300 & 0 & 0 & 1,998 & 319 & 289.6 & 570 & 26,870 \\
\hline $\begin{array}{l}\text { December } 2010 \\
\text { Subtotal } 2010\end{array}$ & $\begin{array}{l}\frac{2,091}{6,235} \\
6\end{array}$ & $\begin{array}{r}\text { 6,340 } \\
--\end{array}$ & $\frac{26,500}{79,100}$ & $\frac{0}{0}$ & $\underline{0}$ & $\frac{1,998}{19,998}$ & $\begin{array}{r}319 \\
---\end{array}$ & $\begin{array}{r}289.6 \\
---\end{array}$ & $5, \frac{579}{716}$ & $\frac{27,079}{84,816}$ \\
\hline January 2011 & 2,091 & 6,200 & 25,900 & 0.213 & 4.6 & 25,000 & 319 & 289.6 & 7,239 & 33,144 \\
\hline February 2011 & 2,322 & 6,280 & 29,200 & 8.592 & 187.3 & 25,476 & 319 & 289.6 & 7,377 & 36,764 \\
\hline March 2011 & 2,640 & 6,090 & 32,200 & 23,915 & 521.3 & 28,724 & 319 & 289.6 & 8,317 & 41,038 \\
\hline April 2011 & 2,003 & 6,460 & 25,900 & 2.397 & 52.3 & 18,896 & 319 & 289.6 & 5,471 & 31,423 \\
\hline May 2011 & 2,398 & 6,560 & 31,500 & 0 & 0 & 25,498 & 317 & 287.5 & 7,383 & 38,883 \\
\hline June 2011 & 2,600 & 6,450 & 33,500 & 0 & 0 & 28,290 & 319 & 289.6 & 8,133 & 41,633 \\
\hline July 2011 & 1,890 & $6,340^{4}$ & 24,000 & 0 & 0 & 19,066 & 319 & 289.6 & 5,521 & 29,521 \\
\hline August 2011 & 2,992 & $6,340^{4}$ & 37,900 & 0 & 0 & 31,870 & 319 & 289.6 & 9,228 & 47,128 \\
\hline September 2011 & 1,876 & $6,340^{4}$ & 23,800 & 0 & 0 & 18,763 & 321 & 291.6 & 5,472 & 29,272 \\
\hline
\end{tabular}




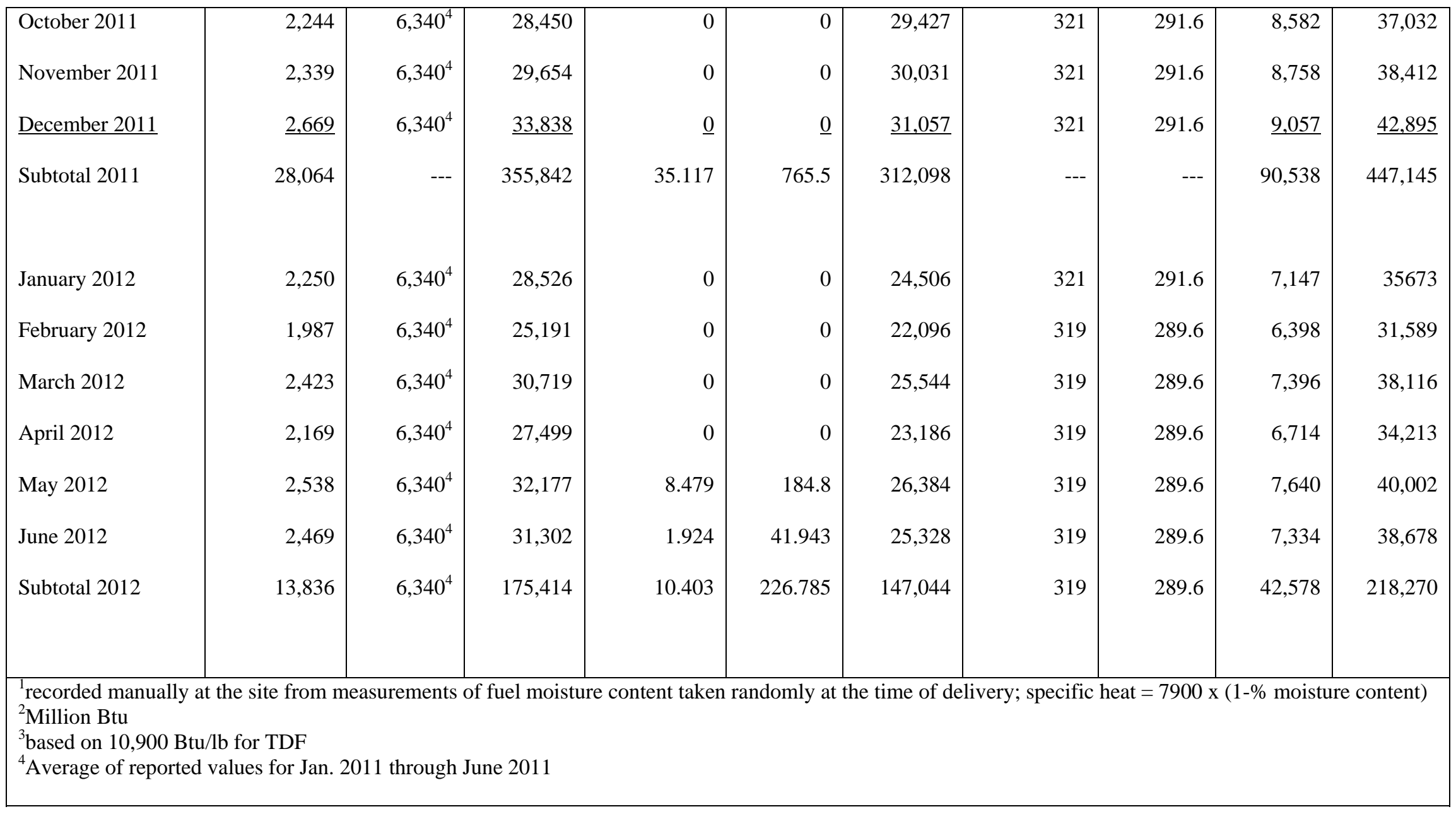


APPENDIX C - BIOMASS BOILER ENERGY OUTPUT 


\begin{tabular}{|c|c|c|c|c|}
\hline \multicolumn{5}{|c|}{ Table C.1 - Biomass Boiler Energy Output } \\
\hline Data ID & $\begin{array}{c}\text { Steam } \\
\text { Produced } \\
\text { (thousand lbs) }\end{array}$ & $\begin{array}{l}\text { Header } \\
\text { Pressure } \\
\text { (psig) }\end{array}$ & $\begin{array}{l}\text { Specific } \\
\text { Heat }^{1} \\
(\mathrm{Btu} / \mathrm{lb})\end{array}$ & $\begin{array}{l}\text { Steam Output } \\
\left(\mathrm{MMBtu}^{2}\right)\end{array}$ \\
\hline October 2010 & 14,950 & 330.0 & $1,204.9$ & 18,000 \\
\hline November 2010 & 28,950 & 332.0 & $1,204.9$ & 34,900 \\
\hline December 2010 & 23,879 & 325.0 & $1,204.8$ & 28,800 \\
\hline Subtotal 2010 & 67,779 & --- & --- & 81,700 \\
\hline January 2011 & 20,552 & 343.0 & $1,205.1$ & 24,800 \\
\hline February 2011 & 24,551 & 331.0 & $1,204.9$ & 29,600 \\
\hline March 2011 & 27,189 & 335.0 & $1,205.0$ & 32,800 \\
\hline April 2011 & 18,255 & 332.1 & $1,204.9$ & 22,000 \\
\hline May 2011 & 23,217 & 336.9 & $1,205.0$ & 28,000 \\
\hline June 2011 & 25,968 & 320.5 & $1,204.7$ & 31,300 \\
\hline July 2011 & 17,206 & 337.5 & $1,205.0$ & 20,700 \\
\hline August 2011 & 28,917 & 332.7 & $1,204.9$ & 34,800 \\
\hline September 2011 & 17,364 & 336.6 & $1,205.0$ & 20,900 \\
\hline October 2011 & 25,929 & 333.4 & $1,205.1$ & 31,200 \\
\hline November 2011 & 25,975 & 340.2 & $1,205.2$ & 31,300 \\
\hline December 2011 & 28,141 & 335.4 & $1,205.2$ & 31,900 \\
\hline Subtotal 2011 & 283,264 & --- & --- & 339,300 \\
\hline January 2012 & 23,639 & 340.7 & $1,205.2$ & 28,500 \\
\hline February 2012 & 21,326 & 339.2 & $1,205.2$ & 25,700 \\
\hline March 2012 & 24,800 & 331.4 & $1,205.1$ & 29,900 \\
\hline April 2012 & 22,427 & 334.1 & $1,205.1$ & 27,000 \\
\hline
\end{tabular}




\begin{tabular}{|l|r|r|r|r|}
\hline May 2012 & 25,299 & 334.0 & $1,205.2$ & 30,500 \\
\hline June 2012 & 23,504 & 330.9 & $1,205.2$ & 28,300 \\
\hline Subtotal 2012 & 140,995 & & & 169,900 \\
\hline & 492,038 & --- & --- & 590,900 \\
\hline Total & & & & \\
\hline $\begin{array}{l}{ }^{1} \text { Calculated for saturated vapor at the steam header pressure using REFPROP from the } \\
\text { National Institute of Standards and Technology } \\
{ }^{2} \text { Million Btu }\end{array}$ \\
\hline
\end{tabular}


APPENDIX D - BIOMASS BOILER EFFICIENCY 


\begin{tabular}{|c|c|c|c|c|}
\hline \multicolumn{5}{|c|}{ Table D.1 - Biomass Boiler Efficiency } \\
\hline Data ID & $\begin{array}{l}\text { Steam Output } \\
\left(\mathrm{MMBtu}^{1}\right)\end{array}$ & $\begin{array}{l}\text { Fuel \& Feed- } \\
\text { Water Input } \\
\text { (MMBtu) }\end{array}$ & $\begin{array}{l}\text { Calculated } \\
\text { Efficiency }\end{array}$ & $\begin{array}{l}\text { Reported } \\
\text { Efficiency }\end{array}$ \\
\hline September 2010 & 18,000 & 30,867 & $58.3 \%$ & $75 \%$ \\
\hline November 2010 & 34,900 & 26,870 & $129.9 \%$ & $80 \%$ \\
\hline December 2010 & 28,800 & 27,079 & $106.4 \%$ & $76 \%$ \\
\hline Subtotal 2010 & 81,700 & 84,816 & & \\
\hline January 2011 & 24,800 & 33,144 & $74.8 \%$ & $69 \%$ \\
\hline February 2011 & 29,600 & 36,764 & $80.5 \%$ & $65 \%$ \\
\hline March 2011 & 32,800 & 41,038 & $79.9 \%$ & $61 \%$ \\
\hline April 2011 & 22,000 & 31,423 & $70.0 \%$ & $63 \%$ \\
\hline May 2011 & 28,000 & 38,883 & $72.0 \%$ & $68 \%$ \\
\hline June 2011 & 31,300 & 41,633 & $75.2 \%$ & $54 \%$ \\
\hline July 2011 & 20,700 & 29,521 & $70.1 \%$ & $67 \%$ \\
\hline August 2011 & 34,800 & 47,128 & $73.8 \%$ & $66 \%$ \\
\hline September 2011 & 20,900 & 29,272 & $71.4 \%$ & $62 \%$ \\
\hline October 2011 & 31,200 & 37,032 & $84.3 \%$ & $79 \%$ \\
\hline November 2011 & 31,300 & 38,412 & $81.5 \%$ & $73 \%$ \\
\hline December 2011 & 33,900 & 42,895 & $79.0 \%$ & $72 \%$ \\
\hline Subtotal 2011 & 341,300 & 447,145 & $76.3 \%$ & ---- \\
\hline January 2012 & 28,500 & 35,673 & $79.9 \%$ & $72 \%$ \\
\hline February 2012 & 25,700 & 31,589 & $81.4 \%$ & $80 \%$ \\
\hline March 2012 & 29,900 & 38,116 & $78.4 \%$ & $66 \%$ \\
\hline April 2012 & 27,000 & 34,213 & $78.9 \%$ & $65 \%$ \\
\hline
\end{tabular}


Appendix D

\begin{tabular}{|l|r|r|r|r|}
\hline May 2012 & 30,500 & 40,002 & $76.2 \%$ & $65.3 \%$ \\
\hline June 2012 & 28,300 & 38,678 & $73.2 \%$ & $62.0 \%$ \\
\hline Subtotal 2012 & 169,900 & 218,271 & $73.2 \%$ & \\
\hline & & & & \\
\hline Total & 590,900 & 750,232 & $78.8 \%$ & \\
\hline${ }^{1}$ Million Btu & & & & \\
\hline
\end{tabular}




\title{
AMPAC FINE CHEMICALS BYPRODUCT FUEL AND CHP FEASIBILITY STUDY Award DE-FC26-08NT05869 Task 2.3
}

\author{
Final Technical Report \\ September 30, 2010 through March 31, 2012
}

\author{
Authors: \\ Kris Chatrathi, P.E., Burns \& McDonnell Engineering Company, Inc. \\ Duane DeRaad, Burns \&McDonnell Engineering Company, Inc.
}

March 20, 2012

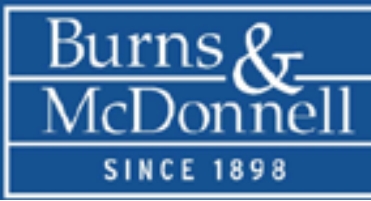

Prepared by

\section{Burns \& McDonnell Engineering Company, Inc.}

\section{DISCLAIMER}

This report was prepared as an account of work sponsored by an agency of the United States Government. Neither the United States Government nor any agency thereof, nor any of their employees, makes any warranty, express or implied, or assumes any legal liability or responsibility for the accuracy, completeness, or usefulness of any information, apparatus, product, or process disclosed, or represents that its use would not infringe privately owned rights. Reference herein to any specific commercial product, process, or service by trade name, trademark, manufacturer, or otherwise does not necessarily constitute or imply its endorsement, recommendation, or favoring by the United States Government or any agency thereof. The views and opinions of authors expressed herein do not necessarily state or reflect those of the United States Government or any agency thereof. 
March 20, 2012

Mr. Paul Kane

Vice President

Chief Financial Officer

AMPAC Fine Chemicals

P.O. Box 1718

Rancho Cordova, CA 95741-1718

AMPAC Fine Chemicals Byproduct Fuel and CHP Feasibility Study

Burns \& McDonnell Project No. 63327

Dear Mr. Kane,

Burns \& McDonnell is pleased to present this report on the AMPAC Fine Chemicals (AFC) Byproduct Fuel and Combined Heat and Power (CHP) Feasibility Study (the Study) completed on behalf of the U.S. Department of Energy/National Energy Technology Laboratory (U.S. DOE/NETL), AMPAC Fine Chemicals LLC (AFC) and the Sacramento Municipal Utility District (SMUD). This report was prepared and is submitted pursuant to the Agreement between U.S. DOE/NETL, AFC, SMUD and Burns \& McDonnell dated.

This report describes the approach and assumptions used in the analyses completed for SMUD and it presents the results of the Study completed, including conclusions and recommendations.

The results of the study are outlined in the following sections:

- Introduction \& Executive Summary

- Description of Existing Plant

- Site Energy Requirements

- Waste Fuels Analysis

- CHP Options, Capital Cost, and Operation and Maintenance Costs

- Economic Analysis

Based on the assessment completed by Burns \& McDonnell, a number of conclusions and recommendations were developed and are provided in the Executive Summary section of the report. Burns \& McDonnell appreciates the opportunity to work with SMUD and AFC.

We are grateful for the cooperation and assistance we received. Please call us with any questions or comments you may have regarding this report.

Sincerely,

Duane DeRaad, LEED AP

Project Manager

BURNS \& MCDONNELL; 


\section{TABLE OF CONTENTS}

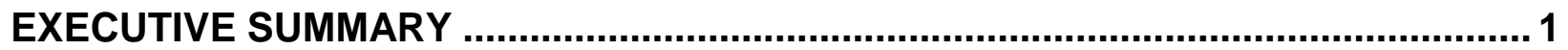

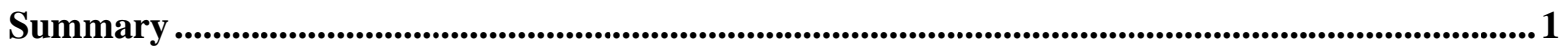

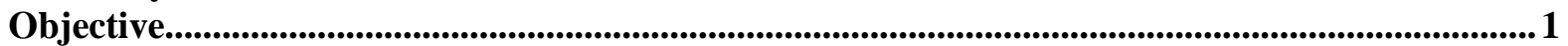

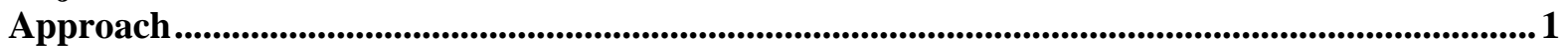

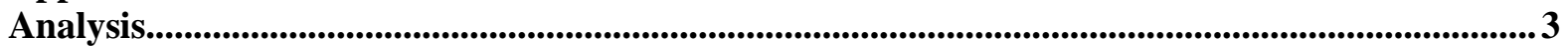

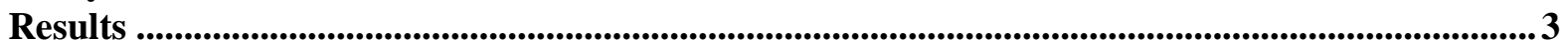

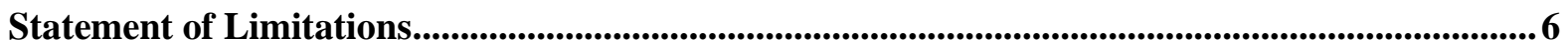

1.0 DESCRIPTION OF EXISTING PLANT ....................................................1-1

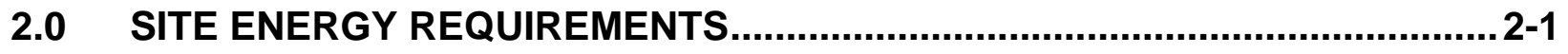

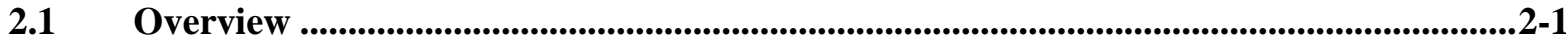

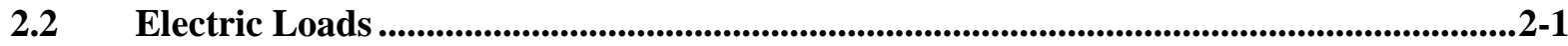

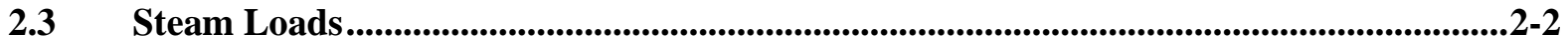

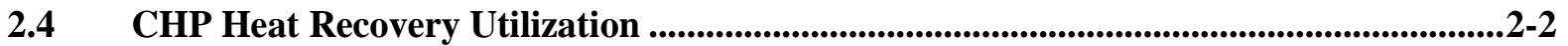

3.0 WASTE FUELS ANALYSIS ....................................................................

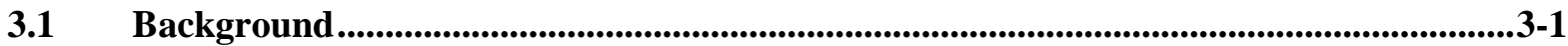

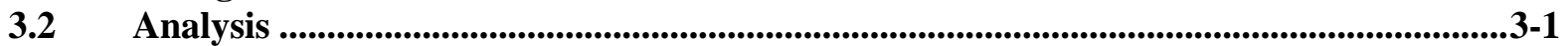

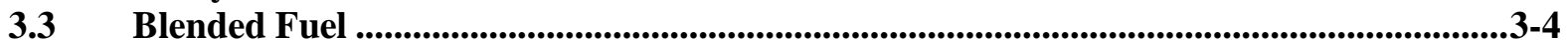

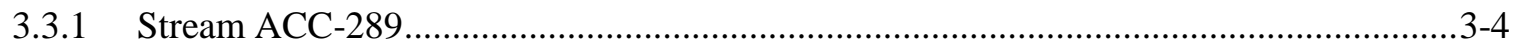

3.3.2 Blended Fuel Heating Value .........................................................................................

3.3.3 Blended Fuel Characteristics ..................................................................................

3.4 Preliminary Capital Cost Estimation .......................................................................3-10

3.5 Manufacturer Fuel Compatibility Opinions ................................................................................3-12

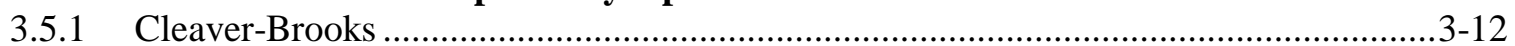

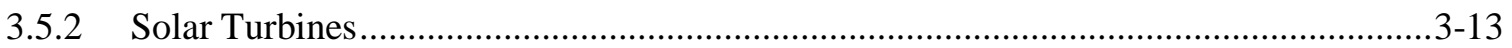

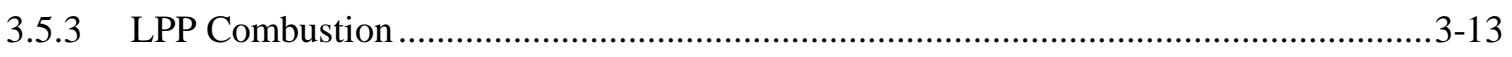

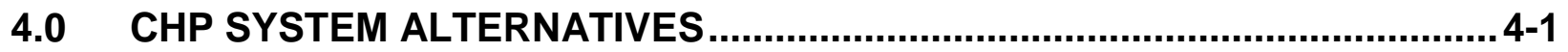

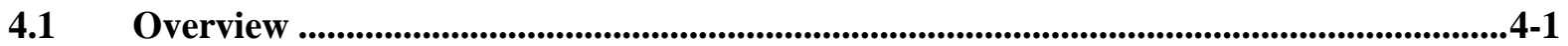

4.2 Option 1 - Single CHP Plant With Combustion Turbine.....................................................4-1

4.3 Option 2 - Single CHP Plant With Microturbines...................................................................4-2

4.4 Option 3 - Single CHP Plant With Reciprocating Engines ..................................................4-2

4.5 CHP Plant Configuration Summary .............................................................................................4-2

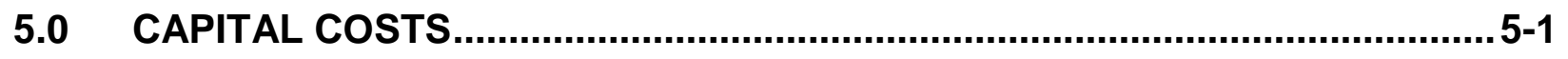

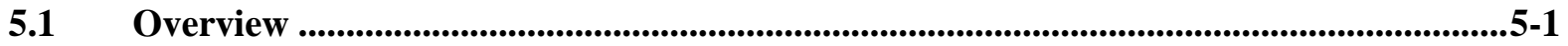

5.2 Option 1 - Single CHP Plant With Combustion Turbine.......................................................5-1

5.3 Option 2 - Single CHP Plant With Microturbines.........................................................5-2

5.4 Option 3 - Single CHP Plant With Reciprocating Engines ..............................................5-2

6.0 OPERATION AND MAINTENANCE COSTS ............................................... 6-1 


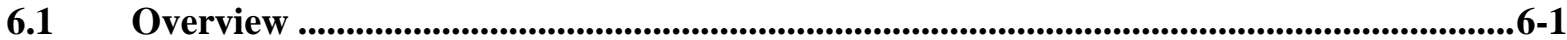

6.2 Option 1 - Single CHP Plant With Combustion Turbine....................................................6-1

6.3 Option 2 - Single CHP Plant with Microturbines..................................................................66-1

6.4 Option 3 - Single CHP Plant With Reciprocating Engines ................................................6-1

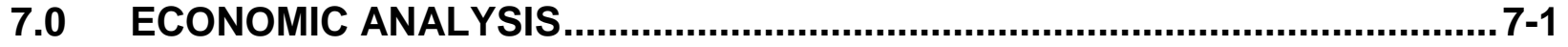

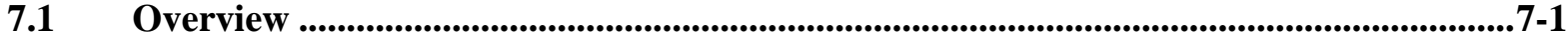

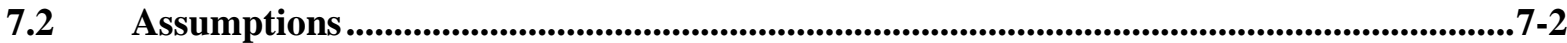

7.3 Summary of Economic Analyses................................................................................................7-3

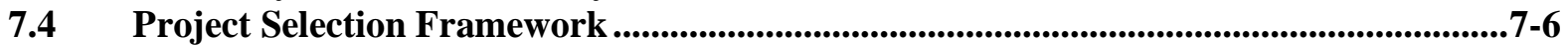

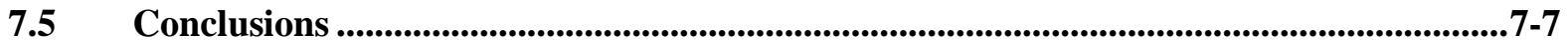

APPENDICES:

APPENDIX A - PROCESS FLOW DIAGRAMS

APPENDIX B - FINANCIAL MODELING RESULTS

APPENDIIX C- AMPAC CHEMICAL BYPRODUCT STREAMS 


\section{LIST OF TABLES}

Table ES-1: CHP Plant Configurations Assumptions. ES-4

Table ES-2: CHP Plant Configurations - 2012 Leveraged Net Present Value Summary ES-5

Table ES-3: CHP Plant Configurations - 2012 Unleveraged Net Present Value Summary. ES-5

Table ES-4: Scoring Matrix - Leveraged NPV ES-5

Table 1-1: Summary of Existing Boilers $1-1$

Table 3-1 Annual Waste Fuel Quantities by Stream.............................................................................

Table 3-2 Blended Fuel Constituent Streams …................................................................................... $3-4$

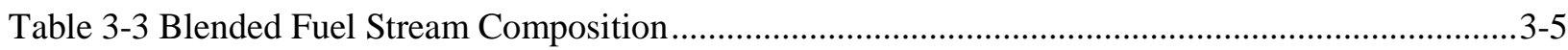

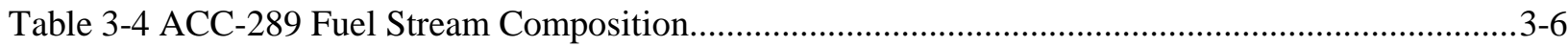

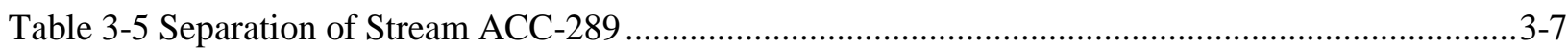

Table 3-6 Heating Value Calculation for Acetone...................................................................................

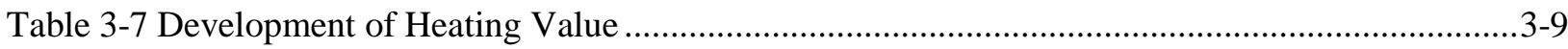

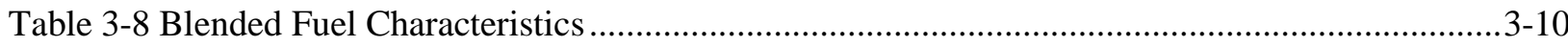

Table 3-8 Waste to Fuel System Capital Cost Estimates......................................................................3-11

Table 3-9 Capital Cost Estimates Including Vaporizer Equipment ........................................................3-12

Table 4-1: CHP Plant Configurations - Performance Assumptions.........................................................4-3

Table 7-1: CHP Plant Options - Annual Operating Revenues and Expenses ..........................................7-3

Table 7-2: CHP Plant Options - 2014 NPV Life Cycle Costs................................................................. 7-4

Table 7-3: CHP Plant Configurations -Unleveraged Indicators .............................................................. 7-5

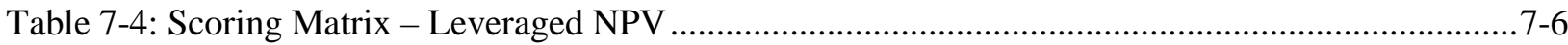

Table 7-5: Scoring Matrix - Unleveraged NPV ...................................................................................7-7

\section{LIST OF FIGURES}

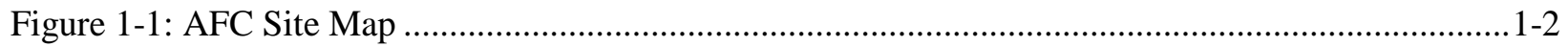

Figure 2-1: Monthly Electric Demands - Total Site.........................................................................

Figure 3-1: Blended Fuel Stream Block Flow Diagram ......................................................................3-3

Figure 7-1: CHP Plant Project Business Model...................................................................................... 
EXECUTIVE S UMMARY 


\section{EXECUTIVE SUMMARY}

\section{SUMMARY}

The U.S. Department of Energy/National Energy Technology Laboratory (U.S. DOE/NETL), AMPAC Fine Chemicals (AFC) and Sacramento Municipal Utility District (SMUD) retained Burns \& McDonnell to determine the technical and economic feasibility of recovering industrial chemical by product into fuel for a Combined Heat and Power (CHP) Plant. The assessment considers the design, installation and operation of the required fuel processing system and a CHP plant at AFC's existing pharmaceutical plant located in Folsom, CA. The installation of these systems would allow electricity to be generated from the byproduct fuel stream and consumed on-site via a prime mover technology such as a gas fired combustion turbine generator, while the exhaust heat from the prime mover is used for steam production in a heat recovery steam generator (HRSG). The steam and electricity generated in the CHP plant would reduce AFC's need to operate the existing gas fired boilers and minimize grid electric purchases from SMUD while minimizing the economic and environmental impact of chemical byproduct disposal. This would reduce AFC's total annual operating costs while offering both financial and environmental benefits to both SMUD and AFC.

\section{OBJECTIVE}

The objective of this study was to perform a technical and economic evaluation of using AMPAC's chemical byproducts as fuel for a CHP plant to serve the steam and electrical requirements of AFC's pharmaceutical manufacturing operations in Folsom, CA. AFC currently operates three distributed steam boiler plants to meet its needs. This study identified the fuel byproduct recovery process and associated equipment along with applicable CHP prime mover technology and then evaluated the overall economic performance obtained from building, owning, and operating the systems to serve AFC operations.

\section{APPROACH}

Burns \& McDonnell's approach to completing the Study included the following major activities in order to identify, evaluate, and select a recommended CHP configuration and equipment technology for AFC's site utility needs.

1. Assessment of industrial process-byproducts at the selected site to determine suitability for use as a fuel source in an on-site energy system. 
2. Assessment of requirements for industrial process-byproduct treatment and conversion into a usable fuel source.

3. Assessment of ability to use process-byproduct fuel in selected turbine, engine and boiler applications.

4. Assessment of issues related to process-byproduct fuel storage and handling equipment for delivering fuel to an on-site energy system.

5. Assessment of emission control requirements.

6. Assessment of capital cost, operation and maintenance (O\&M) cost, and life-cycle cost for the process-byproduct conversion equipment and on-site energy system.

7. Assessment of control system requirements for the on-site energy system.

8. Preparation of preliminary heat and material balance and a process flow diagram (PFD) for a process-byproduct fueled on-site energy system.

9. Evaluate and analyze the existing base case AFC site and utility plant equipment in order to determine potential locations and configurations for the proposed CHP plants.

10. Evaluate and analyze the existing base case AFC site heating loads, electric loads, and utility costs.

11. Identify the best CHP prime mover technologies based on the existing heating and electric loads and the available byproduct fuel stream.

12. Select the best CHP prime mover technologies for each of the following proposed configurations:

a. A single new central CHP plant located at the south site which would be sized to serve the total AFC minimum thermal load of $12,500 \mathrm{lb} / \mathrm{hr}$. This would require the addition of new steam and condensate lines to connect the north site and south site systems.

b. A single new central CHP plant located at the south site utilizing microturbines sized to serve as much of the minimum thermal load as possible. No site interconnection steam piping required.

c. A single new central CHP plant located at the south site utilizing reciprocating engines sized to serve as much of the minimum thermal load as possible. No site interconnection steam piping required.

13. Develop performance estimates and general process flow diagrams for each of the proposed configurations.

14. Develop capital cost estimates for each of the proposed configurations.

15. Develop annual operation and maintenance costs for each of the proposed configurations.

16. Evaluate the economics of each proposed CHP configurations. 


\section{ANALYSIS}

Burns \& McDonnell obtained the byproduct stream components and annual quantities from AFC. The chemicals were analyzed to determine heating value, combustibility and contaminants present. The byproducts that provided promising fuel characteristics were identified and the process requirements for converting them into acceptable fuels were developed. The byproduct fuel characteristics were provided to a fuel process equipment, a combustion turbine and an industrial boiler burner manufacturer to solicit an opinion on the compatibility of the byproduct fuels with the manufacturer's technology. Based on the resulting information, the available byproduct fuel quantities and the facility utility loads, CHP prime movers were selected for consideration. In each of the configurations considered, the waste heat recovered from the prime mover's exhaust would be used to meet as much of the minimum thermal load for the site under consideration as possible. Detailed descriptions for each of the fuel byproduct process equipment and the CHP configurations are presented in Section 4 of this report. A summary of each configuration's technical performance assumptions, project capital costs and operation and maintenance cost assumptions is presented in Table ES-1.

\section{RESULTS}

Burns \& McDonnell prepared an economic analysis of each of the proposed CHP configurations to determine which one provided the highest net present value (NPV) benefit. The analysis assumed that AFC would own and operate the CHP plant. When compared with the existing facility, the CHP plant would provide benefits related to steam, electricity, and chemical waste disposal costs to offset the capital cost and operating cost of the project. The steam sales would be in the form of a reduction in the amount of steam generated by natural gas fired boilers or a natural gas offset. The electric sales would be in the form of a reduction in electricity purchased from Aerojet. Depending on the scenario, electric sales to SMUD's grid would also be available when the CHP plant generated more electricity than AFC required. The waste-to-fuel capabilities of the proposed plant are estimated to significantly reduce the volume of chemical byproducts, thereby substantially mitigating waste disposal costs. Burns \& McDonnell assumed that AFC would fund the capital cost of the project with 100 percent debt financing and a 10 percent federal investment tax credit. Burns \& McDonnell summarized the results of the economic analysis in the form of pro forma cash flow statements. The NPV summary of the options is presented in Table ES-2. 
Table ES-1: CHP Plant Configurations Assumptions

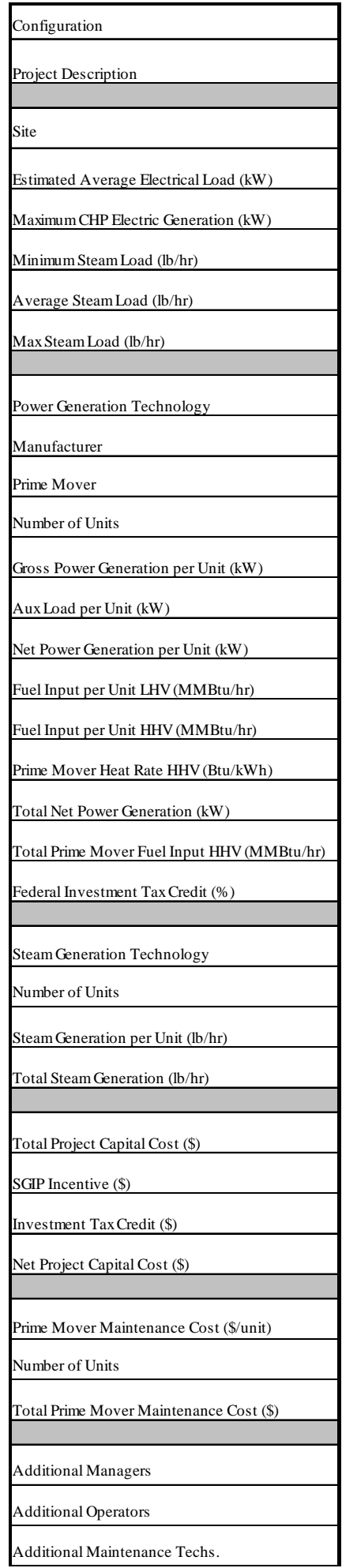

\begin{tabular}{|c|c|c|}
\hline \multicolumn{3}{|c|}{ Option 1} \\
\hline \multicolumn{3}{|c|}{$\begin{array}{l}\text { Single CHP Plant Located at South Site - } \\
\text { Supplying Steam to North and South Sites }\end{array}$} \\
\hline North Site & South Site & Total \\
\hline 1,500 & 1,500 & 3,000 \\
\hline 5,000 & 5,000 & 5,000 \\
\hline$\underline{5,500}$ & $\underline{7,000}$ & 12,500 \\
\hline 8,000 & 15,000 & 23,000 \\
\hline 12,000 & 25,000 & 37,000 \\
\hline & Combustion & Combustion \\
\hline & $\begin{array}{c}\text { Solar } \\
\end{array}$ & $\begin{array}{c}\text { Solar } \\
\text { Surnes }\end{array}$ \\
\hline & Mercury 50 & Mercury 50 \\
\hline & 1 & 1 \\
\hline & 4,419 & 4,419 \\
\hline & -40 & -40 \\
\hline & 4,379 & 4,379 \\
\hline & 40.10 & 40.10 \\
\hline & 44.11 & 44.11 \\
\hline & 10,073 & 10,073 \\
\hline & 4,379 & 4,379 \\
\hline & 44.1 & 44.1 \\
\hline & $10 \%$ & $10 \%$ \\
\hline & HRSG & HRSG \\
\hline & 1 & 1 \\
\hline & 14,376 & 14,376 \\
\hline & 14,376 & 14,376 \\
\hline & $\$ 16,488,500$ & $\$ 16,488,500$ \\
\hline & $\$ \quad(875,000)$ & $\$ \quad(875,000)$ \\
\hline & $\$(1,648,900)$ & $\$(1,648,900)$ \\
\hline & $\$ 13,964,600$ & $\$ 13,964,600$ \\
\hline & \$ $\quad 430,900$ & \$ $\quad 430,900$ \\
\hline & 1 & 1 \\
\hline & $\$ \quad 430,900$ & $\$ \quad 430,900$ \\
\hline & 0 & 0 \\
\hline & 0 & 0 \\
\hline & 1 & 1 \\
\hline
\end{tabular}

\begin{tabular}{|c|c|c|}
\hline & Option 2 & \\
\hline $\begin{array}{r}\text { Single CHP P } \\
\text { St }\end{array}$ & $\begin{array}{l}\text { ant Located at S } \\
\text { am Interconnect }\end{array}$ & $\begin{array}{l}\text { puth Site - No } \\
\text { on }\end{array}$ \\
\hline North Site & South Site & Total \\
\hline & 1,500 & 1,500 \\
\hline & 5,000 & 5,000 \\
\hline & 7,000 & 7,000 \\
\hline & 15,000 & 15,000 \\
\hline & 25,000 & 25,000 \\
\hline & Microturbine & Microturbine \\
\hline & Capstone & Capstone \\
\hline & $\mathrm{C} 200 \times 9$ & $\mathrm{C} 200 \times 9$ \\
\hline & 1 & 1 \\
\hline & 1,800 & 1,800 \\
\hline & -36 & -36 \\
\hline & 1,764 & 1,764 \\
\hline & 17.00 & 17.00 \\
\hline & 18.70 & 18.70 \\
\hline & 10,601 & 10,601 \\
\hline & 1,764 & 1,764 \\
\hline & 18.7 & 18.7 \\
\hline & $10 \%$ & $10 \%$ \\
\hline & HRSG & HRSG \\
\hline & 1 & 1 \\
\hline & 6,300 & 6,300 \\
\hline & 6,300 & 6,300 \\
\hline & $\$ 11,972,800$ & $\$ 11,972,800$ \\
\hline & $\$ \quad(691,000)$ & $\$ \quad(691,000)$ \\
\hline & $\$(1,197,300)$ & $\$(1,197,300)$ \\
\hline & $\$ 10,084,500$ & $\$ 10,084,500$ \\
\hline & $\$ \quad 301,500$ & $\$ \quad 301,500$ \\
\hline & 1 & 1 \\
\hline & $\$ \quad 301,500$ & $\$ \quad 301,500$ \\
\hline & 0 & 0 \\
\hline & 0 & 0 \\
\hline & 1 & 1 \\
\hline
\end{tabular}

\begin{tabular}{|c|c|c|}
\hline \multicolumn{3}{|c|}{ Option 3} \\
\hline \multicolumn{3}{|c|}{$\begin{array}{c}\text { Single CHP Plant Located at South Site - No } \\
\text { Steam Interconnection }\end{array}$} \\
\hline North Site & South Site & Total \\
\hline & 1,500 & 1,500 \\
\hline & 5,000 & 5,000 \\
\hline & 7,000 & 7,000 \\
\hline & 15,000 & 15,000 \\
\hline & 25,000 & 25,000 \\
\hline & & \\
\hline & $\begin{array}{l}\text { Reciprocating } \\
\text { Engine }\end{array}$ & $\begin{array}{l}\text { Reciprocating } \\
\text { Engine }\end{array}$ \\
\hline & GE & GE \\
\hline & $\begin{array}{c}\text { Jenbacher } \\
\text { JMS } 416\end{array}$ & $\begin{array}{l}\text { Jenbacher } \\
\text { JMS } 416\end{array}$ \\
\hline & 2 & 2 \\
\hline & 1,137 & 1,137 \\
\hline & -23 & -23 \\
\hline & 1,114 & 1,114 \\
\hline & 9.78 & 9.78 \\
\hline & 10.75 & 10.75 \\
\hline & 9,651 & 9,651 \\
\hline & 2,229 & 2,229 \\
\hline & 21.5 & 21.5 \\
\hline & $10 \%$ & $10 \%$ \\
\hline & HRSG & HRSG \\
\hline & 2 & 2 \\
\hline & 2,231 & 2,231 \\
\hline & 4,462 & 4,462 \\
\hline & $\$ 10,032,100$ & $\$ 10,032,100$ \\
\hline & $\$ \quad(529,100)$ & $\$ \quad(529,100)$ \\
\hline & $\$(1,003,200)$ & $\$(1,003,200)$ \\
\hline & $\$ \quad 8,499,800$ & $\$ \quad 8,499,800$ \\
\hline & $\$ \quad 137,100$ & $\$ \quad 137,100$ \\
\hline & 2 & 2 \\
\hline & $\$ \quad 274,200$ & $\$ \quad 274,200$ \\
\hline & 0 & 0 \\
\hline & 0 & 0 \\
\hline & 1 & 1 \\
\hline
\end{tabular}


Table ES-2: CHP Plant Configurations - 2012 Leveraged Net Present Value Summary

Option 1

Combustion Turbine
Option 2

Microturbines
Option 3

Reciprocating Engines
Total Net Cash Flow

Discount Rate
$\$$
$12,874,100 \quad \$$

$15.00 \%$
$13,939,700$

$15.00 \%$

Burns \& McDonnell also examined the options from an unleveraged position, assuming the projects were funded through equity rather than debt. This approach eliminates some economic distortion that can result when examining leveraged NPVs. The unleveraged results are presented in Table ES-3.

Table ES-3: CHP Plant Configurations - 2012 Unleveraged Net Present Value Summary

Option 1

Combustion Turbine
Option 2

Microturbines
Option 3

Reciprocating Engines

$\$$

$8,855,900$
3 Years 5 Mos
$17.61 \%$
3 Years 2 Mos
$18.14 \%$

9,888,600

2 Years 9 Mos

$19.18 \%$

Modified Internal Rate of Return (MIRR)

As noted in Tables ES-2 and ES-3, all options are anticipated to create substantial economic value to AFC. The precise ranking of the options depends on whether or not debt or equity funding is considered in the NPV analysis. However, in determining which project(s) merit further diligence and development, factors beyond economic results may be considered. These factors are described in Section 7 of this report. Table ES-4 scores projects on the basis of economic results, risk, and other factors.

\section{Table ES-4: Scoring Matrix - Leveraged NPV}

\begin{tabular}{|c|c|c|c|c|c|c|c|}
\hline Metric & $\begin{array}{c}\text { Leveraged } \\
\text { Economic } \\
\text { Assessment }\end{array}$ & $\begin{array}{c}\text { Proven } \\
\text { Technology }\end{array}$ & $\begin{array}{l}\text { Regulatory } \\
\text { Incentives }\end{array}$ & $\begin{array}{c}\text { Environmental } \\
\text { Permitting }\end{array}$ & $\begin{array}{c}\text { Commodity } \\
\text { Pricing } \\
\end{array}$ & $\begin{array}{c}\text { Power } \\
\text { Reliability }\end{array}$ & Score \\
\hline Maximum Potential Score & 10 & 5 & 5 & 5 & 5 & 5 & 35 \\
\hline Option 1: Combustion Turbine & 10 & 3 & 3 & 4 & 3 & 5 & 28 \\
\hline Option 2: Microturbine & 8 & 5 & 5 & 4 & 5 & 3 & 30 \\
\hline Option 3: Reciprocating Engine & 9 & 3 & 5 & 3 & 5 & 3 & 28 \\
\hline
\end{tabular}

Based on the scoring matrix presented in Table ES-4, Option 2 with the Capstone microturbines offers the best balance of economic value, risk, and other less tangible factors, and merits further diligence and development. 


\section{STATEMENT OF LIMITATIONS}

In completing this study, information provided by AFC, SMUD and other sources was utilized by Burns \& McDonnell to make certain assumptions with respect to conditions that may exist in the future. While Burns \& McDonnell believes the assumptions made are reasonable for the purposes of this study, no representation is made that the conditions assumed will, in fact, occur. In addition, while Burns \& McDonnell has no reason to believe that the information provided by AFC, SMUD and other parties, and on which Burns \& McDonnell has relied, is inaccurate in any material respect, Burns \& McDonnell has not independently verified such information and cannot guarantee its accuracy or completeness. To the extent that actual future conditions differ from those assumed herein or from the information provided by AFC, SMUD, and other parties the actual results will vary from those projected. 
SECTION 1.0 DESCRIPTION OF EXIS TING PLANT 


\subsection{DESCRIPTION OF EXISTING PLANT}

The AMPAC Fine Chemical (AFC) facility is an industrial pharmaceutical manufacturing plant located in Folsom, CA. The campus is grouped into two areas divided by a road, and a vacant area with a number of trees. The south site is supplied with steam from four boilers located in Building 5067. The north site is supplied with steam from four boilers located in Building 5026 and one boiler located in Building 5061. A general summary of the existing boilers is provided in Table 1-1.

Table 1-1: Summary of Existing Boilers

North Site Boilers

\begin{tabular}{|c|c|c|c|c|c|c|}
\hline Bldg No. & Boiler No. & Make & $\begin{array}{c}\text { Low Nox } \\
\text { Retrofit }\end{array}$ & Primary Fuel & $\begin{array}{c}\text { Secondary } \\
\text { Fuel }\end{array}$ & $\begin{array}{c}\text { Capacity } \\
\text { (MMBtu) }\end{array}$ \\
\hline 5026 & 3 & Cleaver Brooks & Completed & natural gas & propane & 3.36 \\
\hline 5026 & 4 & Cleaver Brooks & Completed & natural gas & propane & 3.36 \\
\hline 5026 & 5 & Cleaver Brooks & Completed & natural gas & propane & 3.36 \\
\hline 5026 & 6 & Husky & 2009 & natural gas & propane & 6.30 \\
\hline 5061 & & Abco & N/A & natural gas & propane & 1.26 \\
\hline
\end{tabular}

Total North Site Capacity

17.64

South Site Boilers

\begin{tabular}{|c|c|c|c|c|c|c|}
\hline Bldg No. & Boiler No. & Make & $\begin{array}{c}\text { Low Nox } \\
\text { Retrofit }\end{array}$ & Primary Fuel & $\begin{array}{c}\text { Secondary } \\
\text { Fuel }\end{array}$ & $\begin{array}{c}\text { Capacity } \\
\text { (MMBtu) }\end{array}$ \\
\hline 5067 & 1 & Cleaver Brooks & Completed & natural gas & diesel & 12.60 \\
\hline 5067 & 2 & Cleaver Brooks & 2009 & natural gas & none & 8.37 \\
\hline 5067 & 3 & Abco & Completed & natural gas & diesel & 8.60 \\
\hline \multicolumn{6}{c|}{ Total South Site Capacity } & $\mathbf{2 9 . 5 7}$ \\
Total AFC Steam Capacity
\end{tabular}

AFC staff provided Burns \& McDonnell with an aerial photo of the existing AFC campus which indicated where the existing boilers and steam lines were located. Burns \& McDonnell reviewed the site and identified two potential sites where a new CHP plant could be located. In addition, if AFC decides to install one CHP plant at the south site, a new steam pipeline and new condensate return pipeline would be required to connect the two existing steam distribution systems. A map showing the location of the existing boilers, existing steam distribution systems, the potential CHP plant sites, and the potential pipeline routing to connect to the north and south sites is presented in Figure 1-1. 
Figure 1-1: AFC Site Map

$* * * * *$

Burns \&

McDonnell 
SECTION 2.0

SITE ENERGY REQUIREMENTS 


\subsection{SITE ENERGY REQUIREMENTS}

\subsection{OVERVIEW}

The existing AFC complex is divided into a north site and south site. The following section provides an overview of the thermal and electrical loads at each of the sites and the development of the load data which was used to size the proposed CHP configurations.

\subsection{ELECTRIC LOADS}

AFC currently purchases electricity for the north and south sites through Aerojet. Aerojet purchases electricity from SMUD and then resells it to AFC at the same retail rate. AFC provided Burns \& McDonnell the historical electricity consumption data for the last four years. Burns \& McDonnell then calculated the estimated maximum, average and minimum daily load data for each month so that an hourly electric load shape could be developed. The load shape was used to determine when the proposed CHP plant would off-set existing site electric load at the current retail electric rates and when the CHP plant would export energy back to SMUD at the feed-in-tariff (FIT) rates.

Figure 2-1: Monthly Electric Demands - Total Site

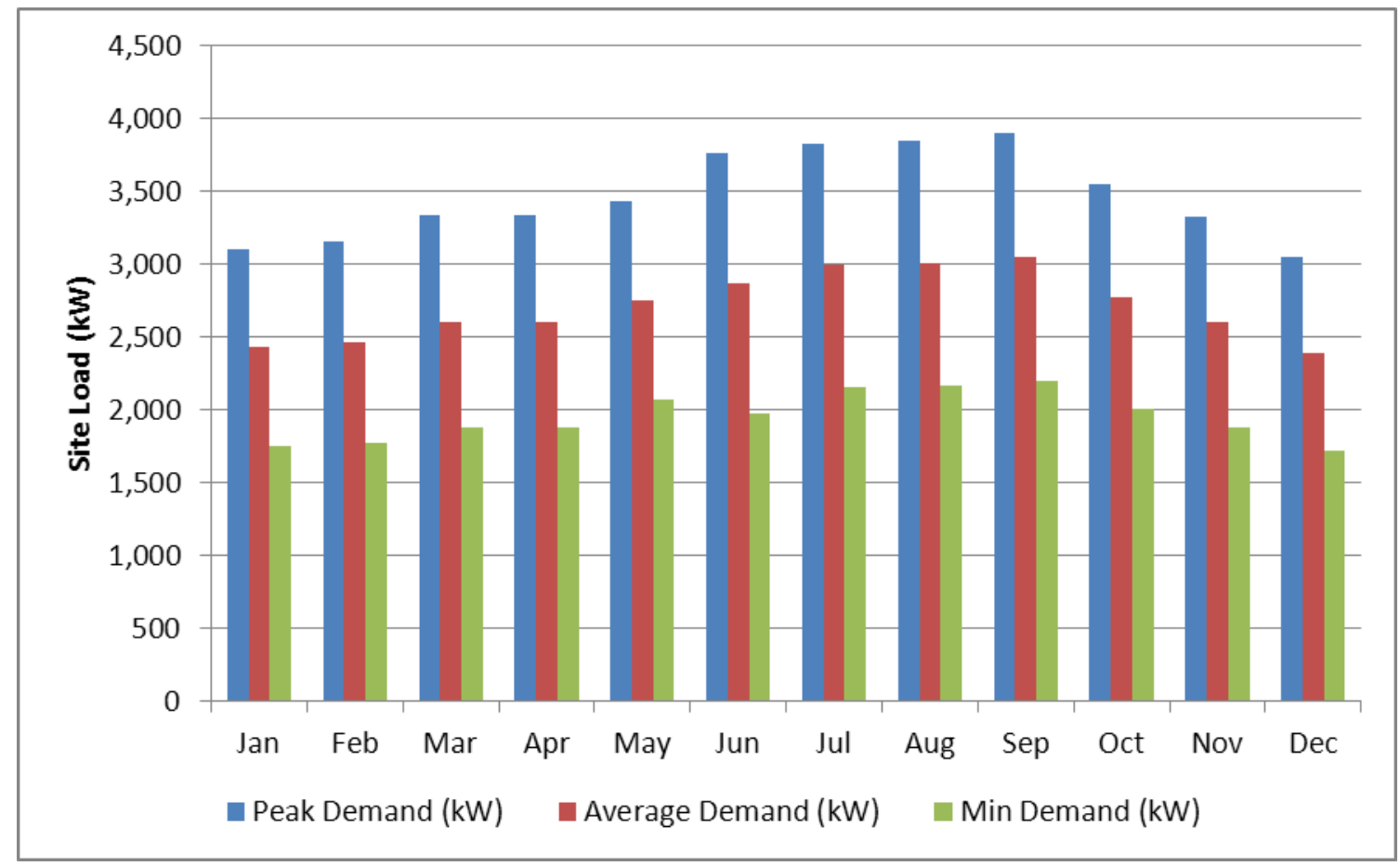




\subsection{STEAM LOADS}

Currently, the north and south steam distribution systems are not connected and they operate independently. Steam is supplied to the north site by the two existing boiler houses located on the north site which are each comprised of several existing gas fired boilers. These boilers are connected through the north site steam supply distribution system and condensate return system and are sized to meet the maximum thermal needs of the north site. Steam supplied to the south site is generated by a single boiler house located on the south site which is comprised of several individual gas fired boilers and is sized to meet the maximum thermal needs of the south site. The steam is distributed to the various buildings by an existing steam distribution system with no condensate return system. AFC provided historical monthly natural gas usage data for each of the boilers along with estimated minimum, average and peak steam loads at each site. The minimum steam load data at each site was used to size the CHP configurations developed in this study. A summary of the estimated minimum, average and maximum monthly steam demand data provided by AFC is provided below.

$\begin{array}{llll} & \text { North } & \underline{\text { South }} & \text { Total } \\ \text { Minimum Steam Load (lbs/hr) } & 5,500 & 7,000 & 12,500 \\ \text { Average Steam Load (lbs/hr) } & 8,000 & 15,000 & 23,000 \\ \text { Maximum Steam Load (lbs/hr) } & 12,000 & 25,000 & 37,000\end{array}$

\subsection{CHP HEAT RECOVERY UTILIZATION}

In the development of the Burns \& McDonnell February 2010 report, SMUD and AFC requested that Burns \& McDonnell evaluate several CHP configurations. In this update, the addition of the waste to fuel capability was evaluated along the following CHP configurations:

1. A single new CHP plant located at the south site sized to serve the total AFC minimum thermal load of 12,500 lb/hr. This would require the addition of new steam and condensate lines to connect the north and south site systems.

2. A single new CHP plant located at the south site utilizing microturbines which would be sized to serve the south site's minimum thermal load of 7,000 lbs/hr. No site interconnection would be required.

3. A single new CHP plant located at the south site utilizing reciprocating engines which would be sized to serve the south site's minimum thermal load of 7,000 lbs/hr. No site interconnection would be required. 
SECTION 3.0

WAS TE FUELS ANALYSIS 


\subsection{WASTE FUELS ANALYSIS}

\subsection{BACKGROUND}

Burns \& McDonnell obtained the byproduct stream components and annual quantities from AFC. The chemicals were analyzed to determine heating value, combustibility and contaminants present. The byproducts that provided promising fuel characteristics were identified and the process requirements for converting them into acceptable fuels were developed. The byproduct fuel characteristics were provided to three vendors to solicit opinions on the compatibility of the byproduct fuels with their technology. Based on the resulting information, the available byproduct fuel quantities were established.

\subsection{ANALYSIS}

Based on information provided by AMPAC, 3,572,000 kg of solvent wastes are produced that have the potential be utilized as fuels. Of this waste stream, 3,424,000 kg (96 percent) are combustible hydrocarbon compounds containing carbon, hydrogen, oxygen and nitrogen atoms. The remaining $148,000 \mathrm{~kg}$ (4 percent) are various compounds that contain other atoms. The other compounds may be unsuitable for combustion either because they may inhibit the combustion reaction or produce potentially corrosive by-products. Examples of these contaminant compounds include Methylene Chloride, Chloromethyl-2propylcarbonate and compounds containing Bromine. Stream ACC 340.2 which primarily contains Methylene Chloride (68 percent) is not considered to be a suitable fuel and should be segregated from the potential waste fuel streams. Stream ACC-340.2 should not be blended with the other streams to be utilized as fuel. Sixteen percent of stream ACC-288 is made up of Bromine compounds. Stream ACC-288 should be partially segregated, physically at the source, to eliminate Ethyl Bromide and t-butylbromide from the fuel stream. The remainder of ACC-288 should be suitable as a fuel. The streams that are suitable as fuel and their annual quantities are shown in Table 3-1.

Some of the streams contain components that are less suitable for combustion but are a small percentage of the stream (typically less than 1 percent). On a first analysis basis, these smaller components do not pose sufficient risk to warrant a separation scheme. The streams identified with a check mark have trace components that will likely have products of combustion other than $\mathrm{CO}_{2}$ and $\mathrm{H}_{2} \mathrm{O}$. ACC-308/324 contains 1 percent Sodium Methoxide. ACC-268 contains 1 percent Methanesulfonic Acid. However, in a blended fuel stream, the impact on combustion and combustion by-products is expected to be minimal. ACC-289 contains 3 percent Chloromethyl-2propylcarbonate and the effect of chlorine during combustion may be detrimental. The largest contaminant in a blend of all waste fuel streams would be Chloromethyl-2propylcarbonate, at 2 percent, coming from stream ACC-289. Stream ACC-289 was 
evaluated for a separation unit operation (distillation) to eliminate most of Chloromethyl2propylcarbonate prior to blending with other waste streams and being used as a fuel.

Table 3-1 Annual Waste Fuel Quantities by Stream

\begin{tabular}{|l|r|c|}
\hline Fuel Stream & Quantity (kg) & $\begin{array}{c}\text { Streams With Trace } \\
\text { Components }\end{array}$ \\
\hline ACC-261/278, ACC-321/322 & 9,116 & \\
\hline ACC-308/324 & 121,627 & $\checkmark$ \\
\hline ACC-262/322 & 697,382 & $\checkmark$ \\
\hline ACC-289 & $1,948,036$ & $\checkmark$ \\
\hline $\begin{array}{l}\text { ACC-288 (after Bromine compound } \\
\text { segregation) }\end{array}$ & 197,686 & $\checkmark$ \\
\hline ACC-268 & 530,166 & \\
\hline ACC-342.3 & 18,315 & \\
\hline ACC-342.2 & 10,397 & \\
\hline ACC-342.1 & 8,004 & \\
\hline ACC-341/343 & 1,793 & \\
\hline ACC-340.1 & 18,351 & \\
\hline ACC-340 & 11,511 & \\
\hline
\end{tabular}

A block flow diagram of the proposed approach to creating a blended fuel stream is shown on the following page in Figure 3-1. The elements of the strategy include modifying reactor exit piping, valves and controls to allow segregation within recipes as well as from individual reactors. Separable waste is intended to be sent to distillation where the concentration of the contaminating compound is decreased to a suitable level. Material that is not suitable as a fuel is sent to Hazardous Waste Storage. In the current analysis, aqueous waste was not evaluated. The objective of this approach is to provide a continuous fuel stream to a CHP combustion device. 
Figure 3-1: Blended Fuel Stream Block Flow Diagram

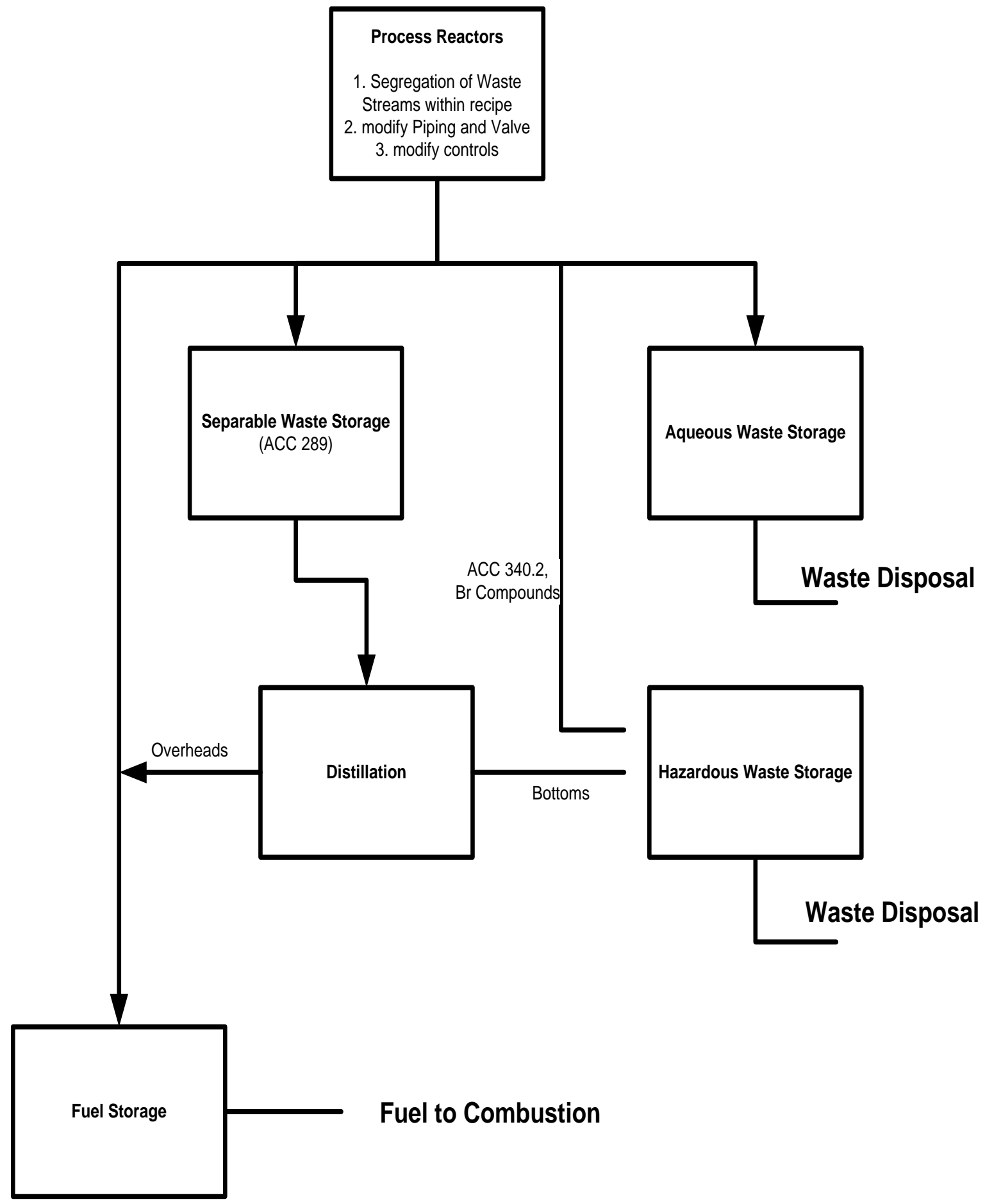




\subsection{BLENDED FUEL}

The composition of the blended fuel was estimated by assuming that the projected number of batches per year for each product (stream) was evenly distributed throughout the year and that one to two months of waste fuel storage capacity would be available. The fuel being provided to the CHP device was assumed to have been blended from the constituent number of batches for each stream as shown in Table 3-2 below. The estimated blended fuel stream composition shown in Table 3-3 represents 98.35 percent of stream. The other 1.65 percent consists of several hydrocarbon components of a proprietary nature and various components making up less than 0.1 percent of the stream.

Table 3-2 Blended Fuel Constituent Streams

\begin{tabular}{|l|c|c|}
\hline Description & Batches/Yr. & Batches/Mo. \\
\hline ACC-261/278, ACC-321/322 & 212 & 17 \\
\hline ACC-308/324 & 48 & 4 \\
\hline ACC-262/322 & 127 & 10 \\
\hline ACC-289 & 113 & 9 \\
\hline ACC-288 & 57 & 4 \\
\hline ACC-268 & 59 & 4 \\
\hline ACC-342.3 & 6 & 0.5 \\
\hline ACC-342.2 & 6 & 0.5 \\
\hline ACC-342.1 & 6 & 0.5 \\
\hline ACC-341/343 & 9 & 0.7 \\
\hline ACC-340.1 & 3 & 0.2 \\
\hline ACC-340 & 3 & 0.2 \\
\hline
\end{tabular}

\subsubsection{Stream ACC-289}

Stream ACC-289 represents over 50 percent of the annual quantity of solvent waste generated. However, the stream contains 3 percent Chloromethyl-2propylcarbonate. This chlorinated compound could be detrimental in a combustion process due to inhibition of combustion reactions and generation of potentially corrosive chlorine compounds. As a result, it is desirable to separate out the chlorinated compound but retain the hydrocarbon components in the fuel stream. 
Table 3-3 Blended Fuel Stream Composition

\begin{tabular}{|l|c|c|c|c|}
\hline Description & Formula & MW & kg/month & Mass - \% \\
\hline Acetone & $\mathrm{C}_{3} \mathrm{H}_{6} \mathrm{O}$ & 58.08 & 85,098 & $31.37 \%$ \\
\hline Acetonitrile & $\mathrm{C}_{2} \mathrm{H}_{3} \mathrm{~N}$ & 41.05 & 368 & $0.14 \%$ \\
\hline Butanol & $\mathrm{C}_{4} \mathrm{H}_{10} \mathrm{O}$ & 74.12 & 274 & $0.10 \%$ \\
\hline Chloromethyl-2propylcarbonate & $\mathrm{C}_{5} \mathrm{H}_{9} \mathrm{ClO}_{3}$ & 152.58 & 520 & $0.19 \%$ \\
\hline Dimethylformamide & $\mathrm{C}_{3} \mathrm{H}_{7} \mathrm{NO}$ & 73.09 & 12,117 & $4.47 \%$ \\
\hline Ethyl Acetate & $\mathrm{C}_{2} \mathrm{H}_{6} \mathrm{O}$ & 46.07 & 8,222 & $3.03 \%$ \\
\hline Fumaric Acid & $\mathrm{C}_{4} \mathrm{H}_{8} \mathrm{O}_{2}$ & 88.11 & 5,354 & $1.97 \%$ \\
\hline Heptane & $\mathrm{C}_{4} \mathrm{H}_{4} \mathrm{O}_{4}$ & 116.07 & 792 & $0.29 \%$ \\
\hline Isopropyl alcohol & $\mathrm{C}_{7} \mathrm{H}_{16}$ & 100.21 & 707 & $0.26 \%$ \\
\hline Isopropyl Acetate & $\mathrm{C}_{3} \mathrm{H}_{8} \mathrm{O}$ & 60.1 & 20,596 & $7.59 \%$ \\
\hline IsoPropyl Ether & $\mathrm{C}_{5} \mathrm{H}_{10} \mathrm{O}_{2}$ & 102.13 & 22,803 & $8.41 \%$ \\
\hline Methanesulfonic Acid & $\mathrm{C}_{6} \mathrm{H}_{14} \mathrm{O}$ & 102.18 & 59,840 & $22.06 \%$ \\
\hline Methanol & $\mathrm{CH}_{4} \mathrm{O}_{3} \mathrm{~S}$ & 96.11 & 351 & $0.13 \%$ \\
\hline MTBE, Methyl tert-butyl ether & $\mathrm{CH}_{4} \mathrm{O}$ & 32.04 & 9,722 & $3.58 \%$ \\
\hline NMP, N-Methyl-2-pyrrolidone & $\mathrm{C}_{5} \mathrm{H}_{12} \mathrm{O}$ & 88.15 & 2,073 & $0.76 \%$ \\
\hline Propylene Carbonate & $\mathrm{C}_{5} \mathrm{H}_{9} \mathrm{NO}_{2}$ & 99.13 & 18,627 & $6.87 \%$ \\
\hline TEA, triethylamine & $\mathrm{C}_{4} \mathrm{H}_{6} \mathrm{O}_{3}$ & 102.09 & 304 & $0.11 \%$ \\
\hline Toluene & $\mathrm{C}_{6} \mathrm{H}_{15} \mathrm{~N}$ & 101.19 & 2,319 & $0.85 \%$ \\
\hline Water & $\mathrm{C}_{6} \mathrm{H}_{5} \mathrm{CH}$ & 92.14 & 15,510 & $5.72 \%$ \\
\hline & & & 1,216 & $0.45 \%$ \\
\hline
\end{tabular}

Separation of the chlorinated compound from the stream using distillation was simulated in ASPEN PLUS. The composition and feed rate for an ASPEN PLUS simulation were based on the component rates listed in Table 3-4 and assuming 8,000 hours of continuous operation annually. The simulated feed stream is shown in Table 3-5. Compounds with relatively low concentrations were not modeled. ASPEN PLUS simulation using a continuous distillation tower with a condenser, a re-boiler and 30 feet of 1.5 inch packing was performed. The separation was obtained with a reflux ratio of 5 to 1 , a condenser duty of 481,000 Btu/hr. and a re-boiler duty of 512,000 Btu/hr. The estimated tower inner diameter (ID) is 18 inches and the tower height is approximately 40 feet. It was concluded that it is feasible to transform the feed stream containing 3.4 wt percent Chloromethyl-2-Propylcarbonate by continuous distillation into a distillate stream which accounts for 84.3 percent of the feed stream containing only 0.3 percent Chloromethyl-2-Propylcarbonate and a bottoms stream that is $15.7 \mathrm{wt}$ percent of the feed stream that contains 20 percent Chloromethyl-2-Propylcarbonate. It is proposed that the distillate stream can be used as fuel and the bottoms stream can be sent to hazardous waste disposal. Conceptually, the feed stream would be accumulated in storage tanks as it is produced and fed continuously to the distillation tower. 
Table 3-4 ACC-289 Fuel Stream Composition

\begin{tabular}{|l|c|c|c|l|}
\hline Description & Batch & Distribution & Annual & Comment \\
\hline & $(\mathrm{kg})$ & & $(\mathrm{kg})$ & \\
\hline Acetone & 2695 & $16 \%$ & 304,535 & Hydrocarbon, potential fuel \\
\hline Water & 33.82 & $0 \%$ & 3,822 & \\
\hline NMP & 2069.66 & $12 \%$ & 233,872 & \\
\hline TEA & 257.65 & $1 \%$ & 29,114 & \\
\hline Chloromethyl-2propylcarbonate & 577.8 & $3 \%$ & 65,291 & Must separate from stream \\
\hline Hydroxylamine & 0.27 & $0 \%$ & 31 & \\
\hline N6-Hydroxymethyl & 2.38 & $0 \%$ & 269 & \\
\hline Oxime & 3.5 & $0 \%$ & 396 & \\
\hline Ammonium Acetate & 1.3 & $0 \%$ & 147 & \\
\hline Isopropyl Acetate & 2533.71 & $15 \%$ & 286,309 & Hydrocarbon, potential fuel \\
\hline Sodium Chloride & 2.65 & $0 \%$ & 299 & \\
\hline Fumaric Acid & 88.04 & $1 \%$ & 9,949 & Hydrocarbon, potential fuel \\
\hline IPA & 2249.86 & $13 \%$ & 254,234 & Hydrocarbon, potential fuel \\
\hline PMPA-TEA Salt & 20.85 & $0 \%$ & 2,356 & \\
\hline Tenofovir DF & 53.84 & $0 \%$ & 6,084 & \\
\hline IsoPropyl Ether & 6648.93 & $39 \%$ & 751,329 & Hydrocarbon, potential fuel \\
\hline
\end{tabular}

\subsubsection{Blended Fuel Heating Value}

The heating value of the blended fuel stream was estimated to allow preliminary sizing of the CHP prime mover. The calculated heating value was determined on the basis component mass and component heating value. Initially, the heating value per gram was calculated for the component and then the total estimated mass per month was utilized to establish the available heating value per month. As an example, the heating value equation for Acetone is shown below and the heating value calculation is shown in Table 3-6.

- Acetone + Oxygen $=$ Carbon Dioxide + Water

- $\mathrm{C}_{3} \mathrm{H}_{6} \mathrm{O}+4 \mathrm{O}_{2}=3 \mathrm{CO}_{2}+3 \mathrm{H}_{2} \mathrm{O}$ 
Table 3-5 Separation of Stream ACC-289

\begin{tabular}{|c|c|c|c|}
\hline Separation of Stream ACC-289 & Feed & Overhead & Bottoms \\
\hline Temperature (F) & 70 & 142 & 392.1 \\
\hline Pressure ( psia) & 20 & 15 & 17 \\
\hline Vapor Fraction & 0 & 0 & 0 \\
\hline Mole Flow (lbmol/hr) & 6.336 & 5.55 & 0.785 \\
\hline Mass Flow $(\mathrm{lb} / \mathrm{hr})$ & 534.11 & 450 & 84.11 \\
\hline Volume Flow (cu ft/hr) & 10.387 & 9.78 & 1.481 \\
\hline \multicolumn{4}{|l|}{ Component Mass Flow (lb/hr) } \\
\hline Acetone $\left(\mathrm{C}_{3} \mathrm{H}_{6} \mathrm{O}-01\right)$ & 83.9 & 83.9 & 0 \\
\hline Water $\left(\mathrm{H}_{2} \mathrm{O}\right)$ & 1 & 1 & 0 \\
\hline NMP, N-Methyl-2-pyrrolidone $\left(\mathrm{C}_{5} \mathrm{H}_{9} \mathrm{~N}-01\right)$ & 64.6 & 0 & 64.6 \\
\hline TEA, triethylamine $\left(\mathrm{C}_{6} \mathrm{H}_{15} \mathrm{~N}-01\right)$ & 8 & 8 & 0 \\
\hline Chloromethyl-2propylcarbonate $\left(\mathrm{C}_{5} \mathrm{H}_{9} \mathrm{CLO}_{3}\right)$ & 18 & 1.19 & 16.81 \\
\hline Hydroxylamine $\left(\mathrm{H}_{3} \mathrm{NO}\right)$ & 0.01 & 0.01 & 0 \\
\hline Isopropyl Acetate $\left(\mathrm{C}_{5} \mathrm{H}_{10}-01\right)$ & 78.9 & 78.9 & 0 \\
\hline Fumaric Acid $\left(\mathrm{C}_{4} \mathrm{H}_{4} \mathrm{O}-01\right)$ & 2.7 & 0 & 2.7 \\
\hline Isopropyl Alcohol $\left(\mathrm{C}_{3} \mathrm{H}_{8} \mathrm{O}-01\right)$ & 70 & 70 & 0 \\
\hline Diisopropyl Ether $\left(\mathrm{C}_{6} \mathrm{H}_{14}-01\right)$ & 207 & 207 & 0 \\
\hline \multicolumn{4}{|l|}{ Weight \% } \\
\hline Acetone $\left(\mathrm{C}_{3} \mathrm{H}_{6} \mathrm{O}-01\right)$ & $15.70 \%$ & $18.60 \%$ & $0.00 \%$ \\
\hline Water $\left(\mathrm{H}_{2} \mathrm{O}\right)$ & $0.20 \%$ & $0.20 \%$ & $0.00 \%$ \\
\hline NMP, N-Methyl-2-pyrrolidone $\left(\mathrm{C}_{5} \mathrm{H}_{9} \mathrm{~N}-01\right)$ & $12.10 \%$ & $0.00 \%$ & $76.80 \%$ \\
\hline TEA, triethylamine $\left(\mathrm{C}_{6} \mathrm{H}_{15} \mathrm{~N}-01\right)$ & $1.50 \%$ & $1.80 \%$ & $0.00 \%$ \\
\hline Chloromethyl-2propylcarbonate $\left(\mathrm{C}_{5} \mathrm{H}_{9} \mathrm{CLO}_{3}\right)$ & $3.40 \%$ & $0.30 \%$ & $20.00 \%$ \\
\hline Hydroxylamine $\left(\mathrm{H}_{3} \mathrm{NO}\right)$ & $0.00 \%$ & $0.00 \%$ & $0.00 \%$ \\
\hline Isopropyl Acetate $\left(\mathrm{C}_{5} \mathrm{H}_{10}-01\right)$ & $14.80 \%$ & $17.50 \%$ & $0.00 \%$ \\
\hline Fumaric Acid $\left(\mathrm{C}_{4} \mathrm{H}_{4} \mathrm{O}-01\right)$ & $0.50 \%$ & $0.00 \%$ & $3.20 \%$ \\
\hline Isopropyl Alcohol $\left(\mathrm{C}_{3} \mathrm{H}_{8} \mathrm{O}-01\right)$ & $13.10 \%$ & $15.60 \%$ & $0.00 \%$ \\
\hline Diisopropyl Ether $\left(\mathrm{C}_{6} \mathrm{H}_{14}-01\right)$ & $38.80 \%$ & $46.00 \%$ & $0.00 \%$ \\
\hline
\end{tabular}


Table 3-6 Heating Value Calculation for Acetone

\begin{tabular}{|l|c|c|c|}
\hline Compound & $\begin{array}{c}\text { Heating Value } \\
\mathbf{( k J / m o l . )}\end{array}$ & Molecules & $\begin{array}{c}\text { Heating Value } \\
\mathbf{( k J} / \mathbf{m o l} .)\end{array}$ \\
\hline Acetone & -217 & 1 & -217 \\
\hline Oxygen & 0 & 4 & 0 \\
\hline Carbon Dioxide & -393 & 3 & $-1,181$ \\
\hline Water & -285 & 3 & -857 \\
\hline & & & $1,821 \mathrm{~kJ} / \mathrm{mol}$. \\
\hline Net Higher Heating Value per Molecule & & $58 \mathrm{~g} / \mathrm{mol}$. \\
\hline Molecular Weight & & $31.35 \mathrm{~kJ} / \mathrm{g}$ \\
\hline Net Higher Heating Value per mass
\end{tabular}

Acetone and Isopropyl Ether are the two largest components with 31.37 mass percentage and 22.06 mass percentage, respectively, as shown previously in Table 3-3. Other significant components include Isopropyl Acetate, Isopropyl Alcohol, N-Methyl-2-pyrrolidone and Toluene. Some of the smaller components were not included in the estimation due to their low mass percentage. In general, the gross heating value is of the same order of magnitude as that of fuel oil and maybe slightly lower. The total quantity of heat available for CHP is approximately $17 \mathrm{MMBTU} / \mathrm{Hr}$ as shown in Table 3-7.

\subsubsection{Blended Fuel Characteristics}

It is common practice to produce fuel oils that comply with certain specifications as defined by ASTM standards. Typically, fuel oils are graded according to density (specific gravity) and viscosity. The lightest fuel oil is designated as No. 1 and the heaviest being No. 6. Since equipment for handling and burning of fuel oil is usually designated for a maximum viscosity, it is necessary to know the characteristics of the fuel to be used. In addition to density and viscosity, the mass percentage of components that participate in the combustion reaction can also be compared between different fuels. A calculated gross heating value also provides a basis of comparison for different fuels. Table 3-8 provides a comparison of the blended fuel stream produced from the waste streams in the process to fuel oils No. 1 and No. 2. 
Table 3-7 Development of Heating Value

\begin{tabular}{|l|c|c|c|c|}
\hline Blended Fuel Stream & \multicolumn{4}{|c|}{ Heating Value } \\
\hline & $\mathrm{kJ} / \mathrm{g}$ & MMBtu/month & MMBtu/day & MMBtu/hour \\
\hline Acetone & 31 & 2,527 & 84 & 4 \\
\hline Butanol & 37 & 9 & 0 & 0 \\
\hline Chloromethyl-2propylcarbonate & 80 & 40 & 1 & 0 \\
\hline Dimethylformamide & 106 & 1,219 & 41 & 2 \\
\hline Ethanol & 31 & 238 & 8 & 0 \\
\hline Ethyl Acetate & 26 & 131 & 4 & 0 \\
\hline Fumaric Acid & 11 & 9 & 0 & 0 \\
\hline Heptane & 48 & 32 & 1 & 0 \\
\hline Isopropyl alcohol & 68 & 1,332 & 44 & 2 \\
\hline Isopropyl Acetate & 56 & 1,217 & 41 & 2 \\
\hline IsoPropyl Ether & 40 & 2,242 & 75 & 3 \\
\hline Methanol & 48 & 439 & 15 & 1 \\
\hline NMP, N-Methyl-2-pyrrolidone & 121 & 2,130 & 71 & 3 \\
\hline Propylene Carbonate & 0 & 0 & 0 & 0 \\
\hline TEA, triethylamine & 174 & 383 & 13 & 1 \\
\hline Toluene & 43 & 629 & 21 & 1 \\
\hline & & $\mathbf{1 2 , 5 7 8}$ & $\mathbf{4 1 9}$ & $\mathbf{1 7}$ \\
\hline
\end{tabular}

Other ASTM standard fuel characteristics such as flash point, pour point, ash content, water and sediment volume percent, distillation temperatures and copper strip corrosion can be obtained by standard laboratory measurements and can be a further basis for comparison. 
Table 3-8 Blended Fuel Characteristics

\begin{tabular}{|l|c|c|c|}
\hline \multirow{2}{*}{ Description } & \multicolumn{3}{|c|}{ Mass Percent } \\
\cline { 2 - 4 } & \multirow{2}{*}{ Fuel Blend } & \multicolumn{2}{|c|}{ Fuel Oil } \\
\cline { 3 - 4 } & & No. 1 & No.2 \\
\hline Carbon & $63.00 \%$ & $86.00 \%$ & $86.90 \%$ \\
\hline Hydrogen & $11.00 \%$ & $13.40 \%$ & $12.50 \%$ \\
\hline Oxygen & $24.00 \%$ & - & - \\
\hline Nitrogen & $2.00 \%$ & $0.10 \%$ & $0.10 \%$ \\
\hline Sulfur & $0.04 \%$ & $0.50 \%$ & $0.50 \%$ \\
\hline Chlorine & $0.05 \%$ & - & - \\
\hline Other Characteristics & & & \\
\hline Density (lb/ft3) & 51.32 & 50.79 & 53.34 \\
\hline Viscosity (cP) & 0.53 & 1.47 & 2.14 \\
\hline Heating Value (Btu/lb) & 21,481 & 19,750 & 19,500 \\
\hline
\end{tabular}

\subsection{PRELIMINARY CAPITAL COST ESTIMATION}

Based on the feasibility analysis conducted, a gross cost estimate for the project with order of magnitude accuracy is presented in Table 3-8. It should be noted that the full scope of the project has not been defined and the actual cost will be clearer after a more detailed definition of the project is developed. The costs projected are only for taking the waste streams from the batch reactors and converting them to a suitable continuous stream for the CHP device. The costs in Table 3-8 do not include the costs associated with the CHP equipment, which are summarized in Section 5 of this report. In addition, the costs do not include costs for aqueous waste or hazardous waste storage and disposal. The capital cost of implementing the described approach to converting waste streams into fuel streams will consist of expenditures estimated in Table 3-8.

It is assumed that some storage tanks exist and can be re-purposed as required. It is also anticipated that some new storage tanks will have to be purchased. The size and the design of the tanks will have to be established in next phase of analysis. A distillation column with standard packing was assumed. The reboiler and the condenser associated with the distillation column are included in the Heat Exchangers cost. Reflux drums associated with the distillation column are included in the Tanks and Vessels cost. The availability of required process utilities such as steam and cooling water is assumed to exist on site at the required capacity and quality (pressure, temperature, etc.). The process piping cost includes piping, valves and pumps. Process automation costs include the instrumentation and controls associated with the distillation column and some updates to existing systems. The order of magnitude total capital cost is

\begin{tabular}{lcc|}
\hline U.S. DOE/NETL & $3-10$ & Burns \& \\
AMPAC Fine Chemicals & & McDonnell \\
Sacramento Municipal Utility District & & siwce 1898 \\
\hline
\end{tabular}


anticipated to be approximately $\$ 1.85$ million. Other costs such as demolition, site development, start-up, engineering and construction are not included in this value. The value is based on the preliminary feasibility analysis conducted and may change drastically based on the final scope of the project.

Table 3-8 Waste to Fuel System Capital Cost Estimates

\begin{tabular}{|l|r|}
\hline Description & Amount \\
\hline Tanks and Vessels & 150,000 \\
\hline Distillation Column & 300,000 \\
\hline Heat Exchangers & 250,000 \\
\hline Process Utilities & 100,000 \\
\hline Process Piping & 300,000 \\
\hline Process Automation (instrumentation/controls) & 500,000 \\
\hline Civil, Structural, Architecture & 150,000 \\
\hline Electrical & 100,000 \\
\hline Total & $\mathbf{1 , 8 5 0 , 0 0 0}$ \\
\hline
\end{tabular}

In addition to the equipment presented in Table 3-8, a vaporizer is also required. Depending on the specifications, the cost of the vaporizer is estimated to be $\$ 800,000$ to $\$ 1,100,000$. This cost includes the skid and accessories. The variance is driven primarily by the level of complexity in the number of valves, heat tracing, controls and instrumentation required.

A summation of the capital costs associated with the waste-to-fuel process is shown in Table 3-9. Capital costs include the waste to fuel system detailed in Table 3-8, as well as vaporizer equipment which would vary depending on the complexity of the CHP configuration. Along with the capital costs described in this section, an allowance for engineering and project management costs, general contractor costs, escalation costs, and contingency are identified. Total costs are estimated to be \$3.6 million to \$4.0 million depending on the vaporizer. 
Table 3-9 Capital Cost Estimates Including Vaporizer Equipment

\begin{tabular}{|c|c|c|c|c|}
\hline \multirow{2}{*}{$\begin{array}{l}\text { Description } \\
\text { Waste to Fuel System }\end{array}$} & \multicolumn{2}{|c|}{$\begin{array}{l}\text { Less Complex } \\
\text { Configuration }\end{array}$} & \multicolumn{2}{|c|}{$\begin{array}{l}\text { More Complex } \\
\text { Configuration }\end{array}$} \\
\hline & $\$$ & $1,850,000$ & $\$$ & $1,850,000$ \\
\hline Vaporizer & & $\underline{800,000}$ & & $\underline{1,100,000}$ \\
\hline Subtotal Direct Costs & $\$$ & $2,650,000$ & $\$$ & $2,950,000$ \\
\hline Engineering and Project Management (8\%) & $\$$ & 212,000 & $\$$ & 236,000 \\
\hline General Contractor (8\%) & & 212,000 & & 236,000 \\
\hline Escalation (2012 - 2014) (2\%/yr) & & $\underline{53,000}$ & & $\underline{59,000}$ \\
\hline Subtotal Indirect Costs & $\$$ & 477,000 & $\$$ & 531,000 \\
\hline Subtotal Direct \& Indirect Costs & $\$$ & $3,127,000$ & $\$$ & $3,481,000$ \\
\hline Contingency (15\%) & & 469,000 & & $\underline{522,000}$ \\
\hline Total & $\$$ & $3,596,000$ & $\$$ & $4,003,000$ \\
\hline
\end{tabular}

\subsection{MANUFACTURER FUEL COMPATIBILITY OPINIONS}

Information on the chemical composition and quantities of the byproduct fuel components was provided to Cleaver-Brooks, Solar Turbines, and LPP Combustion, along with a request to provide an opinion on the following issues related to burning the byproduct fuel in their combustion device:

- The compatibility of the byproduct fuel with their combustion device

- An opinion on the likely emissions characteristic

- A brief scope of work and estimated cost to perform testing to establish compatibility and define the emissions characteristics

- The quantity of fuel required for such a test

\subsubsection{Cleaver-Brooks}

Cleaver Brooks indicated the liquid waste stream would burn well and was compatible with their combustion device. Air atomizing or mechanical atomizing is recommended depending on the estimated total flow of fuel and turndown requirements. 
The likely emissions characteristics were estimated to be as follows:

- $\quad$ FBN 0.02 percent

- $\quad \mathrm{NOx}<250 \mathrm{ppm}$

A brief scope of work and estimated cost to perform testing to verify fuel compatibility and establish emissions characteristics included the following steps, which include the typical scope of services that Cleaver-Brooks follows for the firing test of a liquid waste stream.

1. Customer will ship a small quantity of sample fuel (typically 1 gallon) to Cleaver-Brooks for analysis.

2. If Cleaver-Brooks determines that the byproduct fuel has a potential for being a suitable fuel, customer will ship a complete test sample to Cleaver-Brooks R\&D facility in Milwaukee. The test quantity will be determined by the analysis (typically 100 gallons-minimum).

3. Cleaver-Brooks will set up a temporary fuel delivery system to one of the appropriate boilers at the R\&D facility.

4. The sample will be fired in the Cleaver-Brooks boiler at a range of firing rates with samples taken for each one.

5. A formal test report will be prepared and delivered to the customer.

6. The price will be negotiated when the test scope and customer requirements have been defined.

\subsubsection{Solar Turbines}

Solar Turbines identified the following issues for combustion.

- Potential two phase fuel flow because of the volatility of the fuels.

- Heating value of the fuel is 30 percent lower than diesel fuel causing the turbine to be derated.

- High oxygen content of the fuel will require adjustment of the air fuel ratio.

- Sulfur and chlorine in the fuel is potentially corrosive to the engine and fuel train.

- High level of fuel bound nitrogen will result in High level of NOx.

- Turbine starting, acceleration and stopping will require standard fuel.

- Special requirements for the fuel pump and system.

- Significant testing will be required to determine compatibility.

\subsubsection{LPP Combustion}

LPP Combustion indicated the by-product waste streams as identified and qualified by Burns \& McDonnell appear to be very compatible for vaporization by the LPP Combustion process into LPP Gas $^{\mathrm{TM}}$ that can be safely utilized in the following combustion devices:

- A gas turbine dry low NOx combustor.

\begin{tabular}{l}
\hline U.S. DOE/NETL \\
AMPAC Fine Chemicals
\end{tabular}


- A gas turbine with a diffusion burner.

- Any other type of industrial or boiler burner designed for natural gas operation.

LPP Combustion agreed that the ethyl bromide and t-butylbromide should be removed from Stream ACC-288 prior to vaporization of the balance. Additionally, LPP Combustion also agreed that Stream ACC340.2 which is primarily methylene chloride is not a good candidate for vaporizing into a clean, natural gas-equivalent fuel.

LPP Combustion can test Stream ACC-289 with and without the chloromethyl-2propylcarbonate to determine the effects of chloride in the Capstone C30 gas turbine in its test facility. The Capstone fuel gas specification 410002 Rev. F (January 2009) states the Capstone units are capable of using gaseous fuels with up to $1500 \mathrm{ppm}$ chlorides.

LPP Combustion noted the baseline emissions for the Capstone C30 are typically as follows:

- Approximately 5 ppm NOx.

- CO emissions varying somewhat by fuel in the range of $25 \mathrm{ppm}$.

LPP Combustion would expect approximately the same emissions in vaporizing the waste streams into an LPP Gas ${ }^{\mathrm{TM}}$ They also noted the following:

- Potential quantitative conversion of fuel-bound nitrogen from the following components: acetonitrile, dimethylformamide, N-methyl-2-pyrrolidone, and triethylamine. These fuels will increase the baseline NOx emissions above the 5 ppm seen with fuels with no nitrogen.

- Some SOx formation may come from the methanesulfonic acid.

For testing purposes, LPP Combustion would like to obtain 20 gallons of the proposed fuel to vaporize and run through the C30. They would measure NOx and CO emissions with their in-house monitoring equipment. Testing would take about two weeks at an estimated price of $\$ 11,500$. If a complete profile of all exhaust gas constituents is required, a grab sample could be taken and sent out for analysis for extra cost. 
SECTION 4.0 CHP S YS TEM ALTERNATIVES 


\subsection{CHP SYSTEM ALTERNATIVES}

\subsection{OVERVIEW}

The selected CHP technologies considered in this study included the following alternatives.

- Option 1: A single CHP plant equipped with a 4.6 MW gross Solar Turbines Mercury 50 Combustion Turbine

- Option 2: A single CHP plant equipped with nine 200 kW gross Capstone C200 Microturbines

- Option 3: A single CHP plant equipped with two 1,137 kW gross GE Jenbacher JMS 416

Reciprocating Engines

Each option has been paired with waste to fuel capability as described in Section 3 of this report. Each option includes the appropriate vaporizer equipment, as is detailed further in this section of the report. In each of the configurations considered, the waste heat recovered from the prime mover's exhaust would be used to meet a portion of the site's thermal load. The waste to fuel capability provides opportunities to convert chemical waste to offset purchased natural gas in the operation of the CHP facility. Descriptions for each of the CHP configurations are presented in the remainder of this section.

\subsection{OPTION 1 - SINGLE CHP PLANT WITH COMBUSTION TURBINE}

Option 1 employed a Solar Turbines Mercury 50 Combustion Turbine with an estimated net generation output of 4,379 kW and a HRSG with an unfired steam output of 14,376 lb/hr. Since all of the steam generation capacity would be located at the South CHP Plant, 3000 feet of steam and condensate return piping would be required in order to interconnect the north and south steam distribution systems.

Connecting the two sites would allow the $14,376 \mathrm{lb} / \mathrm{hr}$ of steam generation capacity to meet the combined north and south site minimum thermal load of $12,500 \mathrm{lb} / \mathrm{hr}$. The steam would preheat 7,000 lb/hr of $70{ }^{\circ} \mathrm{F}$ makeup water to $200{ }^{\circ} \mathrm{F}$ at the south site before entering the HRSG. Duct firing in the HRSG will provide the balance of the steam requirement for peak load which would allow the existing boilers to remain in service only for redundancy. Natural gas requirements for the CHP facility will be reduced by 17 MMBtu/hr resulting from the waste fuel produced. The new CHP equipment would be in manufacturer supplied weatherproof enclosures and located adjacent to the existing South boiler house plant on a concrete pad. Electrical interconnection would be installed at the main substation. A general process flow diagram of Option 1 is presented in Appendix A. 


\subsection{OPTION 2 - SINGLE CHP PLANT WITH MICROTURBINES}

Option 2 would employ nine Capstone C200 Microturbines with a total net generation output of 1,764 kW, and a HRSG with a total unfired steam output of approximately 6,300 lb/hr. Since the total unfired HRSG's output would be near the minimum thermal load of the south site, it would not be necessary to interconnect the two sites so that the new CHP plant could serve the thermal loads of both sites. It is anticipated that the waste fuel equipment would be able to meet the majority of the south site's CHP fuel requirements. A general process flow diagram of Option 2 is presented in Appendix A.

\subsection{OPTION 3 - SINGLE CHP PLANT WITH RECIPROCATING ENGINES}

Option 3 includes a single CHP plant adjacent to the south site boiler house, including two GE Jenbacher JMS 416 reciprocating engines, each with a net generation output of 1,114 kW, and HRSGs with an effective unfired steam output of 2,231 lb/hr. The CHP plant would have a total net generation output of $2,229 \mathrm{~kW}$ and total unfired steam output of 4,462 lb/hr. It is anticipated that the waste fuel provided would meet the majority of the south site's CHP fuel requirements. Under this configuration, no interconnecting piping would be included between the two sites. A general process flow diagram of Option 3 is presented in Appendix A.

\subsection{CHP PLANT CONFIGURATION SUMMARY}

The CHP plants configurations' assumptions regarding prime mover technology type, electrical generation output, fuel consumption, efficiency, steam generation output and number of units is presented in Table 4-1. These assumptions were used as the basis for determining the approximate capital cost of each option and provided the basis for the economic analysis of each configuration. 
Table 4-1: CHP Plant Configurations - Performance Assumptions

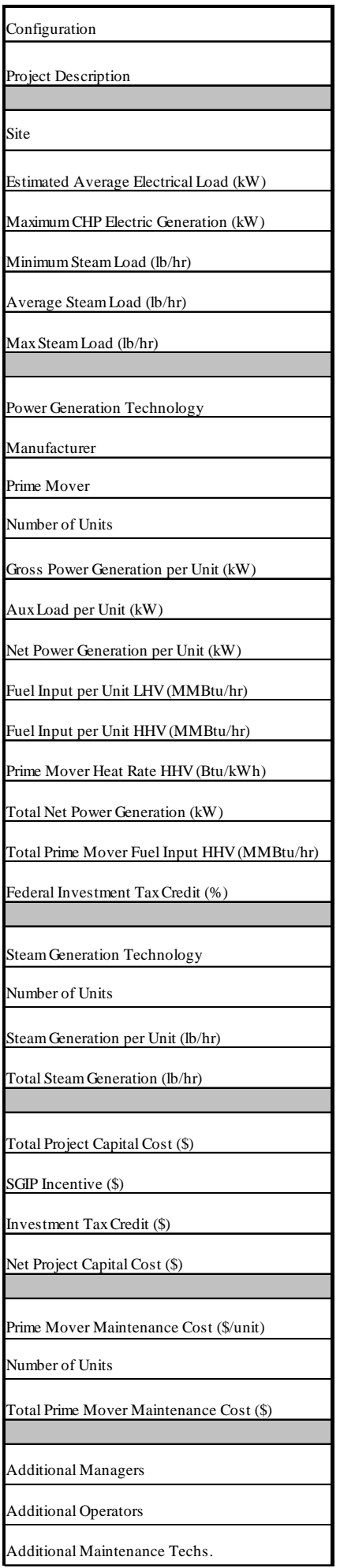

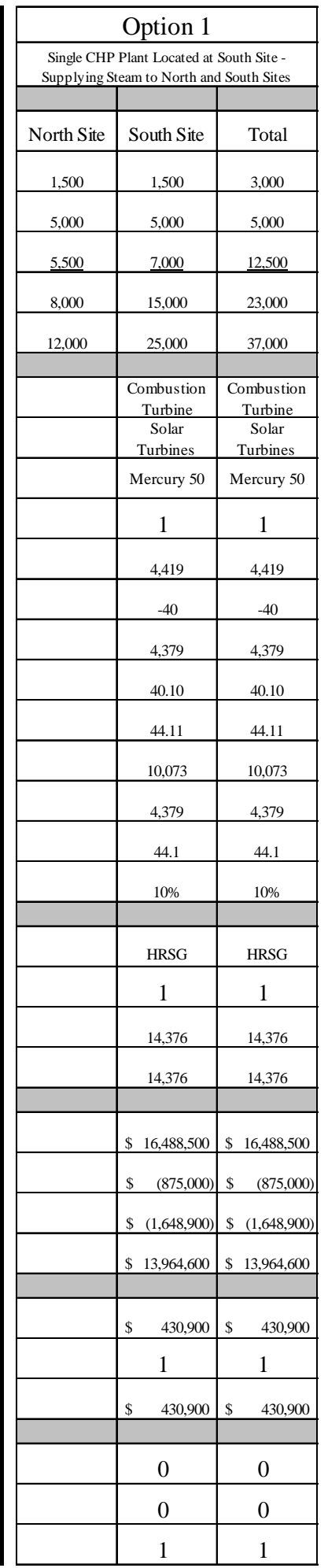

\begin{tabular}{|c|c|c|}
\hline \multicolumn{3}{|c|}{ Option 2} \\
\hline \multicolumn{3}{|c|}{$\begin{array}{l}\text { Single CHP Plant Located at South Site - No } \\
\text { Steam Interconnection }\end{array}$} \\
\hline & & \\
\hline \multirow[t]{23}{*}{ North Site } & South Site & Total \\
\hline & 1,500 & 1,500 \\
\hline & 5,000 & 5,000 \\
\hline & 7,000 & 7,000 \\
\hline & 15,000 & 15,000 \\
\hline & 25,000 & 25,000 \\
\hline & Microturbine & Microturbine \\
\hline & Capstone & Capstone \\
\hline & $\mathrm{C} 200 \times 9$ & $\mathrm{C} 200 \times 9$ \\
\hline & 1 & 1 \\
\hline & 1,800 & 1,800 \\
\hline & -36 & -36 \\
\hline & 1,764 & 1,764 \\
\hline & 17.00 & 17.00 \\
\hline & 18.70 & 18.70 \\
\hline & 10,601 & 10,601 \\
\hline & 1,764 & 1,764 \\
\hline & 18.7 & 18.7 \\
\hline & $10 \%$ & $10 \%$ \\
\hline & HRSG & HRSG \\
\hline & 1 & 1 \\
\hline & 6,300 & 6,300 \\
\hline & 6,300 & 6,300 \\
\hline & $\$ 11,972,800$ & $\$ 11,972,800$ \\
\hline & $\$ \quad(691,000)$ & $\$ \quad(691,000)$ \\
\hline & $\$(1,197,300)$ & $\$(1,197,300)$ \\
\hline & $\$ 10,084,500$ & $\$ 10,084,500$ \\
\hline & $\$ \quad 301,500$ & 301,500 \\
\hline & 1 & 1 \\
\hline & $\$ \quad 301,500$ & 301,500 \\
\hline & 0 & 0 \\
\hline & 0 & 0 \\
\hline & 1 & 1 \\
\hline
\end{tabular}

\begin{tabular}{|c|c|c|}
\hline \multicolumn{3}{|c|}{ Option 3} \\
\hline \multicolumn{3}{|c|}{$\begin{array}{l}\text { Single CHP Plant Located at South Site - No } \\
\text { Steam Interconnection }\end{array}$} \\
\hline \multirow[t]{23}{*}{ North Site } & South Site & Total \\
\hline & 1,500 & 1,500 \\
\hline & 5,000 & 5,000 \\
\hline & 7,000 & $\underline{7,000}$ \\
\hline & 15,000 & 15,000 \\
\hline & 25,000 & 25,000 \\
\hline & $\begin{array}{c}\text { Reciprocating } \\
\text { Engine }\end{array}$ & $\begin{array}{c}\text { Reciprocating } \\
\text { Engine }\end{array}$ \\
\hline & GE & GE \\
\hline & $\begin{array}{l}\text { Jenbacher } \\
\text { JMS } 416\end{array}$ & $\begin{array}{c}\text { Jenbacher } \\
\text { JMS } 416\end{array}$ \\
\hline & 2 & 2 \\
\hline & 1,137 & 1,137 \\
\hline & -23 & -23 \\
\hline & 1,114 & 1,114 \\
\hline & 9.78 & 9.78 \\
\hline & 10.75 & 10.75 \\
\hline & 9,651 & 9,651 \\
\hline & 2,229 & 2,229 \\
\hline & 21.5 & 21.5 \\
\hline & $10 \%$ & $10 \%$ \\
\hline & HRSG & HRSG \\
\hline & 2 & 2 \\
\hline & 2,231 & 2,231 \\
\hline & 4,462 & 4,462 \\
\hline & $\$ 10,032,100$ & $\$ 10,032,100$ \\
\hline & $\$ \quad(529,100)$ & $\$ \quad(529,100)$ \\
\hline & $\$(1,003,200)$ & $\$(1,003,200)$ \\
\hline & $\$ \quad 8,499,800$ & $\$ \quad 8,499,800$ \\
\hline & $\$ \quad 137,100$ & 137,100 \\
\hline & 2 & 2 \\
\hline & \$ $\quad 274,200$ & $\$ \quad 274,200$ \\
\hline & 0 & 0 \\
\hline & 0 & 0 \\
\hline & 1 & 1 \\
\hline
\end{tabular}


SECTION 5.0

CAP ITAL COSTS 


\subsection{CAPITAL COSTS}

\subsection{OVERVIEW}

Burns \& McDonnell developed screening level capital cost estimations for each CHP configuration by obtaining quotes from vendors for the major equipment and using our construction cost database for the balance of plant costs.

\subsection{OPTION 1 - SINGLE CHP PLANT WITH COMBUSTION TURBINE}

Option 1 employs a Solar Turbines Mercury 50 Combustion Turbine, a HRSG and associated equipment. Since all of the steam capacity would be located at the south plant, steam and condensate return piping to the north site is required along with a new deaerator, reverse osmosis system, and condensate tank. Table 5-1 summarizes the major cost estimate line items required for Option 1, as well as the cost for the Waste to Fuel System and Fuel Vaporizer described in Section 3 of this report.

Table 5-1: Single CHP Plant with Combustion Turbine - Capital Cost Estimate

\begin{tabular}{|c|c|c|c|c|c|c|c|c|c|c|c|c|}
\hline Item Description & Qty & Units & & Jnit Matl & & Jnit Lbr & & Total Matl & & Total Lbr & & Total \\
\hline \multicolumn{13}{|l|}{ Equipment Summary } \\
\hline Mercury 50 & 1 & $\mathrm{pc}$ & $\$$ & $3,623,400$ & $\$$ & 362,340 & $\$$ & $3,623,400$ & $\$$ & 362,300 & $\$$ & $3,985,700$ \\
\hline Mercury 50 startup & 1 & pc & & - & & 160,000 & & - & & 160,000 & & 160,000 \\
\hline Gas compressor & 1 & pc & & 350,000 & & 160,000 & & 350,000 & & 160,000 & & 510,000 \\
\hline Turbine freight & 1 & $\mathrm{pc}$ & & - & & 140,000 & & - & & 140,000 & & 140,000 \\
\hline HRSG ERI w/diverter valve & 1 & pc & & 900,000 & & 90,000 & & 900,000 & & 90,000 & & 990,000 \\
\hline Stack & 1 & $\mathrm{pc}$ & & 90,000 & & 9,000 & & 90,000 & & 9,000 & & 99,000 \\
\hline Condensate tank with pumps & 1 & $\mathrm{pc}$ & & 35,000 & & 3,500 & & 35,000 & & 3,500 & & 38,500 \\
\hline Deaerator with boiler feed pumps & 1 & $\mathrm{pc}$ & & 90,000 & & 9,000 & & 90,000 & & 9,000 & & 99,000 \\
\hline RO system & 1 & pc & & 160,000 & & 30,000 & & 160,000 & & 30,000 & & 190,000 \\
\hline Waste to Fuel System & 1 & pc & & $1,850,000$ & & - & & $1,850,000$ & & - & & $1,850,000$ \\
\hline LPP Fuel Vaporizer & 1 & $\mathrm{pc}$ & & 800,000 & & 80,000 & & 800,000 & & 80,000 & & 880,000 \\
\hline Total Equipment & & & & & & & $\$$ & $7,898,400$ & $\$$ & $1,043,800$ & $\$$ & $8,942,200$ \\
\hline \multicolumn{13}{|l|}{ Mechanical Summary } \\
\hline Steam piping 8" & 1500 & If & $\$$ & 250 & $\$$ & - & $\$$ & 375,000 & $\$$ & - & $\$$ & 375,000 \\
\hline Condensate piping 4" & 1500 & If & & 200 & & - & & 300,000 & & - & & 300,000 \\
\hline Insulation & 3000 & If & & 4 & & - & & 12,000 & & - & & 12,000 \\
\hline Boiler feed water 2" & 100 & If & & 100 & & - & & 10,000 & & - & & 10,000 \\
\hline City water & 100 & If & & 40 & & - & & 4,000 & & - & & 4,000 \\
\hline Natural gas piping 4" & 300 & If & & 40 & & - & & 12,000 & & - & & 12,000 \\
\hline Boiler blowdown system & 1 & It & & 20,000 & & - & & 20,000 & & - & & 20,000 \\
\hline Plumbing system & 1 & It & & 40,000 & & - & & 40,000 & & - & & 40,000 \\
\hline Total Mechanical & & & & & & & $\$$ & 773,000 & $\$$ & - & $\$$ & 773,000 \\
\hline \multicolumn{13}{|l|}{ Civil Summary } \\
\hline Site Grading & 1 & ea & $\$$ & 10,000 & $\$$ & - & $\$$ & 10,000 & $\$$ & - & $\$$ & 10,000 \\
\hline Concrete Pavement & 1 & ea & & 155,000 & & - & & 155,000 & & - & & 155,000 \\
\hline Total Civil & & & & & & & $\$$ & 165,000 & $\$$ & - & $\$$ & 165,000 \\
\hline \multicolumn{13}{|l|}{ Electrical Summary } \\
\hline Electrical Equipment and Controls & 1 & ea & $\$$ & $2,000,000$ & $\$$ & - & $\$$ & $2,000,000$ & $\$$ & - & $\$$ & $2,000,000$ \\
\hline Total Electrical & & & & & & & $\$$ & $2,000,000$ & $\$$ & - & $\$$ & $2,000,000$ \\
\hline Total Direct Costs & & & & & & & & $10,836,400$ & $\$$ & $1,043,800$ & & $11,880,200$ \\
\hline Engineering and Project Management & & & & & & & & & & $8.00 \%$ & $\$$ & 950,400 \\
\hline General Contractor Fee \& Profit & & & & & & & & & & $8.00 \%$ & & 950,400 \\
\hline Escalation (2012 - 2014) & & & & & & & & & & $2.00 \%$ & & 556,800 \\
\hline Total Indirect Costs & & & & & & & & & & & & $2,457,600$ \\
\hline Total Direct \& Indirect Costs & & & & & & & & & & & & $14,337,800$ \\
\hline Contingency & & & & & & & & & & $15.00 \%$ & $\$$ & $2,150,700$ \\
\hline Total Project Costs & & & & & & & & & & & & $16,488,500$ \\
\hline
\end{tabular}




\subsection{OPTION 2 - SINGLE CHP PLANT WITH MICROTURBINES}

Option 2 employs nine Capstone C200 Microturbines, two HRSGs, and an associated balance of plant equipment. Since the new CHP plant would only tie in to the existing south site steam distribution system, minimal additional mechanical and electrical equipment would be required. In addition, since the total unfired steam output of the HRSGs is less than the minimum south site thermal load, no interconnection piping costs between the north and south sites are included in the capital cost estimate. Table 5-2 summarizes the major cost estimate line items required for Option 2.

Table 5-2: Single CHP Plant with Microturbines - Capital Cost Estimate

\begin{tabular}{|c|c|c|c|c|c|c|c|c|c|c|c|c|}
\hline Item Description & Qty & Units & & Unit Matl & & Jnit Lbr & & Total Matl & & tal Lbr & & Total \\
\hline \multicolumn{13}{|l|}{ Equipment Summary } \\
\hline Capstone Mictroturbines Modules (1,800 kW) & 1 & pc & $\$$ & $3,240,000$ & $\$$ & 324,000 & $\$$ & $3,240,000$ & $\$$ & 324,000 & $\$$ & $3,564,000$ \\
\hline Startup & 1 & pc & & - & & 160,000 & & - & & 160,000 & & 160,000 \\
\hline Waste to Fuel System & 1 & $\mathrm{pc}$ & & $1,850,000$ & & - & & $1,850,000$ & & - & & $1,850,000$ \\
\hline LPP Fuel Vaporizer & 1 & $\mathrm{pc}$ & & $1,100,000$ & & 110,000 & & $1,100,000$ & & 110,000 & & $1,210,000$ \\
\hline Total Equipment & & & & & & & $\$$ & $6,190,000$ & $\$$ & 594,000 & $\$$ & $6,784,000$ \\
\hline \multicolumn{13}{|l|}{ Mechanical Summary } \\
\hline Steam piping 8" & 200 & If & $\$$ & 250 & $\$$ & - & $\$$ & 50,000 & $\$$ & - & $\$$ & 50,000 \\
\hline Condensate piping 4" & 200 & If & & 200 & & - & & 40,000 & & - & & 40,000 \\
\hline Insulation & 400 & If & & 4 & & - & & 1,600 & & - & & 1,600 \\
\hline Boiler feed water 2" & 100 & If & & 100 & & - & & 10,000 & & - & & 10,000 \\
\hline City water & 100 & If & & 40 & & - & & 4,000 & & - & & 4,000 \\
\hline Natural gas piping 4" & 300 & If & & 40 & & - & & 12,000 & & - & & 12,000 \\
\hline Boiler blowdown system & 1 & It & & 20,000 & & - & & 20,000 & & - & & 20,000 \\
\hline Plumbing system & 1 & It & & 40,000 & & - & & 40,000 & & - & & 40,000 \\
\hline Total Mechanical & & & & & & & $\$$ & 177,600 & $\$$ & - & $\$$ & 177,600 \\
\hline \multicolumn{13}{|l|}{ Civil Summary } \\
\hline Site Grading & 1 & ea & $\$$ & 10,000 & $\$$ & - & $\$$ & 10,000 & $\$$ & - & $\$$ & 10,000 \\
\hline Concrete Pavement & 1 & ea & & 155,000 & & - & & 155,000 & & - & & 155,000 \\
\hline Total Civil & & & & & & & $\$$ & 165,000 & $\$$ & - & $\$$ & 165,000 \\
\hline \multicolumn{13}{|l|}{ Electrical Summary } \\
\hline Electrical Equipment and Controls & 1 & ea & $\$$ & $1,500,000$ & $\$$ & - & $\$$ & $1,500,000$ & $\$$ & - & $\$$ & $1,500,000$ \\
\hline Total Electrical & & & & & & & $\$$ & $1,500,000$ & $\$$ & - & $\$$ & $1,500,000$ \\
\hline Total Direct Costs & & & & & & & $\$$ & $8,032,600$ & $\$$ & 594,000 & $\$$ & $8,626,600$ \\
\hline Engineering and Project Management & & & & & & & & & & $8.00 \%$ & $\$$ & 690,100 \\
\hline General Contractor Fee \& Profit & & & & & & & & & & $8.00 \%$ & $\$$ & 690,100 \\
\hline Escalation (2012 - 2014) & & & & & & & & & & $2.00 \%$ & $\$$ & 404,300 \\
\hline Total Indirect Costs & & & & & & & & & & & $\$$ & $1,784,500$ \\
\hline Total Direct \& Indirect Costs & & & & & & & & & & & & $10,411,100$ \\
\hline Contingency & & & & & & & & & & $15.00 \%$ & $\$$ & $1,561,700$ \\
\hline Total Project Costs & & & & & & & & & & & & $11,972,800$ \\
\hline
\end{tabular}

\subsection{OPTION 3 - SINGLE CHP PLANT WITH RECIPROCATING ENGINES}

Option 3 includes a single CHP plant adjacent to the south site boiler house, including two GE Jenbacher JMS 416 reciprocating engines and two HRSGs. This option did not include interconnection between the north and south steam distribution systems since the un-fired steam capacity of the HRSGs is less than the minimum site thermal load of the south site. Table 5-3 summarizes the major cost items required for Option 3. 
Table 5-3: CHP Plant with Reciprocating Engines - Capital Cost Estimate

\begin{tabular}{|c|c|c|c|c|c|c|c|c|c|c|c|c|}
\hline \multirow{2}{*}{$\begin{array}{l}\text { Item Description } \\
\text { Equipment Summary }\end{array}$} & \multirow[t]{2}{*}{ Qty } & \multirow[t]{2}{*}{ Units } & \multicolumn{2}{|r|}{ Unit Matl } & \multicolumn{2}{|c|}{ Unit Lbr } & \multicolumn{2}{|r|}{ Total Matl } & \multicolumn{2}{|c|}{ Total Lbr } & \multicolumn{2}{|r|}{ Total } \\
\hline & & & & & & & & & & & & \\
\hline \multicolumn{13}{|c|}{$\begin{array}{l}\text { Engine generator with all engine accessories, } \\
\text { including radiators, HRSG, mufflers and SCR }\end{array}$} \\
\hline South Engine, with heat exchanger & 2 & pc & $\$$ & $1,196,900$ & $\$$ & 179,500 & $\$$ & $2,393,800$ & $\$$ & 359,000 & $\$$ & $2,752,800$ \\
\hline Waste to Fuel System & 1 & pc & & $1,850,000$ & & - & & $1,850,000$ & & - & & $1,850,000$ \\
\hline LPP Fuel Vaporizer & 1 & pc & & 800,000 & & 80,000 & & 800,000 & & 80,000 & & 880,000 \\
\hline Total Equipment & & & & & & & $\$$ & $5,113,800$ & $\$$ & 446,000 & $\$$ & $5,559,800$ \\
\hline \multicolumn{13}{|l|}{ Mechanical Summary } \\
\hline Boiler feed water 2" & 100 & If & $\$$ & 100 & $\$$ & - & $\$$ & 10,000 & $\$$ & - & $\$$ & 10,000 \\
\hline City water & 100 & If & & 40 & & - & & 4,000 & & - & & 4,000 \\
\hline Natural gas piping 4" & 300 & If & & 40 & & - & & 12,000 & & - & & 12,000 \\
\hline Boiler blowdown system & 1 & It & & 20,000 & & - & & 20,000 & & - & & 20,000 \\
\hline Plumbing system & 1 & It & & 40,000 & & - & & 40,000 & & - & & 40,000 \\
\hline Total Mechanical & & & & & & & $\$$ & 86,000 & $\$$ & - & $\$$ & 86,000 \\
\hline \multicolumn{13}{|l|}{ Civil Summary } \\
\hline Site Grading & 1 & ea & $\$$ & 5,000 & $\$$ & - & $\$$ & 5,000 & $\$$ & - & $\$$ & 5,000 \\
\hline Concrete Pavement & 1 & ea & & 77,500 & & - & & 77,500 & & - & & 77,500 \\
\hline Total Civil & & & & & & & $\$$ & 82,500 & $\$$ & - & $\$$ & 82,500 \\
\hline \multicolumn{13}{|l|}{ Electrical Summary } \\
\hline Electrical Equipment and Controls & 1 & ea & $\$$ & $1,500,000$ & $\$$ & - & $\$$ & $1,500,000$ & $\$$ & - & $\$$ & $1,500,000$ \\
\hline Total Electrical & & & & & & & $\$$ & $1,500,000$ & $\$$ & - & $\$$ & $1,500,000$ \\
\hline Total Direct Costs & & & & & & & $\$$ & $6,782,300$ & $\$$ & 446,000 & $\$$ & $7,228,300$ \\
\hline Engineering and Project Management & & & & & & & & & & $8.00 \%$ & $\$$ & 578,300 \\
\hline General Contractor Fee \& Profit & & & & & & & & & & $8.00 \%$ & & 578,300 \\
\hline Escalation (2012 - 2014) & & & & & & & & & & $2.00 \%$ & & 338,700 \\
\hline Total Indirect Costs & & & & & & & & & & & $\$$ & $1,495,300$ \\
\hline Total Direct \& Indirect Costs & & & & & & & & & & & $\$$ & $8,723,600$ \\
\hline Contingency & & & & & & & & & & $15.00 \%$ & $\$$ & $1,308,500$ \\
\hline Total Project Costs & & & & & & & & & & & $\$$ & $10,032,100$ \\
\hline
\end{tabular}


SECTION 6.0 OPERATION AND MAINTENANCE COSTS 


\subsection{OPERATION AND MAINTENANCE COSTS}

\subsection{OVERVIEW}

Burns \& McDonnell developed estimated operation and maintenance costs for each of the proposed CHP configurations. Since these CHP systems would only add equipment to existing systems, the incremental operations and maintenance costs for each system is only that which is related to the new equipment items. It is assumed that one additional industrial plant mechanic would be required to support the additional equipment for each option. Long Term Service Agreements (LTSA) will be in place for the major pieces of equipment such as turbine generators and reciprocating engines.

\subsection{OPTION 1 - SINGLE CHP PLANT WITH COMBUSTION TURBINE}

Burns \& McDonnell assumed that AFC would enter into a LTSA with Solar Turbines for the regular maintenance inspections, non-scheduled site visits, repairs, remote monitoring and diagnostics, and overhauls. The estimated annual fee for the Solar Turbine Mercury 50 Combustion Turbine LTSA, provided by Solar Turbine, is $\$ 430,900$ per year. In addition to the LTSA, Burns \& McDonnell assumed that one additional maintenance technician would be required to support the new combustion turbine, HRSG, waste fuel system, and LPP vaporizer. A wage rate of $\$ 50$ per hour or $\$ 100,000$ per year was assumed.

\subsection{OPTION 2 - SINGLE CHP PLANT WITH MICROTURBINES}

Burns \& McDonnell assumed that AFC would enter into a LTSA with Capstone for the regular maintenance inspections, non-scheduled site visits, repairs, remote monitoring and diagnostics, and overhauls. The annual fee for the LTSA is estimated to be $\$ 301,500$ based on information provided by Capstone. In addition to the LTSA, Burns \& McDonnell assumed that one additional maintenance technician would be required to support the new microturbines, HRSGs, waste to fuel system, and LPP vaporizer. A wage rate of $\$ 50$ per hour or $\$ 100,000$ per year was assumed.

\subsection{OPTION 3 - SINGLE CHP PLANT WITH RECIPROCATING ENGINES}

Burns \& McDonnell assumed that AFC would enter into a LTSA with GE Jenbacher for the maintenance of the two new engines. Maintenance for reciprocating engines will typically include maintenance labor, engine parts and materials, minor and major overhauls, and remote monitoring of engine performance for predictive maintenance purposes. The estimated total operation and maintenance costs for engines such as JMS 416 is approximately \$13 per MWh (\$2007). Assuming 8,000 hours per year of run time, and 
two new engines, the total O\&M would be approximately $\$ 274,200$ per year. In addition to the LTSA, Burns \& McDonnell assumed that one additional maintenance technician would be required to support the new reciprocating engines, HRSGs, waste to fuel equipment, and LPP vaporizer. A wage rate of \$50 per hour or $\$ 100,000$ per year was assumed. 
SECTION 7.0

ECONOMIC ANALYS IS 


\subsection{ECONOMIC ANALYSIS}

\subsection{OVERVIEW}

Burns \& McDonnell prepared an economic analysis of each of the proposed CHP configurations to determine which one provided the highest net present value (NPV) benefit under an AFC ownership structure. The analysis assumed that AFC would own and operate the CHP plant and would generate revenues from steam sales and electric sales to offset the capital cost and operating cost of the project. The steam sales would be in the form of a reduction in the amount of steam generated by natural gas fired boilers or a natural gas offset. Savings would also be provided by no longer paying for the disposal of a significant portion of waste byproduct. The electric sales would be in the form of a reduction in electric purchased from Aerojet as well as electric sales to SMUD’s grid when the CHP plant generated more electricity than AFC required. Based on input from AFC, Burns \& McDonnell assumed the project would be funded with 100 percent debt financing and a federal investment tax credit. Figure 7-1 represents the proposed business model of the proposed CHP plant project under AFC ownership.

Figure 7-1: CHP Plant Project Business Model

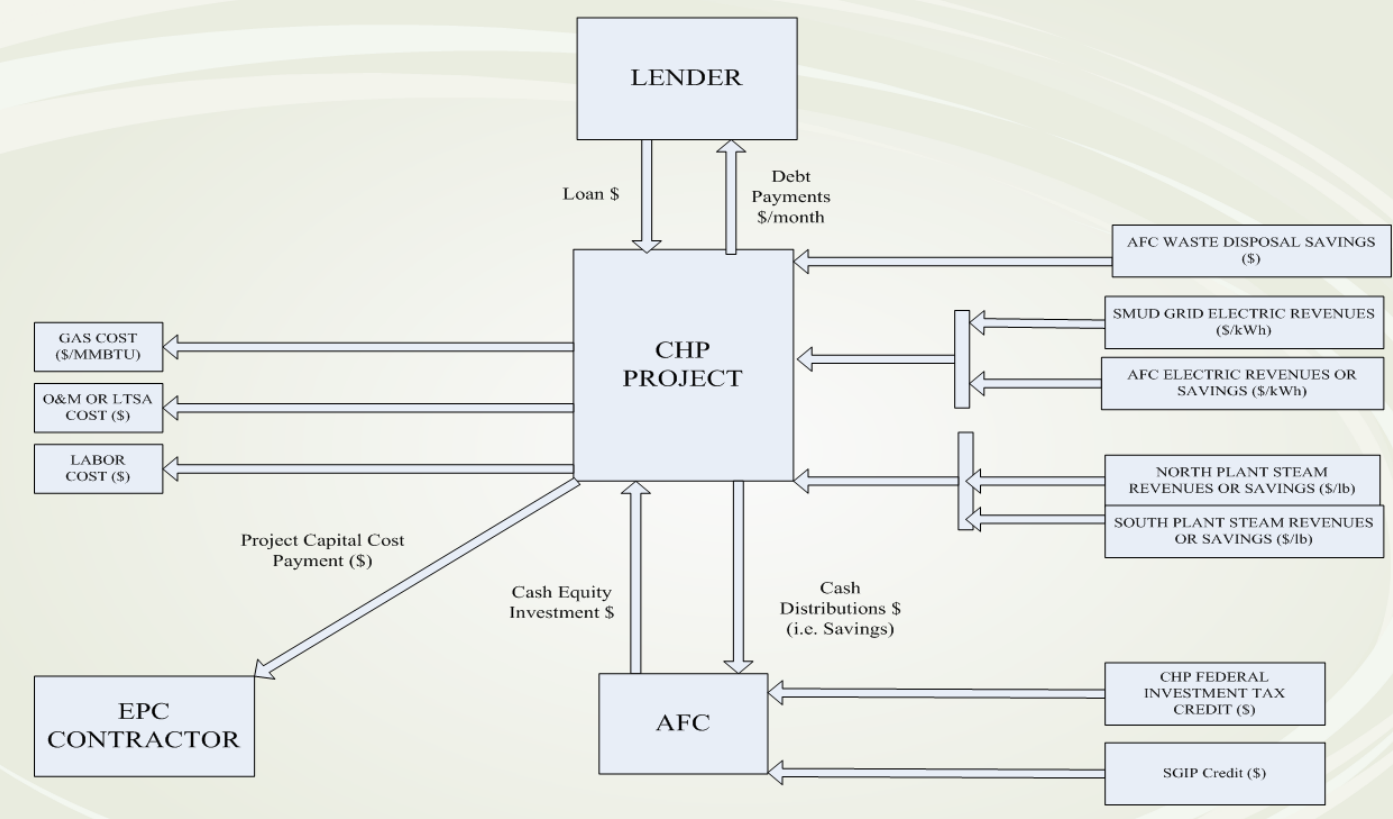




\subsection{ASSUMPTIONS}

Burns \& McDonnell worked with AFC and SMUD to develop the assumptions for the proposed CHP plant project which included economic assumptions, commodity price assumptions, and operating assumptions. The specific performance assumptions, capital cost assumptions, and O\&M cost assumptions for each CHP configuration are discussed in previous sections of this report. The general economic assumptions, commodity price assumptions, and operating assumptions are listed below:

General Economic Assumptions

- O\&M Escalation Rate

- Labor Escalation Rate

- Corporate Discount Rate

- Corporate Tax Rate

- Debt Ratio

- Debt Interest Rate

- Debt Term

- Depreciation Rate

- Maintenance Labor Rate

- CHP Investment Tax Credit

- CPUC SGIP Incentive -

Commodity Price Assumptions

- Natural Gas Commodity Rate (City Gate)

- Natural Gas CHP Transportation Rate - G-EG

- Natural Gas Boiler Transportation Rate - G-NR2

- Natural Gas Escalation Rate

- AFC Retail Electric Sales Rate

- SMUD GS TOU Escalation Rate

- SMUD Grid Electric Sales Rate

- SMUD FIT Escalation Rate

- Existing Boiler Efficiency

- Existing Boiler Steam Enthalpy

General Operating Assumptions

- CHP plants are base loaded all year

- One week forced outage per year during July

- One week planned outage per year during February

- Average annual capacity factor of $97.00 \%$.

- CHP plant sells steam to AFC (i.e. offsets gas costs) at the current cost to make steam in existing gas fired boilers

- CHP plant sells electricity to AFC (i.e. offsets electric costs) at the current GS TOU rate

- CHP plant sells surplus electricity back to SMUD at the CHP FIT rate as capable

- Avoided cost of chemical disposal is \$2,146,000 in 2012 and escalates 2.0\% annually

\footnotetext{
${ }^{1}$ Incentive payment is capped at $3 \mathrm{MW}$. For projects with capacities greater than $1 \mathrm{MW}$, the first $1 \mathrm{MW}$ receives 100 percent of the incentive rate; the next capacity increment above 1 MW up to 2 MW receives 50 percent of the incentive rate, while the last capacity increment above $2 \mathrm{MW}$ up to $3 \mathrm{MW}$ receives 25 percent of the incentive rate.

$2.00 \%$
$3.00 \%$
$15.00 \%$
$40.00 \%$
$100 \%$
$10.00 \%$
20 years
5 years MACRS
$\$ 50$ per hour
$10.00 \%$ of capital cost
$\$ 500 / \mathrm{kW}^{1}$

\$4.66 per MMBtu (2011\$) $\$ 0.30$ per MMBtu Henry Hub Futures Pricing SMUD CHP FIT Henry Hub Futures Pricing trend $85.00 \%$ average efficiency 1,047 Btu/lb 


\subsection{SUMMARY OF ECONOMIC ANALYSES}

Burns \& McDonnell developed economic models for each of the proposed CHP options to determine the total annual energy savings, annual cash flow, and return on investment. The general assumptions were combined with the technical parameters discussed in the previous sections to determine the annual operating revenues and expenses as shown in Table 7-1.

Table 7-1: CHP Plant Options - Annual Operating Revenues and Expenses

$\begin{array}{ccc}\text { Option 1 } & \text { Option 2 } & \text { Option 3 } \\ \text { Combustion Turbine } & \text { Microturbines } & \text { Reciprocating Engines } \\ 2014 & 2014 & 2014 \\ \text { Year 1 } & \text { Year 1 } & \text { Year 1 }\end{array}$

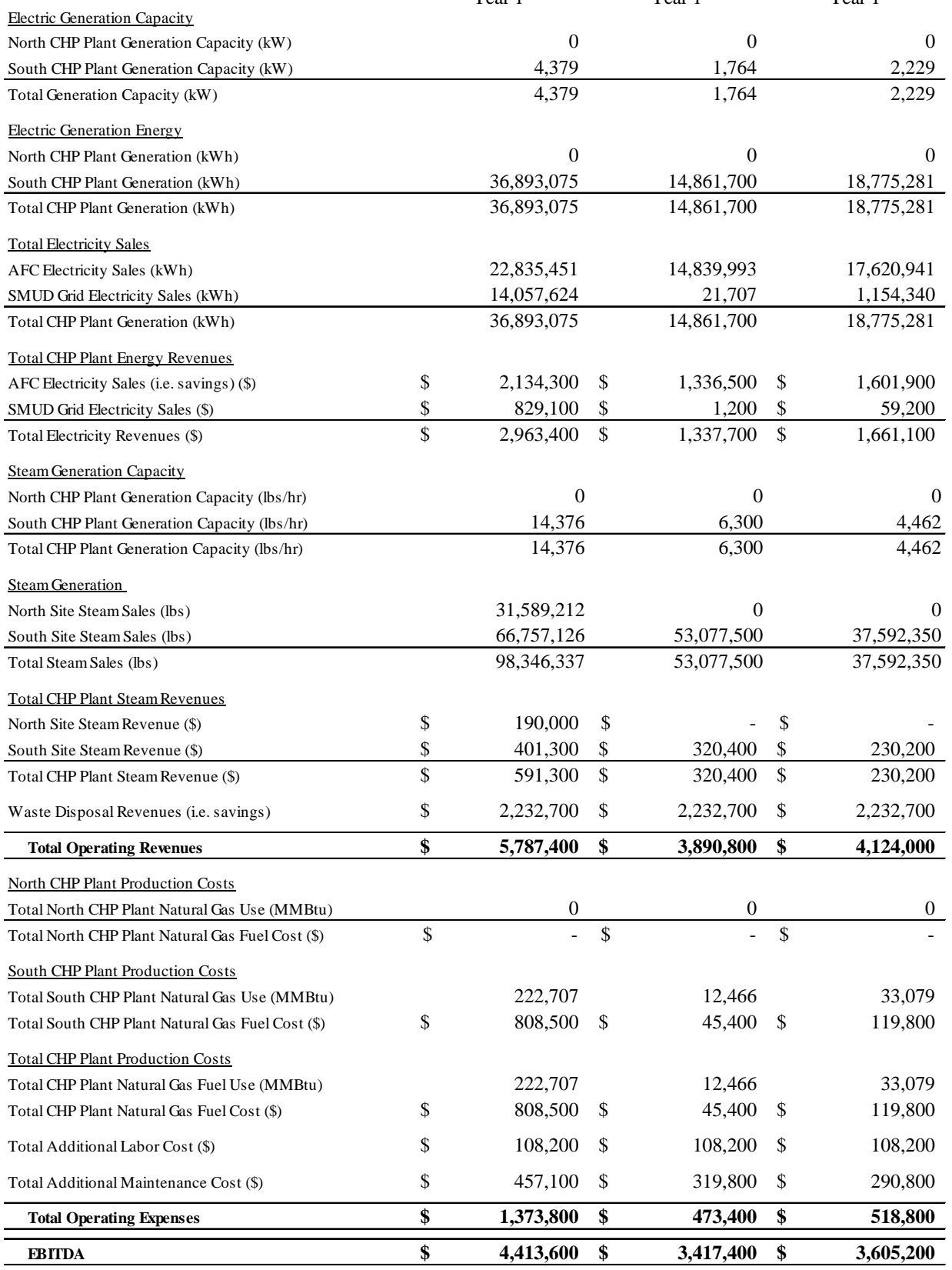


Burns \& McDonnell summarized the results of the economic analysis in the form of pro forma cash flow statements. This analysis incorporated each CHP project's accelerated depreciation, debt financing, tax incentives and capital cost. The NPV summary of this analysis is shown in Table 7-2 and the individual models’ tables are included in Appendix B.

\section{Table 7-2: CHP Plant Options - 2014 NPV Life Cycle Costs}

$\begin{array}{ccc}\text { Option } 1 & \text { Option } 2 & \text { Option } 3 \\ \text { mbustion Turbine } & \text { Microturbines } & \text { Reciprocating Engine } \\ \mathbf{2 0 1 4} & \mathbf{2 0 1 4} & \mathbf{2 0 1 4} \\ \text { NPV } & \text { NPV } & \text { NPV }\end{array}$

\section{INCOME STATEMENT}

\begin{tabular}{|c|c|c|c|c|c|c|}
\hline \multicolumn{7}{|l|}{ Operating Revenues } \\
\hline Electric Revenues & $\$$ & $22,506,400$ & $\$$ & $10,532,200$ & $\$$ & $13,019,900$ \\
\hline Steam Revenues & $\$$ & $5,285,100$ & $\$$ & $2,861,200$ & $\$$ & $2,047,700$ \\
\hline Waste Disposal Revenues & $\$$ & $15,615,400$ & $\$$ & $15,615,400$ & $\$$ & $15,615,400$ \\
\hline Total Operating Revenues & $\$$ & $43,406,900$ & $\$$ & $29,008,800$ & $\$$ & $30,683,000$ \\
\hline \multicolumn{7}{|l|}{ Operating Expenses } \\
\hline Natural Gas Expenses & $\$$ & $(7,874,800)$ & $\$$ & $(441,500)$ & $\$$ & $(1,167,500)$ \\
\hline Additional Labor Expense & $\$$ & $(756,800)$ & $\$$ & $(756,800)$ & $\$$ & $(756,800)$ \\
\hline Additional Maintenance Expense & $\$$ & $(3,388,600)$ & $\$$ & $(2,371,300)$ & $\$$ & $(2,156,600)$ \\
\hline Total Operating Expenses & $\$$ & $(12,020,100)$ & $\$$ & $(3,569,600)$ & $\$$ & $(4,080,900)$ \\
\hline EBITDA & $\$$ & $31,386,800$ & $\$$ & $25,439,200$ & $\$$ & $26,602,100$ \\
\hline \multicolumn{7}{|l|}{ Non-Operating Expenses } \\
\hline Interest Expense & $\$$ & $(7,395,200)$ & $\$$ & $(5,340,800)$ & $\$$ & $(4,501,200)$ \\
\hline Depreciation Expense & $\$$ & $(10,508,800)$ & $\$$ & $(7,611,600)$ & $\$$ & $(6,395,000)$ \\
\hline Total Non-Operating Expenses & $\$$ & $(17,904,000)$ & $\$$ & $(12,952,400)$ & $\$$ & $(10,896,300)$ \\
\hline EBT & $\$$ & $13,482,800$ & $\$$ & $12,486,900$ & $\$$ & $15,705,800$ \\
\hline \multicolumn{7}{|l|}{$\underline{\text { Taxes }}$} \\
\hline Investment Tax Credit & $\$$ & $1,433,800$ & $\$$ & $1,041,100$ & $\$$ & 872,300 \\
\hline Federal and State Tax Shield (Tax Liability) & $\$$ & $(5,393,000)$ & $\$$ & $(4,994,700)$ & $\$$ & $(6,282,300)$ \\
\hline Total Taxes & $\$$ & $(3,959,200)$ & $\$$ & $(3,953,600)$ & $\$$ & $(5,409,900)$ \\
\hline NET INCOME & $\$$ & $9,523,600$ & $\$$ & $8,533,300$ & $\$$ & $10,295,900$ \\
\hline
\end{tabular}

\section{CASH FLOW STATEMENT}

\begin{tabular}{|c|c|c|c|c|c|c|}
\hline Net Income & $\$$ & $9,523,600$ & $\$$ & $8,533,300$ & $\$$ & $10,295,900$ \\
\hline Depreciation Expense & $\$$ & $10,508,800$ & $\$$ & $7,611,600$ & $\$$ & $6,395,000$ \\
\hline Net Cash Flows Operating Activities & $\$$ & $20,032,400$ & $\$$ & $16,144,800$ & $\$$ & $16,690,900$ \\
\hline \multicolumn{7}{|l|}{ Cash Flows Capital Financing and Investing Activities } \\
\hline Proceeds From SGIP Rebate & $\$$ & 875,000 & $\$$ & 691,000 & $\$$ & 529,100 \\
\hline Proceeds From Debt & $\$$ & $13,964,600$ & $\$$ & $10,084,500$ & $\$$ & $8,499,800$ \\
\hline Capital Acquisition Payments & $\$$ & $(16,488,500)$ & $\$$ & $(11,972,800)$ & $\$$ & $(10,032,100)$ \\
\hline Principal Payments & $\$$ & $(2,872,000)$ & $\$$ & $(2,073,400)$ & $\$$ & $(1,748,100)$ \\
\hline Net Cash Flows Capital Financing and Investing Activities & $\$$ & $(4,520,900)$ & $\$$ & $(3,270,700)$ & $\$$ & $(2,751,300)$ \\
\hline Total Net Cash Flow & $\$$ & $15,511,500$ & $\$$ & $12,874,100$ & $\$$ & $13,939,700$ \\
\hline Discount Rate & & $15.00 \%$ & & $15.00 \%$ & & $15.00 \%$ \\
\hline
\end{tabular}

\begin{tabular}{l}
\hline U.S. DOE/NETL \\
AMPAC Fine Chemicals
\end{tabular}


All scenarios examined in Table 7-2 provide substantial economic benefit to AFC. Option 1 provides the greatest benefit to AFC with a \$15.51 million positive NPV total net cash flow. Under traditional capital budgeting concepts, given the mutually exclusive nature of these options, Option 1 would be recommended for further examination and development.

The results of all three alternatives are significantly influenced by the recognition of avoided cost associated with reduced chemical byproduct waste disposal. As previously identified in Table 3-9, the incremental capital cost associated with the waste to fuel system and LPP vaporizer are approximately \$3.5 million to \$4.0 million. The benefit provided by these systems is driven mainly by the reduction in cost associated with chemical byproduct waste disposal, and to a lesser degree by the reduction in the purchase of natural gas to operate the CHP facility. With an assumed benefit in chemical byproduct disposal of over \$2 million per year, the payback on these facilities is exceptionally fast, even before the benefit of reduced natural gas purchases is considered. Table 7-2 shows the NPV of the avoided cost of chemical waste disposal, shown as waste disposal project revenues, to be \$15.6 million.

At the request of AFC, all scenarios depicted in Table 7-2 assume the projects are funded through 100 percent debt. Burns \& McDonnell recommends examining the projects on an unleveraged basis as well, as this approach eliminates the economic distortion that can result when examining results on a leveraged basis. The results under this unleveraged approach are shown in Table 7-3.

Table 7-3: CHP Plant Configurations -Unleveraged Indicators

\begin{tabular}{|c|c|c|c|c|c|c|}
\hline & & & $\begin{array}{l}\text { Option } 1 \\
\text { ustion Turbine }\end{array}$ & & $\begin{array}{c}\text { Option } 2 \\
\text { Microturbines }\end{array}$ & $\begin{array}{c}\text { Option } 3 \\
\text { Reciprocating Engines }\end{array}$ \\
\hline Leveraged 2014 NPV (Table 7.2) & & $\$$ & $15,511,500$ & $\$$ & $12,874,100$ & $13,939,700$ \\
\hline Unleveraged 2014 NPV & $9,888,600$ & $\$$ & $8,855,900$ & $\$$ & $8,067,500$ & $9,888,600$ \\
\hline Discounted Payback Period & 2 Years 9 Mos & & 3 Years 5 Mos & & 3 Years 2 Mos & 2 Years 9 Mos \\
\hline Modified Internal Rate of Return (MIRR) & $19.18 \%$ & & $17.61 \%$ & & $18.14 \%$ & $19.18 \%$ \\
\hline
\end{tabular}

For reference, the leveraged NPV results initially presented in Table 7-2 are shown at the top of Table 7-

3. The unleveraged 2014 NPV results are shown on the second line of the table. Two observations may be drawn from the unleveraged NPV results. First, the unleveraged NPV results now favor Option 3 rather than Option 1 when the project is assumed to be equity funded rather than debt funded. Second, the overall results for each scenario are more tightly clustered than the leveraged results.

A discounted payback period was calculated for the options, which reflects the amount of time the cumulative discounted cash flows take to pay back the initial investment. The payback period results 
show relatively little variance between the options, showing that all three options are projected to pay back at a similar rate.

A modified internal rate of return (MIRR) was also calculated, which represents the rate at which NPV results for each project are $\$ 0.00$, assuming that project cash flows are reinvested at AFC's cost of capital. Generally speaking, MIRR and NPV results are expected to be consistent, except in conditions where cash flows are irregular or there are dramatic differences in the scale of the initial investment. As shown in Table 7-3, the unleveraged MIRR results also favor Option 3, assuming a reinvestment rate commensurate with AFC's 15 percent cost of capital. All of the unleveraged indicators support Option 3 as the most value-adding alternative, although the marginal difference among the options is relatively small.

\subsection{PROJECT SELECTION FRAMEWORK}

The results of the economic analyses summarized in Section 7.3 indicate that all options create substantial economic value. The precise ranking of the options depends on whether or not debt or equity funding is considered in the NPV analysis. However, in determining which project(s) merit further diligence and development, factors beyond economic results should be considered. These factors include:

- Proven Technology. This factor considers the strength of the feedback received from vendors, in addition to the inherent complexity of the configuration.

- Regulatory Incentives. This factor represents the general sensitivity to assumptions regarding Feed In Tariffs, economic incentives, and transmission interconnection.

- Environmental Permitting. This factor depicts risk associated with the permitting of waste fuel burning.

- Commodity Pricing. This factor captures risk associated with gas and electric pricing assumptions.

- Power Reliability. This factor acknowledges the benefit associated with each configuration's ability and scale to serve as an alternative power source.

Table 7-4 considers the findings of the economic analysis, in addition to judgments regarding factors described above, to develop a score for each option.

Table 7-4: Scoring Matrix - Leveraged NPV

\begin{tabular}{|l|c|c|c|c|c|c|}
\hline Metric & $\begin{array}{c}\text { Leveraged } \\
\text { Economic } \\
\text { Assessment }\end{array}$ & $\begin{array}{c}\text { Proven } \\
\text { Technology }\end{array}$ & $\begin{array}{c}\text { Regulatory } \\
\text { Incentives }\end{array}$ & $\begin{array}{c}\text { Environmental } \\
\text { Permitting }\end{array}$ & $\begin{array}{c}\text { Commodity } \\
\text { Pricing }\end{array}$ & $\begin{array}{c}\text { Power } \\
\text { Reliability }\end{array}$ \\
\hline Maximum Potential Score & 10 & 5 & 5 & 5 & 5 & 5 \\
Option 1: Combustion Turbine & 10 & 3 & 3 & 4 & 3 & 5 \\
Option 2: Microturbine & 8 & 5 & 5 & 4 & 5 \\
Option 3: Reciprocating Engine & 9 & 3 & 5 & 3 & 3 \\
\hline
\end{tabular}


The screening process summarized in Table 7-4 indicates Option 2 as most favorable. Option 2 benefits from greater confidence in the waste to fuel compatibility and is less influenced by changes in incentives or commodity prices. These advantages are sufficient to overcome the marginal difference in the economic analysis.

Ranking for the economic analysis used in Table 7-4 are based on the leveraged results. Using unleveraged results does not change the results for Option 2, but does decrease the score for Option 1 and increase the score for Option 2. Table 7-5 presents the unleveraged scoring matrix.

Table 7-5: Scoring Matrix - Unleveraged NPV

\begin{tabular}{|l|c|c|c|c|c|c|c|}
\hline & $\begin{array}{c}\text { Unleveraged } \\
\text { Economic } \\
\text { Assessment }\end{array}$ & $\begin{array}{c}\text { Proven } \\
\text { Technology }\end{array}$ & $\begin{array}{c}\text { Regulatory } \\
\text { Incentives }\end{array}$ & $\begin{array}{c}\text { Environmental } \\
\text { Permitting }\end{array}$ & $\begin{array}{c}\text { Commodity } \\
\text { Pricing }\end{array}$ & $\begin{array}{c}\text { Power } \\
\text { Reliability }\end{array}$ & \begin{tabular}{c} 
Score \\
\hline Maximum Potential Score
\end{tabular} \\
Option 1: Combustion Turbine & 9 & 5 & 5 & 5 & 5 & 5 & 35 \\
Option 2: Microturbine & 8 & 3 & 3 & 4 & 3 & 5 & 27 \\
Option 3: Reciprocating Engine & 10 & 5 & 5 & 4 & 5 & 3 & 30 \\
\hline
\end{tabular}

The scoring of the factors in Table 7-4 does involve a level of professional judgment and opinion. The overall difference among the options is notably narrow, suggesting all options may represent reasonable alternatives worthy of consideration.

\subsection{CONCLUSIONS}

All options evaluated in this report provide substantial economic value, significantly impacted by the ability to lower the cost of chemical byproduct waste disposal involved in the current AFC operation. Based on the scoring matrix presented in Table 7-4, Option 2 with the Capstone microturbines offers the best balance of economic value, risk, and other less tangible factors, and merits further diligence and development. 
APPENDIX A - PROCESS FLOW DIAGRAMS 


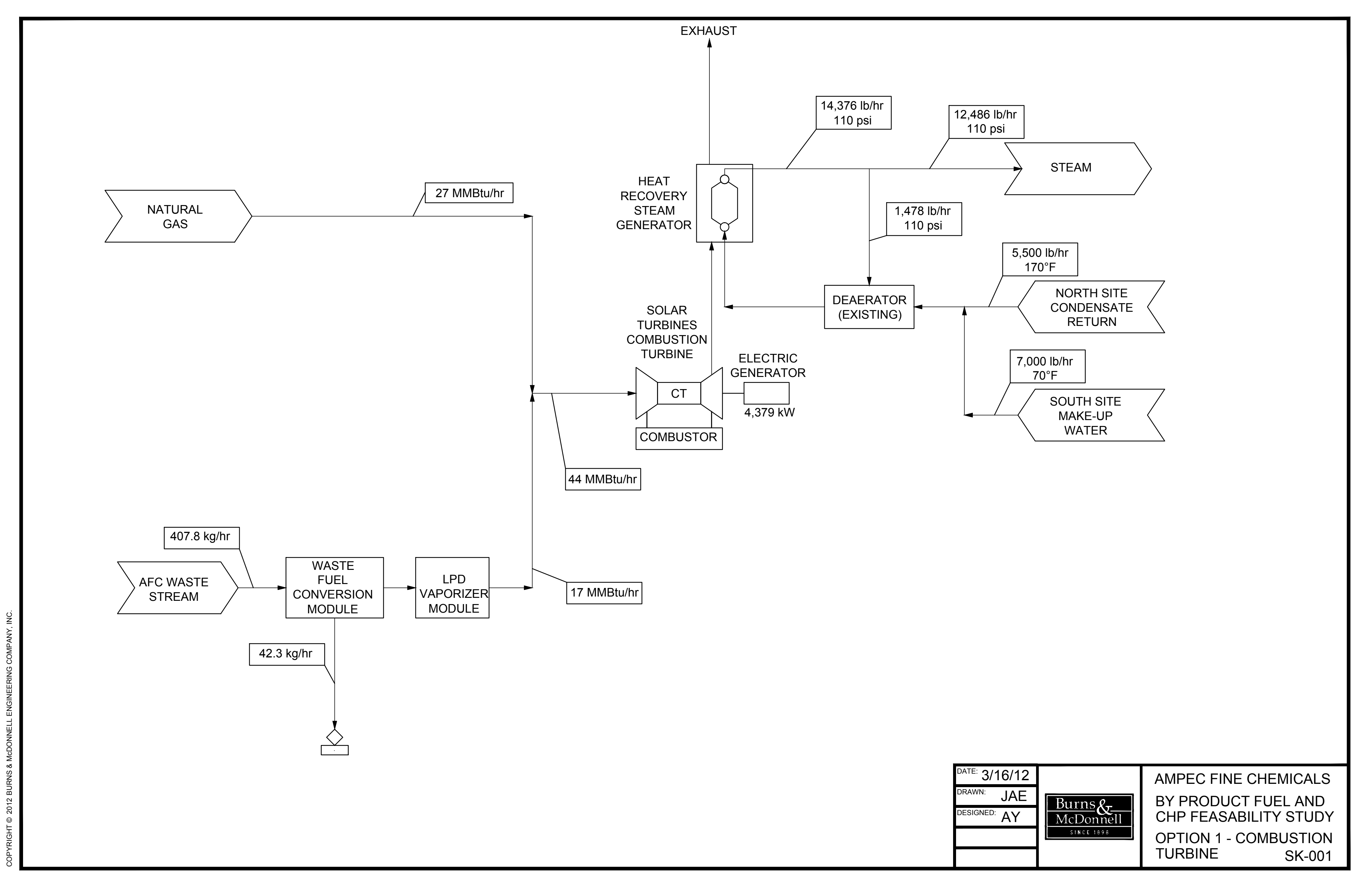



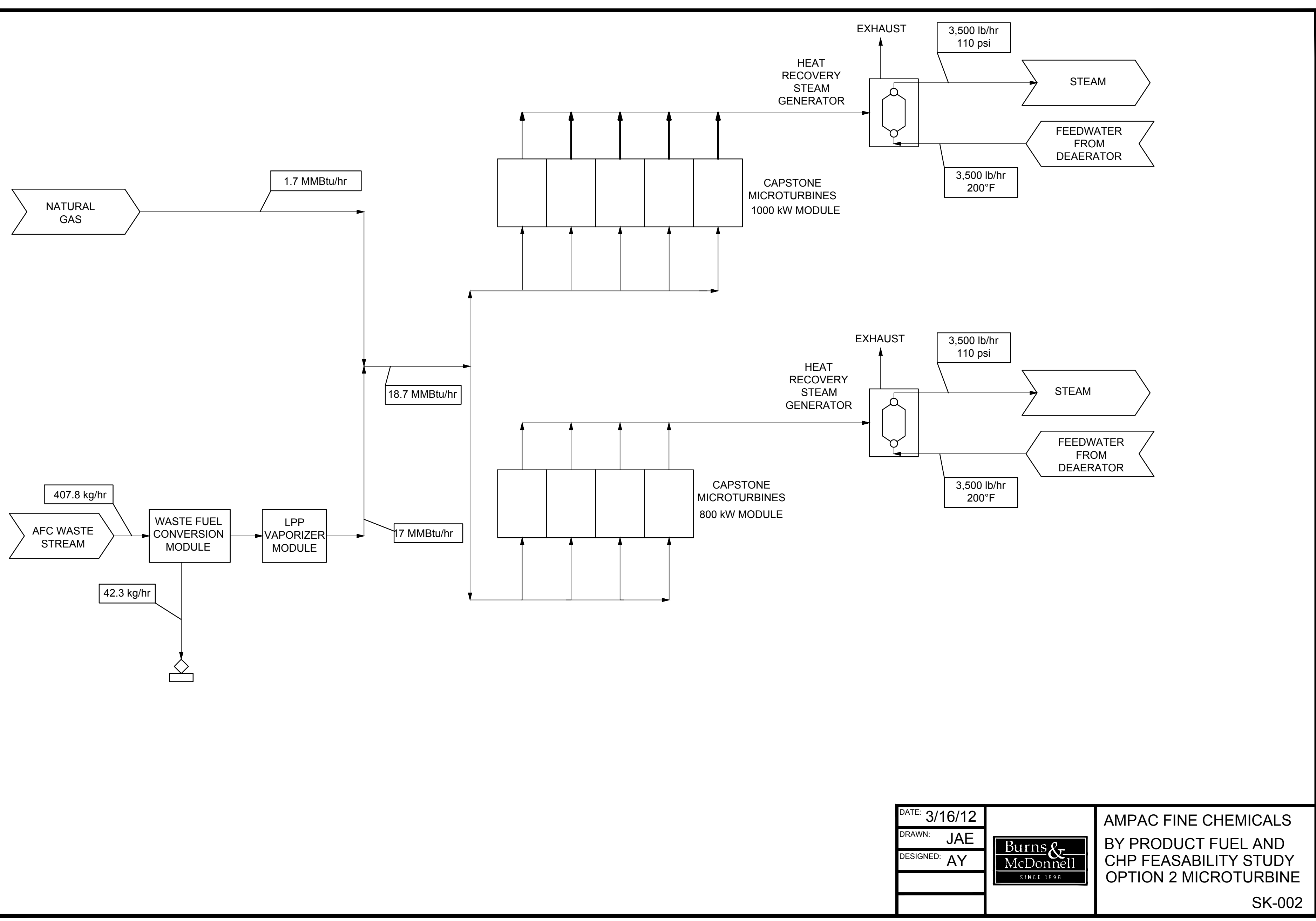


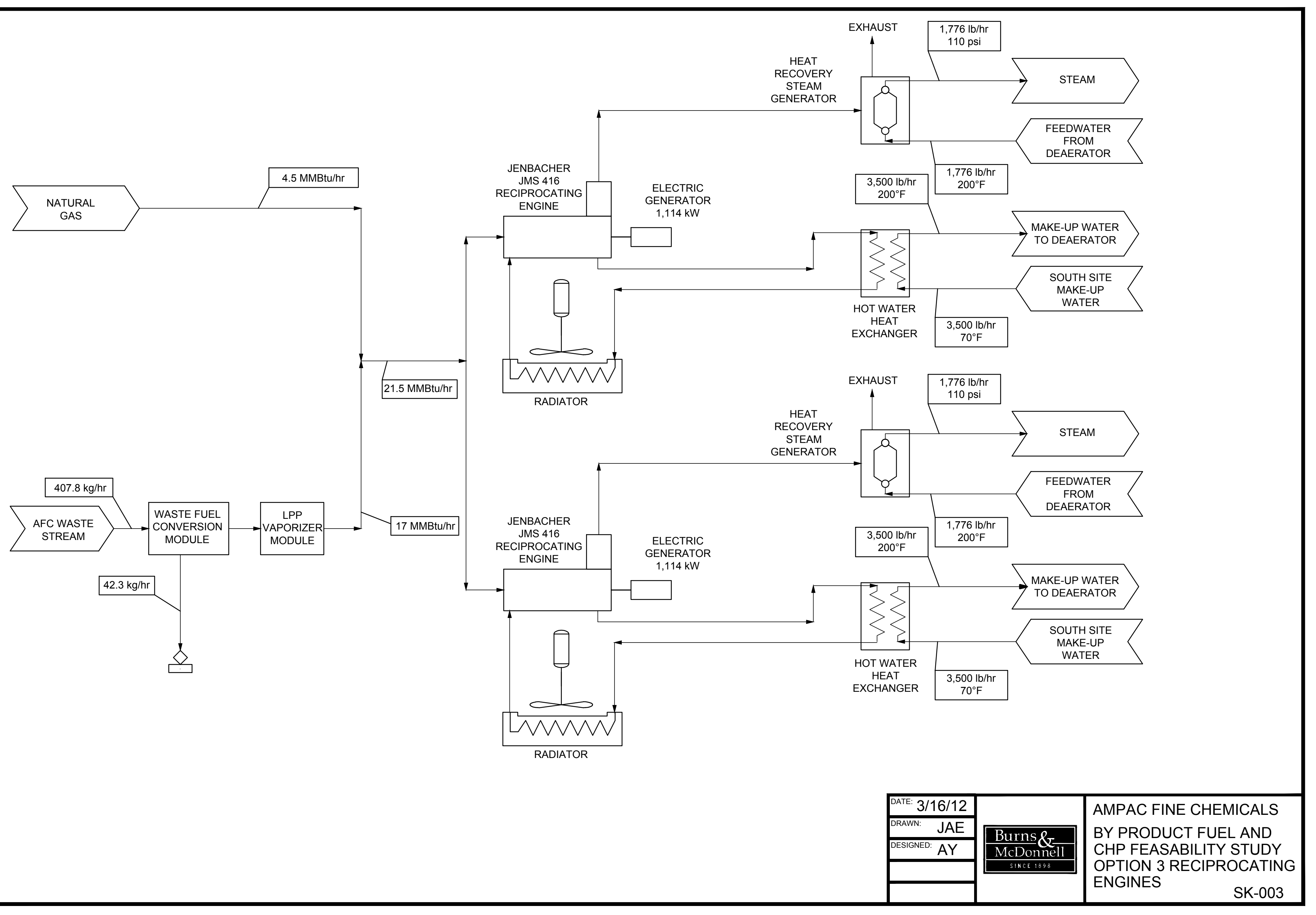


APPENDIX B - FINANCIAL MODELING RESULTS 
OPTION 1 - SINGLE CHP PLANT WITH COMBUSTION TURBINE 


\begin{tabular}{|c|c|c|c|}
\hline & \multirow{2}{*}{\multicolumn{3}{|c|}{$\begin{array}{c}\text { SELECT CONFIGURATION } \\
\text { Ontion } 1\end{array}$}} \\
\hline $\begin{array}{c}\text { Configuration } \\
\end{array}$ & & & \\
\hline Project Description & \multicolumn{3}{|c|}{$\begin{array}{c}\text { Option 1 } \\
\begin{array}{c}\text { Single CHP Plant Located at South Site - Supplying } \\
\text { Steam to North and South Sites }\end{array}\end{array}$} \\
\hline Site & North Site & South Site & Total \\
\hline Estimated Average Electrical Load $(\mathrm{kW})$ & 1,500 & 1,500 & 3,000 \\
\hline Maximum CHP Electric Generation $(k W)$ & 5,000 & 5,000 & 5,000 \\
\hline Minimum Steam Load (bb/hr) & 5,500 & 7,000 & 12,500 \\
\hline Average Steam Load (bbhr) & 8,000 & 15,000 & 23,000 \\
\hline Max Steam Load (lbhr) & 12,000 & 25,000 & 37,000 \\
\hline Power Generation Technology & 0 & $\begin{array}{c}\text { Combustion } \\
\text { Turbine }\end{array}$ & $\begin{array}{c}\text { Combustion } \\
\text { Turbine }\end{array}$ \\
\hline Manufacturer & $\mathbf{0}$ & Solar Turbines & \begin{tabular}{|l} 
Solar Turbines \\
\end{tabular} \\
\hline Prime Mover & 0 & Mercury 50 & Mercury 50 \\
\hline Number of Units & $\mathbf{0}$ & 1 & 1 \\
\hline Gross Power Generation per Unit $(\mathrm{kW})$ & 0 & 4,419 & 4,419 \\
\hline Aux Load per Unit $(k W)$ & 0 & -40 & -40 \\
\hline Net Power Generation per Unit $(\mathrm{kW})$ & 0 & 4,379 & 4,379 \\
\hline Total Power Generation $(\mathrm{kW})$ & 0 & 4,379 & 4,379 \\
\hline Fuel Input per Unit LHV (MMBtu/hr) & 0.00 & 40.10 & 40.10 \\
\hline Fuel Input per Unit HHV (MMBBuhr) & 0.00 & 44.11 & 44.11 \\
\hline Prime Mover Heat Rate LHV (Bu/kWh) & 0 & 9,157 & 9,157 \\
\hline Prime Mover Heat Rate HHV (BuukWh) & 0 & 10,073 & 10,073 \\
\hline Total Prime Mover Fuel Input LHV (MMBtuhr) & 0.0 & 40.1 & 40.1 \\
\hline Total Prime Mover Fuel Input HHV (MMBtu/hr) & 0.0 & 44.1 & 44.1 \\
\hline Federal Investment Tax Credit (\%) & $0 \%$ & $10 \%$ & $10 \%$ \\
\hline Steam Generation Technology & 0 & HRSG & HRSG \\
\hline Number of Units & 0 & 1 & 1 \\
\hline Steam Generation per Unit (lb/hr) & 0 & 14,376 & 14,376 \\
\hline Total Steam Generation (b/hr) & 0 & 14,376 & 14,376 \\
\hline Total Project Capital Cost (\$) & $\$$ & S $\quad 16,488,500$ & \$ $\quad 16,488,500$ \\
\hline SGIP Incentive (\$) & $\$$ & $\begin{array}{ll}\text { s } & (875,000) \\
\end{array}$ & S $\quad(875,000)$ \\
\hline Investment Tax Credit (\$) & $\$$ & $\$ \quad(1,648,900)$ & S $\quad(1,648,900)$ \\
\hline Net Project Capital Cost (\$) & $\$$ & S $\quad 13,964,600$ & S $\quad 13,964,600$ \\
\hline Prime Mover Maintenance Cost (S/unit) & s & 430,900 & 430,900 \\
\hline Number of Units & 0 & 1 & 1 \\
\hline Total Prime Mover Maintenance Cost (\$) & $\$$ & 430,900 & 430,900 \\
\hline Additional Managers & 0 & 0 & 0 \\
\hline Additional Operators & $\mathbf{0}$ & $\mathbf{0}$ & $\mathbf{0}$ \\
\hline Additional Maintenance & $\mathbf{0}$ & 1 & 1 \\
\hline Typical Chemical Waste Volume $(\mathrm{kg} / \mathrm{yr})$ & 0 & $3,572,000$ & $3,572,000$ \\
\hline $\begin{array}{l}\text { Ancipipated Chemical } \\
\text { Fule Facility (kg/yr) }\end{array}$ & 0 & 370,628 & 370,628 \\
\hline Fuel Input provided by WTF Vaporizer ( & 0.00 & 17.00 & 17.00 \\
\hline
\end{tabular}
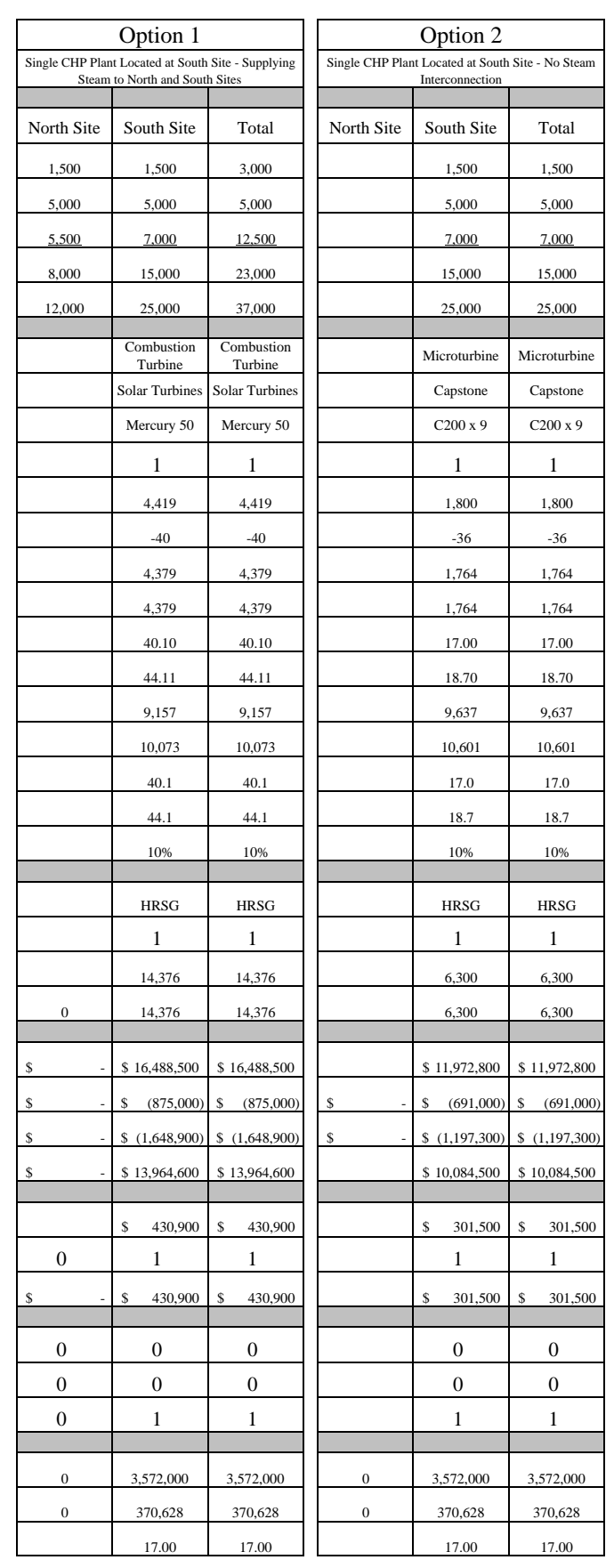

\begin{tabular}{|c|c|c|}
\hline \multicolumn{3}{|c|}{ Option 3} \\
\hline \multicolumn{3}{|c|}{$\begin{array}{l}\begin{array}{l}\text { Single CHP Plant Located a S South Site - No Steam } \\
\text { Interconnection }\end{array} \\
\end{array}$} \\
\hline \multirow{24}{*}{ North Site } & South Site & Total \\
\hline & 1,500 & 1,500 \\
\hline & 5,000 & 5,000 \\
\hline & 7,000 & 7,000 \\
\hline & 15,000 & 15,000 \\
\hline & 25,000 & 25,000 \\
\hline & $\begin{array}{l}\begin{array}{c}\text { Reciprocating } \\
\text { Engine }\end{array}\end{array}$ & $\begin{array}{l}\text { Reciprocating } \\
\text { Ennine }\end{array}$ \\
\hline & GE & GE \\
\hline & $\begin{array}{l}\text { Jenbacher JMS } \\
416\end{array}$ & $\begin{array}{l}\text { Jenbacher JMS } \\
4616\end{array}$ \\
\hline & 2 & 2 \\
\hline & 1,137 & 1,137 \\
\hline & -23 & -23 \\
\hline & 1,114 & 1,114 \\
\hline & 2,229 & 2,229 \\
\hline & 9.78 & 9.78 \\
\hline & 10.75 & 10.75 \\
\hline & 8,774 & 8,774 \\
\hline & 9,651 & 9,651 \\
\hline & 19.6 & 19.6 \\
\hline & 21.5 & 21.5 \\
\hline & $10 \%$ & $10 \%$ \\
\hline & HRSG & HRSG \\
\hline & 2 & 2 \\
\hline & 3,552 & 3,552 \\
\hline 0 & 7,104 & 7,104 \\
\hline & $\$ 10,032,100$ & \begin{tabular}{|l} 
S $10,032,100$ \\
\end{tabular} \\
\hline$\$$ & $\$(529,065)$ & $\$(529,065)$ \\
\hline$\$$ & $\$(1,003,200)$ & $\$(1,003,200)$ \\
\hline$\$$ & \$ $8,499,835$ & S 8,499,835 \\
\hline$\$$ & $\$ \quad 137,100$ & $\begin{array}{ll}\$ & 137,100 \\
\end{array}$ \\
\hline 0 & 2 & 2 \\
\hline$\$$ & $\$ \quad 274,200$ & $\begin{array}{ll}\text { S } & 274,200 \\
\end{array}$ \\
\hline 0 & 0 & 0 \\
\hline 0 & 0 & 0 \\
\hline 0 & 1 & 1 \\
\hline 0 & $3,572,000$ & $3,572,000$ \\
\hline 0 & 370,628 & 370,628 \\
\hline & 17.00 & 17.00 \\
\hline
\end{tabular}




\begin{tabular}{l} 
Gas Price SMMBtu [1] \\
January \\
February \\
March \\
April \\
May \\
June \\
July \\
August \\
September \\
October \\
November \\
December \\
\hline Average
\end{tabular}

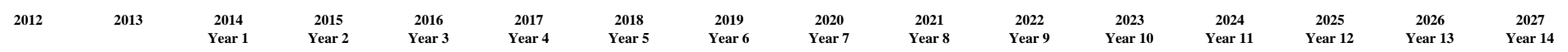

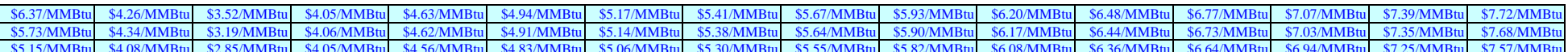

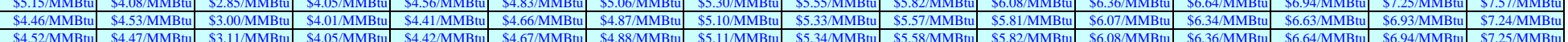

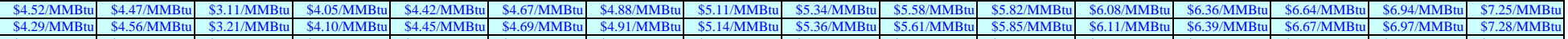

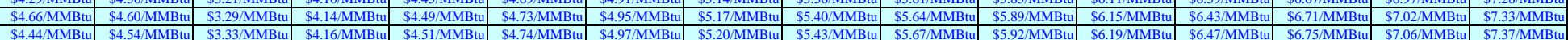

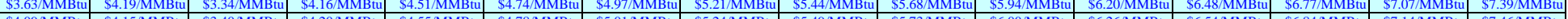

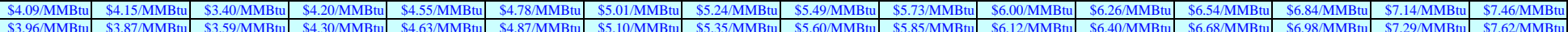

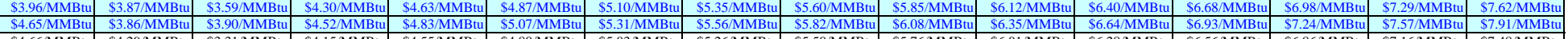

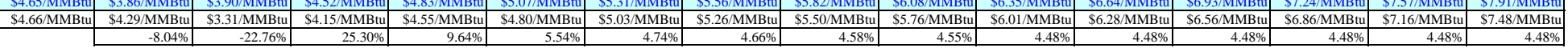

On Peak Energy (\$MWh) [2]

Jebruary

April
May
June

July

August
September

September

November

$\frac{\text { December }}{\text { Average On Peak (\$MWh) }}$

\begin{tabular}{|c|c|c|c|c|c|c|c|c|c|c|c|c|c|c|c|}
\hline $6.91 / \mathrm{MWh}$ & 1 & $\mathrm{Wh}$ & III & (N) & GWh & 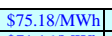 & $.91 / \mathrm{MWh}$ & $39 / \mathrm{MWh}$ & 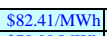 & 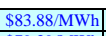 & $\$ 85.68 / \mathrm{MWh}$ & $\$ 86.77 / \mathrm{MWh}$ & \$899.39/MWh & \$91.89/MWh & 994.58 \\
\hline $84 / \mathrm{MWh}$ & $\$ 67.60 / \mathrm{MWh}$ & 4.98/MWh & $\$ 66.25 / \mathrm{MWh}$ & $\$ 69.43 / \mathrm{MWh}$ & $\$ 69.52 \mathrm{MWh}$ & $1.16 / \mathrm{MWh}$ & & $\$ 76.09 / \mathrm{MWh}$ & wn & $\$ 79.39 / \mathrm{MWh}$ & & & $884.61 / \mathrm{MWh}$ & & \\
\hline $4.20 / \mathrm{MV}$ & $\begin{array}{l}865.86 / 1 \\
5077070\end{array}$ & & $\$ 63.78 / \mathrm{MWh}$ & $\$ 66.85 / \mathrm{MWh}$ & $\$ 66.93 / \mathrm{MWh}$ & $\begin{array}{l}868.50 / \mathrm{MWh} \\
8.159\end{array}$ & $\$ 71.91 / \mathrm{MWh}$ & $\begin{array}{l}\$ 73.25 \\
c .20\end{array}$ & MWh & 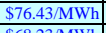 & MWh f & $\overline{\mathrm{Nh}}$ & $1.46 / \mathrm{MWh}$ & $3.73 / \mathrm{MWh}$ & $18 \mathrm{MWh}$ \\
\hline $6.60 / \mathrm{MWh}$ & & $\$ 55.16 /$ & $\$ 56.9$ & & & \$61.15/MWh & $\$ 64.19 / \mathrm{MWh}$ & & & $\$ 68.23 / \mathrm{MWh}$ & & & & & $\overline{\mathrm{nWh}}$ \\
\hline MWh & $\frac{859.19 / \mathrm{MWh}}{\$ 6631 \mathrm{MWh}}$ & $\frac{\$ 54.87 / \mathrm{MWh}}{\$ 55899 \mathrm{MW}}$ & $\frac{856.73 / \mathrm{MWh}}{\$ 66.09 \mathrm{MWh}}$ & $\frac{859.46 / \mathrm{MWh}}{86.91 \mathrm{MWW}}$ & $\frac{\$ 59.54 / \mathrm{MWh}}{\$ 66.00 \mathrm{MWh}}$ & 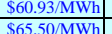 & 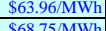 & $\$ 65.16 / \mathrm{MWh}$ & $\$ 66.80 / \mathrm{MWh}$ & $\frac{\$ 67.99 / \mathrm{MWh}}{S 730}$ & 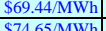 & 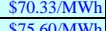 & $\$ 72.46 / \mathrm{MWh}$ & $\$ 874.48 / \mathrm{MWh}$ & $\frac{6.66 / \mathrm{MWh}}{200(5)}$ \\
\hline & & & & & & & & & & & & & & & 40MWh \\
\hline & & & & & & & & & & & & & & & \\
\hline & $\frac{M v}{14}$ & 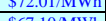 & $\frac{8 t}{S 7}$ & 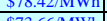 & 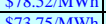 & 5010 & $\frac{38.453 / 1}{9620}$ & 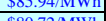 & 380 & 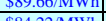 & $\frac{S 91.59}{9032}$ & $\frac{S 9.216}{9071}$ & $x_{2}$ & & \\
\hline 866.8 & & 9641 & & & 570 & & & $38 / M$ & & & & & $\overline{41}$ & $\$ 8844 \sqrt{1}$ & $\frac{1}{4}$ \\
\hline & & & & & & & & & & & & & & & \\
\hline & & & & & & & & & & & & & & & \\
\hline & $\$ 68.25 / \mathrm{N}$ & $\$ 64.29 / \mathrm{MWh}$ & $\$ 66.74 / \mathrm{MWh}$ & $\$ 69.94 / \mathrm{MWh}$ & $\$ 70.04 / \mathrm{MWh}$ & IWh & S75.24/MWh & $\$ 876.65 \mathrm{MWh}$ & $\$ 57.58 \mathrm{MWh}$ & S79.98/MWh & $\$ 81.69 \mathrm{MWh}$ & $\begin{array}{l}\text { S82.74/MWh } \\
\end{array}$ & MWh & $\$ 87.61 \mathrm{MWh}$ & $590.18 \mathrm{MWh}$ \\
\hline
\end{tabular}

Off Peak Energy (S/MWh) [2]

January
February

April
May

June

August
September

October
Novemb

Dovember

December

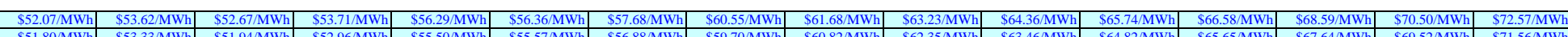

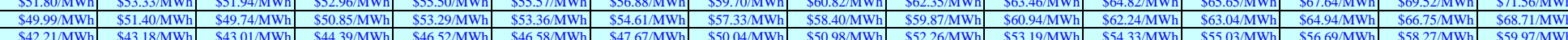

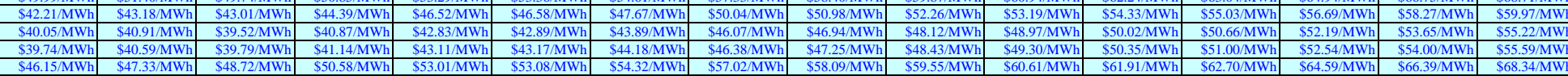

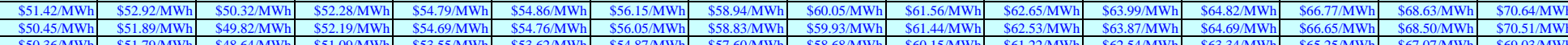

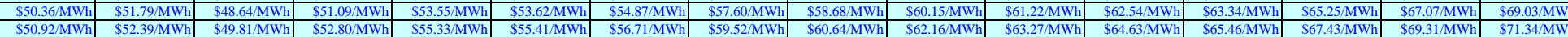

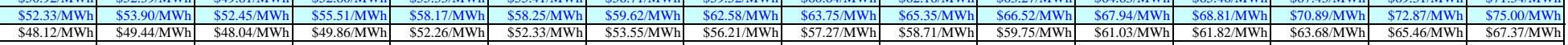

[1] Source: Correlation to Henry Hub futures pricing.
[2] Source: SMUD forecast, prior study. 


\begin{tabular}{|c|c|c|c|c|c|c|c|c|c|c|c|c|c|}
\hline & $\frac{-J a n u a r y}{31}$ & February & $\frac{\text { March }}{31}$ & $\frac{\text { April }}{30}$ & $\frac{\mathrm{Mav}}{31}$ & June & $\frac{\text { July }}{31}$ & $\begin{array}{l}\text { August } \\
11\end{array}$ & $\begin{array}{l}\text { September } \\
\end{array}$ & October & November & December & $\begin{array}{l}\text { Total } \\
365\end{array}$ \\
\hline Energy Consumption (kWh) & $\frac{31}{1,806,040}$ & $\begin{array}{c}28 \\
1,654,580\end{array}$ & $\frac{31}{1,938,140}$ & $\frac{30}{1,874,520}$ & $\frac{31}{2,046,370}$ & $\frac{30}{2,063,900}$ & $\frac{31}{2,224,920}$ & $\frac{31}{2,237,190}$ & $\frac{30}{2,192,432}$ & \begin{tabular}{c|}
31 \\
$2,064,750$
\end{tabular} & $\frac{30}{1,873,760}$ & $\frac{31}{1,772,930}$ & $\begin{array}{c}365 \\
23,749,532\end{array}$ \\
\hline Peak Den & 3,104 & 3,148 & 3,331 & 3,329 & 3,430 & 3,763 & 3,822 & 3,845 & 3,894 & 3,549 & 3,328 & 3,047 & 3,894 \\
\hline Average & 2,427 & 2,462 & 2,605 & 2,604 & 2,750 & 2,867 & 2,990 & 3,007 & 3,045 & 2,775 & 2,602 & 2,383 & 2,710 \\
\hline Min Demand $(\mathrm{kW})$ & 1,751 & 1,776 & 1,879 & 1,878 & 2,071 & 1,970 & 2,159 & 2,169 & 2,196 & 2,002 & 1,877 & 1,719 & 1,719 \\
\hline Load Factor (\%) & $78.20 \%$ & $78.20 \%$ & $78.20 \%$ & $78.20 \%$ & $80.18 \%$ & $76.17 \%$ & $78.25 \%$ & $78.20 \%$ & $78.20 \%$ & $78.20 \%$ & $78.20 \%$ & $78.20 \%$ & $69.63 \%$ \\
\hline Daytim & 3,104 & 3,148 & 3,331 & P & 3,430 & 3,763 & 3,822 & $\begin{array}{r}3,845 \\
3,276\end{array}$ & 3,894 & 3,549 & 3,328 & 3,047 & 3,466 \\
\hline Daytime Energy ( $\mathrm{kWh}$ ) & 1,154,715 & 1,057,877 & 1,239,175 & 1,1988,499 & 1,276,086 & 1,354,729 & 1,421,617 & $1,430,376$ & 1,401, & 1,320,125 & 1,198,013 & $1,133,546$ & ,186,516 \\
\hline $\mid \begin{array}{l}\text { Nighttime Load }(\mathrm{kW}) \\
\text { Nighttime Energy }(\mathrm{kWh})\end{array}$ & $\begin{array}{r}1,751 \\
651,325\end{array}$ & $\begin{array}{c}1,776 \\
596,703\end{array}$ & $\begin{array}{r}1,879 \\
698,965\end{array}$ & $\begin{array}{r}1,878 \\
676,021\end{array}$ & $\begin{array}{r}2,071 \\
770,284\end{array}$ & $\begin{array}{r}1,970 \\
709,171\end{array}$ & $\begin{array}{r}2,159 \\
803,303\end{array}$ & $\begin{array}{r}2,169 \\
806,814\end{array}$ & $\begin{array}{r}2,196 \\
790,672\end{array}$ & $\begin{array}{r}2,002 \\
744,625\end{array}$ & $\begin{array}{r}1,877 \\
675,747\end{array}$ & $\begin{array}{r}1,719 \\
639,384\end{array}$ & $\begin{array}{r}1,954 \\
3,563,016\end{array}$ \\
\hline Total Energy (kWh) & $1,806,040$ & $1,654,580$ & $1,938,140$ & $1,874,520$ & $2,046,370$ & $2,063,900$ & $2,224,920$ & $2,237,190$ & 2,192,432 & $2,064,750$ & $1,873,760$ & $1,772,930$ & $23,749,5$ \\
\hline
\end{tabular}

\begin{tabular}{|c|c|c|c|c|c|c|c|c|c|c|c|c|c|}
\hline STEAM LOAD SUMMARY & $\underline{\text { January }}$ & $\underline{\text { February }}$ & $\underline{\text { March }}$ & April & $\underline{\underline{M a y}}$ & $\underline{\text { June }}$ & $\underline{\text { Julv }}$ & August & $\underline{\text { September }}$ & October & $\underline{\text { November }}$ & December & $\underline{\text { Total }}$ \\
\hline \multicolumn{14}{|l|}{ North Site } \\
\hline North Natural Gas (Therms) & $\begin{array}{r}38,086 \\
3809\end{array}$ & $\begin{array}{r}36,124 \\
3612\end{array}$ & $\begin{array}{r}37,454 \\
3744\end{array}$ & 34,796 & 34,866 & $\begin{array}{r}30,282 \\
3022\end{array}$ & 30,596 & $\begin{array}{r}30,095 \\
301\end{array}$ & 28,610 & 33,131 & 36,661 & 38,086 & $\begin{array}{r}408,787 \\
4079\end{array}$ \\
\hline North Natural Gas (MMBtu) & 3,809 & 3,612 & 3,745 & 3,480 & 3,487 & 3,028 & 3,060 & 3,010 & 2,861 & 3,313 & 3,666 & 3,809 & 40,879 \\
\hline Existing Boiler Efficiency (\%) & $85 \%$ & $85 \%$ & $85 \%$ & $85 \%$ & $85 \%$ & $85 \%$ - & $85 \%$ & $85 \%$ & $85 \%$ & $85 \%$ & $85 \%$ & $85 \%$ & $85 \%$ \\
\hline $\begin{array}{l}\text { Steam Production (MMBtu } \\
\text { Steam Enthalpy (Btu/lb) }\end{array}$ & $\frac{3,237}{1,047}$ & $\begin{array}{l}3,071 \\
1,047\end{array}$ & $\begin{array}{l}3,184 \\
1,047\end{array}$ & 2,958 & $\begin{array}{l}2,964 \\
1,047\end{array}$ & $2,2,574$ & 2,601 & 2,558 & $\begin{array}{l}2,432 \\
1,047\end{array}$ & 2,816 & $\begin{array}{l}3,116 \\
1,047\end{array}$ & $\begin{array}{l}3,237 \\
1,047\end{array}$ & 34,747 \\
\hline Steam Production (lbs) & $3,091,979$ & $2,932,695$ & $\begin{aligned} 1,047 \\
3,040,711\end{aligned}$ & $\begin{aligned} 2,824,898 \\
\end{aligned}$ & $\begin{aligned} 1,047 \\
2,830,573\end{aligned}$ & $\begin{aligned} 1,047 \\
2,458,400\end{aligned}$ & $\begin{array}{r}1,04 / \\
2,483,948\end{array}$ & $\frac{1,047}{2,443,275}$ & $\begin{aligned} 1,32,668 \\
\end{aligned}$ & $\frac{1,047}{2,689,702}$ & $\begin{aligned} 1,047 \\
2,976,266\end{aligned}$ & $\begin{array}{r}1,047 \\
3,091,979\end{array}$ & $\begin{array}{r}1,047 \\
33,187,093\end{array}$ \\
\hline \multicolumn{14}{|l|}{$\begin{array}{l}\text { South Site } \\
\text { quth }\end{array}$} \\
\hline 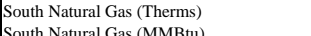 & $\begin{array}{l}88,867 \\
8887\end{array}$ & $\begin{array}{r}84,289 \\
8429\end{array}$ & $\begin{array}{r}87,394 \\
8739\end{array}$ & $\begin{array}{r}81,191 \\
819\end{array}$ & $\begin{array}{l}81,354 \\
8135\end{array}$ & $\begin{array}{l}70,657 \\
7067\end{array}$ & 71,392 & $\begin{array}{l}70,223 \\
7022\end{array}$ & $\begin{aligned} 66,756 \\
666\end{aligned}$ & $\begin{array}{l}77,305 \\
7731\end{array}$ & 85,541 & $\begin{array}{l}88,867 \\
8887\end{array}$ & $\begin{array}{c}953,836 \\
95384\end{array}$ \\
\hline 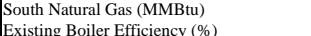 & 8,887 & $\frac{8,429}{850 \%}$ & $\frac{8,739}{850 \% \mathrm{D}}$ & 8,119 & 8,135 & $\begin{array}{l}7,066 \\
8509 \\
\end{array}$ & $\begin{array}{l}7,139 \\
850 \%\end{array}$ & 7,022 & 6,676 & 7,731 & 8,554 & 8,887 & 95,384 \\
\hline $\begin{array}{l}\text { Existing Boiler Efficiency (\%) } \\
\text { Stream Production }\end{array}$ & $\frac{85 \% \mid}{7554}$ & $85 \% \mid$ & $85 \%$ & $85 \%$ & $85 \%$ & $85 \%$ & $85 \%$ & $85 \%$ & $\frac{85 \%}{5671}$ & $85 \% \mid$ & $85 \%$ & $85 \%$ & $85 \%$ \\
\hline $\begin{array}{l}\text { Steam Production (MMBBu) } \\
\text { Steam Enthalpy (Btu/lb) }\end{array}$ & $\frac{7,5,54}{1,147}$ & $\begin{array}{l}7,165 \\
1,147\end{array}$ & $\begin{array}{l}7,428 \\
1,147\end{array}$ & $\begin{array}{l}6,901 \\
1,147\end{array}$ & $\begin{array}{l}6,915 \\
1,147\end{array}$ & $\begin{array}{l}6,006 \\
1,147\end{array}$ & $\begin{array}{l}6,068 \\
1,147\end{array}$ & $\begin{array}{l}5,969 \\
1,147\end{array}$ & $\begin{array}{l}5,674 \\
1,147\end{array}$ & $\begin{array}{l}6,571 \\
1,147\end{array}$ & $\begin{array}{l}7,271 \\
1,147\end{array}$ & $\begin{array}{l}7,554 \\
1,147\end{array}$ & $\begin{array}{c}81,076 \\
1,147\end{array}$ \\
\hline Steam Production (lbs) & $6,585,618$ & $6,246,359$ & $6,476,422$ & $\begin{array}{l}6,016,762 \\
\end{array}$ & $6,028,849$ & $5,236,156$ & $5,290,572$ & $5,203,942$ & $4,947,059$ & $5,728,807$ & $6,339,162$ & \begin{tabular}{|c|c|}
$6,585,618$ \\
\end{tabular} & $70,685,326$ \\
\hline Total Natural Gas (' & $126,953 \mid$ & $120,413 \mid$ & $124,848 \mid$ & $115,987 \mid$ & $116,220 \mid$ & 100,939 & 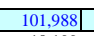 & $100,318 \mid$ & $95,366 \mid$ & 110,436 & 122,202 & 126,953 & $1,362,623$ \\
\hline Total Natural Gas ( & 12,695 & 12,041 & 12,485 & 11,599 & 11,622 & 10,094 & 10,199 & 10,032 & 9,537 & 11,044 & 12,220 & 12,695 & 136,262 \\
\hline $\begin{array}{l}\text { Total Steam Demand (MMBtur } \\
\text { Total Steam Demand (lbs) }\end{array}$ & $\begin{array}{r}10,791 \\
9,677,596\end{array}$ & $\begin{array}{r}10,235 \\
9,179,054\end{array}$ & $\begin{array}{r}10,612 \\
9,517,133\end{array}$ & $\begin{array}{r}9,859 \\
8,841,661\end{array}$ & $\begin{array}{r}9,879 \\
8859,422\end{array}$ & $\begin{array}{r}8,580 \\
7694555\end{array}$ & $\begin{array}{r}8,669 \\
7774,520\end{array}$ & $\begin{array}{r}8,527 \\
7647217\end{array}$ & $\begin{array}{r}8,106 \\
269727\end{array}$ & $\begin{array}{r}9,387 \\
8,418509\end{array}$ & $\begin{array}{r}10,387 \\
9315,49\end{array}$ & $\begin{array}{r}10,791 \\
667596\end{array}$ & $\begin{array}{r}115,823 \\
0382,419\end{array} \mid$ \\
\hline Iotal Steam Demand (Ibs) & & & & & & & & & & & & & \\
\hline
\end{tabular}

4.1 CHP DISPATCH SUMMARY

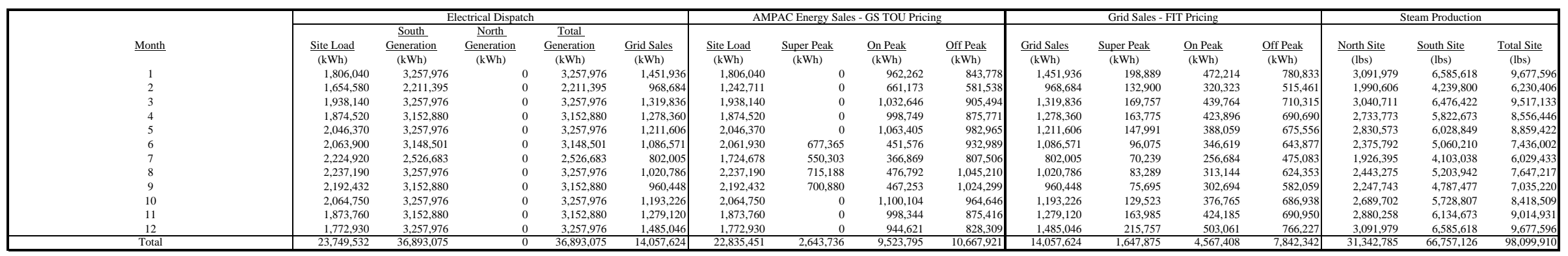




\begin{tabular}{|c|c|c|c|c|c|c|c|c|c|c|c|c|c|c|}
\hline & & $\underline{\text { Jan }}$ & $\underline{\text { Feb }}$ & Mar & Apr & $\underline{\text { May }}$ & $\underline{\text { Jun }}$ & $\underline{\text { Jul }}$ & Aug & $\underline{\text { Sep }}$ & $\underline{\mathrm{Oct}}$ & $\underline{\text { Nov }}$ & Dec & $\underline{2012}$ \\
\hline$\frac{\text { Electric Generation Capacity }}{\text { North CHP Plant Generation Capacity }(k W)}$ & & & & & & & & & & & & & & \\
\hline $\begin{array}{l}\text { North CHP Plant Generation Capacity }(\mathrm{kW}) \\
\text { South CHP Plant Generation Capacity }(\mathrm{kW})\end{array}$ & & $\begin{array}{r}0 \\
4,379\end{array}$ & $\begin{array}{r}0 \\
4,379\end{array}$ & $\begin{array}{r}0 \\
4,379\end{array}$ & $\begin{array}{r}0 \\
4,379\end{array}$ & 4,379 & $\begin{array}{r}0 \\
4,379\end{array}$ & 4,379 & $\begin{array}{r}0 \\
4,379\end{array}$ & $\begin{array}{r}0 \\
4,379\end{array}$ & $\begin{array}{r}0 \\
4,379\end{array}$ & $\begin{array}{r}0 \\
4,379\end{array}$ & $\begin{array}{r}4,379 \\
\end{array}$ & 4,379 \\
\hline Total Generation Capacity $(\mathrm{kW})$ & & 4,379 & 4,379 & 4,379 & 4,379 & 4,379 & 4,379 & 4,379 & 4,379 & 4,379 & 4,379 & 4,379 & 4,379 & 4,379 \\
\hline $\begin{array}{l}\text { Electric Generation Energy } \\
\text { North CHP Plant Generation }(k \text { Wh) }\end{array}$ & & & & & & & & & & & & & & \\
\hline $\begin{array}{l}\text { North CHP Plant Generation }(\mathrm{kWh}) \\
\text { South CHP Plant Generation }(\mathrm{kWh})\end{array}$ & & $\begin{aligned} 0 \\
3,257,976\end{aligned}$ & $\begin{array}{r}11,395 \\
-10\end{array}$ & $\begin{array}{r}0 \\
3,257,976\end{array}$ & $\begin{array}{r}0 \\
3,152,880\end{array}$ & $\begin{array}{r}0 \\
3,257,976\end{array}$ & $\begin{array}{r}0 \\
3,148,501\end{array}$ & $\begin{array}{r}0 \\
2,526,683\end{array}$ & $\begin{array}{r}0 \\
3,257,976\end{array}$ & $\begin{array}{r}0 \\
3,152,880\end{array}$ & $\begin{array}{r}0 \\
3,257,976\end{array}$ & $\begin{array}{r}0 \\
3,152,880\end{array}$ & $3,257,976$ & 6,893,075 \\
\hline Total CHP Plant Generation (kWh) & & $3,257,976$ & $2,211,395$ & $3,257,976$ & $3,152,880$ & $3,257,976$ & $3,148,501$ & $2,526,683$ & $3,257,976$ & $3,152,880$ & $3,257,976$ & $3,152,880$ & $3,257,976$ & $36,893,075$ \\
\hline$\underline{\text { Total Energy Sales }}$ & & & & & & & & & & & & & & \\
\hline AMPAC Energy Sales $(\mathrm{kWh})$ & & $1,806,040$ & $1,242,711$ & $1,938,140$ & $1,874,520$ & $2,046,370$ & $2,061,930$ & $1,724,678$ & $2,237,190$ & $2,192,432$ & $2,064,750$ & $1,873,760$ & $1,772,930$ & $22,835,451$ \\
\hline $\begin{array}{l}\text { SMUD Grid Energy Sales }(\mathrm{kWh}) \\
\text { Total CHP Plant Generation (kWh) }\end{array}$ & & $\frac{1,451,936}{3,257,976}$ & $\begin{array}{r}968,684 \\
2,211,395\end{array}$ & $\begin{array}{l}1,319,836 \\
3,257,976\end{array}$ & $\begin{array}{l}1,278,360 \\
3,152,880\end{array}$ & $\begin{array}{l}\frac{1,211,606}{3,257,976} \\
3\end{array}$ & $\begin{array}{l}1,086,571 \\
3,148,501\end{array}$ & $\begin{array}{r}802,005 \\
2,526,683\end{array}$ & $\frac{1,020,786}{3,257,976}$ & $\begin{array}{r}960,448 \\
3,152.880\end{array}$ & $\begin{array}{l}1,193,226 \\
3,257,976\end{array}$ & $\begin{array}{r}1,279,120 \\
3,152,880\end{array}$ & \begin{tabular}{l|l}
$1,485,046$ \\
$3,257,976$
\end{tabular} & $\begin{array}{l}\frac{14,057,624}{36,893,075} \\
\end{array}$ \\
\hline AMPAC Energy Sales & & & & & & & & & & & & & & \\
\hline Super Peak Energy Sales (kWh) & & & 0 & 0 & 0 & & 677,365 & 550,303 & 715,188 & 700,880 & 0 & 0 & 0 & $2,643,736$ \\
\hline On Peak Energy Sales (kWh) & & 962,262 & 661,173 & $1,032,646$ & 998,749 & $1,063,405^{\llcorner}$ & 451,576 & 366,869 & 476,792 & 467,253 & $1,100,104$ & 998,344 & 944,621 . & $9,523,795$ \\
\hline Off Peak Energy Sales $(k W h)$ & & 843,778 & 581,538 & 905,494 & 875,771 & 982,965 & 932,989 & 807,506 & $1,045,210$ & $1,024,299$ & 964,646 & 875,416 & 828,309 & $10,667,921$ \\
\hline AMPAC Energy Sales (kWh) & & $1,806,040$ & $1,242,711$ & $1,938,140$ & $1,874,520$ & $2,046,370$ & $2,061,930$ & $1,724,678$ & $2,237,190$ & $2,192,432$ & $2,064,750$ & $1,873,760$ & $\begin{array}{l}, 772,930 \\
\end{array}$ & $\frac{22,835,451}{22}$ \\
\hline SMUI & & & & & & & & & & & & & & \\
\hline $\begin{array}{l}\text { Super P } \\
\text { Po Pel }\end{array}$ & $\$$ & & & $-\quad \$$ & $-\quad \$$ & & $0.1203 \$$ & $0.1203 \quad \$$ & $0.1203 \$$ & $0.1203 \$$ & \$ & $-\$$ & & 0.1203 \\
\hline & $\$$ & $\begin{array}{l}0.0833 \mathrm{\$} \\
0.0699\end{array}$ & $\begin{array}{l}0.0883 \text { \$ } \\
0.0699 \$\end{array}$ & $\begin{array}{ll}0.0883 & \$ \\
0.0999 & \$\end{array}$ & $\begin{array}{l}0.0883 \text { \$ } \\
0.0699\end{array}$ & $\begin{array}{ll}0.0883 & \$ \\
0.0699 & \$\end{array}$ & $\begin{array}{ll}0.1057 & \$ \\
0.083 & \$\end{array}$ & 0.1057 \$ & $0.1057 \$$ & $0.1057 \$$ & $\begin{array}{ll}0.0883 & \$ \\
0.0999 & \$\end{array}$ & $0.0883 \$$ & 0.0883 & 0.0915 \\
\hline Off Peak Energy Rate (\$/kWh) & 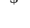 & $0.0099 \$$ & & $0.0699 \$$ & 0.0699 s & & $0.0863 \$$ & $0.0863 \$$ & $0.0863 \$$ & $0.0863 \$$ & $0.0699 \$$ & $0.0699 \$$ & 0.0699 & 0.0758 \\
\hline AMPAC & & & & & & & & & & & & & & \\
\hline Super P & $\$$ & & & & $\therefore \$$ & $-\$$ & $\begin{array}{l}81,500 \$ \\
1770-\$\end{array}$ & $66,200 \$$ & $\begin{array}{l}86,000 \$ \\
5000\end{array}$ & $84,300 \$$ & & $-\$$ & & 318,000 \\
\hline $\begin{array}{l}\text { On Peak Energy Revenues (\$) } \\
\text { Off Peak Ferga Revenues }\end{array}$ & $\$$ & $85,000 \$$ & $58,400 \$$ & $91,200 \$$ & $88,200 \$$ & $93,900 \$$ & $47,700 \$$ & $38,800 \$$ & $50,400 \$$ & $\begin{array}{ll}49,400 & \$ \\
& \end{array}$ & $97,100 \$$ & $88,200 \$$ & 83,400 & 871,700 \\
\hline$\frac{\text { Off Peak Energy Revenues }}{\text { AMPAC Energy Revenues }(\mathbf{S})}$ & $\$$ & $\begin{aligned} 59,000 & \$ \\
14400 & \$\end{aligned}$ & $\begin{array}{ll}40,600 & \$ \\
99 & \$\end{array}$ & $\begin{array}{r}63,300 \$ \\
15450-\$\end{array}$ & $61,200 \$$ & $68,700 \$$ & $80,500 \$$ & $\begin{array}{r}69,700 \$ \\
\end{array}$ & $\begin{array}{ll}90,200 & \$ \\
20,600 & \$\end{array}$ & $88,400 \$$ & 67,400 \$ & $61,200 \$$ & 57,900 & 808,100 \\
\hline AMPAC Energy Revenues (\$) & & & & & 149,400 \$ & $162,600 \$$ & $209,700 \$$ & & $226,600 \$$ & $222,100 \$$ & $164,500 \$$ & $149,400 \$$ & 141,300 & 1,997,800 \\
\hline SMUD Grid Energy Sa & & & & & & & & & & & & & & \\
\hline $\begin{array}{l}\text { Super Peak Energy Sales ( } \\
\text { On Peak Energy Sales (kW }\end{array}$ & & $\begin{array}{l}198,889 \\
472,214\end{array}$ & $\begin{array}{l}132,900 \\
320,323\end{array}$ & $\begin{array}{l}\begin{array}{l}169,577 \\
439,764\end{array} \\
4\end{array}$ & $\begin{array}{l}1636,775 \\
423,896\end{array}$ & $\begin{array}{l}14,991 \mathrm{~L} \\
388,059\end{array}$ & & $\frac{0,239}{2039}, 0,0$ & $\frac{83}{313}$ & & $\begin{array}{l}12,523 \\
376,765\end{array}$ & $\begin{array}{l}162,985 \\
424,185\end{array}$ & 503,061 & $\left.\begin{array}{l}1,6677,85 \\
4,567,408\end{array}\right]$ \\
\hline Off Peak Energy Sales (kV & & 780,833 & 515,461 & 710,315 & 690,690 & 675,556 & 643,877 & 475,083 & 624,353 & 582,059 & 686,938 & 690,950 & 766,227 & $7,842,342$ \\
\hline SMUD Grid Energy Sales (kWh) & & $1,451,936$ & 968,684 & $1,319,836$ & $1,278,360$ & $1,211,606$ & $1,086,571$ & 802,005 & $1,020,786$ & 960,448 & $1,193,226$ & $1,279,120$ & $\begin{array}{l}1,485,046 \\
\end{array}$ & $14,057,624$ \\
\hline$\underline{S M U}$ & & & & & & & & & & & & & & \\
\hline Super & $\$$ & $0.0606 \$$ & $0.0606 \$$ & $0.0505 \$$ & $15 \$$ & $5 \$ \$$ & $5 \$$ & $0.2235 \$$ & $0.2235 \$$ & $0.2235 \$$ & $0.0606 \$$ & $0.0606 \$$ & 0.0606 & 0.0899 \\
\hline On Pe & $\$$ & $0.0551 \$$ & $0.0551 \$$ & $0.0486 \$$ & $6 \$$ & $36 \$$ & & 3 & $0.0583 \$$ & $0.0583 \$$ & $0.0551 \$$ & $0.0551 \$$ & 51 & 0.0542 \\
\hline Off Peak Energy Rate (\$/kWh) & $\$$ & $0.0433 \$$ & $0.0433 \$$ & $0.0374 \$$ & $0.0374 \$$ & $0.0374 \$$ & $0.0499 \$$ & $0.0499 \$$ & $0.0499 \$$ & $0.0499 \$$ & $0.0433 \$$ & $0.0433 \$$ & 0.0433 & 0.0437 \\
\hline SMUD & & & & & & & & & & & & & & \\
\hline & $\$$ & $12,100 \$$ & $8,100 \$$ & $8,600 \$$ & $8,300 \$$ & $\$$ & $21,500 \quad \$$ & $15,700 \quad \$$ & & 16,900 \$ & $7,900 \$$ & $9,900 \$$ & 13,100 & 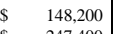 \\
\hline & $\$$ & $26,000 \$$ & $17,600 \$$ & $21,400 \$$ & $20,600 \$$ & & & & & & & $23,400 \$$ & & 247 \\
\hline Off $\mathrm{P}$ & $\$$ & $33,800 \quad \$$ & $22,300 \mathrm{~s}$ & $\mathrm{~s}$ & $25,800 \mathrm{~s}$ & & & $0 \mathrm{~s}$ & & $0 s$ & $29,800 \mathrm{~s}$ & $29,900 \$$ & 33,200 & 342,800 \\
\hline SMUD Grid Energy Revenues (\$) & $\$$ & $71,900 \$$ & $48,000 \$$ & $56,600 \$$ & $54,700 \$$ & 51,700 \$ & $73,800 \quad \$$ & $54,400 \$$ & $\begin{array}{ll}68,000 & \$\end{array}$ & $\begin{array}{ll}63,600 & \$ \\
\end{array}$ & $\begin{array}{ll}58,500 \quad \$ \\
\end{array}$ & $63,200 \$$ & 74,000 & 738,400 \\
\hline & & & & & & & & & & & & & & \\
\hline & $\$$ & $144,000 \quad \$$ & $99,000 \$$ & $154,500 \$$ & $149,400 \quad \$$ & $162,600 \$$ & $209,700 \$$ & $174,700 \quad \$$ & 226,600 & $\begin{array}{ll}222,100 & \$ \\
\end{array}$ & 164,500 & $149,400 \$$ & 141,30 & \begin{tabular}{ll|l|l|l}
$, 997,800$ \\
\end{tabular} \\
\hline & $\$$ & $71,900 \$$ & $48,000 \$$ & $56,600 \$$ & 54,700 \$ & $51,700 \$$ & $73,800 \$$ & 54,400 & 68,000 & 63,600 & 58,500 & $63,200 \quad \$$ & 74,000 & 738,400 \\
\hline Total Energy Revenues (\$) & 5 & $215,900 \quad \$$ & $147,000 \$$ & $211,100 \$$ & $204,100 \quad \$$ & $214,300 \$$ & $283,500 \quad \$$ & $229,100 \quad \$$ & $294,600 \quad \$$ & $285,700 \quad \$$ & $223,000 \$$ & $212,600 \quad \$$ & 215,300 & $\begin{array}{ll}\mathbf{\$} & 2,736,200\end{array}$ \\
\hline
\end{tabular}




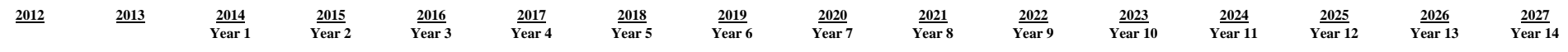

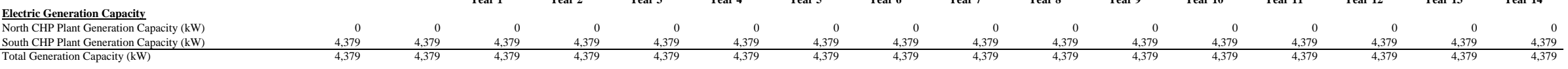

Electric Generation Energy

South CHP Plant Generation $(\mathrm{kWh})$

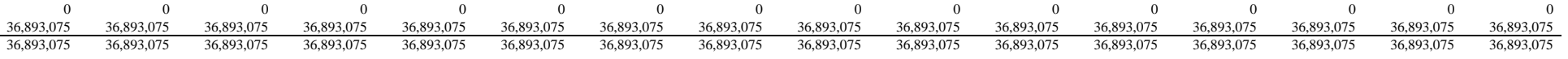

Total Energy Sales

SMUD Grid Energy Sales $(k$ Wh $)$ Total CHP Plant Generation $(k W h)$

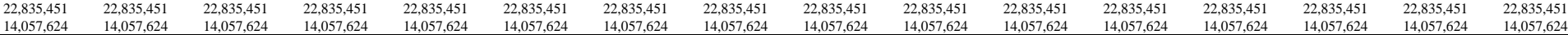

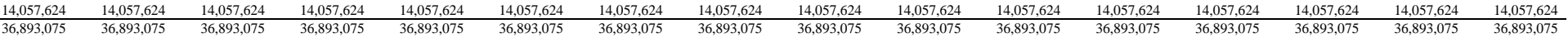

AMPAC Energy Sales Off Peak Energy Sales $(\mathrm{k} W h)$

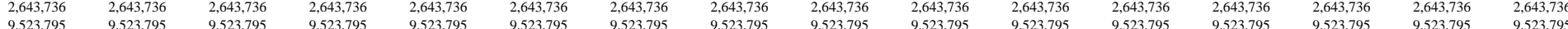

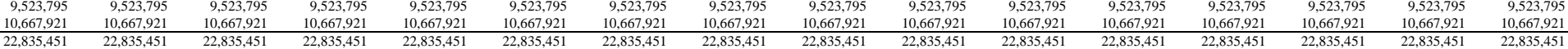

SMUD - GS TOU Rate Super Peak Energy Rate $(\$ / k W h)$
On Peak Energy Rate ( $\$(k W h)$ Off Peak Energy Rate (\$/kWh)

AMPAC Energy Revenues On Peak Energy Revenues (\$)

Off Peak Energy Revenues (\$)

SMUD Grid Energy Sales

Super Peak Energy Sales ( $\mathrm{kWh}$ )

On Peak Energy Sales $(k W h)$
Off Peak Energy Sales $(k W h)$

SMUD Grid Energy Sales (kWh)

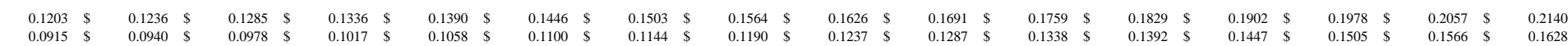

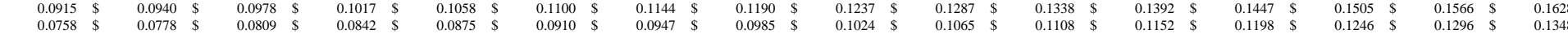

SMUD - FIT Rate

Super Peak Energy Rate ( $\$(\mathrm{kWh})$

Off Peak Energy Rate (\$ $\$$ kWh

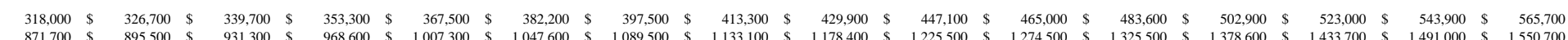

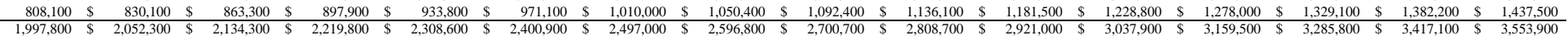

\section{SMUD Grid Energy Revenues}

Super Peak Energy Revenues (\$)

On Peak Energy Revenues (\$)
Off Peak Energy Revenues (\$)

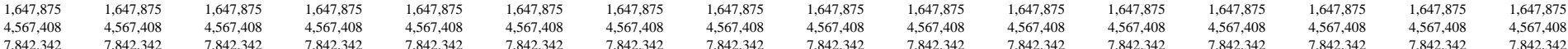

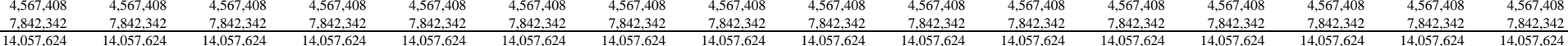

Total CHP Plant Energy Revenues

SMUD Grid Energy Revenues (\$)

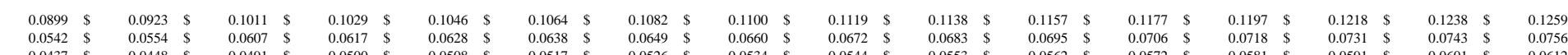

Sotal Energy Revenuus (S)

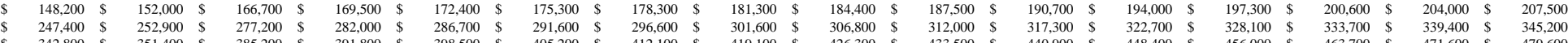

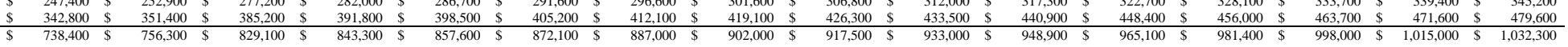


6.0 MONTHLY STEAM REVENUES

\begin{tabular}{|c|c|c|c|c|c|c|c|c|c|c|c|c|c|}
\hline & $\underline{\text { Jan }}$ & $\underline{\text { Feb }}$ & Mar & Apr & $\underline{\text { May }}$ & $\underline{\mathrm{Jun}}$ & Jul & Aug & Sep & $\underline{\mathrm{Oct}}$ & Nov & $\underline{\text { Dec }}$ & 2010 \\
\hline $\operatorname{sam}$ Generation Capacity & & & & & & & & & & & & & \\
\hline ppacit & $\begin{array}{l}4,156 \\
8,852\end{array}$ & $\begin{array}{l}4,456 \\
8,852\end{array}$ & $\begin{array}{l}4,156 \\
8,852\end{array}$ & $\begin{array}{l}4,156 \\
8,852\end{array}$ & $\begin{array}{l}4,156 \\
8,852\end{array}$ & $\begin{array}{l}4,156 \\
8,852\end{array}$ & $\begin{array}{l}4,156 \\
8,852\end{array}$ & $\begin{array}{l}4,156 \\
8,852\end{array}$ & $\begin{array}{l}4,56 \\
8,852\end{array}$ & $\begin{array}{l}4,156 \\
8.852\end{array}$ & $\begin{array}{l}4,156 \\
8,852\end{array}$ & $\begin{array}{l}4,156 \\
8,852\end{array}$ & $\begin{array}{l}4,156 \\
8,852\end{array}$ \\
\hline otal Generation Capacity (lbs/hr) & 13,008 & 13,008 & 13,008 & 13,008 & 13,008 & 13,008 & 13,008 & 13,008 & 13,008 & 13,008 & 13,008 & 13,008 & 13,008 \\
\hline \multicolumn{14}{|l|}{$\underline{\text { Steam Generation }}$} \\
\hline $\begin{array}{l}\text { North CHP Plant Steam Gen } \\
\text { South CHP Plant Steam Gen }\end{array}$ & $\begin{array}{l}3,091,979 \\
6,585,618\end{array}$ & $\begin{array}{l}1,990,606 \\
4239800\end{array}$ & $\begin{array}{l}3,040,711 \\
6476,422\end{array}$ & $\begin{array}{l}2,733,773 \\
5822,673\end{array}$ & $\begin{array}{l}2,830,573 \\
6028,849\end{array}$ & $\begin{array}{l}2,375,792 \\
5,060,210\end{array}$ & $\begin{array}{l}1,926,395 \\
4,103038\end{array}$ & $\begin{array}{l}2,247,743 \\
5,203,942\end{array}$ & $\begin{array}{l}2,689,702 \\
4787,477\end{array}$ & $2,689,702$ & $2,880,258$ & $3,091,979$ & $31,589,212$ \\
\hline Total CHP Plant Steam Generation (lbs) & $\frac{9,635,596}{9,67,596}$ & $6,230,406$ & 9,517,133 & $8,556,446$ & $8,859,422$ & $\frac{1,036,202}{7,436,002}$ & $6,029,433$ & $\frac{1,451,684}{7,451}$ & $\frac{4,6,1,479}{7,477,179}$ & $\frac{2,20,067}{8,418,509}$ & $\frac{0,134,0 / 3}{9,014,931}$ & $\frac{2,030,010}{9,677,596}$ & $\frac{00,35,1,20}{98,346,337}$ \\
\hline \multicolumn{14}{|l|}{ North CHP Plant Steam Revenues } \\
\hline North CHP Plant Steam Generation (1t & 091,979 & $1,990,606$ & 040,711 & 733,773 & 2,830,573 & $2,375,792$ & $1,926,395$ & $2,247,743$ & $2,689,702$ & $2,689,702$ & $2,880,258$ & $3,091,979$ & $31,589,212$ \\
\hline Steam Enthalpy $\left(B_{t y} d \mathrm{C}\right.$ & 1,047 & 1,047 & 1,047 & & 1,047 & 1,047 & 1,047 & 1,047 & 1,047 & 1,047 & 1,047 & 1,047 & 1,047 \\
\hline$C$ & 3,237 & 2,084 & 3,184 & 2,862 & 2,964 & 2,487 & 2,017 & 2,353 & 2.816 & 2,816 & & 3,237 & 33,074 \\
\hline & $85 \%$ & $85 \%$ & $85 \%$ & $85 \%$ & $85 \%$ & $85 \%$ & & $85 \%$ & & $85 \%$ & & & $85 \%$ \\
\hline Gate $(S / N$ & $\begin{array}{r}3,809 \\
77 \mathrm{MMBtu}\end{array}$ & $\begin{array}{l}2,452 \\
\text { MMBtu }\end{array}$ & $\begin{array}{r}3,775 \\
5 / \text { MMBtu }\end{array}$ & $\begin{array}{l}3,367 \\
\text { MMBtu }\end{array}$ & $\begin{aligned} 3,487 \\
\text { MMBtu }\end{aligned}$ & $\begin{array}{l}2,926 \\
\text { MMBtu }\end{array}$ & 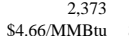 & $\begin{aligned} 2,769 \\
4\end{aligned}$ & $\begin{array}{l}3,313 \\
\text { MMBtu }\end{array}$ & 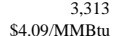 & $\begin{array}{r}3,548 \\
\text { MMBU }\end{array}$ & $\begin{aligned} 3,809 \\
5 / \mathrm{MMBt}\end{aligned}$ & $\begin{aligned} 38,910 \\
67 \text { MMBtu }\end{aligned}$ \\
\hline$\frac{\text { Natural Gas Unit Fuel Price City Gate (S/MMBtu) }}{\text { North CHP Plant Steam Revenue - Gas Credit (\$) }}$ & $\begin{array}{l}7 \mathrm{MMBtu} \\
24,300 \\
\end{array}$ & $\begin{array}{l}\text { 3MMBtu } \\
14,000 \$\end{array}$ & $\begin{array}{ll}5 / \mathrm{MMBtu} \\
19,300 & \$ \\
\end{array}$ & $\begin{array}{ll}\text { MMBBtu } \\
15,000 \text { s }\end{array}$ & MMBtu & $\frac{\text { MMBtu }}{12,600 \$}$ & $\begin{array}{l}\text { 5/MMBtu } \\
11,100 \$\end{array}$ & $\begin{array}{ll}4, \mathrm{MMBtu} \\
12,300 & \mathrm{~s}\end{array}$ & $3 / \mathrm{MMBtu}$ & /MMBtu & $\begin{array}{l}\text { /MMBtu } \\
14,000 \$\end{array}$ & 5/MMBtu & \begin{tabular}{|l|} 
\\
\$
\end{tabular} \\
\hline 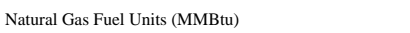 & & & & & & & & 69 & & & 3,548 & & \\
\hline & 2/MMBtu & $\$ 4.02 / \mathrm{MN}$ & $\$ 4.02 / \mathrm{MN}$ & tu & tu & tu & MMBtu & & 3/MMBtu & & & IBtul & \\
\hline $\begin{array}{l}\text { Transport } \\
\text { Transpor }\end{array}$ & \$1.57/MMBtu & $\begin{array}{l}\text { \$1.57/MMBtu } \\
\$ 1 \text {. }\end{array}$ & \$1.57/MMBtu & \$1.28/MMBtu & $\$ 1.28 / \mathrm{A}$ & $\$ 1.28 / \mathrm{MMBtu}$ & \$1.28/MMBtu & $\$ 1.28 /$ & \$1.28/MMBtu & $\$ 1.28$ & MBtu & $\$ 1.57 / \mathrm{MMBtu}$ & \\
\hline 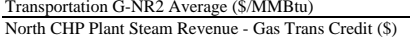 & 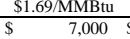 & $\begin{array}{l}\$ 1.76 / \mathrm{MMBtu} \\
\$\end{array}$ & $\begin{array}{l}\$ 1.69 / \mathrm{MMBtu} \\
\$\end{array}$ & MMBtu & $\frac{\$ 1.39 / \mathrm{MMBtu}}{\mathrm{s}, 3,300 \mathrm{~s}}$ & $\frac{\text { MMBtut }}{4,600 \mathrm{~s}}$ & $\frac{\text { MMBtut }}{3,800 \mathrm{~s}}$ & $\begin{array}{l}\text { MMBBu } \\
4,300 \mathrm{~s}\end{array}$ & $\frac{\text { UMBBu }}{5,000 \mathrm{~s}}$ & $\frac{\mathrm{MMBBu}}{5,000}$ & $\frac{1 \mathrm{MBBu}}{6,500 \mathrm{~s}}$ & & $\frac{\mathrm{MMBT}}{65,300}$ \\
\hline NOOI & $3,091,97$ & $1,990,606$ & 3,040 & $2,733,77$ & 2,830, & $2,375,792$ & $1,926,395$ & $2,247,743$ & $2,689,7$ & 2,689 & $2,880,258$ & \begin{tabular}{l|l|l}
$3,091,979$ \\
\end{tabular} & $31,589,212$ \\
\hline & & & & 20 & & $17,200 \$$ & & 16,600 & 17,0 & & & 24,7 & 247,000 \\
\hline $\begin{array}{l}\text { North CHP Plant Steam Revenue (S/1000 lb) } \\
\end{array}$ & $10.1230=5$ & $9.4444 \mathrm{~s}$ & $8.6164 \mathrm{~s}$ & $7.3525 \mathrm{~S}$ & $7.4543 \mathrm{~s}$ & 72307 & $7.7347 \mathrm{~s}$ & 7.3852 & 6.32 & 6.9153 & 7.1 & 7.9884 & 7819 \\
\hline \multicolumn{14}{|l|}{ outh CHP Plant Steam } \\
\hline South CHP Plant Steam Ge & & & & 222, & 28,8 & 5,060, & 103,0 & 03,942 & 887, & 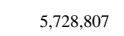 & & & [57,126 \\
\hline & 1,0 & 1,6 & 1,047 & & 1,047 & 然, & $\begin{array}{l}1,047 \\
1,00\end{array}$ & 1,047 & & $\begin{array}{l}2,0 \\
1,0\end{array}$ & & 1,047 & $\begin{aligned} 1,047 \\
1,120\end{aligned}$ \\
\hline & 6,8 & 4,4 & 6, & & & & & 5,44 & & 5,998 & 6,4 & 6,895 & 69,895 \\
\hline & 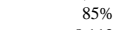 & $03 \%$ & $60 \%$ & & & & & 0 & & & & & $85 \%$ \\
\hline & G 37 , & 5,222 & 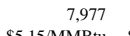 & (1) & & 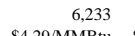 & 年 & 6,410 & 和 & 7,057 & 7,556 & 8,112 & 82,229 \\
\hline & \$6.37/MMBtu & 3/MMBtu & \$5.15/MMBtu & SMMBtu & \$4.52/MMBtu & MMBtu & MMBBtu & IMMBAtu & MMBtu & 9/MMBtu & MMBBtu & & MMBtu \\
\hline South CHP Plant Steam Revenue - Gas Credit (\$) & 51,700 & $29,900 \mathrm{~s}$ & $41,100 \$$ & $32,000 \mathrm{~s}$ & $33,600 \mathrm{~s}$ & $26,700 \$$ & $23,600 \$$ & $28,500 \mathrm{~s}$ & $21,400 \mathrm{~s}$ & 28,900 & 29,900 & 37,700 & 385,000 \\
\hline & & & & & & & & & & & & & 82,22 \\
\hline & $\$ 4.02 / \mathrm{MN}$ & tu & & & & & & & & & & BBtul & \\
\hline Tra & $\$ 1.57 / \mathrm{N}$ & $\$ 1.57 / \mathrm{M}$ & $\$ 1.57 \mathrm{~A}$ & $\$ 1.28$ & $\$ 1.28$ & & & & & & & MBtu & \\
\hline & $\$ 1$ & th & & & & & & & & & & iBtu & ( \\
\hline 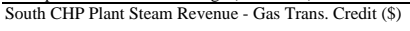 & 13,700 & $9,200 \$$ & $13,500 \$$ & $10,000 \mathrm{~s}$ & 10,300 & $8,800 \$$ & $7,300 \$$ & $9,000 \leqslant$ & $8,400 \mathrm{~s}$ & 9,800 & $12,800 \$$ & 13,700 & 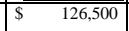 \\
\hline$\overline{\mathrm{Sou}}$ & $6,585,618$ & $4,239,800$ & $6,476,422$ & $5,822,673$ & $6,028,849$ & $5,060,210$ & $4,103,038$ & $5,203,942$ & 4,787, & $5,728,807$ & $6,134,6$ & $6,585,618$ & $66,757,126$ \\
\hline & $\begin{array}{ll}\$ & 65,400 \\
\end{array}$ & $39,100 \$$ & $54,600 \$$ & $42,000 \$$ & $43,900 \leq$ & $\frac{35,500 \$}{30,050}$ & $30,900 \mathrm{~s}$ & $37,500 \mathrm{~s}$ & $29,800 \mathrm{~s}$ & 38,700 & $\frac{42,700 \$}{2,004}$ & $\frac{51,400}{7,000}$ & $\frac{511,500}{1,501}$ \\
\hline $1000 \mathrm{lb})$ & 9.9307 & $9.2221 \$$ & $8.4306 \mathrm{~s}$ & $7.2132 \mathrm{~s}$ & $7.2817 \mathrm{~s}$ & 7.0155 & 7.5310 & 2061 & 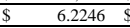 & 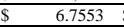 & 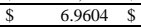 & 7.8049 & \\
\hline \\
\hline & & 18,800 & & 20 & & 17,26 & & 16,600 & 17, & 18,6 & & & \\
\hline & $\frac{1,300}{65,400}$ & 39,100 & $\begin{array}{ll}54,600 & \$\end{array}$ & $000 \mathrm{~s}$ & $3,900 \leqslant s ; s$ & $\frac{1,2,2}{35,50}$ & $\frac{1,400}{30,900}$ & $\frac{10,000}{37,500}$ & $\frac{10,000}{29,800}$ & $\frac{10,000}{38,700}$ & $\frac{2,000}{42,700}$ & $\frac{2,400}{51,400}$ & th11,50 \\
\hline Total CHP Plant Steam Revenue (\$) & $96,700 \quad$ & $57,900 \mathrm{~s}$ & $80,800 \$$ & $62,100 \mathrm{~s}$ & $65,000 s$ & 52,700 s & $45,800 \mathrm{~s}$ & 54,100 & $46,800 \$$ & 57,300 & 63,200 & 76,100 & 758,500 \\
\hline
\end{tabular}




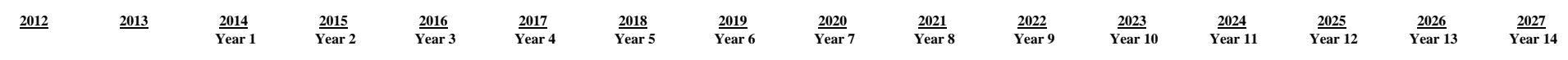

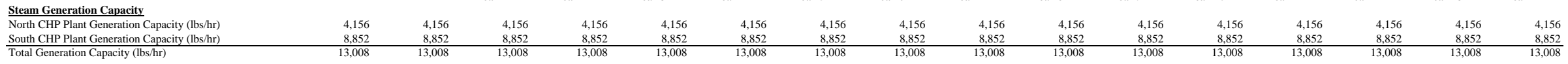

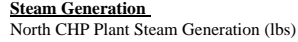
South CHP Plant Steam Generation (bs)

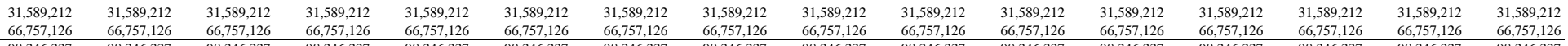
North CHP Plant Steam Revenues North CHP Plant Steam Generation (lbs) Steam Enthalpy (Btu/lb)
North CHP Plant Stear eneration (MMBtu) Natural Gas Fuel Units (MMBtu)

Natural Gas Unit Fuel Price City Gate (S/MMBtu)

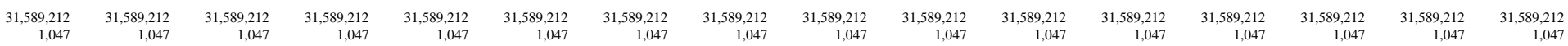

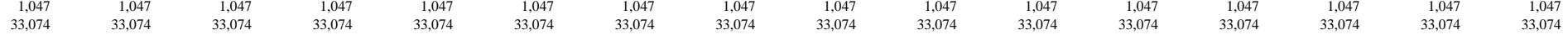

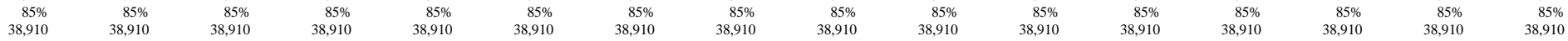

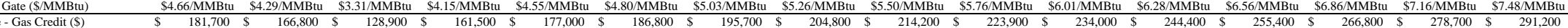
Natural Gas Fuel Units (MMBtu)
Transportation G-NR2 Average (\$MMBtu)

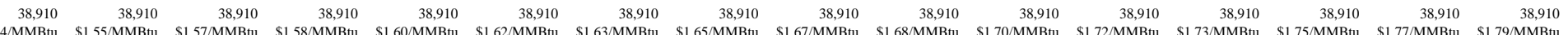

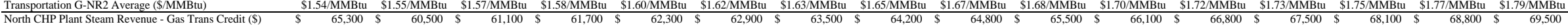

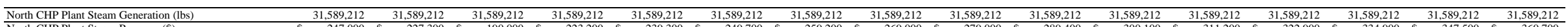

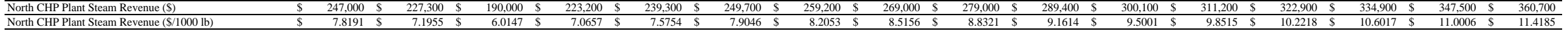

\section{South CHP Plant Steam Revenues} Steam Enthalpy (Btu/b)

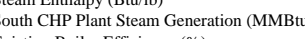
Natural Gas Fuel Units (MMBtu)

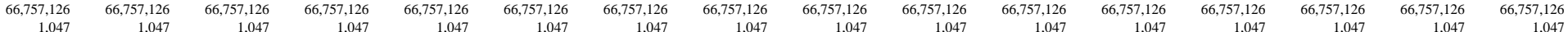
$\frac{\text { Natural Gas Unit Fuel Price City Gate }(S / M M B t u)}{\text { South CHP Plant Steam Revenue - Gas Credit (S) }}$

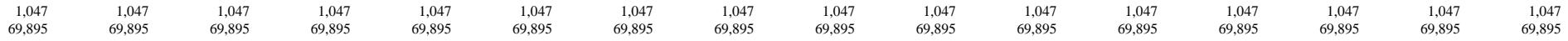

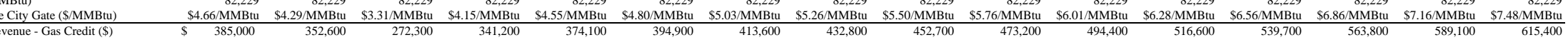

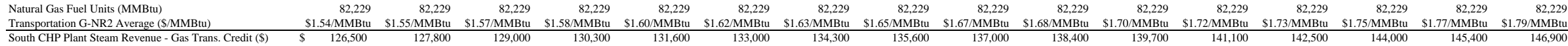

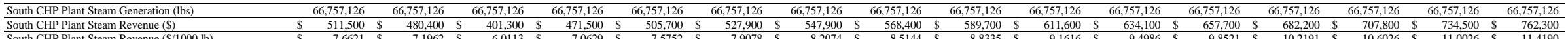

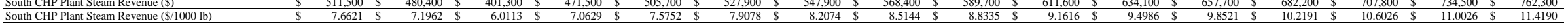

Total CHP Plant Stean Revenues

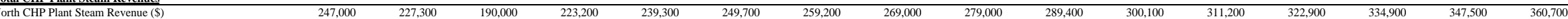

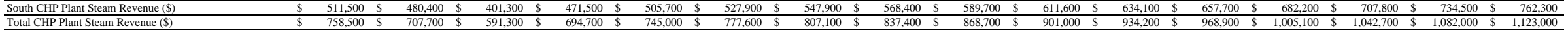


6.0a ANNUAL WASTE DISPOSAL REVENUES

Total CHP Plant Waste Disposal Revenues [1]

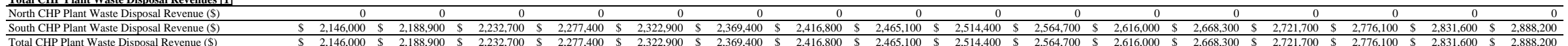

[1] Estimated to be $\$ 2,146,000$ annually, inflatted at $2.0 \%$ per year 


\begin{tabular}{|c|c|c|c|c|c|c|c|c|c|c|c|c|c|}
\hline & $\underline{\text { Jan }}$ & $\underline{\text { Feb }}$ & $\underline{\text { Mar }}$ & Apr & $\underline{\text { May }}$ & $\underline{\text { Jun }}$ & $\underline{\text { Jul }}$ & Aug & $\underline{\text { Sep }}$ & $\underline{\text { Oct }}$ & $\underline{\text { Nov }}$ & $\underline{\text { Dec }}$ & $\underline{2012}$ \\
\hline \multirow{2}{*}{\multicolumn{14}{|c|}{$\begin{array}{l}\text { Electric Generation Capacity } \\
\text { North CHP Plant Generation Capacity }(\mathrm{kW})\end{array}$}} \\
\hline & $\begin{array}{r}0 \\
4,379\end{array}$ & $\begin{array}{r}0 \\
4,379\end{array}$ & $\begin{array}{r}0 \\
4,379\end{array}$ & $\begin{array}{r}0 \\
4,379\end{array}$ & $\begin{array}{r}0 \\
4,379\end{array}$ & $\begin{array}{r}0 \\
4,379\end{array}$ & $\begin{array}{r}0 \\
4,379\end{array}$ & $\begin{array}{r}0 \\
4,379\end{array}$ & $\begin{array}{r}0 \\
4,379\end{array}$ & $\begin{array}{r}0 \\
4,379\end{array}$ & $\begin{array}{r}0 \\
4,379\end{array}$ & $\begin{array}{r}0 \\
4,379\end{array}$ & 4,379 \\
\hline $\begin{array}{l}\text { Total Generation Capacity }(\mathrm{kW}) \\
\end{array}$ & 4,379 & 4,379 & 4,379 & 4,379 & 4,379 & 4,379 & 4,379 & 4,379 & 4,379 & 4,379 & 4,379 & 4,379 & 4,379 \\
\hline \multicolumn{14}{|l|}{ Electric Generation Energy } \\
\hline $\begin{array}{l}\text { North CHP Plant Generation ( } \mathrm{kWh} \text { ) } \\
\text { South CHP Plant Generataio (kWh) }\end{array}$ & $\begin{array}{r}0 \\
3,257,976\end{array}$ & $\begin{array}{r}0 \\
2,211,395\end{array}$ & $\begin{array}{r}0 \\
3,257,976\end{array}$ & $\begin{array}{r}0 \\
3,152,880\end{array}$ & $\begin{array}{r}0 \\
3,257,976\end{array}$ & $\begin{array}{r}0 \\
3,148,501\end{array}$ & $\begin{array}{r}0 \\
2,526,683\end{array}$ & $\begin{array}{r}0 \\
3,257,976\end{array}$ & $\begin{array}{r}0 \\
3,152,880\end{array}$ & $\begin{array}{r}0 \\
3,257,976\end{array}$ & $\begin{array}{r}0 \\
3,152,880\end{array}$ & $3,257,976$ & $\begin{array}{r}0 \\
36,893,075\end{array}$ \\
\hline Total CHP Plant Generation (kWh) & $3,257,976$ & $2,211,395$ & $3,257,976$ & $3,152,880$ & $3,257,976$ & $3,148,501$ & $2,526,683$ & $3,257,976$ & $3,152,880$ & $3,257,976$ & $3,152,880$ & $3,257,976$ & $36,893,075$ \\
\hline \multicolumn{14}{|l|}{ North CHP Plant Production Costs } \\
\hline North CHP Plant Generation Capacity $(\mathrm{kW})$ & 0 & 0 & 0 & 0 & 0 & 0 & 0 & 0 & 0 & 0 & 0 & & \\
\hline North CHP Plant Generation $(\mathrm{kWh})$ & 0 & 0 & 0 & 0 & 0 & 0 & 0 & 0 & 0 & 0 & 0 & & \\
\hline North CHP Plant Heat Rate HHV (Btu/kWh) & 0 & 0 & 0 & 0 & 0 & 0 & 0 & 0 & 0 & 0 & & & \\
\hline \multicolumn{14}{|l|}{$\begin{array}{l}\text { North CHP Plant Fuel Ise HHV VMMBtul) } \\
\text { Natural Gas Unit Fuel Price City Gate (S/MMBtu) }\end{array}$} \\
\hline 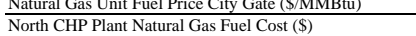 & $\overline{\$}$ & & & & & & & & & & & & \\
\hline \multicolumn{14}{|l|}{$\begin{array}{l}\text { North CHP Plant Fuel Use HHV (MMBtu) } \\
\text { Transportation G-EG (SMMBtu) }\end{array}$} \\
\hline \multicolumn{14}{|l|}{$\begin{array}{l}\text { Transportation G-EG (\$MMMBtu) } \\
\text { North CPP Plant Natural Gas Transportation Cost (\$) }\end{array}$} \\
\hline \multirow{4}{*}{\multicolumn{14}{|c|}{$\begin{array}{l}\text { Total North CHP Plant Natural Gas Use (MMBtu) } \\
\text { Total North CHP Plant Natural Gas Fuel Cost (\$) } \\
\text { Total North CHP Plant Natural Gas Fuel Cost (S/MMBtu) }\end{array}$}} \\
\hline & & & & & & & & & & & & & \\
\hline & & & & & & & & & & & & & \\
\hline & & & & & & & & & & & & & \\
\hline outh & \multicolumn{13}{|c|}{ South CHP P } \\
\hline South CHP Plant Generation (kWh) & $3,257,976$ & $2,211,395$ & $3,257,976$ & $3,152,880$ & $3,257,976$ & $3,148,501$ & $2,526,683$ & $3,257,976$ & $3,152,880$ & $3,257,976$ & $3,152,880$ & $3,257,976$ & $36,893,075$ \\
\hline South CHP Plant Heat Rat & 10,073 & 10,073 & 10,073 & 10,073 & 10,073 & 10,073 & 10,073 & 10,073 & 10,073 & 10,073 & 10,073 & 10,073 & 10,073 \\
\hline GROss south CHP Plant Fuel & 32,818 & 22,276 & 32,818 & 31,759 & 32,818 & 31,715 & 25,451 & 32,818 & 31,759 & 32,818 & 31,759 & 32,818 & 371,627 \\
\hline Maxim! & $\underline{12,648}$ & $\underline{11,424}$ & $\underline{12,648}$ & 12,240 & $\underline{12,648}$ & $\underline{12,240}$ & $\underline{12,648}$ & $\underline{12,648}$ & $\underline{12,240}$ & $\underline{12,648}$ & $\underline{12,240}$ & 12,648 & $\underline{148,920}$ \\
\hline NET South CHP Plant Fuel Use HHV (MMBtu) & 20,170 & 10,852 & 20,170 & 19,519 & 20,170 & 19,475 & 12,803 & 20,170 & 19,519 & 20,170 & 19,519 & 20,170 & 222,707 \\
\hline 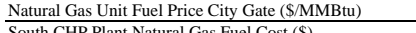 & \$6.37/MMBtu & 3/MMBtu & $\$ 5.15 / \mathrm{MMBtu}$ & 3/MMBtu & 2/MMBtu & 9 MMBtu & SMMBtu & 4/MMBtu & MMBBtu & MMBtu & IMMBtu & & $\$ 4.63 / \mathrm{MMBtu}$ \\
\hline South CHP Plant Natural Gas Fuel Cost (\$) & 128,500 & $62,200 \$$ & $103,900 \$$ & $87,100 \$$ & $91,200 \$$ & $83,500 \mathrm{~s}$ & $59,700 \mathrm{~s}$ & $89,600 \$$ & $70,900 \$$ & $82,500 \mathrm{~s}$ & $77,300 \$$ & & $1,030,200$ \\
\hline $\begin{array}{l}\text { South CHP Plant Fuel Use HHV (MMBtu) } \\
\text { Transportation G-EG (S/MMBtu) }\end{array}$ & $\begin{array}{r}20,170 \\
\text { \$0.31/MMBtu }\end{array}$ & $\begin{array}{r}10,852 \\
\$ 0.31 / \mathrm{MMBtu}\end{array}$ & $\begin{array}{r}20,170 \\
\$ 0.31 / \mathrm{MMBtu}\end{array}$ & $\begin{array}{r}19,519 \\
\text { S0.31/MMBtu }\end{array}$ & $\begin{array}{r}20,170 \\
\$ 0.31 / \mathrm{MMB} \text { Mu }\end{array}$ & $\begin{array}{r}19,475 \\
\$ 0.31 / \text { MMBtu }\end{array}$ & $\begin{array}{r}12,803 \\
\text { \$0.31/MMBtu }\end{array}$ & $\begin{array}{r}20,170 \\
\$ 0.31 / \mathrm{MMBtu}\end{array}$ & $\begin{array}{r}19,519 \\
\$ 0.31 / \text { MMBtu }\end{array}$ & $\begin{array}{r}20,170 \\
0.31 / \text { MMBtu }\end{array}$ & $\begin{array}{r}19,519 \\
\text { 50.31/MMBtu }\end{array}$ & $\begin{array}{r}20,170 \\
0.31 \text { MMBtu }\end{array}$ & $\begin{array}{r}222,707 \\
\$ 0.31 / \mathrm{MMBtu}\end{array}$ \\
\hline South CHP Plant Natural Gas Transportation Cost (\$) & 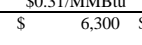 & 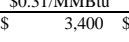 & $\begin{array}{lll}\$ \$ .31 / \mathrm{MMbtu} & \\
\$ & 6,300 & \$\end{array}$ & 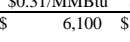 & 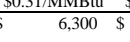 & $\frac{6,800}{\$}$ & 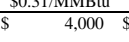 & 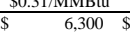 & $\begin{array}{ll}\$ 0.31 / \mathrm{MMBtu} \\
\$ \quad 6,100 \$\end{array}$ & $\begin{array}{l}\$ 0.31 / \mathrm{MMBtu} \\
\$ \quad 6,300 \quad \$\end{array}$ & $\begin{array}{l}\$ 0.31 / \mathrm{MMBtu} \\
\$ \quad 6,100 \quad \$\end{array}$ & $\begin{array}{l}\$ 0.31 / \mathrm{MMBBt} \\
\$ \quad 6,300\end{array}$ & 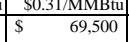 \\
\hline Total South CHP Plant Natura & 20,170 & 10,852 & 20,170 & 19,519 & 20,170 & 19,475 & 12,803 & 20,170 & 19,519 & 20,170 & 19,519 & 20,170 & 222, \\
\hline otal Sol & 134,800 & $65,600 \$$ & $110,200 \quad \$$ & $93,200 \mathrm{~s}$ & $97,500 \$$ & $89,500 \mathrm{~s}$ & $63,700 \mathrm{~s}$ & $95,900 \$$ & 77,000 & $88,800 \mathrm{~s}$ & $83,400 \$$ & t & 999,7 \\
\hline South CHP Plant Natura & Btu & MMBtu & MBtu & MMBtu & MMBtu & 60/MMBtu & IMBtu & 75/MMBtu & 94/MMBtu & MMBtu & /MMBtu & & \$4.94/MMI \\
\hline \multirow{2}{*}{\multicolumn{14}{|c|}{$\frac{\text { Total C }}{\text { Total } N_{c}}$}} \\
\hline 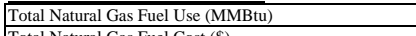 & & & & & & & & & & & & & \\
\hline Total Natural Gas Fuel C & $\$ \quad 134,800$ & $65,600 \$$ & $110,200 \$$ & $93,200 \mathrm{~S}$ & $97,500 \$$ & $89,500 \mathrm{~s}$ & $63,700 \mathrm{~s}$ & $95,900 \$$ & $\begin{array}{ll}77,000 \$ \\
\end{array}$ & $88,800 \$$ & $83,400 \$$ & $\begin{array}{l}0,100 \\
\end{array}$ & 099,70 \\
\hline
\end{tabular}




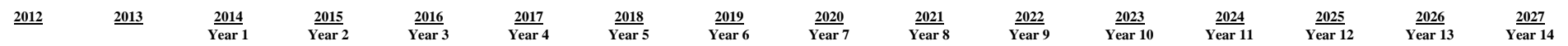

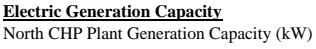

$\frac{\text { South CHP Plant Generation Capacity }(\mathrm{kW})}{\text { Total Generation Capacity }(\mathrm{kW})}$

00

Electric Generation Energy

Nouth CHP Plant Generation $(\mathrm{kWh})$
South $\begin{array}{ll}4,379 & 4,379 \\ 4,379 & 4,379\end{array}$

$\begin{array}{rrr}0 & 0 & 0 \\ 4,379 & 4,379 & 4,379 \\ 4,379 & 4,379 & 4,379\end{array}$
0
4,379
4,379 0
4,379
4,379

$\begin{array}{r}0 \\ 4,379 \\ \hline 4,379\end{array}$
0
4,379
4,379 0
4,379
4,379 0
4,379
4,379 0
4,379
4,379 0
4,379
4,379 \begin{tabular}{rrr}
0 & 0 & 0 \\
4,379 & 4,379 & 4,379 \\
\hline 4,379 & 4,379 & 4,379
\end{tabular}

North CHP Plant Production Costs

North CHP Plant Generation Capacity $(\mathrm{kW})$

North CHP Plant Generation $(\mathrm{kWh})$
North CHP Plant Heat Rate HHV (Buth

North CHP Plant Fuel Use HHV (MMBtu)

$\frac{\text { Natural Gas Unit Fuel Price City Gate (S/MMBtu }}{\text { North CHP Plant Natural Gas Fuel Cost (S) }}$

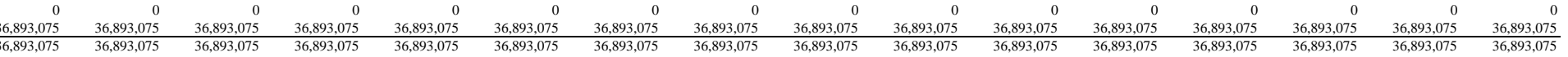

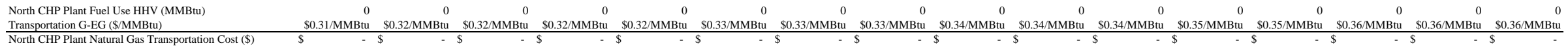

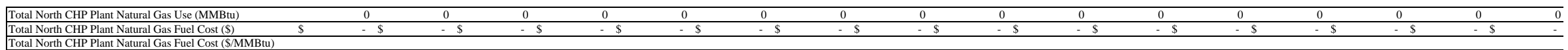

South CHP Plant Production Costs

apacity $(\mathrm{kW})$ South CHP Plant Generation $(\mathrm{kWh})$ (Buth

South CHP Plant Fuel Use HHV (MMBtu) Natural Gas Unit Fuel Price City Gate (\$MMBBtu)

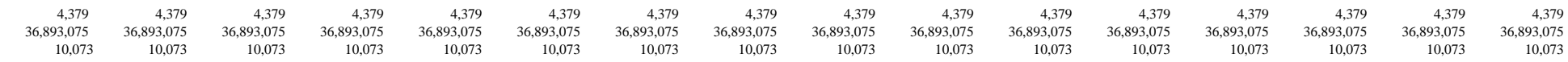
South CHP Plant Fuel Use HHV (MMBtw)

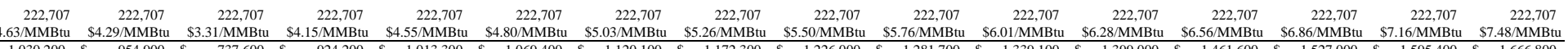
Transportation G-EG (S/MMBtu)

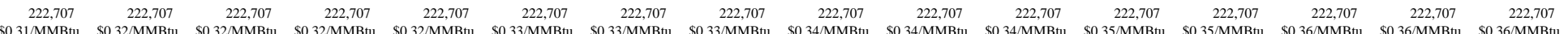
Total South CHP Plant Natural Gas Use (MMBtu)

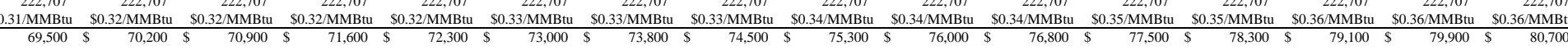
Total South CHP Plant Natural Gas Use (MMBtu)

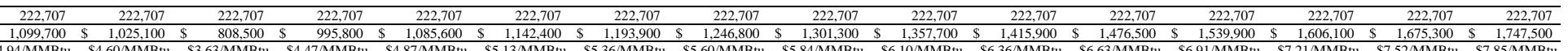

\section{Total CHP Plant Production Costs}

Total Natural Gas Fuel Use (MMBting

\begin{tabular}{l}
\hline Total Natural Gas Fuel Cost (\$) \\
\hline Total Natural Gas Fuel Cost (\$MMBtu) \\
\hline
\end{tabular}

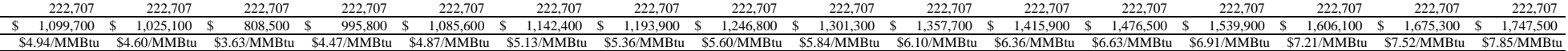
(a) 


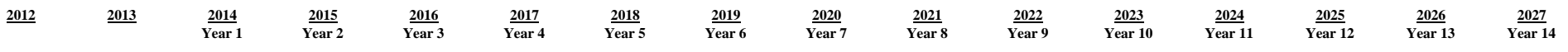
Incremental Labor Costs

\section{Management (Qty)}

Burdened Hourly Rate (Shr)

Escalation (\%)

$\begin{array}{lll}0 & 0 & \\ 0 & 0 & \end{array}$

Additional Operators (Qty)
Burdened Hourly Rate (\$hr)

Burdened Hourly Rate (\$hr)
Escalation (\%)
Operator Labor Cost (\$)

\begin{tabular}{|c|c|c|}
\hline $\begin{array}{c}0 \\
100.00 \\
2.00 \%\end{array}$ & $\begin{array}{c}0 \\
102.00 \\
2.00 \%\end{array}$ & $\begin{array}{c}0 \\
104.04 \\
2.00 \%\end{array}$ \\
\hline
\end{tabular}

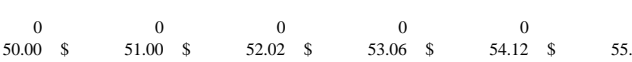

Additional Maintenance Techs (Q

\begin{tabular}{l} 
Burdened Hourly Rate (\$hr) \\
Escalation $\%$ ) \\
\hline Maintenance Techs Labor Cost (\$)
\end{tabular}

\begin{tabular}{l}
$-\$ .00 \%$ \\
\hline
\end{tabular}

Total Additional Labor Cost (\$)

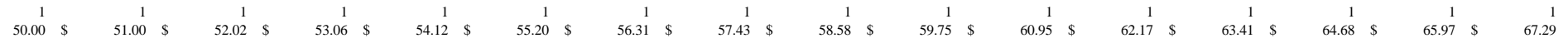

North Plant CHP Maintenance Cos

Number of Units
Prime Mover Maintenance Cost $(\$ /$ unit $)$

$\frac{\text { Escalation (\%) }}{\text { Total Prime Mover Maintenance Cost (\$) }}$

\section{South Plant CHP Maintenance Cost}

South Plant CHPMaintenance Cost
Number of Units
Prime Mover Maintenance Cost $(\$ /$ unit)

Escalation (\%)

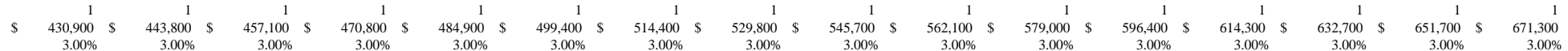
Total Additional Maintenance Cost (\$)

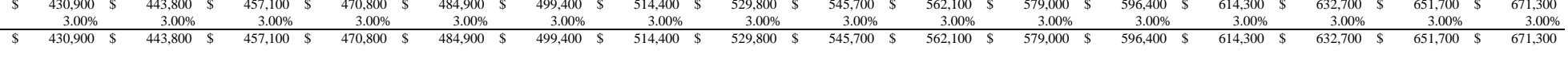

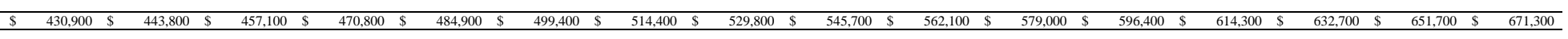




\section{$\frac{\text { Financing Assumption }}{\text { Debt Term (years) }}$} Interest Rate

Interest Rate
Investment Tax Credit
Capital Cost Capital Cost
Less SGIP Incentive

Less SGIP Incentive
Less Tax Credit

Financed Amount

Debt Financed

Equity Financed
Total Debt Financing

Long Term Financing

Interest Rate
Amount to Finan

Beginning Year Balance

Interest
Principal

Principal

End of Year Balance

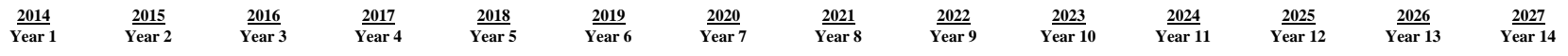
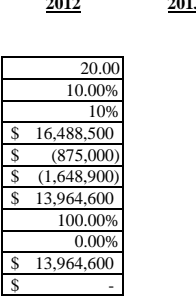

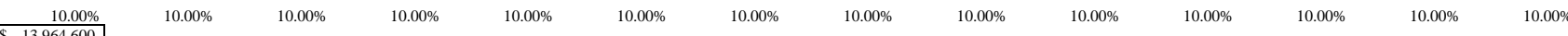

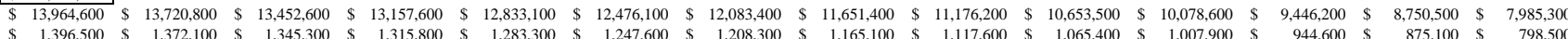

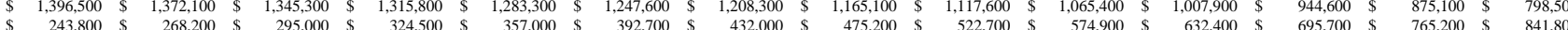

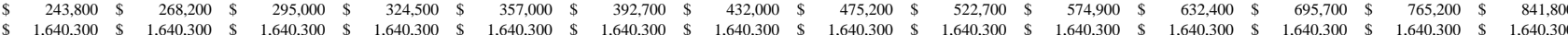

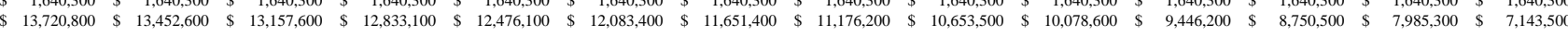


10.0 DEPRECIATION

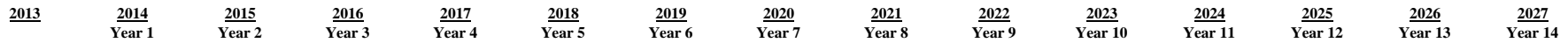

Capital Cost

Less SGIP Incentive
Less Tax Credit

Depreciable Basis

(a)

Year3

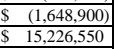

MACRS 5-Year

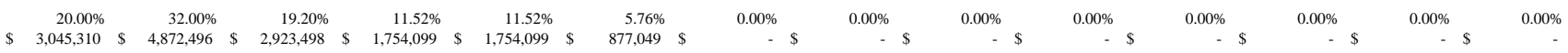
Depreciation Percentage
Depreciation Expense

[1] Depreciable Basis is equal to total project cost less the tax credits and rebate for which the project qualifies. 


\subsection{PRO FORMA}

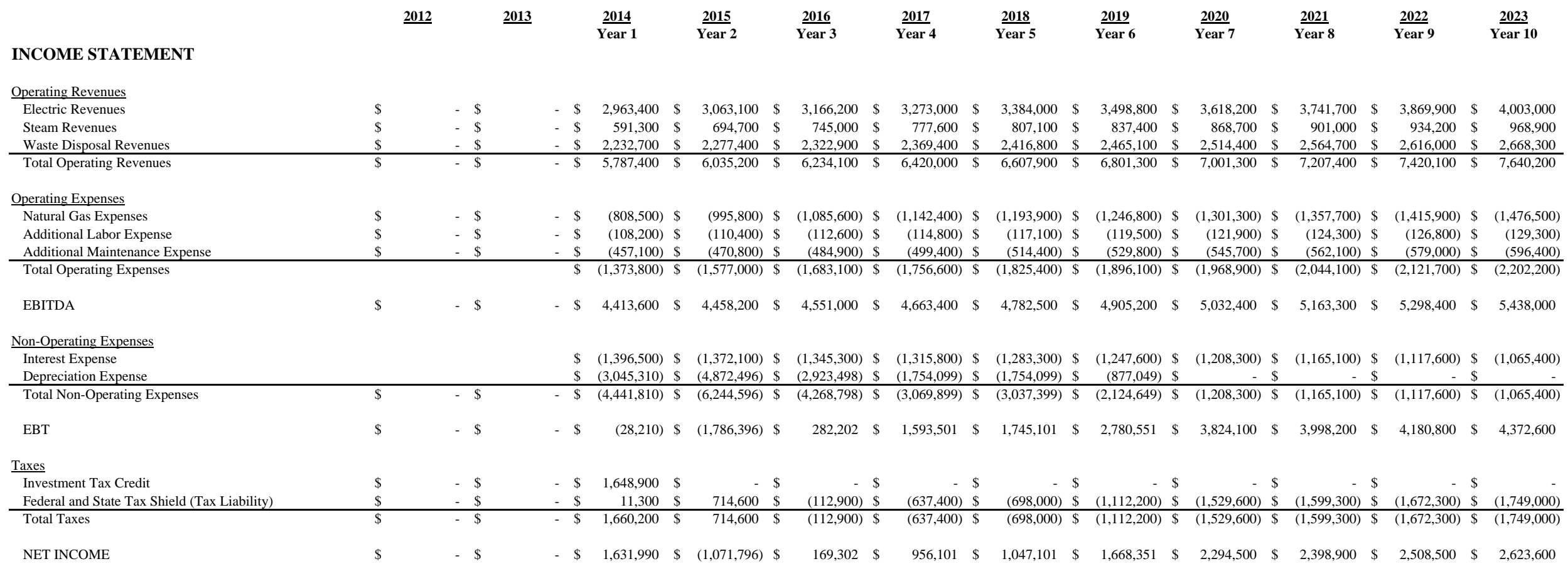

\section{CASH FLOW STATEMENT}

Cash Flows Operating Activities

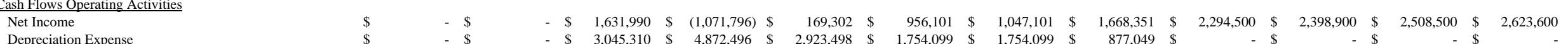

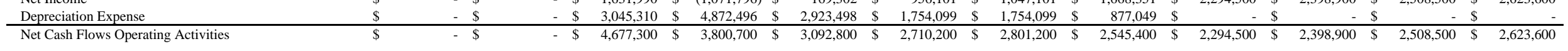

Cash Flows Capital Financing and Investing Activities

\begin{tabular}{lcc} 
Cash Flows Capital Financing and Investing Activities & \\
\hline Proceeds From SGIP Rebate & $\$ 875,000$ \\
Proceeds From Debt & $\$ 13,964,600$ \\
Capital Acquisition Payments & $\$(16,488,500)$
\end{tabular}

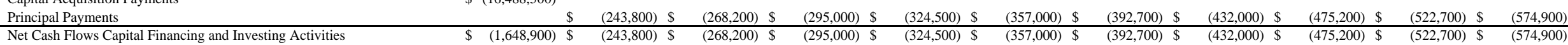

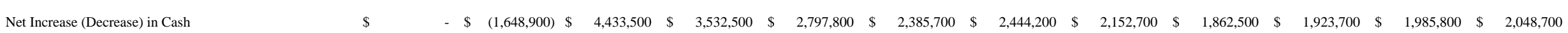

Cumulative Positive Cash Flows

Net Present Value

$\$ 15,511,500$

Discount Rate 
OPTION 2 - SINGLE CHP PLANT WITH MICROTURBINES 


\begin{tabular}{|c|c|c|c|}
\hline & \multirow{2}{*}{\multicolumn{3}{|c|}{ SELECT CONFIGURATION }} \\
\hline $\begin{array}{c}\text { Configuration } \\
\end{array}$ & & & \\
\hline Project Description & \multicolumn{3}{|c|}{$\begin{array}{c}\text { Single CHP Plant Located at South Site - No Steam } \\
\text { Intercomection }\end{array}$} \\
\hline Site & North Site & South Site & Total \\
\hline Estimated Average Electrical Load $(\mathrm{kW})$ & 0 & 1,500 & 1,500 \\
\hline Maximum CHP Electric Generation $(k W)$ & 0 & 5,000 & 5,000 \\
\hline Minimum Steam Load (bb/hr) & $\underline{0}$ & 7,000 & 7,000 \\
\hline Average Steam Load (lb/hr) & 0 & 15,000 & 15,000 \\
\hline Max Steam Load (lbhr) & 0 & 25,000 & 25,000 \\
\hline Power Generation Technology & 0 & Microturbine & Microturbine \\
\hline Manufacturer & 0 & Capstone & Capstone \\
\hline Prime Mover & 0 & $\mathrm{C} 200 \times 9$ & $\mathrm{C} 200 \times 9$ \\
\hline Number of Units & $\mathbf{0}$ & 1 & 1 \\
\hline Gross Power Generation per Unit $(\mathrm{kW})$ & 0 & 1,800 & 1,800 \\
\hline Aux Load per Unit $(k W)$ & 0 & -36 & -36 \\
\hline Net Power Generation per Unit $(k W)$ & 0 & 1,764 & 1,764 \\
\hline Total Power Generation $(\mathrm{kW})$ & 0 & 1,764 & 1,764 \\
\hline Fuel Input per Unit LHV (MMBtu/hr) & 0.00 & 17.00 & 17.00 \\
\hline Fuel Input per Unit HHV (MMBtu/hr) & 0.00 & 18.70 & 18.70 \\
\hline Prime Mover Heat Rate LHV (Bu/kWh) & 0 & 9,637 & 9,637 \\
\hline Prime Mover Heat Rate HHV (BuukWh) & 0 & 10,601 & 10,601 \\
\hline Total Prime Mover Fuel Input LHV (MMBtuhr) & 0.0 & 17.0 & 17.0 \\
\hline Total Prime Mover Fuel Input HHV (MMBtu/hr) & 0.0 & 18.7 & 18.7 \\
\hline Federal Investment Tax Credit (\%) & $0 \%$ & $10 \%$ & $10 \%$ \\
\hline Steam Generation Technology & 0 & HRSG & HRSG \\
\hline Number of Units & 0 & 1 & 1 \\
\hline Steam Generation per Unit (lb/hr) & 0 & 6,300 & 6,300 \\
\hline Total Steam Generation (lb/hr) & 0 & 6,300 & 6,300 \\
\hline Total Project Capital Cost (\$) & $\$$ & S $\quad 11,972,800$ & \$ $\quad 11,972,800$ \\
\hline SGIP Incentive (\$) & $\$$ & $\$ \quad(691,000)$ & s $\quad(691,000)$ \\
\hline Investment Tax Credit (\$) & $\$$ & $\$ \quad(1,197,300)$ & s $\quad(1,197,300)$ \\
\hline Net Project Capital Cost (\$) & s & S $\quad 10,084,500$ & S $\quad 10,084,500$ \\
\hline Prime Mover Maintenance Cost (S/unit) & s & 301,500 & 301,500 \\
\hline Number of Units & 0 & 1 & 1 \\
\hline Total Prime Mover Maintenance Cost (\$) & $\$$ & 301,500 & 301,500 \\
\hline Additional Managers & 0 & 0 & 0 \\
\hline Additional Operators & $\mathbf{0}$ & $\mathbf{0}$ & $\mathbf{0}$ \\
\hline Additional Maintenance & $\mathbf{0}$ & 1 & 1 \\
\hline Typical Chemical Waste Volume $(\mathrm{kg} / \mathrm{yr})$ & 0 & $3,572,000$ & $3,572,000$ \\
\hline $\begin{array}{l}\text { Antcipated Chemical } \\
\text { Fule Facility (kg/yr) }\end{array}$ & 0 & 370,628 & 370,628 \\
\hline Fuel Input provided by WTF Vaporizer (N & 0.00 & 17.00 & 17.00 \\
\hline
\end{tabular}
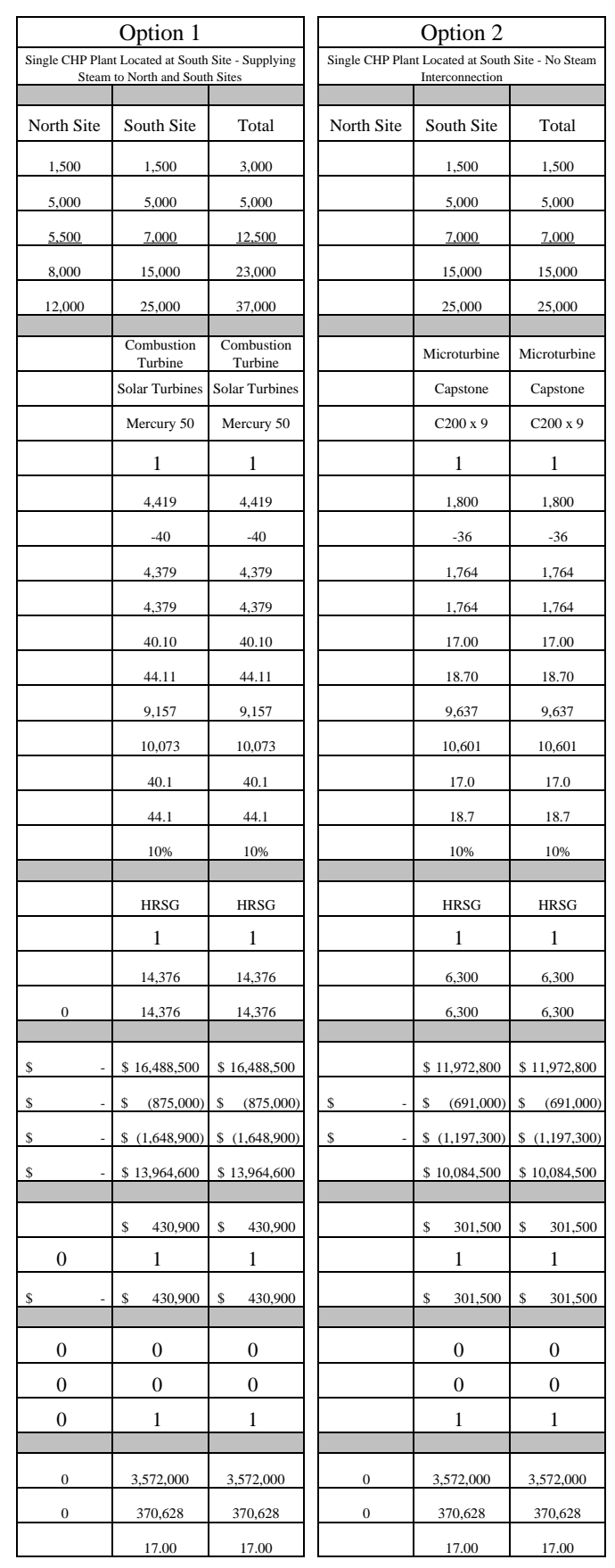

\begin{tabular}{|c|c|c|}
\hline \multicolumn{3}{|c|}{ Option 3} \\
\hline \multicolumn{3}{|c|}{$\begin{array}{l}\begin{array}{l}\text { Single CHP Plant Located a S South Site - No Steam } \\
\text { Interconnection }\end{array} \\
\end{array}$} \\
\hline \multirow{24}{*}{ North Site } & South Site & Total \\
\hline & 1,500 & 1,500 \\
\hline & 5,000 & 5,000 \\
\hline & 7,000 & 7,000 \\
\hline & 15,000 & 15,000 \\
\hline & 25,000 & 25,000 \\
\hline & $\begin{array}{l}\begin{array}{c}\text { Reciprocating } \\
\text { Engine }\end{array}\end{array}$ & $\begin{array}{l}\text { Reciprocating } \\
\text { Ennine }\end{array}$ \\
\hline & GE & GE \\
\hline & $\begin{array}{l}\text { Jenbacher JMS } \\
416\end{array}$ & $\begin{array}{l}\text { Jenbacher JMS } \\
4616\end{array}$ \\
\hline & 2 & 2 \\
\hline & 1,137 & 1,137 \\
\hline & -23 & -23 \\
\hline & 1,114 & 1,114 \\
\hline & 2,229 & 2,229 \\
\hline & 9.78 & 9.78 \\
\hline & 10.75 & 10.75 \\
\hline & 8,774 & 8,774 \\
\hline & 9,651 & 9,651 \\
\hline & 19.6 & 19.6 \\
\hline & 21.5 & 21.5 \\
\hline & $10 \%$ & $10 \%$ \\
\hline & HRSG & HRSG \\
\hline & 2 & 2 \\
\hline & 3,552 & 3,552 \\
\hline 0 & 7,104 & 7,104 \\
\hline & $\$ 10,032,100$ & \begin{tabular}{|l} 
S $10,032,100$ \\
\end{tabular} \\
\hline$\$$ & $\$(529,065)$ & $\$(529,065)$ \\
\hline$\$$ & $\$(1,003,200)$ & $\$(1,003,200)$ \\
\hline$\$$ & \$ $8,499,835$ & S 8,499,835 \\
\hline$\$$ & $\$ \quad 137,100$ & $\begin{array}{ll}\$ & 137,100 \\
\end{array}$ \\
\hline 0 & 2 & 2 \\
\hline$\$$ & $\$ \quad 274,200$ & $\begin{array}{ll}\text { S } & 274,200 \\
\end{array}$ \\
\hline 0 & 0 & 0 \\
\hline 0 & 0 & 0 \\
\hline 0 & 1 & 1 \\
\hline 0 & $3,572,000$ & $3,572,000$ \\
\hline 0 & 370,628 & 370,628 \\
\hline & 17.00 & 17.00 \\
\hline
\end{tabular}




\begin{tabular}{l} 
Gas Price SMMBtu [1] \\
January \\
February \\
March \\
April \\
May \\
June \\
July \\
August \\
September \\
October \\
November \\
December \\
\hline Average
\end{tabular}

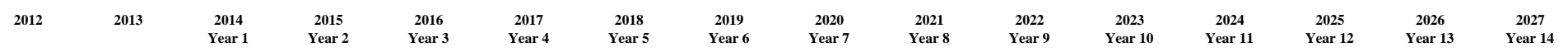

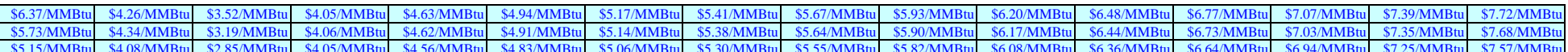

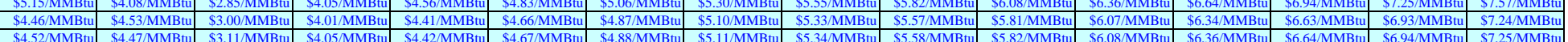

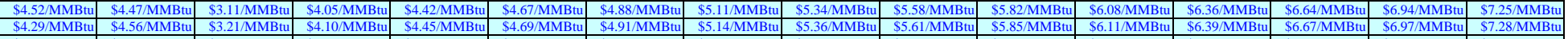

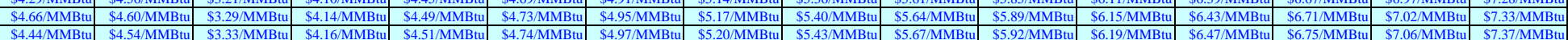

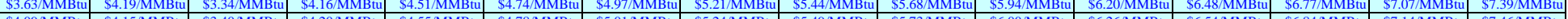

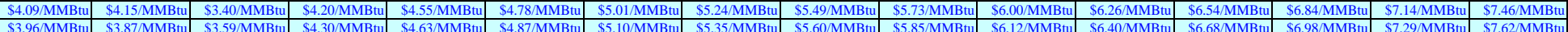

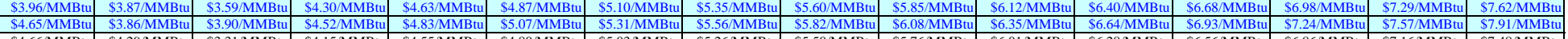

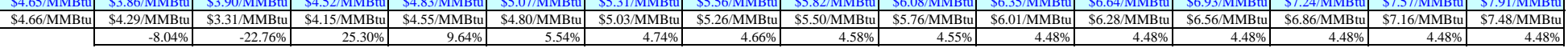

On Peak Energy (\$MWh) [2]

Jebruary

April
May
June

July

August
September

September

November

$\frac{\text { December }}{\text { Average On Peak (\$MWh) }}$

\begin{tabular}{|c|c|c|c|c|c|c|c|c|c|c|c|c|c|c|c|}
\hline $6.91 / \mathrm{MWh}$ & 1 & $\mathrm{Wh}$ & III & (N) & GWh & 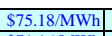 & $.91 / \mathrm{MWh}$ & $39 / \mathrm{MWh}$ & 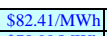 & 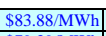 & $\$ 85.68 / \mathrm{MWh}$ & $\$ 86.77 / \mathrm{MWh}$ & \$899.39/MWh & \$91.89/MWh & 994.58 \\
\hline $84 / \mathrm{MWh}$ & $\$ 67.60 / \mathrm{MWh}$ & 4.98/MWh & $\$ 66.25 / \mathrm{MWh}$ & $\$ 69.43 / \mathrm{MWh}$ & $\$ 69.52 \mathrm{MWh}$ & $1.16 / \mathrm{MWh}$ & & $\$ 76.09 / \mathrm{MWh}$ & wn & $\$ 79.39 / \mathrm{MWh}$ & & & $884.61 / \mathrm{MWh}$ & & \\
\hline $4.20 / \mathrm{MV}$ & $\begin{array}{l}865.86 / 1 \\
5077070\end{array}$ & & $\$ 63.78 / \mathrm{MWh}$ & $\$ 66.85 / \mathrm{MWh}$ & $\$ 66.93 / \mathrm{MWh}$ & $\begin{array}{l}868.50 / \mathrm{MWh} \\
8.159\end{array}$ & $\$ 71.91 / \mathrm{MWh}$ & $\begin{array}{l}\$ 73.25 \\
c .20\end{array}$ & MWh & 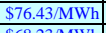 & MWh f & $\overline{\mathrm{Nh}}$ & $1.46 / \mathrm{MWh}$ & $3.73 / \mathrm{MWh}$ & $18 \mathrm{MWh}$ \\
\hline $6.60 / \mathrm{MWh}$ & & $\$ 55.16 /$ & $\$ 56.9$ & & & \$61.15/MWh & $\$ 64.19 / \mathrm{MWh}$ & & & $\$ 68.23 / \mathrm{MWh}$ & & & & & $\overline{\mathrm{nWh}}$ \\
\hline MWh & $\frac{859.19 / \mathrm{MWh}}{\$ 6631 \mathrm{MWh}}$ & $\frac{\$ 54.87 / \mathrm{MWh}}{\$ 55899 \mathrm{MW}}$ & $\frac{856.73 / \mathrm{MWh}}{\$ 66.09 \mathrm{MWh}}$ & $\frac{859.46 / \mathrm{MWh}}{86.91 \mathrm{MWW}}$ & $\frac{\$ 59.54 / \mathrm{MWh}}{\$ 66.00 \mathrm{MWh}}$ & 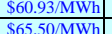 & 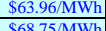 & $\$ 65.16 / \mathrm{MWh}$ & $\$ 66.80 / \mathrm{MWh}$ & $\frac{\$ 67.99 / \mathrm{MWh}}{S 730}$ & 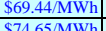 & 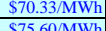 & $\$ 72.46 / \mathrm{MWh}$ & $\$ 874.48 / \mathrm{MWh}$ & $\frac{6.66 / \mathrm{MWh}}{200(5)}$ \\
\hline & & & & & & & & & & & & & & & 40MWh \\
\hline & & & & & & & & & & & & & & & \\
\hline & $\frac{M v}{14}$ & 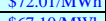 & $\frac{8 t}{S 7}$ & 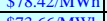 & 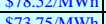 & 5010 & $\frac{38.453 / 1}{9620}$ & 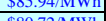 & 380 & 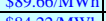 & $\frac{S 91.59}{9032}$ & $\frac{S 9.216}{9071}$ & $x_{2}$ & & \\
\hline 866.8 & & 9641 & & & 570 & & & $38 / M$ & & & & & $\overline{41}$ & $\$ 8844 \sqrt{1}$ & $\frac{1}{4}$ \\
\hline & & & & & & & & & & & & & & & \\
\hline & & & & & & & & & & & & & & & \\
\hline & $\$ 68.25 / \mathrm{N}$ & $\$ 64.29 / \mathrm{MWh}$ & $\$ 66.74 / \mathrm{MWh}$ & $\$ 69.94 / \mathrm{MWh}$ & $\$ 70.04 / \mathrm{MWh}$ & IWh & S75.24/MWh & $\$ 876.65 \mathrm{MWh}$ & $\$ 57.58 \mathrm{MWh}$ & S79.98/MWh & $\$ 81.69 \mathrm{MWh}$ & $\begin{array}{l}\text { S82.74/MWh } \\
\end{array}$ & MWh & $\$ 87.61 \mathrm{MWh}$ & $590.18 \mathrm{MWh}$ \\
\hline
\end{tabular}

Off Peak Energy (S/MWh) [2]

January
February

April
May

June

August
September

October
Novemb

Dovember

December

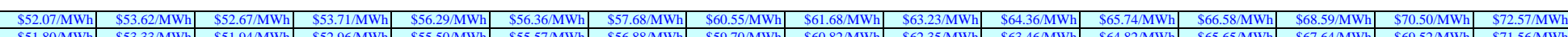

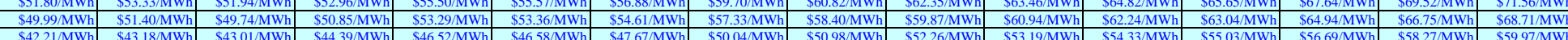

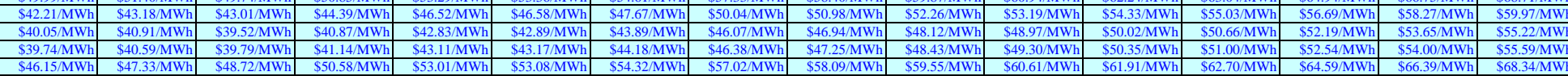

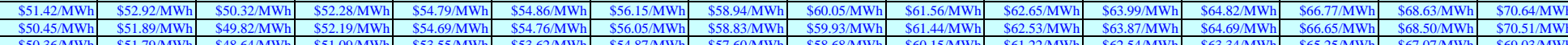

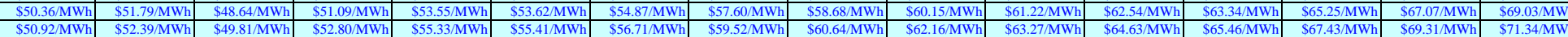

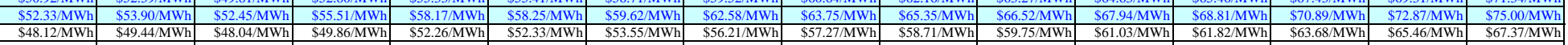

[1] Source: Correlation to Henry Hub futures pricing.
[2] Source: SMUD forecast, prior study. 


\begin{tabular}{|c|c|c|c|c|c|c|c|c|c|c|c|c|c|}
\hline & $\frac{-J a n u a r y}{31}$ & February & $\frac{\text { March }}{31}$ & $\frac{\text { April }}{30}$ & $\frac{\mathrm{Mav}}{31}$ & June & $\frac{\text { July }}{31}$ & $\begin{array}{l}\text { August } \\
11\end{array}$ & $\begin{array}{l}\text { September } \\
\end{array}$ & October & November & December & $\begin{array}{l}\text { Total } \\
365\end{array}$ \\
\hline Energy Consumption (kWh) & $\frac{31}{1,806,040}$ & $\begin{array}{c}28 \\
1,654,580\end{array}$ & $\frac{31}{1,938,140}$ & $\frac{30}{1,874,520}$ & $\frac{31}{2,046,370}$ & $\frac{30}{2,063,900}$ & $\frac{31}{2,224,920}$ & $\frac{31}{2,237,190}$ & $\frac{30}{2,192,432}$ & \begin{tabular}{c|}
31 \\
$2,064,750$
\end{tabular} & $\frac{30}{1,873,760}$ & $\frac{31}{1,772,930}$ & $\begin{array}{c}365 \\
23,749,532\end{array}$ \\
\hline Peak Den & 3,104 & 3,148 & 3,331 & 3,329 & 3,430 & 3,763 & 3,822 & 3,845 & 3,894 & 3,549 & 3,328 & 3,047 & 3,894 \\
\hline Average & 2,427 & 2,462 & 2,605 & 2,604 & 2,750 & 2,867 & 2,990 & 3,007 & 3,045 & 2,775 & 2,602 & 2,383 & 2,710 \\
\hline Min Demand $(\mathrm{kW})$ & 1,751 & 1,776 & 1,879 & 1,878 & 2,071 & 1,970 & 2,159 & 2,169 & 2,196 & 2,002 & 1,877 & 1,719 & 1,719 \\
\hline Load Factor (\%) & $78.20 \%$ & $78.20 \%$ & $78.20 \%$ & $78.20 \%$ & $80.18 \%$ & $76.17 \%$ & $78.25 \%$ & $78.20 \%$ & $78.20 \%$ & $78.20 \%$ & $78.20 \%$ & $78.20 \%$ & $69.63 \%$ \\
\hline Daytim & 3,104 & 3,148 & 3,331 & P & 3,430 & 3,763 & 3,822 & $\begin{array}{r}3,845 \\
3,276\end{array}$ & 3,894 & 3,549 & 3,328 & 3,047 & 3,466 \\
\hline Daytime Energy ( $\mathrm{kWh}$ ) & 1,154,715 & 1,057,877 & 1,239,175 & 1,1988,499 & 1,276,086 & 1,354,729 & 1,421,617 & $1,430,376$ & 1,401, & 1,320,125 & 1,198,013 & $1,133,546$ & ,186,516 \\
\hline $\mid \begin{array}{l}\text { Nighttime Load }(\mathrm{kW}) \\
\text { Nighttime Energy }(\mathrm{kWh})\end{array}$ & $\begin{array}{r}1,751 \\
651,325\end{array}$ & $\begin{array}{c}1,776 \\
596,703\end{array}$ & $\begin{array}{r}1,879 \\
698,965\end{array}$ & $\begin{array}{r}1,878 \\
676,021\end{array}$ & $\begin{array}{r}2,071 \\
770,284\end{array}$ & $\begin{array}{r}1,970 \\
709,171\end{array}$ & $\begin{array}{r}2,159 \\
803,303\end{array}$ & $\begin{array}{r}2,169 \\
806,814\end{array}$ & $\begin{array}{r}2,196 \\
790,672\end{array}$ & $\begin{array}{r}2,002 \\
744,625\end{array}$ & $\begin{array}{r}1,877 \\
675,747\end{array}$ & $\begin{array}{r}1,719 \\
639,384\end{array}$ & $\begin{array}{r}1,954 \\
3,563,016\end{array}$ \\
\hline Total Energy (kWh) & $1,806,040$ & $1,654,580$ & $1,938,140$ & $1,874,520$ & $2,046,370$ & $2,063,900$ & $2,224,920$ & $2,237,190$ & 2,192,432 & $2,064,750$ & $1,873,760$ & $1,772,930$ & $23,749,5$ \\
\hline
\end{tabular}

\begin{tabular}{|c|c|c|c|c|c|c|c|c|c|c|c|c|c|}
\hline STEAM LOAD SUMMARY & January & February & $\underline{\text { March }}$ & April & $\underline{\underline{\text { May }}}$ & $\underline{\text { June }}$ & July & August & September & October & November & December & $\underline{\text { Total }}$ \\
\hline North Site & & & & & & & & & & & & & \\
\hline $\begin{array}{l}\text { North Natural Gas (Therms) } \\
\text { North Natural Gas (MMBtut) }\end{array}$ & $\begin{aligned} 38,086 \\
3,809\end{aligned}$ & $\begin{array}{r}36,124 \\
3,612\end{array}$ & $\begin{array}{r}37,454 \\
3,745\end{array}$ & $\begin{array}{r}34,796 \\
3,480\end{array}$ & $\begin{array}{l}34,866 \\
3487\end{array}$ & $\begin{array}{l}30,282 \\
3028\end{array}$ & $\begin{array}{l}30,596 \\
3360\end{array}$ & $\begin{array}{l}30,095 \\
3010\end{array}$ & $\begin{array}{l}28,610 \\
281\end{array}$ & 33,131 & $\begin{array}{l}36,661 \\
366\end{array}$ & 38,086 & 408,787 \\
\hline 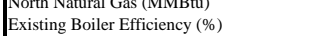 & $\frac{3,809}{85 \%} \mid$ & $\frac{3,612}{85 \%}$ & $\begin{array}{l}3,45 \\
85 \%\end{array}$ & $\begin{array}{l}3,480 \\
85 \%\end{array}$ & $\frac{3,487}{85 \%} \mid$ & $\frac{3,02 \%}{85 \%}$ & $\frac{3,000}{85 \%}$ & $\frac{3,010}{85 \%}$ & $\mid \frac{2,001}{85 \%}$ & $\frac{3,313}{85 \%} \mid$ & $\frac{3,000}{85 \%} \mid$ & (3,009 & $85 \%$ \\
\hline Steam Production (MMBtu) & 3,237 & 3,071 & 3,184 & 2,958 & 2,964 & 2,574 & 2,601 & 2,558 & 2,432 & 2,816 & 3,116 & 3,237 & 34,747 \\
\hline Steam Enthalpy (Btu/b) & 1,047 & 1,047 & 1,047 & 1,047 & 1,047 & 1,047 & 1,047 & 1,047 & 1,047 & 1,047 & 1,047 & 1,047 & 1,047 \\
\hline Steam Production (bs) & $3,091,979$ & $2,932,695$ & $3,040,711$ & $2,824,898$ & $2,830,573$ & $2,458,400$ & $2,483,948$ & $2,443,275$ & $2,322,668$ & $2,689,702$ & $2,976,266$ & $3,091,979$ & $33,187,093$ \\
\hline$\underline{\text { South } S}$ & & & & & & & & & & & & & \\
\hline South Natural Gas (Therms) & 88,867 & 84,289 & 87,394 & 81,191 & 81,354 & 70,657 & 71,392 & 70,223 & 66,756 & 77,305 & 85,541 & 88,867| & \\
\hline $\begin{array}{l}\text { Extsing Boller EEtfleneycy (\%) } \\
\text { Steam Production (MMBtu) }\end{array}$ & $\frac{85 \% \mid}{7,554}$ & $\frac{85 \% \mid}{7165} \mid$ & $\frac{85 \% \mid}{7428}$ & $\frac{85 \% \mid}{6901}$ & $\frac{85 \% \mid}{6.915}$ & $\frac{85 \% \text { | }}{60006}-2$ & $\frac{85 \% \mid}{6068}$ & $\frac{85 \% \mid}{5.969}$ & $\frac{85 \% \mid}{5674}$ & $\frac{85 \% \mid}{6571} \mid$ & $85 \%$ & 7551 & $85 \%$ \\
\hline Steam Enthalpy (Bt & $\frac{1,554}{1,147}$ & $\begin{array}{l}7,165 \\
1,147\end{array}$ & $\begin{array}{l}7,428 \\
1,147\end{array}$ & 6,901 & 6,915 & 6,006 & 6,068 & 5,969 & 5,674 & 6,571 & $\begin{array}{l}7,271 \\
1,147\end{array}$ & , 1,554 & $\begin{array}{l}81,076 \\
1,147\end{array}$ \\
\hline Steam Production (lbs) & $6,585,618$ & $6,246,359$ & $6,476,422$ & $6,016,762$ & $6,028,849$ & $5,236,156$ & $5,290,572$ & $5,203,942$ & $\begin{array}{l}4,147,059 \\
4,949\end{array}$ & $5,728,807$ & $6,339,162$ & \begin{tabular}{r|r|r|r|}
$6,585,618$ \\
\end{tabular} & $70,685,326$ \\
\hline Total Natural C & 126,953 & \begin{tabular}{|c|}
120,413 \\
\end{tabular} & \begin{tabular}{|l|l|}
124,848 \\
\end{tabular} & 115,987 & 116,220 & 100,939 & 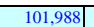 & 100,318 & 95,366 & 110,436 & 122,202 & 126,953 & $1,362,623$ \\
\hline Total Natural C & 12,695 & & 12,485 & 11,599 & 11,622 & 10,094 & 10,199 & 10,032 & 9,537 & 11,044 & 12,220 & 12,695 & 136,262 \\
\hline Total Steam Demand (MMBtu) & 10,791 & 10,235 & 10,612 & 9,859 & 9,879 & 8,580 & 8,669 & 8,527 & 8,106 & 9,387 & 10,387 & 10,791 . & 115,823 \\
\hline Total Steam Demand (lbs) & $9,677,596$ & $9,179,054$ & $9,517,133$ & $8,841,661$ & $8,859,422$ & $7,694,555$ & $7,774,520$ & $7,647,217$ & $7,269,727$ & $8,418,509$ & $9,315,429$ & $9,677,596$ & $103,872,419$ \\
\hline
\end{tabular}

4.1 CHP DISPATCH SUMMARY

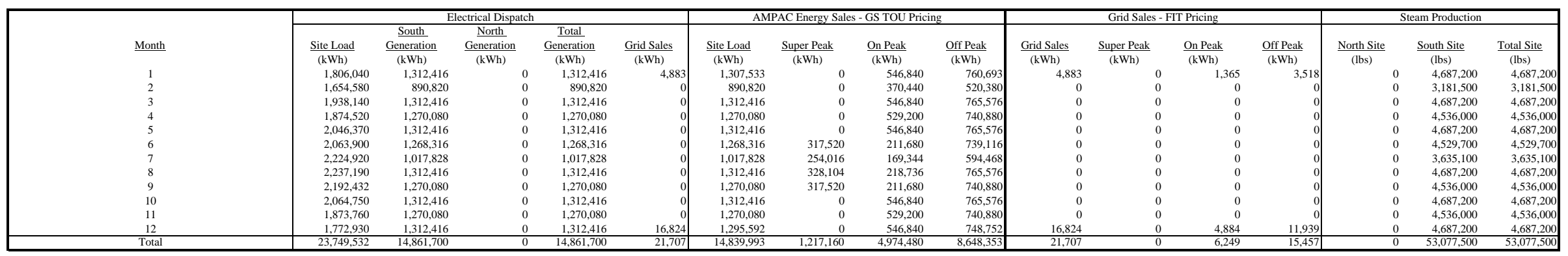




\begin{tabular}{|c|c|c|c|c|c|c|c|c|c|c|c|c|c|c|c|c|c|c|}
\hline & & $\underline{\text { Jan }}$ & $\underline{\text { Feb }}$ & & $\underline{\text { Mar }}$ & & Apr & & $\underline{\text { May }}$ & $\underline{\text { Jun }}$ & $\underline{\text { Jul }}$ & Aug & $\underline{\text { Sep }}$ & $\underline{\text { Oct }}$ & & $\underline{\text { Nov }}$ & $\underline{\text { Dec }}$ & $\underline{2012}$ \\
\hline $\begin{array}{l}\text { Electric Generation Capacity } \\
\text { North CHP Plant Generation Capacity }(\mathrm{kW})\end{array}$ & & & & & & & & & & & & & & 0 & & & & \\
\hline South CHP Plant Generation Capacity (kW) & & 1,764 & 1,764 & & 1,764 & & 1,764 & & 1,764 & 1,764 & 1,764 & 1,764 & 1,764 & 1,764 & & 1,764 & 1,764 & $\begin{array}{r}1,764 \\
\end{array}$ \\
\hline Total Generation Capacity $(\mathrm{kW})$ & & 1,764 & 1,764 & & 1,764 & & 1,764 & & 1,764 & 1,764 & 1,764 & 1,764 & 1,764 & 1,764 & & 1,764 & 1,764 & 1,764 \\
\hline Electric Generation Energy & & & & & & & & & & & & & & & & & & \\
\hline $\begin{array}{l}\text { North CHPP Plant Generation ( } \mathrm{kWh} \text { ) } \\
\text { South CHP Plant Generation }(\mathrm{kWhh}\end{array}$ & & $\begin{array}{r}0 \\
1,312,416\end{array}$ & $\begin{array}{r}0 \\
890,820\end{array}$ & & $\begin{array}{r}0 \\
1,312,416\end{array}$ & & $\begin{array}{r}0 \\
1,270,080\end{array}$ & & $\begin{array}{r}0 \\
1,312,416\end{array}$ & $\begin{array}{r}0 \\
1,268,316\end{array}$ & $\begin{array}{r}0 \\
1.017,828\end{array}$ & $\begin{array}{r}0 \\
1,312,416\end{array}$ & $\begin{array}{r}0 \\
1,270,080\end{array}$ & $\begin{array}{r}0 \\
1,312,416\end{array}$ & & $\begin{array}{r}0 \\
1,270,080\end{array}$ & $\begin{array}{r}0 \\
1,312,416\end{array}$ & $\begin{aligned} 0 \\
14,861,700\end{aligned}$ \\
\hline Total CHP Plant Generation (kWh) & & $1,312,416$ & 890,820 & & $1,312,416$ & & $1,270,080$ & & $1,312,416$ & $\frac{1,268,316}{1,2616}$ & $\frac{1,017,828}{1,028}$ & $1,312,416$ & $1,270,080$ & $1,312,416$ & & $1,270,080$ & $1,312,416$ & $14,861,700$ \\
\hline$\underline{\text { Total Energy Sales }}$ & & & & & & & & & & & & & & & & & & \\
\hline $\begin{array}{l}\text { AMPAC Energy Sales (kWh) } \\
\text { SMUDT Grid Fnergo Sales (kWh }\end{array}$ & & $\begin{array}{r}1,307,533 \\
4883\end{array}$ & 890,820 & & $1,312,416$ & & $1,270,080$ & & $1,312,416$ & $1,268,316$ & $1,017,828$ & $1,312,416$ & $1,270,080$ & $1,312,416$ & & $1,270,080$ & $\begin{array}{r}1,295,592 \\
{ }_{16824}\end{array}$ & $14,839,993$ \\
\hline Total CHP Plant Generation (kWh) & & $1,312,416$ & 890,820 & & $1,312,416$ & & $1,270,080$ & & $1,312,416$ & $1,268,316$ & $1,017,828$ & $1,312,416$ & $1,270,080$ & $1,312,416$ & & $1,270,080$ & $\begin{array}{ll}1,312,416 \\
\end{array}$ & $\begin{array}{r}21,707 \\
14,861,700\end{array}$ \\
\hline MPAC Energy Sales & & & & & & & & & & & & & & & & & & \\
\hline uper Peak Energy Sales ( $\mathrm{kWh}$ ) & & & 0 & & 0 & & 0 & & $0 \square$ & 317,520 & 254,016 & 328,104 & 317,520 & 0 & & 0 & & $1,217,160$ \\
\hline On Peak Energy Sales (kWh) & & 546,840 & 370,440 & & 546,840 & & 529,200 & & 546,840 & 211,680 & 169,344 & 218,736 & 211,680 & 546,840 & & 529,200 & 546,840 & $\begin{array}{r}4,974,480 \\
\end{array}$ \\
\hline$\frac{\text { off Peak Energy Sales }(k W h)}{A M P A C \text { Enery Sales }}$ & & $\begin{array}{r}760,693 \\
1307533 \\
\end{array}$ & $\frac{520,380}{880800}$ & & $\begin{array}{r}765,576 \\
131216\end{array}$ & & $\begin{array}{r}740,880 \\
1.27080\end{array}$ & & $\begin{array}{r}765,576 \\
131216\end{array}$ & $\begin{array}{r}739,116 \\
1,268,316\end{array}$ & $\begin{array}{r}594,468 \\
1,017,828\end{array}$ & $\begin{array}{r}765,576 \\
1,312,416\end{array}$ & $\begin{array}{r}740,880 \\
1,270,080\end{array}$ & $\begin{array}{r}765,576 \\
1,312,416\end{array}$ & & $\begin{array}{r}740,880 \\
1,270,080\end{array}$ & \begin{tabular}{r|}
748,752 \\
$1,295,592$
\end{tabular} & $\begin{array}{r}8,648,353 \\
14,839,993 \\
\end{array}$ \\
\hline & & & & & & & & & & & & & & & & & & \\
\hline $\begin{array}{l}\text { SMUD - GS TOU Rate } \\
\text { Super Peak Energy Rate }(\$ / k W h)\end{array}$ & $\$$ & - & & $\$$ & & $\$$ & & $s$ & 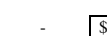 & 0.1203 & $0.1203 \mathrm{~s}$ & 0.1203 & $0.1203 \mathrm{~s}$ & & $\$$ & $\$$ & & 0.1204 \\
\hline On Peak Energy Rate ( $(\mathrm{k}$ Wh) & $\$$ & $0.0883 \mathrm{~s}-\mathrm{s}-\mathrm{l}$ & 0.0883 & $\$$ & 0.0883 & $\$$ & 0.0883 & $\$$ & $0.0883 \$$ & 0.1057 & $0.1057 \$$ & 0.1057 & 0.1057 \$ & 0.0883 & & $0.0883 \$$ & 0.0883 & 0.0911 \\
\hline Off Peak Energy Rate ( $(\mathrm{s} / \mathrm{kWh})$ & $\$$ & $0.0699 \mathrm{~s}$ & 0.0699 & $\$$ & 0.0699 & $\$$ & 0.0699 & \$ & $0.0699 \$$ & 0.0863 & $0.0863 \$$ & 0.0863 & $0.0863 \$$ & 0.0699 & $\$$ & $0.0699 \$$ & 0.0699 & 0.0753 \\
\hline MPA & & & & & & & & & & & & & & & & & & \\
\hline Super $\mathrm{F}$ & $\$$ & & & & & $\$$ & & & $-\$$ & 38,200 & $30,600 \mathrm{~s}$ & 39,500 & $38,200 \$$ & & & $\$$ & & 146,500 \\
\hline On Peak Energy Revenues (\$) & $\$$ & $48,300 \mathrm{~s}$ & 32,700 & & 48,300 & $\$$ & 46,700 & \$ & $48,300 \$$ & 22,400 & & 23,100 & $2,2,400 \$$ & 48,300 & & $46,700 \$$ & 48,300 & 453,400 \\
\hline Off Peak Energy Revenues (\$) & $\$$ & $53,200 \mathrm{~s}$ & 36,400 & $\$$ & 53,500 & $\$$ & 51,800 & s & $53,500 \$$ & 63,800 & $51,300 \mathrm{~s}$ & 66,100 & $63,900 \$$ & 53,500 & & $51,800 \$$ & 52,300 & 651,100 \\
\hline $\begin{array}{l}\text { AMPAC Energy Revenues (\$) } \\
\end{array}$ & $\$$ & $101,500 \$$ & 69,100 & $\$$ & 101,800 & $\$$ & 98,500 & $\$$ & $101,800 \$$ & 124,400 & $99,800 \$$ & 128,700 & $124,500 \$$ & 101,800 & $\$$ & $98,500 \$$ & \begin{tabular}{l|l}
100,600 \\
\end{tabular} & $\$ \quad 1,251,000$ \\
\hline MUDG & & & & & & & & & & & & & & & & & & \\
\hline Super P & & 0 & 0 & & 0 & & 0 & & $0 \square$ & 0 & 0 & 0 & 0 & 0 & & 0 & & \\
\hline $\begin{array}{l}\text { On Peak Energy Sales }(\mathrm{kWh}) \\
\text { OffP Peak Enory S Slas }(\mathrm{kWhb})\end{array}$ & & 1,365 & 0 & & 0 & & 0 & & 0 & 0 & 0 & 0 & 0 & 0 & & 0 & $\begin{array}{r}4,884 \\
11939\end{array}$ & $\begin{array}{r}6,249 \\
15457\end{array}$ \\
\hline $\begin{array}{l}\text { Off Peak Energy Sales }(\mathrm{kWh}) \\
\text { SMUD Grid Energy Sales (kWh) }\end{array}$ & & $\frac{3,518}{4,883}$ & $\frac{0}{0}$ & & $\frac{0}{0}$ & & $\frac{0}{0}$ & & $\frac{0}{0}$ & $\frac{0}{0}$ & $\frac{0}{0}$ & $\frac{0}{0}$ & $\frac{0}{0}$ & $\frac{0}{0}$ & & 0 & $\begin{array}{lll}11,939 \\
16824\end{array}$ & $\frac{15,457}{21707}$ \\
\hline 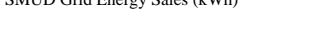 & & 4,003 & 0 & & 0 & & 0 & & 0 & 0 & 0 & 0 & 0 & 0 & & 0 & $10,0<4$ & 21,707 \\
\hline SMUD - FIT Re & & & & & & & & & & & & & & & & & & \\
\hline Super & s & $0.0606 \$$ & 0.0606 & $\$$ & 0.0505 & $\$$ & 0.0505 & s & $0.0505[\$$ & 0.2235 & $0.2235 \$$ & 0.2235 & $0.2235 \$$ & 0.0606 & & $0.0606 \$$ & 0.0606 & $\$$ \\
\hline ( & $\$$ & $0.0551 \mathrm{~s}$ & 0.0551 & $\$$ & 0.0486 & $\$$ & 0.0486 & $\$$ & $0.0486 \$$ & 0.0583 & $0.0583 \$$ & 0.0583 & $0.0583 \$$ & 0.0551 & & 551 \$ & 0.0551 & 0.0640 \\
\hline Off Peak Energy Rate ( $\$(k W h)$ & $\$$ & $0.0433 \mathrm{~s}$ & 0.0433 & $\$$ & 0.0374 & $\$$ & 0.0374 & $\$$ & $0.0374 \$$ & 0.0499 & $0.0499 \$$ & 0.0499 & $0.0499 \$$ & 0.0433 & $\$$ & $0.0433 \$$ & 0.0433 & 0.0453 \\
\hline & & & & & & & & & & & & & & & & & & \\
\hline Sul & $\$$ & $-s$ & & $\$$ & - & $\$$ & - & $\$$ & $-\$$ & - & $-\$$ & & s $\$$ & & $\$$ & $-\$$ & & $\$$ \\
\hline On & $\$$ & $100 \$$ & & $\$$ & - & $\$$ & - & $\$$ & 5 & & & 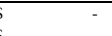 & $\$$ & & $\$$ & $-\$$ & $\begin{array}{r}300 \\
500\end{array}$ & 400 \\
\hline$\frac{\text { Off Peak Energy Revenues }(\$)}{\text { SMEDT }}$ & $\$$ & $200 \mathrm{~s}$ & & $\$$ & - & $\frac{\$}{s}$ & & s & $\$$ & - & $\frac{\$}{s}$ & 5 & $\frac{8}{5}$ & & 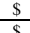 & $\frac{\$}{8}$ & 500 & 700 \\
\hline otal CHP Plant Energy Reven & & & & & & & & & & & & & & & & & & \\
\hline AN & $\$$ & $101,500 \mathrm{~s}$ & 69,100 & $\$$ & 101,800 & $\$$ & 98,500 & $\$$ & $101,800 \$$ & 124,400 & $99,800 \$$ & 128,700 & $124,500 \quad \$$ & 101,800 & S & $98,500 \$$ & 100,600 & 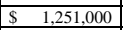 \\
\hline $\begin{array}{l}\text { SMUD Grid Energy Revenues (\$) } \\
\end{array}$ & $\$$ & $300 \$$ & & $\$$ & & $\$$ & & $s$ & 95 & & 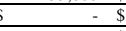 & & $-\$$ & & $s$ & $-\$$ & 800 & $\begin{array}{|lr|}\$ & 1,100 \\
\end{array}$ \\
\hline Total Energy Revenues (\$) & $\$$ & $101,800 \mathrm{~s}$ & 69,100 & $\$$ & 101,800 & s & 98,500 & $\mathrm{~s}$ & $101,800 \quad \mathrm{~s}$ & $124,400=$ & $99,800 \quad \mathrm{~s}$ & 128,700 & $124,500 \mathrm{~s}$ & 101,800 & & $98,500 \$$ & 101,400 & \begin{tabular}{|l|l|l|} 
& $1,252,100$ \\
\end{tabular} \\
\hline
\end{tabular}




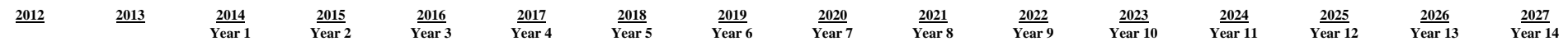

$\frac{\text { Electric Generation Capaciv }}{\text { North CHP Plant Generation Capacity }(k W)}$

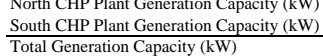
0
1,764
1,764

$\begin{array}{rrr}0 & 0 & 0 \\ 1,764 & 1,764 & 1,764 \\ 1,764 & 1,764 & 1,764\end{array}$

0
1,764
1,764

Electric Generation Energy

$\frac{\text { South } C H P \text { Plant Eeneration }(k W h)}{\text { Total CHP Plant Generation (kWh) }}$

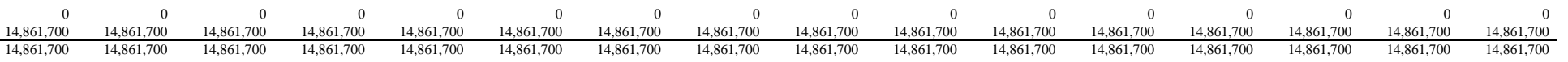

$\frac{\text { Total Energy Sales }}{\text { AMPAC Energy Sales (kWh) }}$

SMUD Grid Energy Sales (kWh)

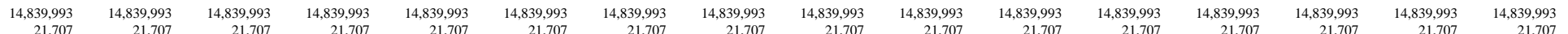
Total CHP Plant Generation (kWh)

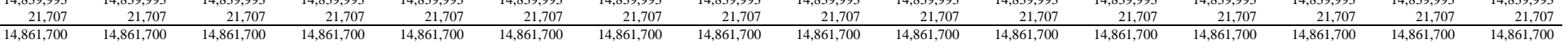

AMPAC Energy Sales

\begin{tabular}{l} 
On Peak Energy Sales $(\mathrm{kWh})$ \\
Off Peak Energy Sales $(\mathrm{kWh})$ \\
\hline AMPAC Enegy Sales $(\mathrm{kWh})$
\end{tabular}

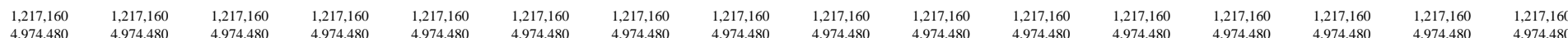

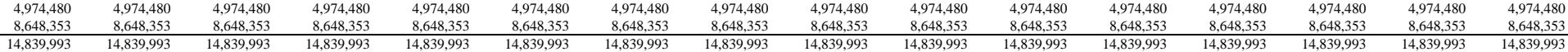

\section{SMUD - GS TOU Rate}

Super Peak Energy Rate $(\$ / k W$ h

Off Peak Energy Rate ( $(\$ / k W h)$

AMPAC Energy Revenues

On Peak Energy Revenues (\$)

Off Peak Energy Revenues (\$)

SMUD Grid Energy Sales

Super Peak Energy Sales ( $(\mathrm{WWh})$
On Peak Energy Sales (kWh)

On Peak Energy Sales $(\mathrm{kWh})$
Off Peak Energy Sales $(\mathrm{kWh})$

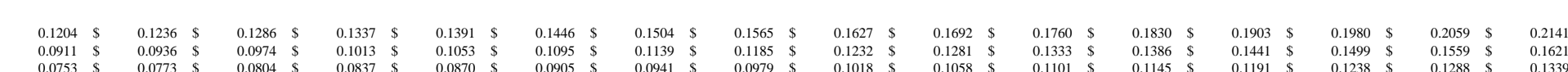

SMUD - FIT Rate

Super Peak Energy Rate ( $\$ / k W h)$

Off Peak Energy Rate ( $($ S k Wh $)$

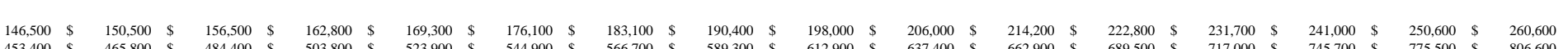

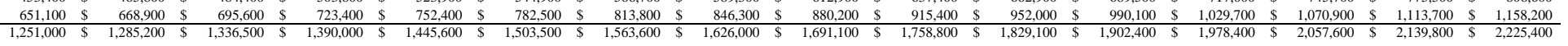

\section{SMUD Grid Energy Revenues}

Super Peak Energy Revenues (\$)
On Peak Energy Revenues (\$)

On Peak Energy Revenues (\$)
Off Peak Energy Revenues $(\$)$

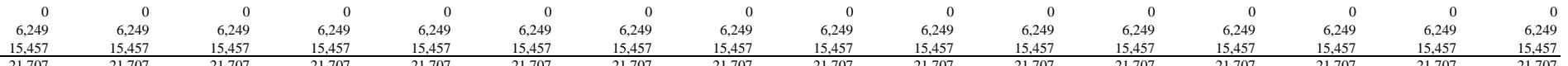

Total CHP Plant Energy Revenues

AMPAC Energy Revenues (\$)

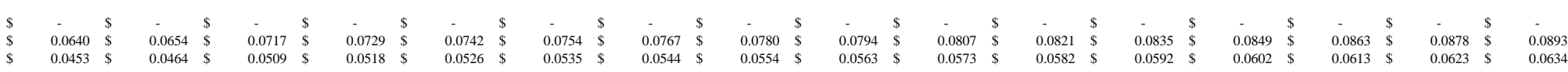

SMOD Grid Energy Revenues

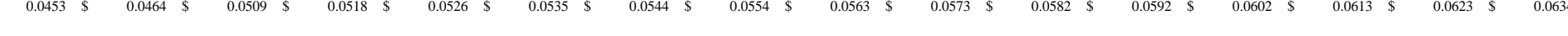




\begin{tabular}{|c|c|c|c|c|c|c|c|c|c|c|c|c|c|}
\hline & $\underline{\text { Jan }}$ & $\underline{\text { Feb }}$ & $\underline{\text { Mar }}$ & Apr & $\underline{\text { May }}$ & $\underline{\text { Jun }}$ & $\underline{\mathrm{Jul}}$ & $\underline{\text { Aug }}$ & $\underline{\text { Sep }}$ & $\underline{\text { Oct }}$ & $\underline{\text { Nov }}$ & $\underline{\text { Dec }}$ & $\underline{2010}$ \\
\hline & & & & & & & & & & & & & \\
\hline $\begin{array}{l}\text { pacaity (bshlr) } \\
\text { pacity (lbshr) }\end{array}$ & 6,300 & 6,300 & 6,300 & 6,300 & 6,300 & 6,300 & 6,300 & 6,300 & $\begin{array}{r}0 \\
6,300 \\
6\end{array}$ & $\begin{array}{r}0 \\
6,300\end{array}$ & $\begin{array}{r}0 \\
6,300\end{array}$ & $\begin{array}{r}0 \\
6,300 \\
\end{array}$ & 6,300 \\
\hline Total Generation Capacity (lbs & 6,300 & 6,300 & 6,300 & 6,300 & 6,300 & 6,300 & 6,300 & 6,300 & 6,300 & 6,300 & & 6,300 & \\
\hline \multicolumn{14}{|l|}{$\operatorname{lam}$} \\
\hline DI & & & & & & & & & & & & & \\
\hline $\begin{array}{l}\text { outh CHP Plant Steam Generation (1) } \\
\text { total CHP Plant Steam Generation (1) }\end{array}$ & $\begin{array}{l}4,687,200 \\
4,687,200\end{array}$ & $\frac{3,181,500}{3,181,500}$ & $\begin{array}{r}4,687,200 \\
4,687,200\end{array}$ & $\begin{array}{r}4,536,000 \\
4,536,000\end{array}$ & $\begin{array}{l}4,687,200 \\
4,687,200\end{array}$ & $\begin{array}{l}4,529,700 \\
4,529,700\end{array}$ & $\begin{array}{l}3,635,100 \\
3,635,100\end{array}$ & $\begin{array}{l}4,687,200 \\
4,687,200\end{array}$ & $\begin{array}{r}4,536,000 \\
4,536,000\end{array}$ & $\begin{array}{l}4,687,200 \\
4,687,200\end{array}$ & $\begin{array}{l}4,536,000 \\
4,536,000\end{array}$ & $\begin{array}{r}4,687,200 \\
4,687,200\end{array}$ & $\begin{aligned} 53,077,500 \\
53,077,500\end{aligned}$ \\
\hline \multirow{2}{*}{\multicolumn{14}{|c|}{ orth CHP Plant Steam $\mathrm{F}$}} \\
\hline & & & & & & & & & & & & & \\
\hline Steam Enthalp & 1,047 & 1,047 & 1,047 & 1,047 & 1,047 & 1,047 & 1,047 & 1,047 & 1,047 & 1,047 & 1,047 & 1,047 & 1,047 \\
\hline neration (I) & 0 & & & 0 & 0 & 0 & 0 & 0 & 0 & 0 & 0 & & \\
\hline xisting & $85 \%$ & $85 \%$ & $85 \%$ & $85 \%$ & $85 \%$ & $85 \%$ & $85 \%$ & $85 \%$ & $85 \%$ & $85 \%$ & $85 \%$ & $85 \%$ & $85 \%$ \\
\hline Natural C & & & & & & & & & & & 0 & & \\
\hline atural & MMBtu & MBtu & IMBtu & IBtu & Btu & & & & & & & & MMI \\
\hline Orth CHP Plant Steam & -5 & & & & & & & & & & & & \\
\hline tural Gas Fuel Un & 0 & 0 & 0 & 0 & 0 & 0 & 0 & 0 & 0 & 0 & 0 & & \\
\hline & .02/MMBtu & 02/MMBtu & $\$ 4.02 / \mathrm{MMBtu}$ & \$3.28/MMBtu & $\$ 3.28 / \mathrm{MMBtu}$ & MBtu & IMBtu & $\$ 3.28 / \mathrm{MMBtu}$ & IMBtu & $\$ 3.28 / \mathrm{MMBtu}$ & IMBtu & & \\
\hline Transportatior & \$1.57/MMBtu & $\$ 1.57 / \mathrm{MMBtu}$ & $\$ 1.57$ MMBtu & \$1.28/MMBtu & $\$ 1.28 / \mathrm{MMBtu}$ & $\$ 1.28 / \mathrm{MMBtu}$ & $\$ 1.28 / \mathrm{MMBtu}$ & $\$ 1.28 / \mathrm{MMBtu}$ & \$1.28/MMBtu & \$1.28/MMBtu & $\$ 1.57 / \mathrm{MMBtu}$ & $\$ 1.57 / \mathrm{MMBtu}$ & \\
\hline 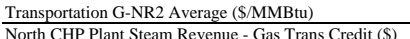 & $\begin{array}{l}\text { \$1.73/MMBtu } \\
\text { S. }\end{array}$ & $\$ 1.81 /$ MMBtu & $\$ 1.73 / \mathrm{MMBtu}$ & $\begin{array}{l}\text { \$1.43/MMBtu } \\
\text { \$ }\end{array}$ & $\$ 1.42 / \mathrm{MMBtu}$ & $\$ 1.43 / \mathrm{MMBtu}$ & $\$ 1.45 / \mathrm{MMBtu}$ & $\$ 1.42 / \mathrm{MMBtu}$ & $\$ 1.43 / \mathrm{MMBtu}$ & \$1.42/MMBtu & $\$ 1.74$ MMBtu & & s \\
\hline North CHP Plant Steam Revenue - Gas Trans Credit (\$) & 5 & & & & & & & & & & & & $\$$ \\
\hline tith C & 0 & 0 & 0 & 0 & 0 & 0 & 0 & 0 & 0 & 0 & 0 & & \\
\hline toru & - & - & - & - & -5 & -9 & s & - & $-\sigma_{-1}$ & 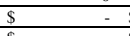 & -1 & & \\
\hline $\begin{array}{l}\text { North CHP Plant Steam Revenue }(\$ / 10001 \\
\end{array}$ & 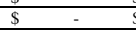 & $\underline{s}$ & & $\$$ & s. & $\$$ & $\$$ & s & $\$$ & $\$$ & s & $\$$ & $\$$ \\
\hline \\
\hline & $4,687,200$ & 1,500 & 7,200 & & 3,20 & & $35,1 c$ & & 6,000 & & & & \\
\hline & & & & & & & & & & & & & 1,0 \\
\hline & & & & & & & & & & & & & 5,572 \\
\hline & & & & & & & & & & $85 \%$ & $85 \%$ & $85 \%$ | & $85 \%$ \\
\hline Naturat & 5,774 & 3,919 & 5,774 & 5,587 & 5,774 & 80 & 4,478 & 5,774 & 5,587 & 5,774 & 5,587 & 5,774 & 65,379 \\
\hline Natural & \$6.37/MMBtu & /MMBtu & 5/MMBtu & SMMBtu & MMBtu & 9/MMBtu & 6MMBtu & 4/MMBtu & 3/MMBtu & 9/MMBtu & $\$ 3.96 / \mathrm{MMBtu}$ & \$4.65/MMBtu & 64/MMBtu \\
\hline South CHP Plant Steam Revenue - Gas Credit (\$) & 36,800 & 22,500 & 29,700 & 24,900 & $26,100 \mathrm{~s}$ & $23,900 \mathrm{~s}$ & 20,900 & 25,600 & 20,300 & 23,600 & $22,100 \mathrm{~s}$ & 26,800 & 303,200 \\
\hline & 5,774 & 19 & & 5,587 & & & 4,478 & & 87 & 5,774 & 587 & & $65,37 \mathrm{i}$ \\
\hline & & & & & & & & & & & & & \\
\hline Iransport & \$1.57/MMBtu & $\$ 1.57 / \mathrm{MMBtu}$ & $\$ 1.57 \mathrm{MMBtu}$ & \$1.28/MMBtu & $\$ 1.28 / \mathrm{MMBtu}$ & $\$ 1.28 \mathrm{MMBtu}$ & \$1.28/MMBtu & $\$ 1.28 / \mathrm{MMBtu}$ & MBtu & \$1.28/MMBtu & IMBtu & $\$ 1.5>>2010$ & \\
\hline & \$1.73/MMBtu & $\$ 1.81 / \mathrm{MMBtu}$ & \$1.73/MMBtu & \$1.43/MMBtu & $\$ 1.42 / \mathrm{MMBtu}$ & \$1.43/MMBtu & $\$ 1.45 / \mathrm{MMBtu}$ & \$1.42/MMBtu & $\$ 1.43 /$ MMBtu & \$1.42/MMBtu & \$1.74/MMBtu & \$1.73/MMBtu & $\$ 1.56 / \mathrm{MMBtu}$ \\
\hline 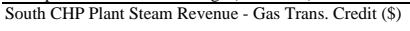 & 10,000 & 7,100 & 10,000 & $8,000 \$$ & $8,200 \mathrm{~s}$ & $8,000 \$$ & 6,500 & 8,200 & 8,000 & 8,200 & $9,700 \$$ & 10,000 & 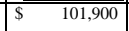 \\
\hline South CH & $4,687,200$ & $3,181,500$ & $4,687,200$ & $4,536,000$ & $4,687,200$ & $4,529,700$ & $3,635,100$ & $4,687,200$ & 4,53 & $4,687,200$ & $4,536,000$ & 7,200 & $53,077,500$ \\
\hline & 46,800 & 1,600 & 39,700 & $32,900 \$$ & $34,300 \mathrm{~s}$ & 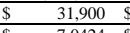 & $\$$ & $\frac{33,800}{7,211}$ & & 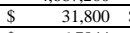 & 1000 & & $\frac{105,100}{76321}$ \\
\hline $1000 \mathrm{lb})$ & 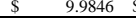 & $9.3038=5$ & 8.4699 & $7.2531 \mathrm{~s}$ & $7.3178 \mathrm{~s}$ & $7.0424 \mathrm{~s}$ & $7.5376 \mathrm{~s}$ & 7.2111 & 6.2390 & 6.7844 & 7.0106 & 7.8512 & 7.6322 \\
\hline \\
\hline & & & & & & & & & & & & & \\
\hline & 等 & & & & & & & & $\$$ & & & & 5,10 \\
\hline enue & , $800=5$ & 6000 & ,700 & 900 & $\begin{array}{l}4,300 \\
\end{array}$ & . & $\begin{array}{l}7,400 \\
\end{array}$ & 3,800 & 8,300 & 1,800 & 31,800 & 6,86 & \\
\hline
\end{tabular}




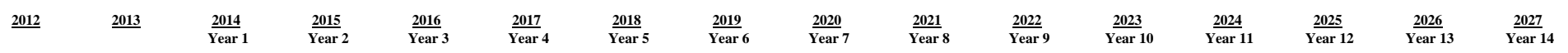

$\frac{\text { Steam Generation Capacity }}{\text { North CHP Plant Generation Capacity (lbshr) }}$

$\frac{\text { South CHP Plant Generation Capacity (lbshrir) }}{\text { Total Generation Capacity (lbshr) }}$

\begin{tabular}{rr}
0 & 0 \\
6,300 & 6,300 \\
\hline 6,300 & 6,300
\end{tabular}

0
6,300
6,300

0
6,300
6,300

0
6,300
6,300

0
6,300
6,300 $\begin{array}{r}0 \\ 6,300 \\ \hline\end{array}$

0
6,300
6,300
0
6,300
6,300 0
6,300
6,300 $\begin{array}{r}0 \\ 6,300 \\ \hline 6,300\end{array}$ 0
6,300
6,300 6,300 \begin{tabular}{rrr}
0 & 0 & 0 \\
6,300 & 6,300 & 6,300 \\
\hline 6,300 & 6,300 & 6,300
\end{tabular}

North CHP Plant Steam Generation (bs) South CHP Plant Steam Generation (lbs)

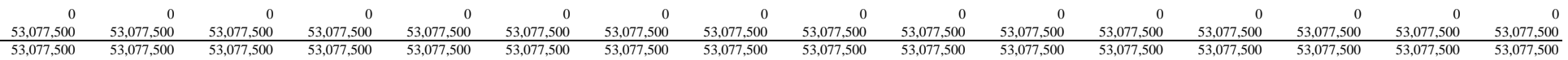
North CHP Plant Steam Revenues Steam Enthalpy (Btu/lb) Generation (MMBtu) txisting Boiler Efficiency (\%)

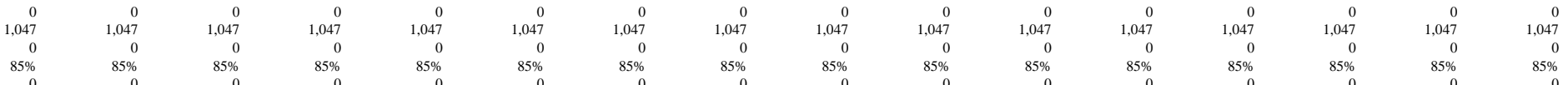
Natural Gas Unit Fuel Price City Gate (\$MMMBtu)

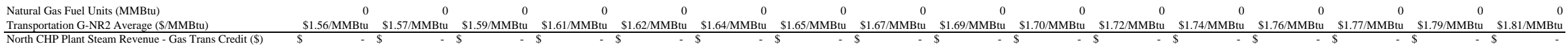

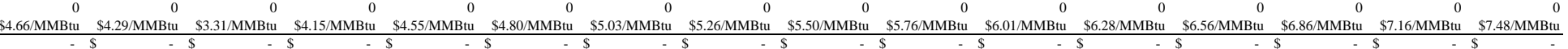

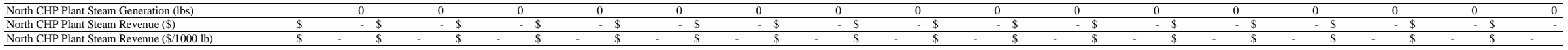

\section{South CHP Plant Steam Revenues} Steam Enthalpy (Btu/b) neration (MMBtu) Natural Gas Fuel Units (MMBtu)

Natural Gas Unit Fuel Price City Gate (\$/MMBtu)

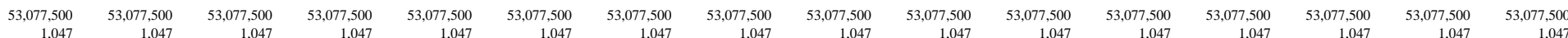

$\begin{array}{rrrrr}1,047 & 1,047 & 1,047 & 1,047 & 1,047 \\ 55,572 & 55,572 & 55,572 & 55,572 & 55,572\end{array}$

Natural Gas Fuel Units (MMBtu) ransportation G-NR2 Average (\$/MMBtu)

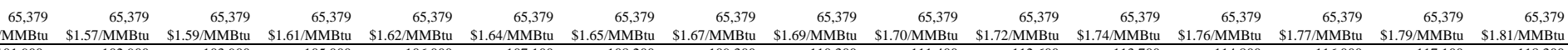

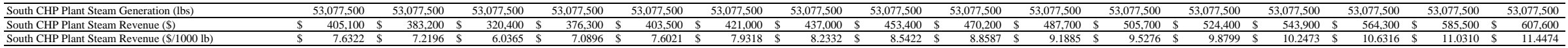

Total CHP Plant Steam Revenues

North CHP Plant Steam Revenue (S)

South CHP Plant Steam Revenue (\$) 
6.0a ANNUAL WASTE DISPOSAL REVENUES

Total CHP Plant Waste Disposal Revenues [1]

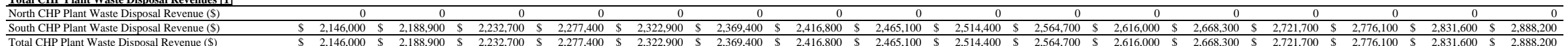

[1] Estimated to be $\$ 2,146,000$ annually, inflatted at $2.0 \%$ per year 


\begin{tabular}{|c|c|c|c|c|c|c|c|c|c|c|c|c|c|}
\hline & $\underline{\text { Jan }}$ & $\underline{\text { Feb }}$ & $\underline{\text { Mar }}$ & Apr & $\underline{\text { May }}$ & $\underline{\text { Jun }}$ & $\underline{\text { Jul }}$ & Aug & $\underline{\text { Sep }}$ & $\underline{\mathbf{O c t}}$ & Nov & Dec & $\underline{2012}$ \\
\hline \multicolumn{14}{|l|}{$\frac{\text { Electric Generation Capacity }}{\text { North CHP Plant Generation Capacity }(\mathrm{kW})}$} \\
\hline $\begin{array}{l}\text { North CHPP Plant Generation Capacaty }(\mathrm{k}) \mathrm{W} \text { - } \\
\text { South CHP Plant Genation Capacity }(\mathrm{kW})\end{array}$ & $\begin{array}{l}0 \\
1,764\end{array}$ & $\begin{array}{r}0 \\
1,764\end{array}$ & $\begin{array}{r}0 \\
1,764\end{array}$ & $\begin{array}{l}0 \\
1,764\end{array}$ & $\begin{array}{r}0 \\
1,764\end{array}$ & $\begin{array}{r}0 \\
1,764\end{array}$ & $\begin{array}{r}0 \\
1,764\end{array}$ & $\begin{array}{r}0 \\
1,764\end{array}$ & $\begin{array}{r}0 \\
1,764\end{array}$ & $\begin{array}{l}0 \\
1,764\end{array}$ & $\begin{array}{r}0 \\
1,764\end{array}$ & $\begin{array}{r}0 \\
1,764\end{array}$ & $\begin{aligned} 1,764 \\
\end{aligned}$ \\
\hline Total Generation Capacity $(\mathrm{kW})$ & 1,764 & 1,764 & 1,764 & 1,764 & 1,764 & 1,764 & 1,764 & 1,764 & 1,764 & 1,764 & 1,764 & 1,764 & 1,764 \\
\hline \multicolumn{14}{|l|}{ Electric Generation Energy } \\
\hline $\begin{array}{l}\text { North CHP Plant Generation }(\mathrm{kWh}) \\
\text { South CHP Plant Generation } \mathrm{kWhh}\end{array}$ & $\begin{array}{r}0 \\
12416\end{array}$ & $\begin{array}{r}0 \\
890.820\end{array}$ & $\begin{array}{r}0 \\
2416\end{array}$ & $\begin{array}{r}0 \\
270,08\end{array}$ & $\begin{array}{r}0 \\
1312416\end{array}$ & $\begin{array}{r}0 \\
1268316\end{array}$ & $\begin{array}{r}0 \\
1017828\end{array}$ & $\begin{array}{r}0 \\
1246\end{array}$ & $\begin{array}{r}0 \\
270,000\end{array}$ & $\begin{array}{r}0 \\
1246\end{array}$ & $\begin{array}{r}0 \\
70080\end{array}$ & $\begin{array}{r}0 \\
12446\end{array}$ & $\begin{array}{r}0 \\
1700\end{array}$ \\
\hline Total CHP Plant Generation $(\mathrm{kWh})$ & $\frac{\frac{1,132,416}{1,312,416}}{4}$ & 890,620 & $\frac{1,312,410}{1,312,416}$ & $\frac{1,270,000}{1,270,080}$ & $\frac{\frac{1,312,410}{1,312,416}}{4}$ & $\frac{\frac{1,200,310}{1,268,316}}{-10}$ & $\frac{\frac{1,001,020}{1,017,828}}{-1}$ & $\frac{\frac{1,312,410}{1,312,416}}{-10}$ & $1,270,080$ & $1,312,416$ & $1,270,080$ & $1,312,416$ & $\frac{14,001,700}{14,861,700}$ \\
\hline \multicolumn{14}{|l|}{ orth CHP Plant Production Costs } \\
\hline North CHP Plant Generation Capacity & 0 & 0 & 0 & 0 & 0 & 0 & 0 & 0 & 0 & 0 & 0 & & \\
\hline North CHP Plant Generation $(\mathrm{kWh})$ & 0 & 0 & 0 & 0 & 0 & 0 & 0 & 0 & 0 & 0 & 0 & & \\
\hline North CHP Plant Heat Rate HHV (Btu & 0 & 0 & 0 & 0 & 0 & 0 & 0 & 0 & 0 & 0 & 0 & & \\
\hline North CHP Plant Fuel C & & & & 0 & & & & & & & & & \\
\hline $\begin{array}{l}\text { Jatural Gas Unit Fuel Price City Gate (\$/MN } \\
\text { Jorth CHP Plant Natural Gas Fuel Cost (\$) }\end{array}$ & $\frac{\text { uMBtu }}{-\mathrm{s}}$ & & & & & & & & & & MMBtu & $\mathrm{MM}$ & MME \\
\hline $\begin{array}{l}\text { North CHP Plant Fuel Use HHV (MMBtu) } \\
\text { Transportation G-EG (SMMBtu) }\end{array}$ & $\begin{array}{r}0 \\
\text { S0.31/MMBtu } \\
\end{array}$ & $\begin{array}{r}0 \\
\text { MMBtu }\end{array}$ & $\begin{array}{r}0 \\
\text { amBtu }\end{array}$ & $\begin{array}{r}0 \\
\text { MBtu }\end{array}$ & $\begin{array}{r}0 \\
\text { MBtu }\end{array}$ & $\begin{array}{r}0 \\
\text { MMBtu }\end{array}$ & $\begin{aligned} 0 \\
\text { IBtu }\end{aligned}$ & $\begin{array}{r}0 \\
\text { MMBtu } \\
\end{array}$ & $\begin{array}{r}0 \\
\text { MMMBtu } \\
\end{array}$ & $\begin{array}{r}0 \\
31 / \text { MMBtu } \\
\end{array}$ & $\begin{array}{r}0 \\
\text { I/MMBtu }\end{array}$ & & UMB \\
\hline North CHP Plant Natural Gas Transportation Cost (\$) & $-s$ & 6.8 & & $-s$ & .8 & $-\$$ & & & .8 & & $s$ & & \\
\hline Total North CHP Plant Natural Gas Use (MMBtu) & 0 & & 0 & 0 & 0 & 0 & 0 & 0 & 0 & 0 & 0 & & \\
\hline \multirow{2}{*}{\multicolumn{14}{|c|}{ Total North CHP Plant Natural Gas Fuel Cost (S/MMBtu) }} \\
\hline & & & & & & & & & & & & & \\
\hline \multicolumn{14}{|l|}{$\underline{\text { South CHP Plant Production Costs }}$} \\
\hline South CHP Plant Gen & 1,764 & 1,764 & 1,764 & 1,764 & 1,764 & 1,764 & 1,764 & 1,764 & 1,764 & 1,764 & 1,764 & 1,764 & 1,764 \\
\hline South & $1,312,416$ & 890,820 & $1,312,416$ & $1,270,080$ & $1,312,416$ & $1,268,316$ & $1,017,828$ & $1,312,416$ & $1,270,080$ & $1,312,416$ & $1,270,080$ & $1,312,416$ & $14,861,700$ \\
\hline South $\mathrm{C}$ ( & 10,601 & 10,601 & 10,601 & 10,601 & 10,601 & 10,601 & 10,601 & 10,601 & 10,601 & 10,601 & 10,601 & 10,601 & $\begin{array}{r}10,601 \\
15748\end{array}$ \\
\hline GRO & 13,913 & 9,444 & 13,913 & 13,464 & 13,9 & 13,445 & 10,790 & 13,913 & 13,464 & 13, & 13,464 & & \\
\hline Maximum Waste to Fuel Natura & $\frac{12,648}{1265}$ & $\underline{11,424}$ & $\frac{12,648}{1265}$ & $\underline{12,240}$ & $\frac{12,648}{260}$ & $\frac{12,240}{20}$ & $\underline{12,648}$ & $\frac{12,648}{260}$ & $\frac{12,240}{221}$ & $\frac{12,648}{6,6}$ & $\underline{12,240}$ & $\underline{12,648}$ & $\underline{148,920}$ \\
\hline \multirow{2}{*}{$\frac{\text { Natural Gas Unit }}{\text { South CHP Plant }}$} & $\begin{array}{r}1,265 \\
7 M M B 4\end{array}$ & $\begin{aligned} 0 \\
3 \text { MMBtu }\end{aligned}$ & $\begin{array}{r}1,265 \\
M M B t\end{array}$ & 1,224 & 1,265 & 1,205 & $\begin{array}{r}0 \\
0\end{array}$ & 1,265 & 1,224 & 1,265 & 1,224 & 1,265 & 12,4 \\
\hline & $\frac{\mathrm{MMBStu}}{8,100 \mathrm{~S}}$ & & $\frac{\text { MMBtu }}{6,500 \$}$ & $\frac{\mathrm{MMBtu}}{5,500 \mathrm{~S}}$ & MMBtu $\$$ & $\begin{array}{ll}\text { MMBtu } \\
5,200 \$\end{array}$ & & $\begin{array}{ll}\text { MMMBtu } \\
5,600 \$\end{array}$ & $\frac{\text { MMBtu }}{4,400}$ & $\frac{\text { MMBtu }}{5,200 ~} \mathrm{~S}$ & $\frac{\text { MMBtu }}{4,800 \$}$ & $\frac{\text { MMBtu }}{5,900}$ & $\frac{4.56 / \mathrm{MMI}}{56,9}$ \\
\hline South CHP Plant & & & & & & & & & 1.224 & & 1.224 & & \\
\hline \multirow{2}{*}{$\frac{T \text { rransportation G-EG (SMMBitu) }}{\text { South CCPP Plant Natural Gas Transportation Cost (\$) }}$} & \$0.31/MMBtu & MMBtu & MMBtu & MMBtu & MMBtu & //MMBtu & MMBtu & 1/MMBtu & 1/MMBtu & 1/MMBtu & 31/MMBtu & $\$ 0.31 / \mathrm{MMBtu}$ & $\$ 0.32 / \mathrm{MMB}$ \\
\hline & $400 \mathrm{~s}$ & & $400 \$$ & $400 \mathrm{~s}$ & $400 \$$ & $400 \mathrm{~s}$ & $\$$ & $400 \$$ & $400 \$$ & $400 \$$ & $400 \$$ & 400 & 4,000 \\
\hline \multirow{3}{*}{\begin{tabular}{|l|} 
Total South CHP Plant Natural Gas Use (MMBtu) \\
Total Iouth CCPP Plant Natural Gas Fuel Cost (s) \\
Total South CHP Plant Natual Gas Fuel ( \\
\end{tabular}} & 1,265 & 0 & 1,265 & 1,224 & 1,265 & 1,205 & 0 & 1,265 & 1,224 & 1,265 & 1,224 & 1,265 & 12,466 \\
\hline & $8,500 \quad \$$ & $-\$$ & $6,900 \mathrm{\$}$ & $5,900 \mathrm{~s}$ & $6,100 \$$ & $5,600 \$$ & & $6,000 \$$ & $4,800 \mathrm{~s}$ & $5,600 \$$ & $5,200 \$$ & \begin{tabular}{ll|}
6,300 \\
\end{tabular} & 60,9 \\
\hline & \$6.72/MMBtu & & \$5.46/MMBtu & \$4.82/MMBtu & $\$ 4.82 / \mathrm{MMBtu}$ & $\$ 4.65 /$ MMBtu & & $\$ 4.74 /$ MMBtu & 2/MMBtu & \$4.43/MMBtu & \$4.25/MMBtu & YMBtu & \$4.89/MMI \\
\hline \multirow{2}{*}{\multicolumn{14}{|c|}{1,224}} \\
\hline \multirow{3}{*}{\begin{tabular}{|l} 
Total Natural Gas Fuel Cost (\$) \\
Total Natural Gas Fuel Cost (\$/MMBtu)
\end{tabular}} & & 0 & 1,265 & & & & 0 & 1,265 & 1,224 & 1,265 & 1,224 & 1,265 & \\
\hline & $8,500 \mathrm{~s}$ & $-\$$ & $6,900 \$$ & $5,900 \mathrm{~s}$ & $6,100 \$$ & $5,600 \mathrm{~s}$ & -5 & $6,000 \$$ & $4,800 \$$ & $5,600 \$$ & $5,200 \$$ & 6,300 & 60,90 \\
\hline & $\$ 6$ & & & & & & & & & & & & \\
\hline
\end{tabular}




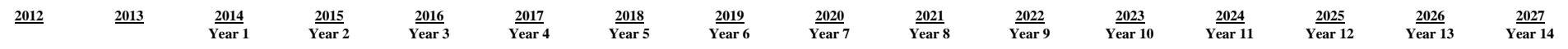

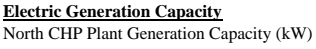

$\frac{\text { South CHP Plant Generation Capacity }(\mathrm{kW})}{\text { Total Generation Capacity }(\mathrm{kW})}$

\begin{tabular}{rr}
0 & 0 \\
764 & 1,764 \\
\hline 1,764 & 1,764
\end{tabular}

$\frac{\text { Electric Generation Energy }}{\text { North CHP Plant Generation }}$

South CHP Plant Generation (kWh) \begin{tabular}{rr}
0 & 0 \\
1,764 & 1,764 \\
\hline 1,764 & 1,764
\end{tabular} 0
1,764
1,764 0
1,764
1,764

0
1,764
1,764
$\begin{array}{r}0 \\ 1,764 \\ \hline 1,764\end{array}$ $\begin{array}{r}0 \\ 1,764 \\ \hline 1,764\end{array}$

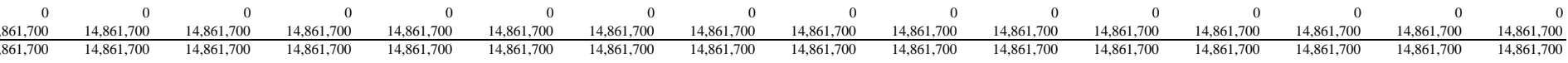

\section{North CHP Plant Production Costs}

North CHP Plant Generation Capacity $(\mathrm{kW})$

North CHP Plant Generation $(\mathrm{kWh})$
North CHP Plant Heat Rate HHV

North CHP Plant Fuel Use HHV (MMBtu)

$\frac{\text { Natural Gas Unit Fuel Price City Gate (S/MMBtu }}{\text { North CHP Plant Natural Gas Fuel Cos (S) }}$

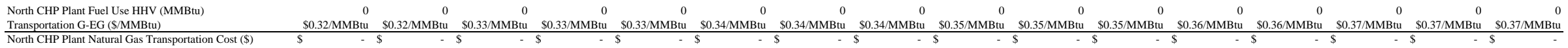

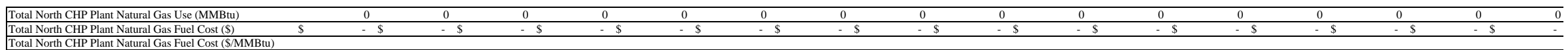

South CHP Plant Production Costs

apacity $(\mathrm{k}$

South CHP Plant Generation (kWh)
South CHP Plant Heat Rate HHV (Btu/kWh)

South CHP Plant Fuel Use HHV (MMBtu)

Natural Gas Unit Fuel Price City Gate (\$MMBBtu)

\begin{tabular}{|c|c|c|c|c|c|c|c|c|c|c|c|c|c|}
\hline $\begin{array}{r}1,764 \\
14,861,700\end{array}$ & & & $\begin{array}{r}1,764 \\
14,861,700\end{array}$ & $\begin{array}{r}1,764 \\
14,861,700\end{array}$ & $\begin{array}{r}1,764 \\
14,861,700\end{array}$ & $\begin{array}{r}1,764 \\
14,861,700\end{array}$ & $\begin{array}{r}1,764 \\
14,861,700\end{array}$ & $\begin{array}{r}1,764 \\
14,861,700\end{array}$ & $\begin{array}{r}1,764 \\
14,861,700\end{array}$ & $\begin{array}{r}1,764 \\
14,861,700\end{array}$ & & $\begin{array}{r}1,764 \\
14,861,700\end{array}$ & $\begin{array}{r}1,764 \\
14,861,700\end{array}$ \\
\hline & 10,601 & 10,601 & 10,601 & 10,601 & 10,601 & 10,601 & 10,601 & 10,601 & 10,601 & 10,601 & 10,601 & 10,601 & 10,601 \\
\hline
\end{tabular}

South CHP Plant Fuel Use HHV (MMBtu)

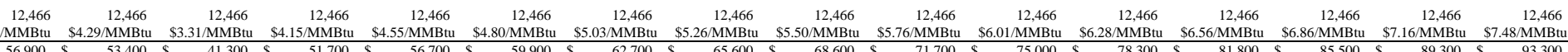

$\frac{\text { Transportation G-EG (\$MMMBtu) }}{\text { South CHP Plant Natural Gas Transportation Cost (\$) }}$

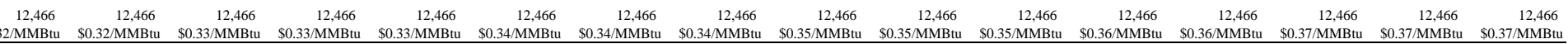

Total South CHP Plant Natural Gas Use (MMBtu)

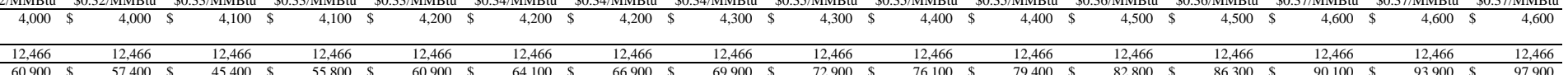

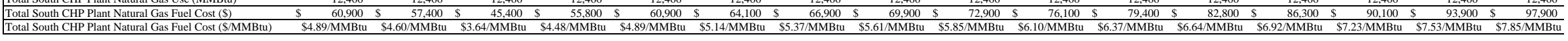

\section{Total CHP Plant Production Cost}

Total Natural Gas Fuel Use (MMB

\begin{tabular}{l} 
Total Natural Gas Fuel Cost (\$) \\
\hline Total Natural Gas Fuel Cost (\$MMBtu) \\
\hline
\end{tabular}

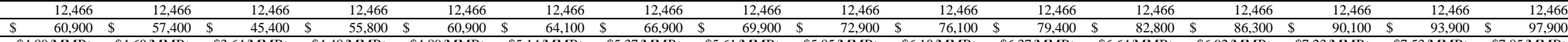

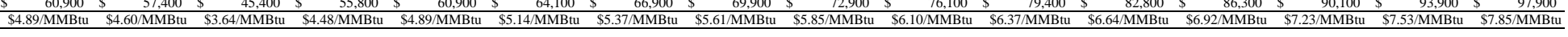




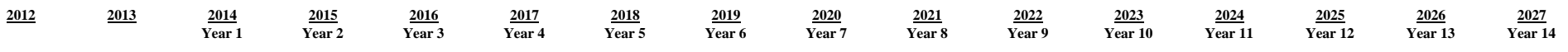
Incremental Labor Costs

\section{Management (Qty)}

Burdened Hourly Rate (Shr)

Escalation (\%)

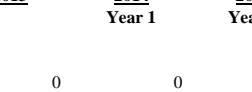

Additional Operators (Qty)
Burdened Hourly Rate (\$hr)

Burdened Hourly Rate (\$hr)
Escalation (\%)
Operator Labor Cost (\$)

\begin{tabular}{|c|c|c|}
\hline $\begin{array}{r}0 \\
100.00 \\
2.00 \%\end{array}$ & $\begin{array}{c}0 \\
102.00 \\
2.00 \%\end{array}$ & $\begin{array}{c}0 \\
104.04 \\
2.00 \%\end{array}$ \\
\hline
\end{tabular}

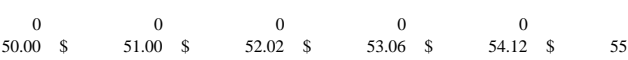

Escalation (\%)

Additional Maintenance Techs (Qty)
Burdened Hourly Rate (Shr)

Burdened Hourly Rate (\$/hr)
Escalation $(\%)$
Maintenance Techs Labor Cost (\$)

Total Additional Labor Cost (\$)

North Plant CHP Maintenance Cos

Number of Units
Prime Mover Maintenance Cost (\$/unit)

Escalation (\%)
Total Prime Mover Maintenance Cost (\$)

\section{South Plant CHP Maintenance Cost}

Prime Mover Maintenance Cost (\$/unit)

Escalation (\%)

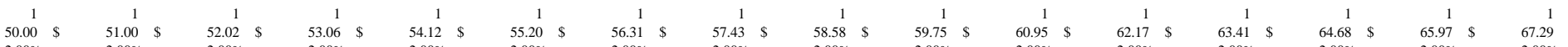

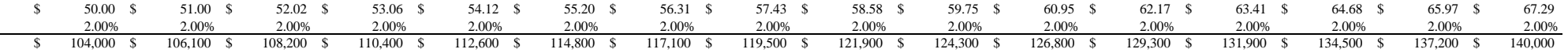
$\underline{\text { Total Additional Maintenance Cost }(\$)}$

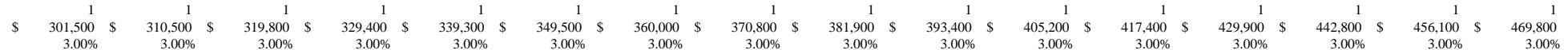

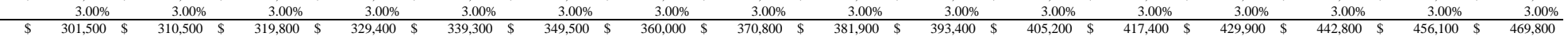

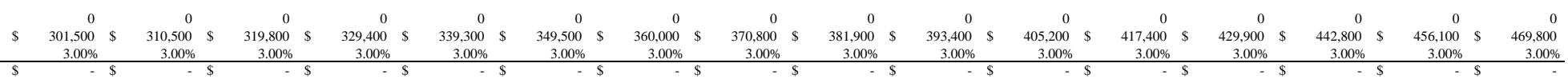

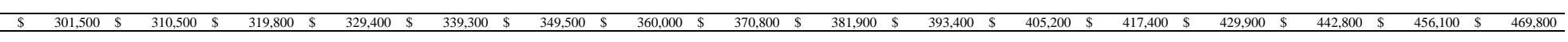




\section{$\frac{\text { Financing Assumption }}{\text { Debt Term (years) }}$} Interest Rate

Interest Rate
Investment Tax Credit
Capital Cost Capital Cost
Less SGIP Incentive

Less SGIP Incentive
Less Tax Credit

Financed Amount

Debt Financed

Equity Financed
Total Debt Financing

Long Term Financing

Amount to Finance

Beginning Year Balance
Interest

Interest
Principal

Principal

End of Year Balance $\underline{2012}$

$\underline{2013}$

$\frac{2015}{\text { Year } 2}$

$\frac{2016}{\text { Year } 3}$

Year

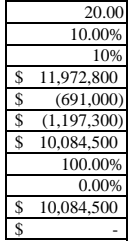

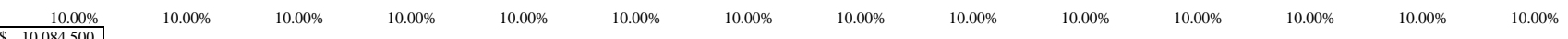

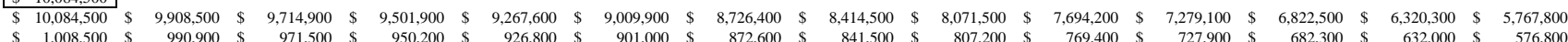

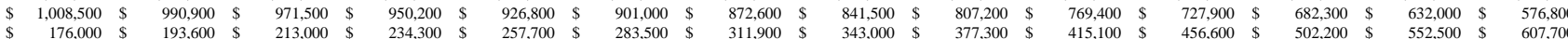

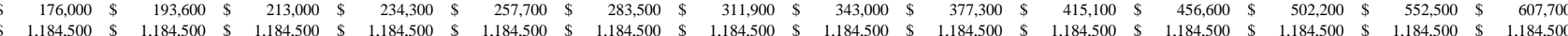

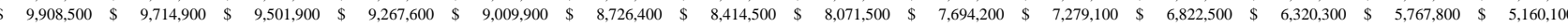


10.0 DEPRECIATION

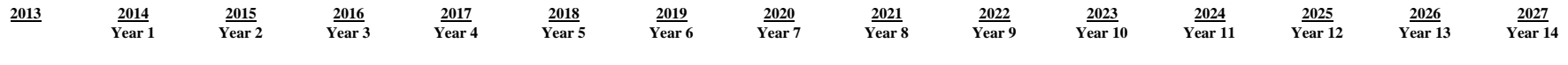

Capital Cost

Less SGIP Incentive
Less Tax Credit

Depreciable Basis

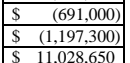

Year 5 Year

Year 7 (x)

\begin{tabular}{l}
$\$(1,197,300)$ \\
\hline MACR2 5 -Year \\
\hline
\end{tabular}

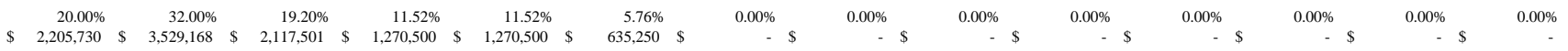
Depreciation Percentage
Depreciation Expense

[1] Depreciable Basis is equal to total project cost less the tax credits and rebate for which the project qualifies. 


\subsection{PRO FORMA}

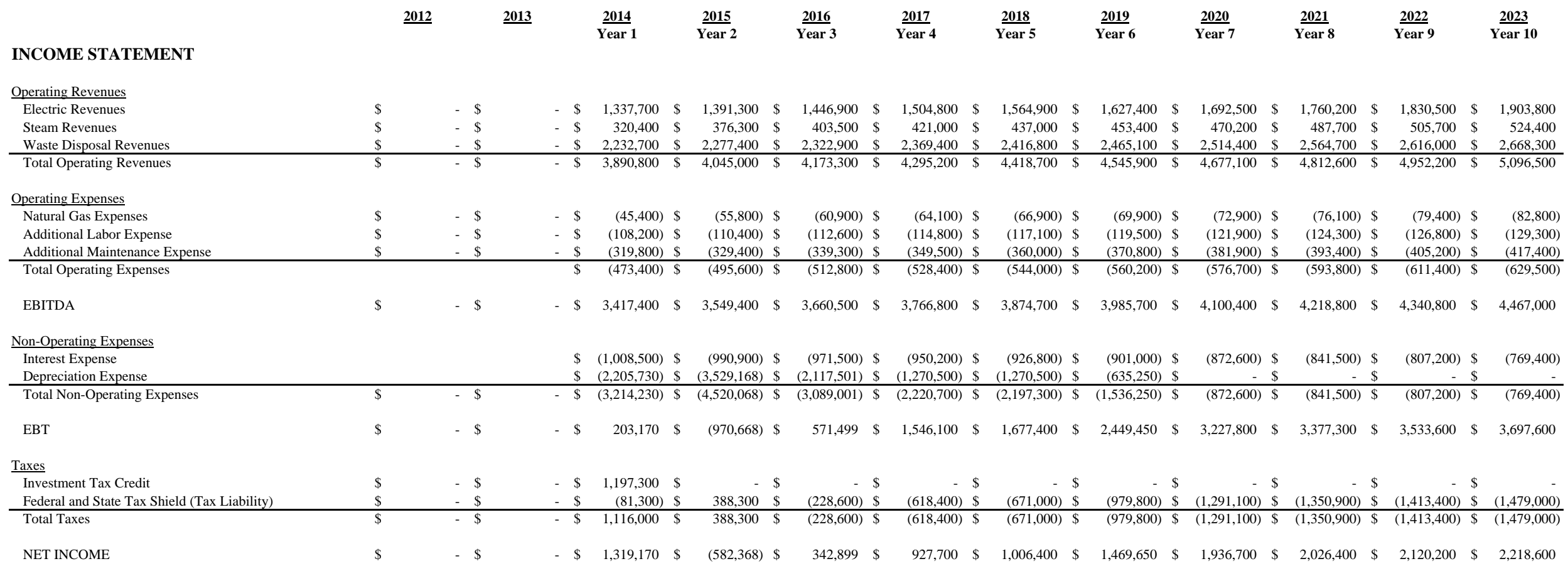

\section{CASH FLOW STATEMENT}

Cash Flows Operating Activitie

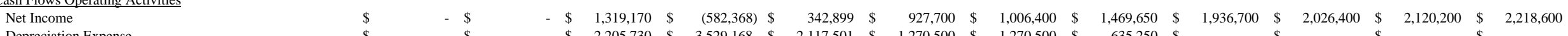
\begin{tabular}{l} 
Depreciation Expense \\
\hline Net Cash Flows Operating Activities
\end{tabular}

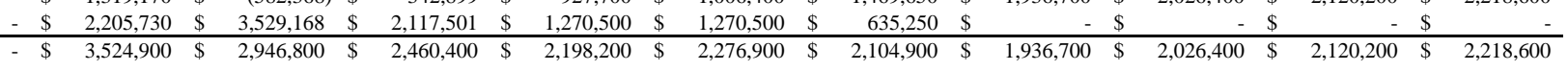

Cash Flows Capital Financing and Investing Activities

\begin{tabular}{lcc} 
& & \\
\hline Proceeds From SGIP Rebate & $\$ 991,000$ \\
Proceeds From Debt & $\$ 10,084,500$ \\
Capital Acquisition Payments & $\$(11,972,800)$ \\
\hline
\end{tabular}

$\begin{array}{lllllllllll} & \end{array}$

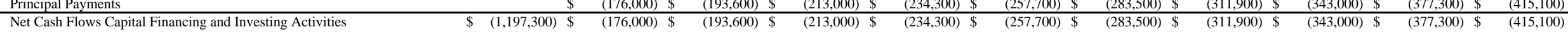

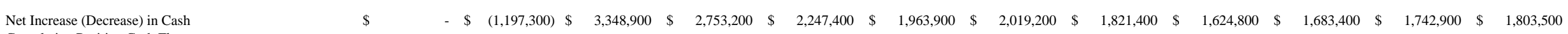
Cumulative Positive Cash Flows

Net Present Value

$\$ 12,874,100$

Discount Rate 
OPTION 3 - SINGLE CHP PLANT WITH RECIPROCATING ENGINES 


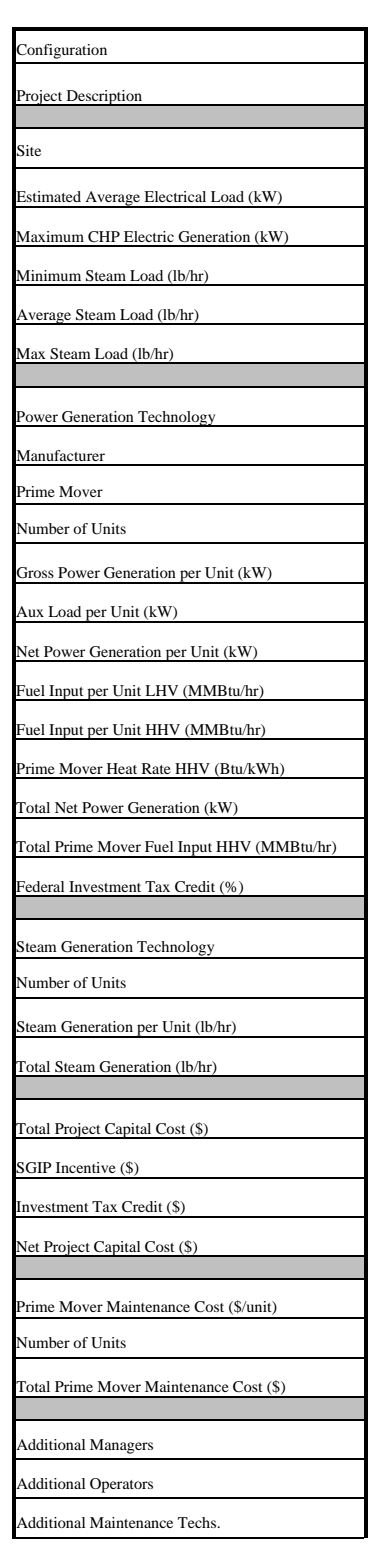

\begin{tabular}{|c|c|c|}
\hline \multicolumn{3}{|c|}{ SELECT CONFIGURATION } \\
\hline \multicolumn{3}{|c|}{ Option 3} \\
\hline \multicolumn{3}{|c|}{$\begin{array}{l}\text { Single CHP Plant Located at South Site - No Steam } \\
\text { Interconnection }\end{array}$} \\
\hline North Site & South Site & Total \\
\hline 0 & 1,500 & 1,500 \\
\hline 0 & 5,000 & 5,000 \\
\hline$\underline{0}$ & 7,000 & 7,000 \\
\hline 0 & 15,000 & 15,000 \\
\hline 0 & 25,000 & 25,000 \\
\hline 0 & $\begin{array}{c}\text { Reciprocating } \\
\text { Engine }\end{array}$ & \begin{tabular}{|l|} 
Reciprocating \\
Engine
\end{tabular} \\
\hline 0 & GE & GE \\
\hline 0 & \begin{tabular}{|l|l} 
Jenbacher JMS \\
416
\end{tabular} & \begin{tabular}{|c|} 
Jenbacher JMS \\
416
\end{tabular} \\
\hline 0 & 2 & 2 \\
\hline 0 & 1,137 & 1,137 \\
\hline 0 & -23 & -23 \\
\hline 0 & 1,114 & 1,114 \\
\hline 0.00 & 9.78 & 9.78 \\
\hline 0.00 & 10.75 & 10.75 \\
\hline 0 & 9,651 & 9,651 \\
\hline 0 & 2,229 & 2,229 \\
\hline 0.0 & 21.5 & 21.5 \\
\hline $0 \%$ & $10 \%$ & $10 \%$ \\
\hline 0 & HRSG & HRSG \\
\hline 0 & 2 & 2 \\
\hline 0 & 2,231 & 2,231 \\
\hline 0 & 4,462 & 4,462 \\
\hline$\$$ & s $\quad 10,032,100$ & S $\quad 10,032,100$ \\
\hline$\$$ & $\$ \quad(529,100)$ & s $\quad(529,100)$ \\
\hline$\$$ & $\$ \quad(1,003,200)$ & \& $\quad(1,003,200)$ \\
\hline$\$$ & s $\quad 8,499,800$ & $\$ \quad 8,499,800$ \\
\hline s & s $\quad 137,100$ & \& $\quad 137,100$ \\
\hline $\mathbf{0}$ & 2 & 2 \\
\hline s & s $\quad 274,200$ & \$ $\quad 274,200$ \\
\hline 0 & 0 & $\mathbf{0}$ \\
\hline 0 & 0 & 0 \\
\hline 0 & 1 & 1 \\
\hline
\end{tabular}
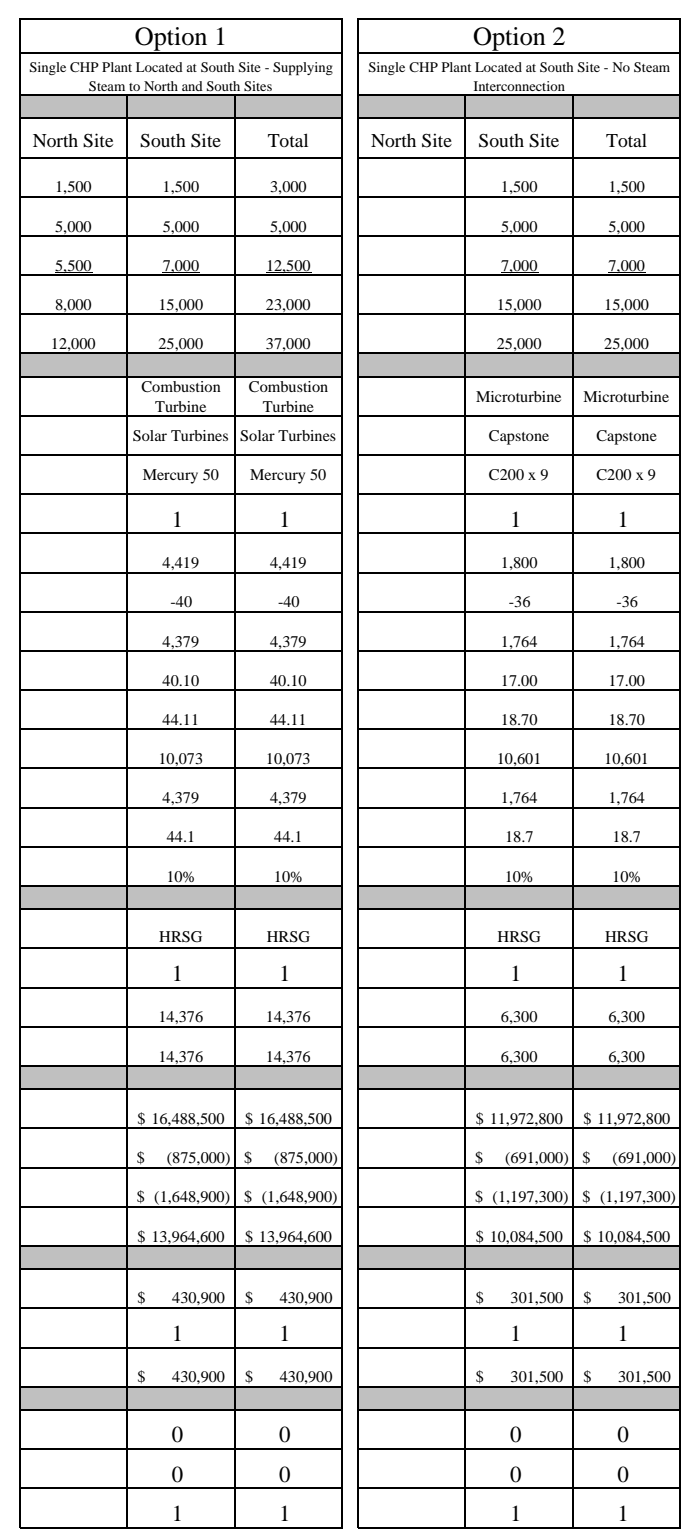

\begin{tabular}{|c|c|c|}
\hline \multicolumn{3}{|c|}{ Option 3} \\
\hline \multicolumn{3}{|c|}{$\begin{array}{l}\text { Single CHP Plant Located at South Site - No Steam } \\
\text { Interconnection }\end{array}$} \\
\hline North Site & South Site & Total \\
\hline & 1,500 & 1,500 \\
\hline & 5,000 & 5,000 \\
\hline & 7,000 & 7.000 \\
\hline & 15,000 & 15,000 \\
\hline & 25,000 & 25,000 \\
\hline & $\begin{array}{c}\text { Reciprocating } \\
\text { Ennine }\end{array}$ & $\begin{array}{l}\text { Reciprocating } \\
\text { Ennine }\end{array}$ \\
\hline & GE & GE \\
\hline & $\begin{array}{l}\text { Jenbacher JMS } \\
446\end{array}$ & $\begin{array}{l}\text { Jenbacher JMS } \\
446\end{array}$ \\
\hline & 2 & 2 \\
\hline & 1,137 & 1,137 \\
\hline & -23 & -23 \\
\hline & 1,114 & 1,114 \\
\hline & 9.78 & 9.78 \\
\hline & 10.75 & 10.75 \\
\hline & 9,651 & 9,651 \\
\hline & 2,229 & 2,229 \\
\hline & 21.5 & 21.5 \\
\hline & $10 \%$ & $10 \%$ \\
\hline & HRSG & HRSG \\
\hline & 2 & 2 \\
\hline & 2,231 & 2,231 \\
\hline & 4,462 & 4,462 \\
\hline & $\$ 10,032,100$ & $\$ 10,032,100$ \\
\hline & $\$(529,100)$ & $\begin{array}{l}S \quad(529,100) \\
\end{array}$ \\
\hline & $\$$ & $S(1,003,200)$ \\
\hline & \$ $8,499,800$ & S $8,499,800$ \\
\hline & $\$ \quad 137,100$ & $\begin{array}{ll}\text { S } & 137,100\end{array}$ \\
\hline & 2 & 2 \\
\hline & $\$ \quad 274,200$ & $\$ \quad 274,200$ \\
\hline & 0 & 0 \\
\hline & 0 & 0 \\
\hline & 1 & 1 \\
\hline
\end{tabular}




\begin{tabular}{l} 
Gas Price SMMBtu [1] \\
January \\
February \\
March \\
April \\
May \\
June \\
July \\
August \\
September \\
October \\
November \\
December \\
\hline Average
\end{tabular}

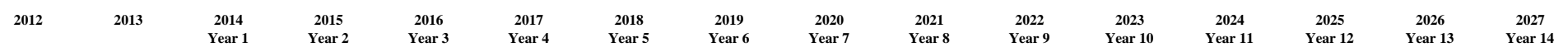

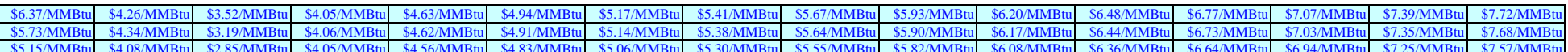

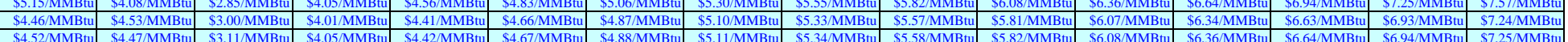

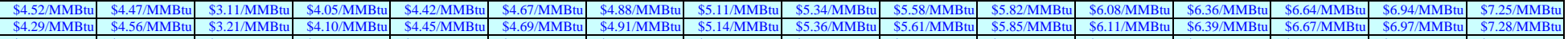

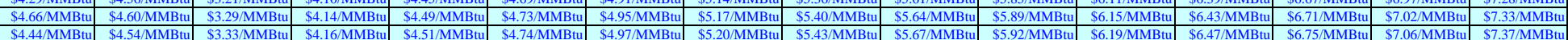

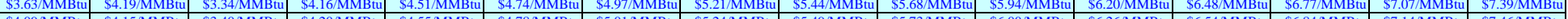

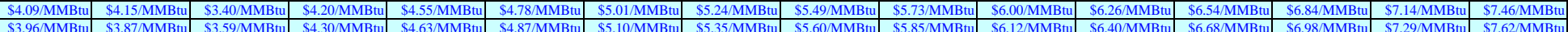

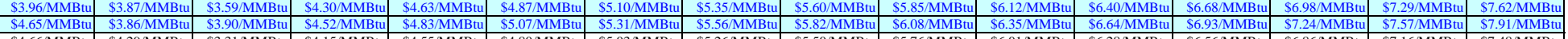

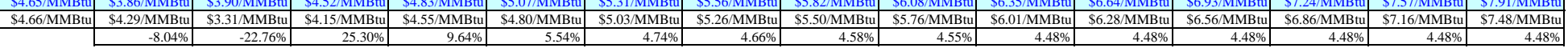

On Peak Energy (\$MWh) [2]

Jebruary

April
May
June

July

August
September

September

November

$\frac{\text { December }}{\text { Average On Peak (\$MWh) }}$

\begin{tabular}{|c|c|c|c|c|c|c|c|c|c|c|c|c|c|c|c|}
\hline $6.91 / \mathrm{MWh}$ & 1 & $\mathrm{Wh}$ & III & (N) & GWh & 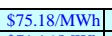 & $.91 / \mathrm{MWh}$ & $39 / \mathrm{MWh}$ & 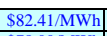 & 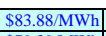 & $\$ 85.68 / \mathrm{MWh}$ & $\$ 86.77 / \mathrm{MWh}$ & \$899.39/MWh & \$91.89/MWh & 994.58 \\
\hline $84 / \mathrm{MWh}$ & $\$ 67.60 / \mathrm{MWh}$ & 4.98/MWh & $\$ 66.25 / \mathrm{MWh}$ & $\$ 69.43 / \mathrm{MWh}$ & $\$ 69.52 \mathrm{MWh}$ & $1.16 / \mathrm{MWh}$ & & $\$ 76.09 / \mathrm{MWh}$ & wn & $\$ 79.39 / \mathrm{MWh}$ & & & $884.61 / \mathrm{MWh}$ & & \\
\hline $4.20 / \mathrm{MV}$ & $\begin{array}{l}865.86 / 1 \\
5077070\end{array}$ & & $\$ 63.78 / \mathrm{MWh}$ & $\$ 66.85 / \mathrm{MWh}$ & $\$ 66.93 / \mathrm{MWh}$ & $\begin{array}{l}868.50 / \mathrm{MWh} \\
8.159\end{array}$ & $\$ 71.91 / \mathrm{MWh}$ & $\begin{array}{l}\$ 73.25 \\
c .20\end{array}$ & MWh & 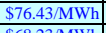 & MWh f & $\overline{\mathrm{Nh}}$ & $1.46 / \mathrm{MWh}$ & $3.73 / \mathrm{MWh}$ & $18 \mathrm{MWh}$ \\
\hline $6.60 / \mathrm{MWh}$ & & $\$ 55.16 /$ & $\$ 56.9$ & & & \$61.15/MWh & $\$ 64.19 / \mathrm{MWh}$ & & & $\$ 68.23 / \mathrm{MWh}$ & & & & & $\overline{\mathrm{nWh}}$ \\
\hline MWh & $\frac{859.19 / \mathrm{MWh}}{\$ 6631 \mathrm{MWh}}$ & $\frac{\$ 54.87 / \mathrm{MWh}}{\$ 55899 \mathrm{MW}}$ & $\frac{856.73 / \mathrm{MWh}}{\$ 66.09 \mathrm{MWh}}$ & $\frac{859.46 / \mathrm{MWh}}{86.91 \mathrm{MWW}}$ & $\frac{\$ 59.54 / \mathrm{MWh}}{\$ 66.00 \mathrm{MWh}}$ & 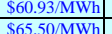 & 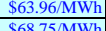 & $\$ 65.16 / \mathrm{MWh}$ & $\$ 66.80 / \mathrm{MWh}$ & $\frac{\$ 67.99 / \mathrm{MWh}}{S 730}$ & 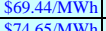 & 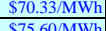 & $\$ 72.46 / \mathrm{MWh}$ & $\$ 874.48 / \mathrm{MWh}$ & $\frac{6.66 / \mathrm{MWh}}{200(5)}$ \\
\hline & & & & & & & & & & & & & & & 40MWh \\
\hline & & & & & & & & & & & & & & & \\
\hline & $\frac{M v}{14}$ & 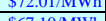 & $\frac{8 t}{S 7}$ & 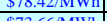 & 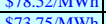 & 5010 & $\frac{38.453 / 1}{9620}$ & 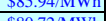 & 380 & 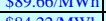 & $\frac{S 91.59}{9032}$ & $\frac{S 9.216}{9071}$ & $x_{2}$ & & \\
\hline 866.8 & & 9641 & & & 570 & & & $38 / M$ & & & & & $\overline{41}$ & $\$ 8844 \sqrt{1}$ & $\frac{1}{4}$ \\
\hline & & & & & & & & & & & & & & & \\
\hline & & & & & & & & & & & & & & & \\
\hline & $\$ 68.25 / \mathrm{N}$ & $\$ 64.29 / \mathrm{MWh}$ & $\$ 66.74 / \mathrm{MWh}$ & $\$ 69.94 / \mathrm{MWh}$ & $\$ 70.04 / \mathrm{MWh}$ & IWh & S75.24/MWh & $\$ 876.65 \mathrm{MWh}$ & $\$ 57.58 \mathrm{MWh}$ & S79.98/MWh & $\$ 81.69 \mathrm{MWh}$ & $\begin{array}{l}\text { S82.74/MWh } \\
\end{array}$ & MWh & $\$ 87.61 \mathrm{MWh}$ & $590.18 \mathrm{MWh}$ \\
\hline
\end{tabular}

Off Peak Energy (S/MWh) [2]

January
February

April
May

June

August
September

October
Novemb

Dovember

December

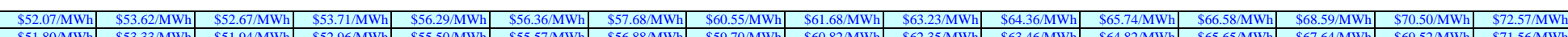

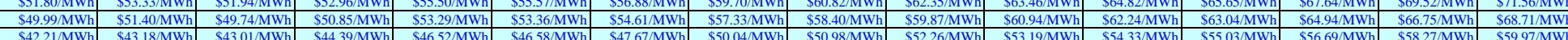

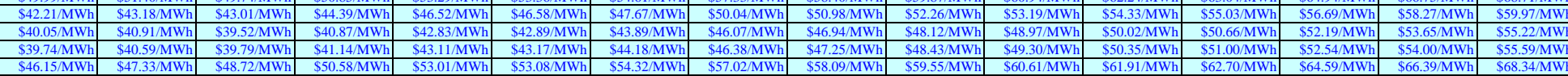

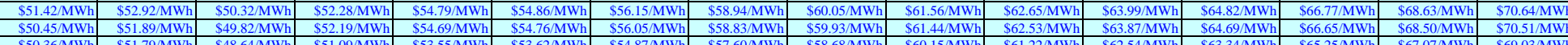

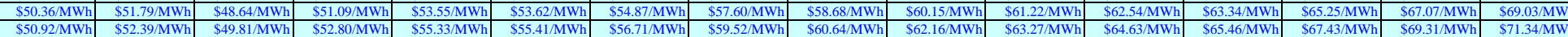

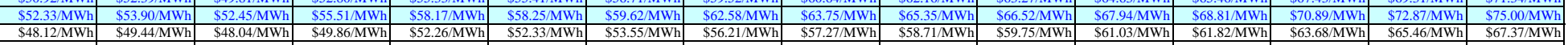

[1] Source: Correlation to Henry Hub futures pricing.
[2] Source: SMUD forecast, prior study. 


\begin{tabular}{|c|c|c|c|c|c|c|c|c|c|c|c|c|c|}
\hline & January & February & March & $\frac{\text { April }}{30}$ & $\frac{\text { Mav }}{31}$ & $\frac{J \text { June }}{30}$ & $\frac{\mathrm{Jull}}{31}$ & August & September & $\begin{array}{l}\text { October } \\
\text { al }\end{array}$ & November & \begin{tabular}{l|l} 
December \\
\end{tabular} & $\begin{array}{ll}\frac{\text { Total }}{365} \\
65\end{array}$ \\
\hline Energy Consumption $(\mathrm{kWh})$ & $\frac{31}{1,806,040}$ & \begin{tabular}{l|}
28 \\
$1,654,580$
\end{tabular} & $\frac{31}{1,938,140}$ & $\frac{30}{1,874,520}$ & $\frac{31}{2,046,370}$ & $\frac{30}{2,063,900}$ & $\frac{31}{2,224,920}$ & $\frac{31}{2,237,190}$ & $\frac{30}{2,192,432}$ & \begin{tabular}{|l|}
31 \\
$2,064,750$
\end{tabular} & $\begin{array}{c}30 \\
1,873,760\end{array}$ & $\frac{31}{1,772,930}$ & $\begin{array}{c}335 \\
23,749,532\end{array}$ \\
\hline Pealon & 3,104 & 3,148 & 3,331 & 3,329 & 3,430 & 3,763 & 3,822 & 3,845 & 3,894 & 3,549 & 3,328 & 3,047 & 3,894 \\
\hline Average & 2,427 & 2,462 & 2,605 & 2,604 & 2,750 & 2,867 & 2,990 & 3,007 & 3,045 & 2,775 & 2,602 & 2,383 & 2,710 \\
\hline Min Demand $(\mathrm{kW})$ & 1,751 & 1,776 & 1,879 & 1,878 & 2,071 & 1,970 & 2,159 & 2,169 & 2,196 & 2,002 & 1,877 & 1,719 & 1,719 \\
\hline Load Factor (\%) & $78.20 \%$ & $78.20 \%$ & $78.20 \%$ & $78.20 \%$ & $80.18 \%$ & $76.17 \%$ & $78.25 \%$ & $78.20 \%$ & $78.20 \%$ & $78.20 \%$ & $78.20 \%$ & $78.20 \%$ & \\
\hline Dayti & 4 & & & & & & 17 & 45 & 3,894 & 49 & 3,328 & 3,047 & 3, \\
\hline Daytime Energy (kWh) & $1,154,715$ & $1,057,877$ & $1,239,175$ & $1,198,499$ & $1,276,086$ & $1,354,729$ & $1,421,617$ & $1,430,376$ & $1,401,760$ & 1,320,125 & 1,198,013 & 1,133,546 & 86, \\
\hline $\begin{array}{l}\text { Nighttime Load (kW) } \\
\text { Nighttime Energy (kWh) }\end{array}$ & $\begin{array}{r}1,751 \\
651,325\end{array}$ & $\begin{array}{c}1,776 \\
596,703\end{array}$ & $\begin{array}{r}1,879 \\
698,965\end{array}$ & $\begin{array}{r}1,878 \\
676,021\end{array}$ & $\begin{array}{r}2,071 \\
770,284\end{array}$ & $\begin{array}{r}1,970 \\
709,171\end{array}$ & $\begin{array}{r}2,159 \\
803,303\end{array}$ & $\begin{array}{r}2,169 \\
806,814\end{array}$ & $\begin{array}{r}2,196 \\
790,672\end{array}$ & $\begin{array}{r}2,002 \\
744,625\end{array}$ & $\begin{array}{r}1,877 \\
675,747\end{array}$ & $\begin{array}{r}1,719 \\
639,384\end{array}$ & 63,016 \\
\hline Total Energy (kWh) & 1806,040 & 1654580 & 1938,140 & 1874.520 & 2046,370 & 2063,900 & $2,224,920$ & 2.237,190 & $2,192,432$ & 2064,750 & 1873.760 & 1.772930 & 749 \\
\hline
\end{tabular}

\begin{tabular}{|c|c|c|c|c|c|c|c|c|c|c|c|c|c|}
\hline STEAM LOAD SUMMARY & January & February & $\underline{\text { March }}$ & April & $\underline{\underline{\text { May }}}$ & $\underline{\text { June }}$ & July & August & September & October & November & December & $\underline{\text { Total }}$ \\
\hline North Site & & & & & & & & & & & & & \\
\hline $\begin{array}{l}\text { North Natural Gas (Therms) } \\
\text { North Natural Gas (MMBtut) }\end{array}$ & $\begin{aligned} 38,086 \\
3,809\end{aligned}$ & $\begin{array}{r}36,124 \\
3,612\end{array}$ & $\begin{array}{r}37,454 \\
3,745\end{array}$ & $\begin{array}{r}34,796 \\
3,480\end{array}$ & $\begin{array}{l}34,866 \\
3487\end{array}$ & $\begin{array}{l}30,282 \\
3028\end{array}$ & $\begin{array}{l}30,596 \\
3360\end{array}$ & $\begin{array}{l}30,095 \\
3010\end{array}$ & $\begin{array}{l}28,610 \\
281\end{array}$ & 33,131 & $\begin{array}{l}36,661 \\
366\end{array}$ & 38,086 & 408,787 \\
\hline 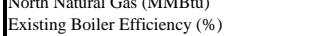 & $\frac{3,809}{85 \%} \mid$ & $\frac{3,612}{85 \%}$ & $\begin{array}{l}3,45 \\
85 \%\end{array}$ & $\begin{array}{l}3,480 \\
85 \%\end{array}$ & $\frac{3,487}{85 \%} \mid$ & $\frac{3,02 \%}{85 \%}$ & $\frac{3,000}{85 \%}$ & $\frac{3,010}{85 \%}$ & $\mid \frac{2,001}{85 \%}$ & $\frac{3,313}{85 \%} \mid$ & $\frac{3,000}{85 \%} \mid$ & (3,009 & $85 \%$ \\
\hline Steam Production (MMBtu) & 3,237 & 3,071 & 3,184 & 2,958 & 2,964 & 2,574 & 2,601 & 2,558 & 2,432 & 2,816 & 3,116 & 3,237 & 34,747 \\
\hline Steam Enthalpy (Btu/b) & 1,047 & 1,047 & 1,047 & 1,047 & 1,047 & 1,047 & 1,047 & 1,047 & 1,047 & 1,047 & 1,047 & 1,047 & 1,047 \\
\hline Steam Production (bs) & $3,091,979$ & $2,932,695$ & $3,040,711$ & $2,824,898$ & $2,830,573$ & $2,458,400$ & $2,483,948$ & $2,443,275$ & $2,322,668$ & $2,689,702$ & $2,976,266$ & $3,091,979$ & $33,187,093$ \\
\hline$\underline{\text { South } S}$ & & & & & & & & & & & & & \\
\hline South Natural Gas (Therms) & 88,867 & 84,289 & 87,394 & 81,191 & 81,354 & 70,657 & 71,392 & 70,223 & 66,756 & 77,305 & 85,541 & 88,867| & \\
\hline $\begin{array}{l}\text { Extsing Boller EEtfleneycy (\%) } \\
\text { Steam Production (MMBtu) }\end{array}$ & $\frac{85 \% \mid}{7,554}$ & $\frac{85 \% \mid}{7165} \mid$ & $\frac{85 \% \mid}{7428}$ & $\frac{85 \% \mid}{6901}$ & $\frac{85 \% \mid}{6.915}$ & $\frac{85 \% \text { | }}{60006}-2$ & $\frac{85 \% \mid}{6068}$ & $\frac{85 \% \mid}{5.969}$ & $\frac{85 \% \mid}{5674}$ & $\frac{85 \% \mid}{6571} \mid$ & $85 \%$ & 7551 & $85 \%$ \\
\hline Steam Enthalpy (Bt & $\frac{1,554}{1,147}$ & $\begin{array}{l}7,165 \\
1,147\end{array}$ & $\begin{array}{l}7,428 \\
1,147\end{array}$ & 6,901 & 6,915 & 6,006 & 6,068 & 5,969 & 5,674 & 6,571 & $\begin{array}{l}7,271 \\
1,147\end{array}$ & , 1,554 & $\begin{array}{l}81,076 \\
1,147\end{array}$ \\
\hline Steam Production (lbs) & $6,585,618$ & $6,246,359$ & $6,476,422$ & $6,016,762$ & $6,028,849$ & $5,236,156$ & $5,290,572$ & $5,203,942$ & $\begin{array}{l}4,147,059 \\
4,949\end{array}$ & $5,728,807$ & $6,339,162$ & \begin{tabular}{r|r|r|r|}
$6,585,618$ \\
\end{tabular} & $70,685,326$ \\
\hline Total Natural C & 126,953 & \begin{tabular}{|c|}
120,413 \\
\end{tabular} & \begin{tabular}{|l|l|}
124,848 \\
\end{tabular} & 115,987 & 116,220 & 100,939 & 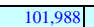 & 100,318 & 95,366 & 110,436 & 122,202 & 126,953 & $1,362,623$ \\
\hline Total Natural C & 12,695 & & 12,485 & 11,599 & 11,622 & 10,094 & 10,199 & 10,032 & 9,537 & 11,044 & 12,220 & 12,695 & 136,262 \\
\hline Total Steam Demand (MMBtu) & 10,791 & 10,235 & 10,612 & 9,859 & 9,879 & 8,580 & 8,669 & 8,527 & 8,106 & 9,387 & 10,387 & 10,791 . & 115,823 \\
\hline Total Steam Demand (lbs) & $9,677,596$ & $9,179,054$ & $9,517,133$ & $8,841,661$ & $8,859,422$ & $7,694,555$ & $7,774,520$ & $7,647,217$ & $7,269,727$ & $8,418,509$ & $9,315,429$ & $9,677,596$ & $103,872,419$ \\
\hline
\end{tabular}

4.1 CHP DISPATCH SUMMARY

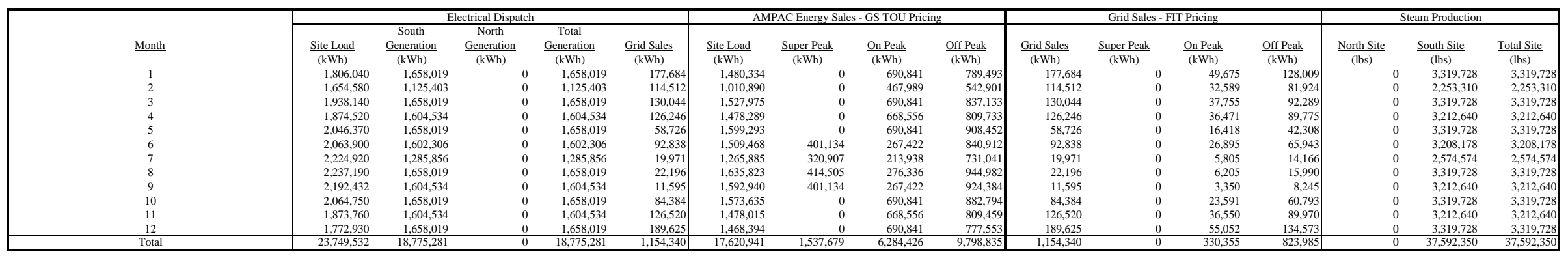




\begin{tabular}{|c|c|c|c|c|c|c|c|c|c|c|c|c|c|c|}
\hline & & $\underline{\text { Jan }}$ & $\underline{\text { Feb }}$ & Mar & Apr & $\underline{\text { May }}$ & $\underline{\text { Jun }}$ & Jul & Aug & $\underline{\text { Sep }}$ & $\underline{\text { oct }}$ & Nov & $\underline{\text { Dec }}$ & $\underline{2012}$ \\
\hline$\frac{\text { Electric Generation Capacity }}{\text { North CHP Plant Generation Capacity }(\mathrm{kW})}$ & & & & & & & & & & & & & & \\
\hline $\begin{array}{l}\text { Notrth CHPP Plant Generation Capacictyt (kW) } \\
\text { South CHP Plant Generation Capacity }(k W)\end{array}$ & & 2,229 & $\begin{array}{r}0 \\
2,229\end{array}$ & $\begin{array}{r}0 \\
2,229\end{array}$ & 2,229 & $\begin{array}{r}0 \\
2,229\end{array}$ & $\begin{array}{r}0 \\
2,229\end{array}$ & $\begin{array}{r}0 \\
2,229\end{array}$ & 2,229 & 2,229 & $\begin{array}{r}0 \\
2,229\end{array}$ & 2,229 & 2,229 & 2,229 \\
\hline Total Generation Capacity (kW) & & 2,229 & 2,229 & 2,229 & 2,229 & 2,229 & 2,229 & 2,229 & 2,229 & 2,229 & 2,229 & 2,229 & 2,229 & 2,229 \\
\hline Electric Generation Energy & & & & & & & & & & & & & & \\
\hline $\begin{array}{l}\text { North CHP Plant Generation }(\mathrm{kWh}) \\
\text { South CHP Plant Generation }(\mathrm{kWh})\end{array}$ & & $\begin{array}{r}0 \\
1,658,019\end{array}$ & $\begin{array}{r}0 \\
1,125,403\end{array}$ & $\begin{array}{r}0 \\
1,658,019\end{array}$ & $\begin{array}{r}0 \\
1,604,534\end{array}$ & $\begin{array}{r}0 \\
1,658,019\end{array}$ & $\begin{array}{r}0 \\
1,602,306\end{array}$ & $\begin{array}{r}0 \\
1,285,856\end{array}$ & $\begin{array}{r}0 \\
1,658,019\end{array}$ & $\begin{array}{r}0 \\
1,604,534\end{array}$ & $\begin{array}{r}0 \\
1658019\end{array}$ & $\begin{array}{r}0 \\
1.604 .534\end{array}$ & $\begin{array}{r}6 \\
658019\end{array}$ & $.775,281$ \\
\hline Total CHP Plant Generation (kWh) & & $1,658,019$ & $1,125,403$ & $1,658,019$ & $1,604,534$ & $\frac{1,658,019}{1,650}$ & $1,602,306$ & $1,285,856$ & $1,658,019$ & $1,604,534$ & $\frac{1,658,019}{1,658,019}$ & $1,604,534$ & 1,658,019 & $18,775,281$ \\
\hline Total Energy Sales & & & & & & & & & & & & & & \\
\hline $\begin{array}{l}\text { AMPAC Energy Sales }(\mathrm{kWh}) \\
\text { SMUD Grid Energy Sales }(\mathrm{kWh})\end{array}$ & & $\begin{array}{r}1,480,334 \\
177,684\end{array}$ & $\begin{array}{r}1,010,890 \\
114,512\end{array}$ & $\begin{array}{r}1,527,975 \\
130,044\end{array}$ & $\begin{array}{r}1,478,289 \\
126,246\end{array}$ & $\begin{array}{l}1,599,293 \\
58,726\end{array}$ & $\begin{array}{l}1,509,468 \\
92,838\end{array}$ & $\begin{array}{r}1,265,885 \\
19,971\end{array}$ & $\begin{array}{r}1,635,823 \\
22,196\end{array}$ & $\begin{array}{r}1,592,940 \\
11,595\end{array}$ & $\begin{array}{r}1,573,3635 \\
8,384\end{array}$ & $\begin{array}{r}1,472,015 \\
126,520\end{array}$ & $\begin{array}{r}1,468,3944 \\
119,625\end{array}$ & $\begin{array}{r}17,620,941 \\
1,154,340\end{array}$ \\
\hline Total CHP Plant Generation (kWh) & & $1,658,019$ & $1,125,403$ & $\begin{array}{ll}1,658,019 \\
\end{array}$ & $1,604,534$ & $1,658,019$ & $1,602,306$ & $1,285,856$ & $1,658,019$ & $1,604,534$ & $1,658,019$ & $1,604,534$ & \begin{tabular}{|c|}
$1,658,019$ \\
\end{tabular} & 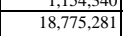 \\
\hline GPAC Energ & & & & & & & & & & & & & & \\
\hline per Pea & & 0 & 0 & 0 & 0 & & 401,134 & 320,907 & 414,505 & 401,134 & 0 & 0 & & $1,537,679$ \\
\hline On Peak Energy Sales (kWh) & & 690,841 & 467,989 & 690,841 & 668,556 & 690,841 & 267,422 & \begin{tabular}{|l|l|}
213,938 \\
\end{tabular} & 276,336 & 267,422 & 690,841 & 668,556 & 690,841 & $6,284,426$ \\
\hline Off Peak Energy Sales (kWh) & & 789,493 & 542,901 & 837,133 & 809,733 & 908,452 & 840,912 & 731,041 & 944,982 & 924,384 & 882,794 & 809,459 & 777,553 & $9,798,835$ \\
\hline $\begin{array}{l}\text { AMPAC Energy Sales (kWh) } \\
\text { (k) }\end{array}$ & & $1,480,334$ & $1,010,890$ & $1,527,975$ & $1,478,289$ & $1,599,293$ & $\begin{array}{ll}, 509,468 \\
\end{array}$ & $1,265,885$ & $1,635,823$ & $\begin{array}{l}1,592,940 \\
\end{array}$ & 1,573,635 & $1,478,015$ & $\begin{array}{l}1,468,394 \\
\end{array}$ & $\frac{17,620,941}{17,621}$ \\
\hline & & & & & & & & & & & & & & \\
\hline per & $\$$ & $-s$ & & $-s$ & & $\$$ & $0.1203 \$$ & $0.1203 \$$ & 0.1203 & \begin{tabular}{l|l}
0.1203 & $\$$
\end{tabular} & 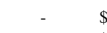 & 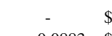 & & 0.1204 \\
\hline in Peak & $\$$ & $0.0883 \mathrm{~s}$ & $0.0883 \$$ & $0.0883 \mathrm{~s}$ & $0.0883 \mathrm{~s}$ & $0.0883 \$$ & $0.1057 \$$ & $0.1057 \$$ & $0.1057 \mathrm{~s}$ & 0.1057 \$ & 0.0883 & $0.0883 \mathrm{~s}$ & 0.0883 & 0.0911 \\
\hline fff Peak Energy Rate ( $\$ / k W h)$ & $\$$ & $0.0699 \mathrm{~s}$ & $0.0699 \$$ & $0.0699 \mathrm{~s}-\mathrm{r}-\mathrm{s}$ & $0.0699 \mathrm{~s}$ & $0.0699 \$$ & $0.0863 \$$ & $0.0863 \$$ & $0.0863 s$ & $0.0863 \$$ & $0.0699 \mathrm{~s}$ & $0.0699 \$$ & 0.0699 & 0.0757 \\
\hline AMPAC & & & & & & & & & & & & & & \\
\hline Super $\mathrm{F}$ & $\$$ & -s & & $-s$ & & $-\$$ & $\begin{array}{ll}48,300 \quad \$ \\
39200 & \$\end{array}$ & $\begin{array}{ll}38,600 \quad \mathrm{~s} \\
3,600 & \mathrm{~s}\end{array}$ & $49,900 \mathrm{~s}$ & $48,300 \$$ & $-s$ & -9 & & $\begin{array}{r}185,100 \\
\end{array}$ \\
\hline On Peak Energy Revenues (\$) & $\$$ & $61,000 \$$ & $41,300 \$$ & $\begin{array}{ll}61,000 \\
58500\end{array}$ & $59,000 \mathrm{~s}$ & $61,000 \$$ & " & $22,600 \$$ & 29,200 & $28,300 \$$ & $61,000 \$$ & $59,000 \$$ & 61,000 & 572,700 \\
\hline Off Peak Energy Revenues (\$) & $\frac{\$}{s}$ & $\begin{array}{rl}55,200 \mathrm{~s} \\
116200 & \mathrm{~s}\end{array}$ & $\begin{array}{l}37,900 \$ \$ \\
7920-\$\end{array}$ & $\begin{array}{r}58,500 \mathrm{~s} \\
119500\end{array}$ & $56,600 \mathrm{~s}$ & $63,500 \$$ & $72,600 \$$ & $63,100 \$$ & 81,600 & $79,800 \$$ & $\begin{aligned} 61,700 \mathrm{~s} \\
\end{aligned}$ & $\begin{aligned} 56,600 & \$ \\
115600 & \$\end{aligned}$ & $\begin{array}{r}54,400 \\
11500\end{array}$ & 741,500 \\
\hline AMPAC Energy Revenues (\$) & & $116,200 \mathrm{~s}$ & $79,200 \$$ & $119,500 \mathrm{~s}$ & $115,600 \mathrm{~s}$ & $124,500 \$$ & 149,200 \$ & $124,300 \mathrm{~S}$ & 160,700 & $156,400 \$$ & $122,700 \mathrm{~s}$ & $115,600 \mathrm{~s}$ & 115,400 & $\$ \quad 1,499,300$ \\
\hline IUD & & & & & & & & & & & & & & \\
\hline & & & & & & & $\frac{0}{2605}$ & 0 & & & 0 & & & 33035 \\
\hline Off Peak & & $\begin{array}{r}49,675 \\
12,009\end{array}$ & $\begin{array}{l}32,599 \\
88,1924\end{array}$ & $\begin{array}{l}\begin{array}{l}37,755 \\
92,289\end{array} \\
\end{array}$ & $\begin{array}{l}36,471 \\
89,775\end{array}$ & $\begin{array}{l}16,418 \\
42,308\end{array}$ & $\begin{array}{l}26,895 \\
65,943\end{array}$ & $\begin{array}{r}5,805 \\
14,166\end{array}$ & $\begin{array}{r}6,205 \\
15,990\end{array}$ & $\begin{array}{l}3,350 \\
8,245\end{array}$ & $\begin{array}{l}23,591 \\
60,793\end{array}$ & $\begin{array}{l}36,550 \\
89970\end{array}$ & $\begin{array}{r}55,052 \\
134,53\end{array}$ & $\begin{array}{l}330,355 \\
823,985\end{array}$ \\
\hline SMUD Grid Energy Sales (kWh) & & 177,684 & 114,512 & 130,044 & 126,246 & 58,726 & 92,838 & 19,971 & 22,196 & $\frac{0,45}{11,595}$ & 84,384 & $\frac{0,36,50}{12620}$ & 189,625 & $1,154,340$ \\
\hline SMUD - 1 & & & & & & & & & & & & & & \\
\hline Super $\mathrm{Y}$ & $\$$ & $0.0606 \mathrm{~s}$ & $0.0606 \$$ & $505 s$ & $0.0505 \mathrm{~s}$ & $5 0 5 \longdiv { \$ }$ & $0.2235 \$$ & $0.2235 \$$ & $0.2235 \mathrm{~s}$ & $0.2235 \$$ & 0.0606 & $0.0606 \$$ & 0.0606 & $\$$ \\
\hline . & $\$$ & $0.0551 \mathrm{~s}$ & $0.0551 \$$ & $186 s$ & $0.0486 \mathrm{~s}$ & $3486 \$$ & $0.0583 \$$ & $0.0583 \$$ & $0.0583 \mathrm{~s}$ & $0.0583 \$$ & 0.0551 & $51 \$$ & 0.0551 & 0.0536 \\
\hline Off Peak Energy Rate ( $\$(k W h)$ & $\$$ & $0.0433 \$$ & $0.0433 \$$ & $0.0374 \mathrm{~s}$ & $0.0374 \mathrm{~s}$ & $0.0374 \$$ & $0.0499 \$$ & $0.0499 \$$ & 0.0499 & $0.0499 \$$ & $0.0433 \mathrm{~s}$ & $0.0433 \$$ & 0.0433 & 0.0426 \\
\hline & & & & & & & & & & & & & & \\
\hline & $\$$ & $-s$ & & $s$ & & $\$$ & & -5 & $s$ & - & $-s$ & $\$$ & & \\
\hline On Pea & $\$$ & $2,700 \mathrm{~s}$ & $1,800 \$$ & $1,800 \leqq$ & $1,800 \mathrm{~s}$ & $00 \$$ & $1,600 \$$ & $300 \mathrm{~s}$ & 400 & $200 \$$ & $1,300 \$$ & $2,000 \$$ & 3,000 & 17,700 \\
\hline Off Peak & $\$$ & $5,500 \mathrm{~s}$ & $3,600 \$$ & $3,500 \mathrm{~s}$ & $3,400 \mathrm{~s}$ & $1,600 \$$ & $3,300 \$$ & $700 \mathrm{~s}$ & $800 \mathrm{~s}$ & $400 \$$ & $2,600 \mathrm{~s}$ & $3,900 \$$ & 5,800 & 35,100 \\
\hline $\begin{array}{l}\text { SMUD Grid Energy Revenues (\$) } \\
\text { (a) }\end{array}$ & $\$$ & $8,200 \mathrm{~s}$ & $5,400 \$$ & $5,300 \mathrm{~s}$ & $5,200 \mathrm{~s}$ & $2,400 \$$ & 4,900 \$ & $1,000 \mathrm{~s}$ & $1,200 \mathrm{~s}$ & $600 \$$ & $3,900 \$$ & $5,900 \$$ & 8,800 & 52,800 \\
\hline & & & & & & & & & & & & & & \\
\hline & $\$$ & $116,200 \mathrm{~s}$ & $79,200 \$$ & $119,500 \mathrm{~s}$ & $115,600 \mathrm{~s}$ & $124,500 \$$ & 149,200 & 124,300 & 160,700 & 156,400 & $122,700 \mathrm{~s}$ & $115,600 \quad \$$ & 115,400 & $1,499,300$ \\
\hline $\mathrm{DC}$ & $\$$ & $8,200 \$$ & $5,400 \quad \$$ & 5,300 & $5,200 \quad \mathrm{~S}$ & $2,400 \$$ & 4,900 & 1,000 & 1,200 & 600 & $3,900 \$$ & $5,900 \$$ & 8,800 & 52,800 \\
\hline otal Energy Revenues (\$) & $\$$ & $124,400 \mathrm{~s}$ & 84,600 \$ & $124,800 \mathrm{~S}$ & $120,800 \mathrm{~S}$ & 126,900 \$ & $154,100 \$$ & $125,300 \quad \$$ & $161,900 \mathrm{~s}$ & 157,000 \$ & $126,600 \mathrm{~s}$ & $121,500 \mathrm{~s}$ & \begin{tabular}{ll|l}
124,200 \\
\end{tabular} & $\begin{array}{|ll|}\$ & 1,552,100 \\
\end{array}$ \\
\hline
\end{tabular}




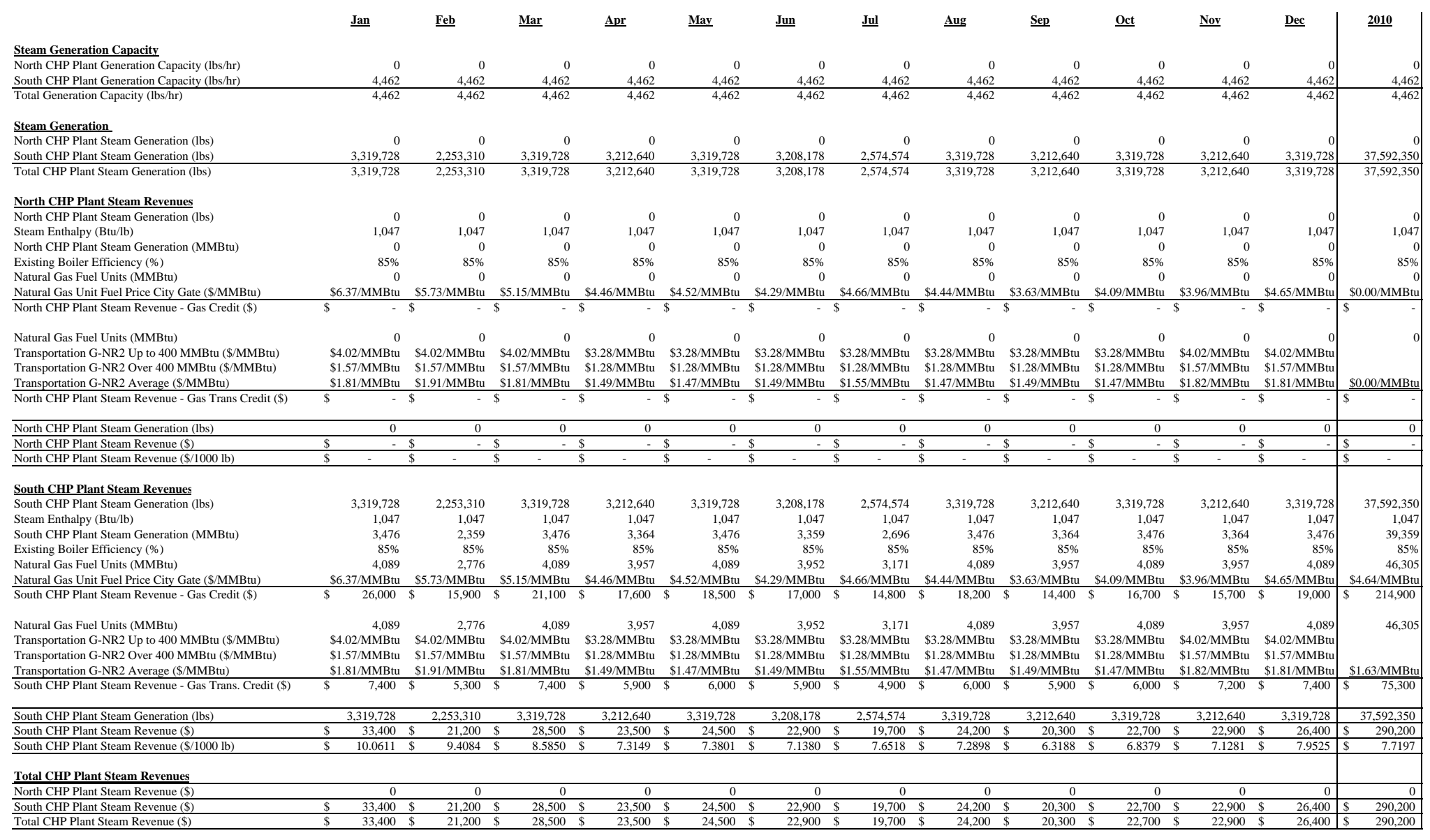




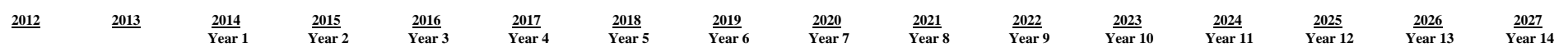

Steam Generation Capacity

South CHP Plant Generation Capacity (lbs/

\begin{tabular}{rr}
0 & 0 \\
4,462 & 4,462 \\
\hline 4,462 & 4,462
\end{tabular}

0
4,462
4,462 0
4,462
4,62

$\begin{array}{r}0 \\ 4,462 \\ \hline 4,462\end{array}$ 0
4,462
4,462 0
4,462
4,462 $\begin{array}{r}0 \\ 4,462 \\ \hline 4,462\end{array}$ 0
4,462
4,462 0
4,462
4,462 $\begin{array}{r}0 \\ 4,462 \\ \hline 4,462\end{array}$ 0
4,462
4,462 0
4,462
4,462 \begin{tabular}{rrr}
0 & 0 & 0 \\
4,462 & 4,462 & 4,462 \\
\hline 4,462 & 4,462 & 4,462
\end{tabular}

North CHP Plant Steam Generation (lbs) South CHP Plant Steam Generation (lbs)

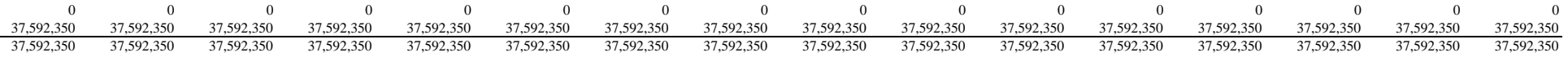
$\frac{\text { North CHP Plant Steam Revenues }}{\text { North CHP Plant Steam Generation (lbs) }}$ Steam Enthalpy (Btu/lb) eneration (MMBtu) Existing Boiler Efficiency (\%)

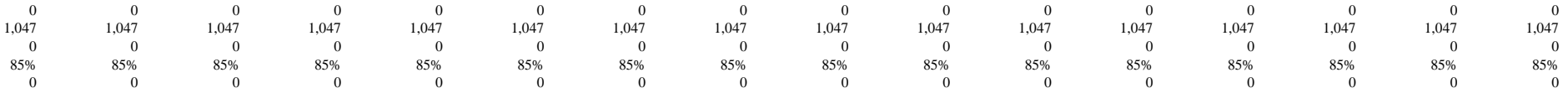
Natural Gas Unit Fuel Price City Gate (S/MMBtu)

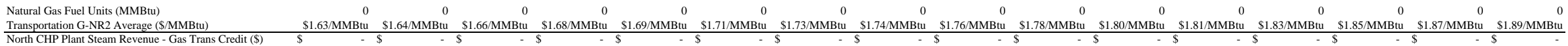

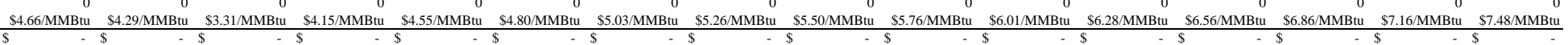

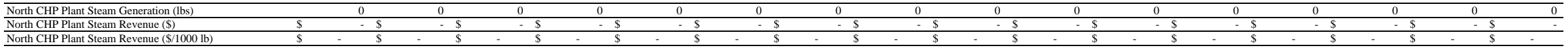

\section{South CHP Plant Steam Revenues} Steam Enthalpy (Btu/b)

ation (MMBtu) Natural Gas Fuel Units (MMBtu) Natural Gas Unit Fuel Price City Gate (S/MMBtu)

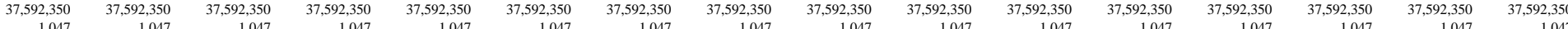

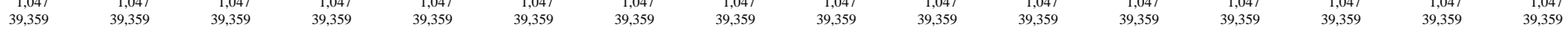

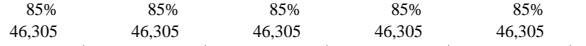

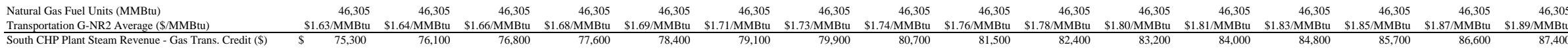
\begin{tabular}{crc}
\hline $6 / \mathrm{MMBtu}$ & $\$ 4.29 / \mathrm{MMBtu}$ & $\$ 3.3$ \\
214,900 & 198,500
\end{tabular}

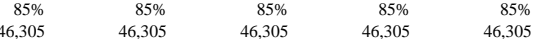
$\begin{array}{lrr}85 \% & 39,359 & 39,35 \% \\ 85 \% & 85 \%\end{array}$ \begin{tabular}{rrr}
46,305 & 46,305 & $85 \%$ \\
\hline
\end{tabular} $\begin{array}{rrr}85 \% & 39,359 & 39,35 \\ 85 \% & 85 \%\end{array}$ $46,305 \quad 46,305$ \begin{tabular}{rr}
46,305 & 46,305 \\
MMBtu & $\$ 7.48 / \mathrm{MMB}$ \\
\hline
\end{tabular}

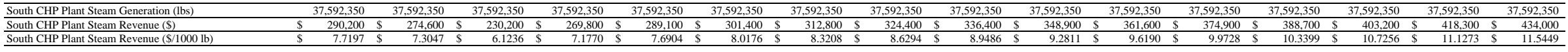

Total CHP Plant Steam Revenues

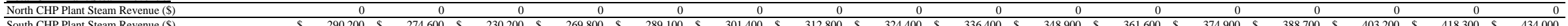
South CHP Plant Steam Revenue (S)

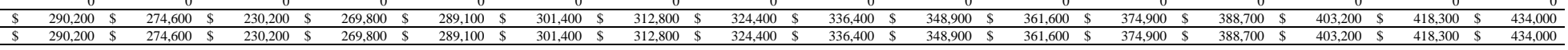


6.0a ANNUAL WASTE DISPOSAL REVENUES

Total CHP Plant Waste Disposal Revenues [1]

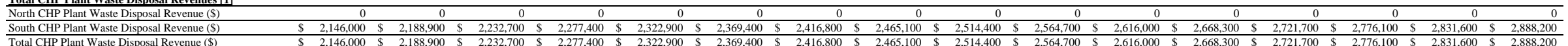

[1] Estimated to be $\$ 2,146,000$ annually, inflatted at $2.0 \%$ per year 


\begin{tabular}{|c|c|c|c|c|c|c|c|c|c|c|c|c|c|}
\hline & $\underline{\text { Jan }}$ & $\underline{\text { Feb }}$ & $\underline{\text { Mar }}$ & Apr & $\underline{\text { May }}$ & $\underline{\mathrm{Jun}}$ & $\underline{\mathrm{Jul}}$ & $\underline{\text { Aug }}$ & $\underline{\text { Sep }}$ & $\underline{\text { Oct }}$ & $\underline{\text { Nov }}$ & $\underline{\text { Dec }}$ & $\underline{2012}$ \\
\hline$\frac{\text { Electric Generation Capaci }}{\text { North CHP Plant Generation }}$ & & & & & & & & & & & & & \\
\hline $\begin{array}{l}\text { North CHP } \\
\text { South CHP }\end{array}$ & 2,229 & $\begin{array}{r}0 \\
2,229\end{array}$ & $\begin{array}{r}0 \\
2,229\end{array}$ & 2,229 & $\begin{array}{r}0 \\
2,229\end{array}$ & $\begin{array}{r}0 \\
2,229\end{array}$ & $\begin{array}{r}0 \\
2,229\end{array}$ & $\begin{array}{r}0 \\
2,229\end{array}$ & $\begin{array}{r}0 \\
2,229\end{array}$ & $\begin{array}{r}0 \\
2,229\end{array}$ & 2,229 & $\begin{array}{r}0.229 \\
0\end{array}$ & \\
\hline Total Generation Capacity $(\mathrm{kW})$ & 2,229 & 2,229 & 2,229 & 2,229 & 2,229 & $\frac{2,259}{2,229}$ & 2,229 & 2,229 & 2,229 & 2,229 & 2,229 & 2,229 & \\
\hline \multicolumn{14}{|l|}{ Electric Generation Energy } \\
\hline $\begin{array}{l}\text { North CHP Plant Generation (kWh) } \\
\text { South }\end{array}$ & 0 & & 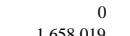 & $\begin{array}{r}0 \\
1604534\end{array}$ & 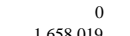 & 0 & 0 & 0 & & $\begin{array}{r}0 \\
5809\end{array}$ & 0 & & \\
\hline $\begin{array}{l}\text { South CHP Plant Generation }(\mathrm{kWh}) \\
\text { Total CHP Plant Generation }(\mathrm{kWh})\end{array}$ & $\frac{1,658,019}{1,658,019}$ & $\begin{array}{l}1,125,403 \\
1,125,403\end{array}$ & $1,658,019$ & $\frac{1,604,534}{1,604,534}$ & $\frac{1,658,019}{1,658,019}$ & $\frac{1,602,306}{1,602,306}$ & $\frac{1,285,856}{1,285,856}$ & $\frac{1,658,019}{1,658,019}$ & $\frac{1,604,534}{1,604,534}$ & $\frac{1,658,019}{1,658,019}$ & $\begin{array}{l}1,604,534 \\
1,604,534\end{array}$ & $\frac{1,658,019}{1,658,019}$ & 3,775: \\
\hline \multicolumn{14}{|l|}{ North CHP Plant Production Costs } \\
\hline $\begin{array}{l}\text { North CHP Plant Generation Capacity } \\
\text { Nort }\end{array}$ & 0 & 0 & 0 & 0 & 0 & 0 & 0 & 0 & 0 & 0 & 0 & & \\
\hline North $\mathrm{CH}$ & 0 & 0 & 0 & 0 & 0 & 0 & 0 & 0 & 0 & 0 & 0 & & \\
\hline North CHP Plant Heat Rate HF & 0 & 0 & 0 & 0 & 0 & 0 & 0 & 0 & 0 & 0 & 0 & & \\
\hline North CHP Plant Fuel Use HHV (MMBtu) & & & & & & & & 0 & 0 & 0 & 0 & & \\
\hline $\begin{array}{l}\text { Natural Gas Unit Fuel Price City Gate (\$/MMBtu) } \\
\text { North CHP Plant Natural Gas Fuel Cost (\$) }\end{array}$ & $\frac{\text { MMBtu }}{-\$}$ & $\frac{\text { Btu }}{--s}$ & & Btu & Btu & & & & & & & & \\
\hline $\begin{array}{l}\text { North CHP Plant Fuel Use HHV (MMBtu) } \\
\text { Transportation G-EG (SMMBtu) }\end{array}$ & $\begin{array}{r}0 \\
\text { \$0.31/MMBtu } \\
\end{array}$ & $\begin{array}{r}0 \\
\text { \$0.31/MMBtu }\end{array}$ & $\begin{array}{r}0 \\
\text { \$0.31/MMBtu }\end{array}$ & $\begin{array}{c}0 \\
\text { S0.31/MMBtu }\end{array}$ & $\begin{array}{r}0 \\
\$ 0.31 / \mathrm{MMBtu}\end{array}$ & $\begin{array}{r}0 \\
\text { \$0.31/MMBtu }\end{array}$ & $\begin{array}{r}0 \\
\text { S0.31/MMBtu }\end{array}$ & $\begin{array}{r}0 \\
\text { \$0.31/MMBtu }\end{array}$ & $\begin{array}{r}0 \\
31 / \mathrm{MMBtu}\end{array}$ & $\begin{array}{r}0 \\
\text { S0.31/MMBtu }\end{array}$ & $\begin{array}{rl}0 & 0 \\
31 / \text { MMBtu } & -1\end{array}$ & IBtul & \\
\hline$\frac{1 \text { North CHP Plant Natural Gas Transportation Cost (\$) }}{\text { Nos }}$ & $\$-\$$ & & & & & & & & & & & & \\
\hline Total N & 0 & 0 & 0 & 0 & 0 & 0 & 0 & 0 & 0 & 0 & 0 & & \\
\hline \begin{tabular}{|l} 
Total North CHP Plant Natural Gas Fuel Cost (\$) \\
Total North CHP Plant Natural Gas Fuel Cost (S/MMBtu) \\
\end{tabular} & -5 & - & $-\$$ & $-\$$ & $-\$$ & $-\$$ & $-\$$ & $-\$$ & & - & & & $\$$ \\
\hline \multicolumn{14}{|l|}{$\underline{\text { South CHP Plant Production Costs }}$} \\
\hline South $\mathrm{C}$ & 2,229 & 2,229 & 2,229 & 2,229 & 2,229 & 2,229 & 2,229 & 2,229 & 2,229 & 2,229 & 2,229 & 2,229 & \\
\hline South CF & $1,658,019$ & $1,125,403$ & $1,658,019$ & $1,604,534$ & $1,658,019$ & $1,602,306$ & $1,285,856$ & $1,658,019$ & $1,604,534$ & $1,658,019$ & $1,604,534$ & $1,658,019$ & 18,775 \\
\hline South C & 9,651 & 9,651 & 9,651 & 9,651 & 9,651 & 9,651 & 9,651 & 9,651 & 9,651 & 9,651 & 9,651 & 9,651 & \\
\hline & 16,001 & 10,861 & 16,001 & 15,485 & 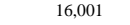 & 15,464 & 12,410 & 16,001 & 15,485 & & 15,485 & & \\
\hline Maximum Waste to Fuel Nat & $\underline{12,648}$ & $\underline{11,424}$ & 12,648 & $\underline{12,240}$ & 12,648 & 12,240 & $\underline{12,648}$ & 12,648 & 12,240 & 12,648 & 12,240 & 12,648 & \\
\hline NET South CHP Plant Fuel Use HHV (MMBtu) & 3,353 & & 3,353 & 3,245 & 3,353 & 3,224 & & $\frac{1,3,353}{3,353}$ & $\frac{1,245}{3,245}$ & $\frac{1,3,35}{3,353}$ & $\frac{1,2,245}{3,245}$ & $\frac{1,3,353}{3,353}$ & \\
\hline Natural Gas Unit Fuel Price City Gate & \$6.37/MMBtu & uMBtu & 5/MMBtu & MMBtu $\$$ & $\$ 4.52 / \mathrm{MMBtu}$ & $\$ 4.29 / \mathrm{MMBtu} \$$ & MMBtu & $\$ 4.44 / \mathrm{MMBtu} \$$ & $\$ 3.63 / \mathrm{MMBtu} \quad \$$ & $\$ 4.09 / \mathrm{MMBtu}$ & $\$ 3.96 / \mathrm{MMBtu}$ & & $\$ 4.57 / \mathrm{MN}$ \\
\hline $\begin{array}{l}\text { South CHP Plant Natural Gas Fuel Cost (\$) } \\
\end{array}$ & $21,400 \$$ & st & $17,300 \$$ & 14,500 \$ & $15,200 \$$ & $13,800 \$$ & & $14,900 \$$ & 11,800 \$ & $13,700 \$$ & $12,900 \$$ & 15,600 & \\
\hline South CHP Plant Fuel Use HHV (MMBtu) & 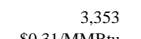 & 0 & 3,353 & 3,245 & 3,353 & 3,224 & 0 & 3,353 & 3,245 & 3,353 & 3,245 & & \\
\hline $\begin{array}{l}\text { Transportation G-EG (S/MMBtu) } \\
\text { South CHP Plant Natural Gas Transportation Cost (\$) }\end{array}$ & $\begin{array}{l}\text { \$0.31/MMBtu } \\
\$ \$ 1,000 \$\end{array}$ & & $\begin{array}{lll}\$ 0.31 / \text { MMBtu } \\
\$ 1,000 \quad \$\end{array}$ & $\begin{aligned} & \$ 0.31 / \text { MMBtu } \$ \\
& 1,000 \quad \$\end{aligned}$ & $\begin{array}{l}\$ 0.31 / \mathrm{MMBtu} \quad \\
\$ 1,000 \quad \$\end{array}$ & $\begin{array}{l}\text { /MMBtu } \$ \\
1,000 \quad \$\end{array}$ & $\frac{\text { MBtu }}{-\$}$ & $\begin{array}{l}\text { MMBtu } \\
1,000 \$\end{array}$ & $\begin{array}{ll}\text { MMBtu } \$ \\
1,000 \quad \$\end{array}$ & $\frac{\text { MMBtu }}{1,000 \$}$ & $\frac{31 / \mathrm{MMBtu}}{1,000 \$}$ & MMBtu| & $\frac{M M}{10,0}$ \\
\hline IP Plant Natural Ga & 3,3 & 0 & 3,353 & 3,245 & 3,353 & 3,224 & 0 & 3,353 & 3,245 & 3,353 & 3,245 & 3,353 & \\
\hline Total South CHP Plant Natural Gas Fuel Cost (\$) & $\begin{array}{lrl} & 22,400 \quad \$ \\
\end{array}$ & & $\$ \quad 18,300 \$$ & $15,500 \$$ & $16,200 \$$ & $\begin{array}{lr}\$ \quad 14,800 \quad \$ \\
\end{array}$ & -5 & \begin{tabular}{|lrl}
$\$$ & $15,900 \quad \$$ \\
\end{tabular} & $12,800 \quad \$$ & $14,700 \mathrm{~S}$ & $\begin{array}{lrl}\$ & 13,900 \quad \$ \\
\end{array}$ & $\begin{array}{rr}\$ 16,600 \\
\end{array}$ & $\$$ \\
\hline Total South CHP Plant Natural Gas Fuel Cost (\$/MMBtu) & \$6.68/MMBtu & & \$5.46/MMBtu & \$4.78/MMBtu \$ & $\$ 4.83 / \mathrm{MMBtu}$ & \$4.59/MMBtu & & .74/MMBtu $\mathrm{s}$ & $\$ 3.94 / \mathrm{MMBtu}$ & \$4.38/MMBtu & $\$ 4.28 /$ MMBtu & \$4.95/MMBtu & $\$ 4$. \\
\hline \multicolumn{14}{|c|}{3.245} \\
\hline Total Nat & , & 0 & 3,353 & 3,245 & 3,353 & 3,224 & 0 & 3,353 & 3,245 & 3,353 & 3,245 & 853 & \\
\hline Total Natu & 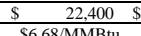 & & $18,300 \$$ & $15,500 \$$ & $16,200 \$$ & $14,800 \$$ & & $15,900 \$$ & $\frac{12,800 \$}{\$}$ & $14,700 \$$ & $13,900 \quad \$$ & 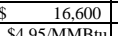 & $\$$ \\
\hline
\end{tabular}




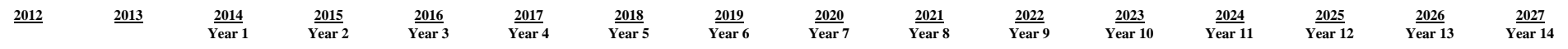

Electric Generation Capacity

South CHP Plant Generation Capacity (kW)

Total Generation Capacity $(\mathrm{kW})$

$\begin{array}{rr}0 & 0 \\ 2,229 & 2,229 \\ 2,229 & 2,229\end{array}$

0
2,229
2,229

0
2,229
2,229

0
2,229
2,229

Electric Generation Energy

$\frac{\text { South CHP Plant Generation }(\mathrm{kWh})}{\text { Total CHP Plant Generation }(\mathrm{WWh})}$

\begin{tabular}{rrrrrrrrrrrrrrrrr}
0 & 0 & 0 & 0 & 0 & 0 & 0 & 0 & 0 & 0 & 0 & 0 \\
$18,775,281$ & $18,775,281$ & $18,775,281$ & $18,775,281$ & $18,775,281$ & $18,755,281$ & $18,775,281$ & $18,775,281$ & $18,775,281$ & $18,755,281$ & $18,775,281$ & $18,775,281$ & $18,775,281$ & $18,775,281$ & $18,775,281$ & $18,775,281$ \\
\hline $18,775,281$ & $18,775,281$ & $18,775,281$ & $18,775,281$ & $18,775,281$ & $18,775,281$ & $18,775,281$ & $18,775,281$ & $18,775,281$ & $18,775,281$ & $18,775,281$ & $18,775,281$ & $18,775,281$ & $18,775,281$ & $18,775,281$ & $18,775,281$
\end{tabular}

\section{North CHP Plant Production Costs}

North CHP Plant Generation Capacity $(\mathrm{kW})$

North CHP Plant Generation $(\mathrm{kWh})$
North CHP Plant Heat Rate HHV

North CHP Plant Fuel Use HHV (MMBtu)

$\frac{\text { Natural Gas Unit Fuel Price City Gate (S/MMBt }}{\text { North CHP Plant Natural Gas Fual }}$

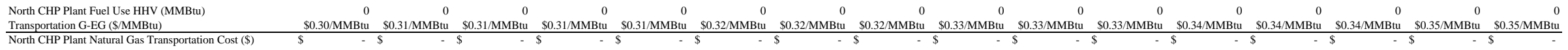

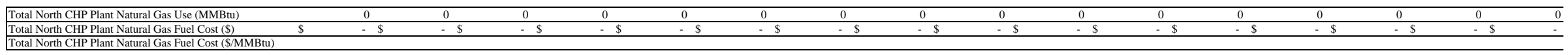

South CHP Plant Production Costs

t Generation Capacity $(\mathrm{kW})$

South CHP Plant Generation (kWh)
South CHP Plant Heat Rate HHV (Btu/kWh)

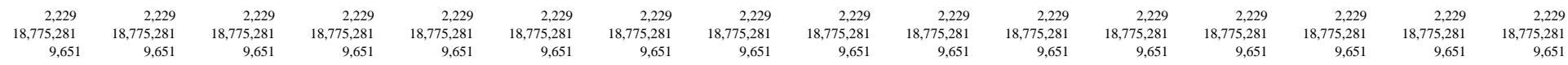

South CHP Plant Fuel Use HHV (MMBtu)

$\frac{\text { Natural Gas Unit Fuel Price City Gate (\$/MMBtu) }}{\text { South CHP Plant Natural Gas Fuel Cost (\$) }}$

$\begin{array}{lllll}33,079 & 33,079 & 33,079 & 33,079 & 33,079\end{array}$

$33,079 \quad 33,079 \quad 33,079$

$33,079 \quad 33,079$

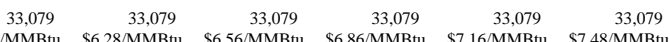

Suth CHP Plant Fuel Use HHV (MMBtu)

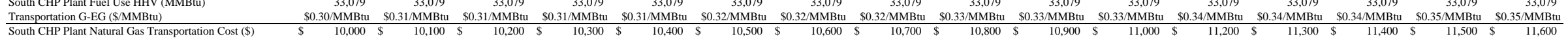

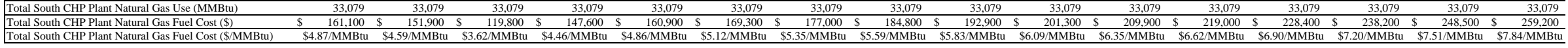

\section{Total CHP Plant Production Costs}

Total Natural Gas Fuel Use (MMB

Total Natural Gas Fuel Cost (\$)

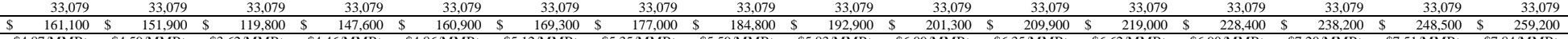

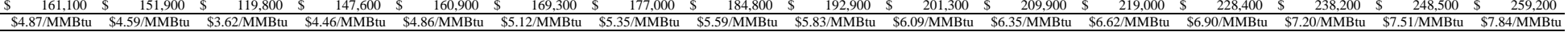




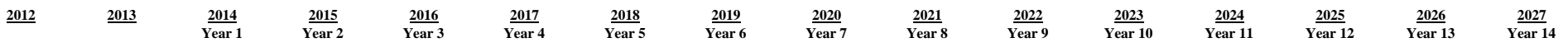
Incremental Labor Costs

\section{Management (Qty)}

Burdened Hourly Rate (Shr)

Escalation (\%)

000

Additional Operators (Qty)
Burdened Hourly Rate (\$hr)

Burdened Hourly Rate (\$hr)
Escalation (\%)

\begin{tabular}{|c|c|c|}
\hline $\begin{array}{c}0 \\
100.00 \\
2.00 \%\end{array}$ & $\begin{array}{c}0 \\
102.00 \\
2.00 \%\end{array}$ & $\begin{array}{r}0 \\
104.04 \\
2.00 \%\end{array}$ \\
\hline
\end{tabular}

$\begin{array}{rrr}0 & 0 \\ 50.00 & \$ & 51.00 \$\end{array}$

Escalation (\%)

Additional Maintenance Techs (Qty)
Burdened Hourly Rate (Shr) Burdened Hourly Rate (\$hr)
Escalation (\%)
Maintenanne Techs Labor Cost (\$)

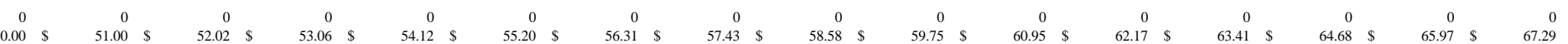

Total Additional Labor Cost (\$)

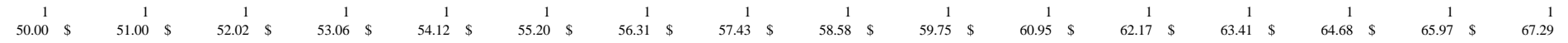

North Plant CHP Maintenance Cos

Number of Units
Prime Mover Maintenance Cost (\$/unit)

$\frac{\text { Escalation (\%) }}{\text { Total Prime Mover Maintenance Cost (\$) }}$

\section{South Plant CHP Maintenance Cost}

Noumber of Units

Escalation (\%)
Total Prime Mover Maintenance Cost $(\$)$

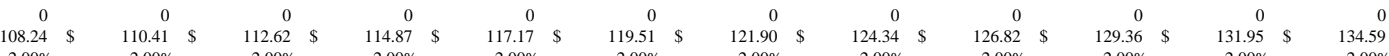

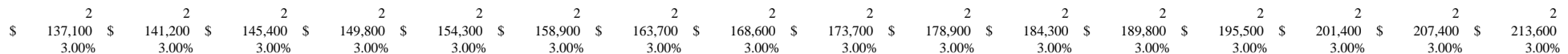
Total Additional Maintenance Cost (\$)

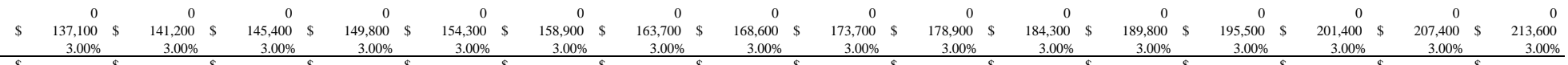

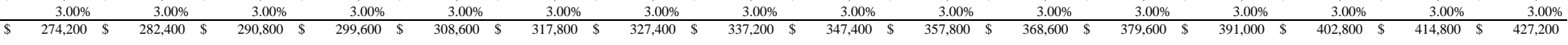

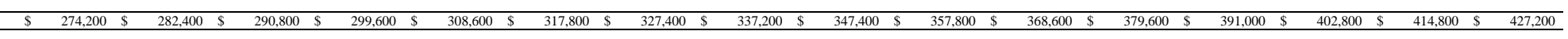


$\frac{\text { Financing Assumptions }}{\text { Debt Term (years) }}$

Debt Term (years)
Interest Rate

Investment Tax Credit
Capital Cost

Less SGIP Incentive
Less Tax Credit

Financed Amount

Debt Financed

Equity Financed
Total Debt Financing

Long Term Financing

Interest Rate
Amount to Finan

Beginning Year Balance

Interest
Principal

Annual Debt Payment

End of Year Balance $\underline{2012}$

$\underline{2013}$

$\frac{2014}{\text { Year } 1} \quad \frac{2015}{Y}$

$\frac{2015}{\text { Year } 2}$

$\frac{2016}{\text { Year }}$

$\underline{2017}$

$\frac{2018}{\operatorname{Year} 5}$

$\frac{2019}{\text { Year }}$

Year

$\frac{2021}{\text { Year } 8} \quad \frac{202}{\text { Year }}$

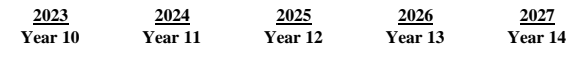

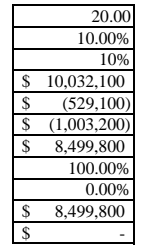

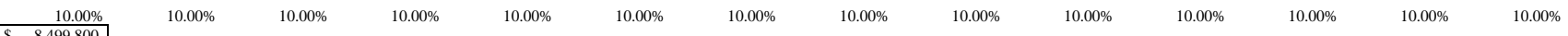

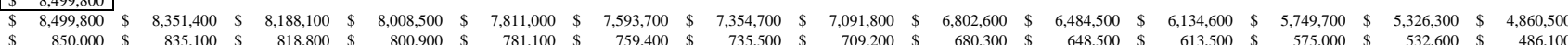

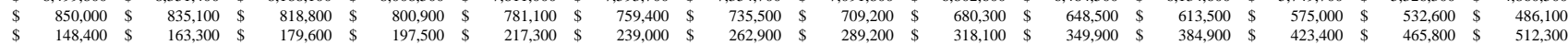

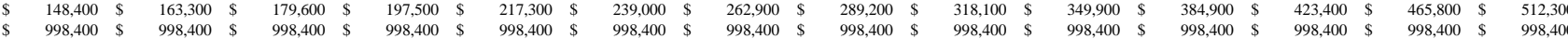

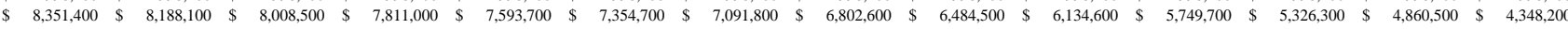


10.0 DEPRECIATION

Capital Cost
Less SGIP Incentive

Less SGIP Incentive
Less Tax Credit

Depreciable Basis [1]
Depreciation Method

Depreciation Percentage
Depreciation Expense

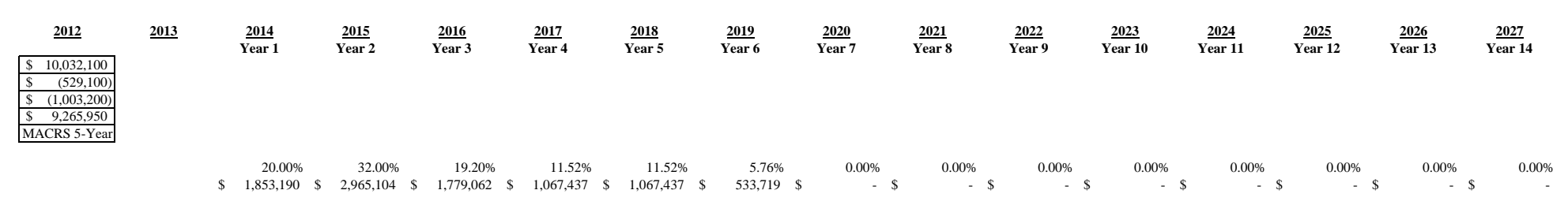

[1] Depreciable Basis is equal to total project cost less the tax credits and rebate for which the project qualifies. 


\subsection{PRO FORMA}

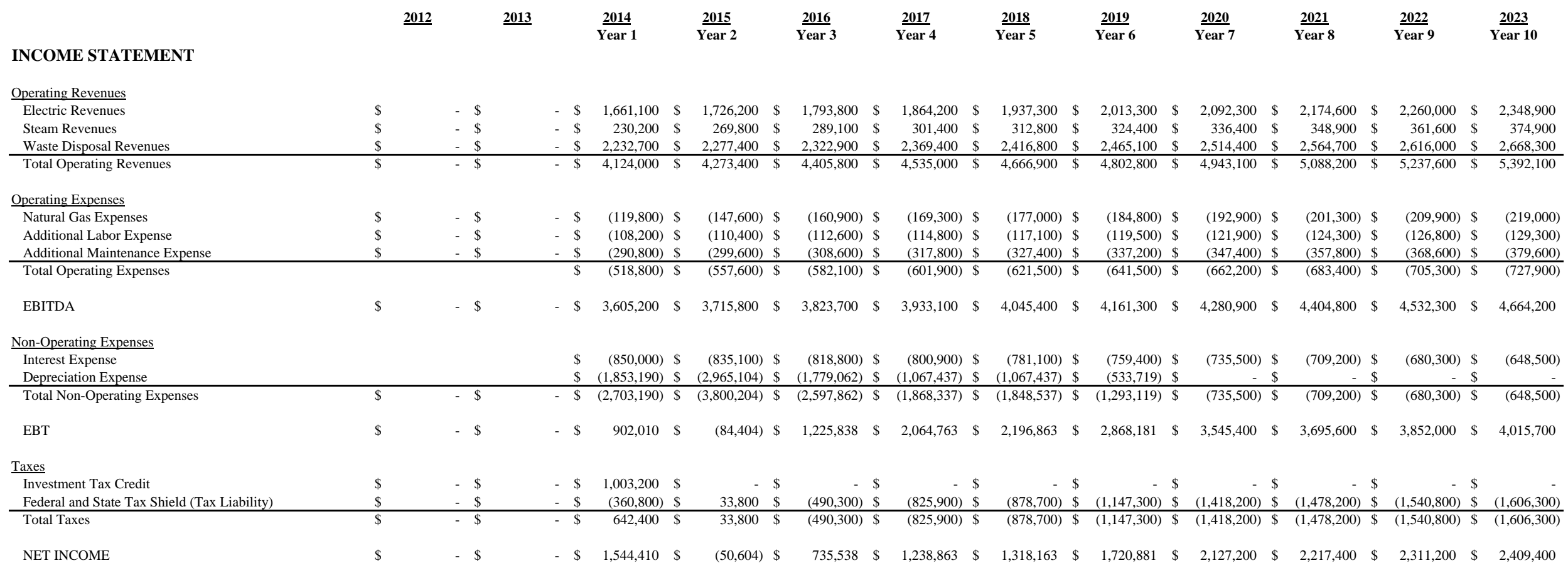

\section{CASH FLOW STATEMENT}

Cash Flows Operating Activitie

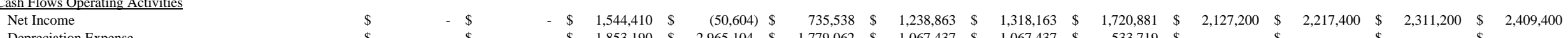
\begin{tabular}{l} 
Depreciation Expense \\
\hline Net Cash Flows Operating Activities
\end{tabular}

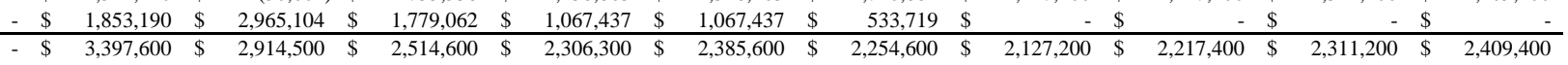

Cash Flows Capital Financing and Investing Activities

\begin{tabular}{lcc} 
Cash Flows Capital Financing and Investing Activities & $\$$ & 529,100 \\
\hline Proceeds From SGIP Rebate & $\$$ & $8,499,800$ \\
Proceeds From Debt & $\$(10,032,100)$ \\
Capital Acquisition Payments &
\end{tabular}

Capital Acquisition Payments

$(10,032,100)$

Net Cash Flows Capital Financing and Investing Activities

Net Increase (Decrease) in Cash

Cumulative Positive Cash Flows

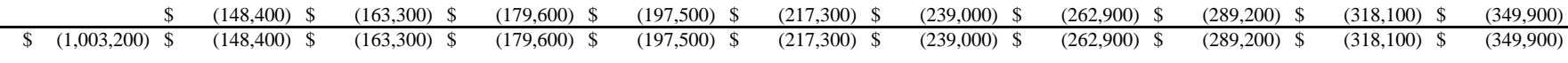

Net Present Value

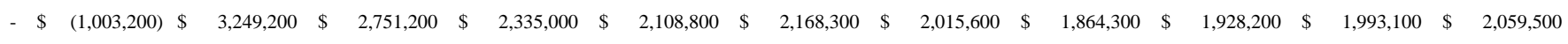

Discount Rate 
APPENDIX C - PROCESS CHEMICAL STREAMS 
Ampac Fine Chemicals

Combined Heat and Power Project

Hazardous Solvent and Aqueous Streams

ACC-261/278 Solvent

\begin{tabular}{|c|c|c|}
\hline Chemical & Wt. & $\%$ \\
\hline Heptane & 18 & $41.9 \%$ \\
\hline Ethanol & 25 & $58.1 \%$ \\
\hline Total Weight per Batch, kg & 43 & $100.0 \%$ \\
\hline Total Volume, L & 57.3 & \\
\hline Total Volume, Gal & 15.1 & \\
\hline
\end{tabular}

S:\Documentation Center\Process\262,261,308-L059(s)\ACC261-FY2007\ACC261_278 Material Balance\MB ACC-261\&278 rev 1 20061016.xIs

\section{ACC-321/322 Solvent}

\begin{tabular}{|c|c|c|}
\hline Chemical & Wt. & $\%$ \\
\hline Heptane & 88 & $39.6 \%$ \\
\hline Ethanol & 134 & $60.4 \%$ \\
\hline Total Weight per Batch, kg & 222 & $100.0 \%$ \\
\hline Total Volume, L & 296.0 & \\
\hline Total Volume, Gal & 78.2 & \\
\hline
\end{tabular}

STRIDE Charts.xls avg 2006-2009

\section{NOTES}

Mass balance does not account for cleaning or CSP regeneration, etc...

No aqueous waste streams produced by this process 
Ampac Fine Chemicals

Combined Heat and Power Project

Hazardous Solvent and Aqueous Streams

\begin{tabular}{|c|c|c|}
\hline ACC-262 Solvent & & \\
\hline Chemical & Wt. & $\%$ \\
\hline Acetone & 5358.0 & $97.57 \%$ \\
\hline Toluene & 23.6 & $0.43 \%$ \\
\hline Carbon & 0.0 & $0.00 \%$ \\
\hline Dicalite & 0.0 & $0.00 \%$ \\
\hline Water & 0.0 & $0.00 \%$ \\
\hline Monoalkylated ABA & 0.0 & $0.00 \%$ \\
\hline Dialkylated ABA & 0.0 & $0.00 \%$ \\
\hline$A B A$ & 0.0 & $0.00 \%$ \\
\hline Others & 0.0 & $0.00 \%$ \\
\hline Hydroxypyridine & 0.0 & $0.00 \%$ \\
\hline LO59 & 109.6 & $2.00 \%$ \\
\hline Ethanol & 0.0 & $0.00 \%$ \\
\hline Total Weight per Batch, kg & 5491.23 & $100.00 \%$ \\
\hline Stream Density, kg/L & 0.79 & \\
\hline Total Volume, L & 6782.28 & \\
\hline Total Volume, Gal & 1791.88 & \\
\hline
\end{tabular}

mb - ACC262-2006IACC262 Mass Balancelmb-ACC262-R01 New Process.xls

NOTES

Mass balance does not account for cleaning

No aqueous waste streams produced by this process 
Ampac Fine Chemicals

Combined Heat and Power Project

Hazardous Solvent and Aqueous Streams

ACC-308/324 Solvent @ 05063
\begin{tabular}{|l|r|r|}
\hline \multicolumn{1}{|c|}{ Chemical } & \multicolumn{1}{|c|}{ Wt. } & \multicolumn{1}{|c|}{$\%$} \\
\hline other & 2.50 & $0.1 \%$ \\
Methanol & 2094.92 & $82.6 \%$ \\
Sodium Methoxide & 20.00 & $0.8 \%$ \\
Etiracetam (50/50 of LO60/LO59) & 418.98 & $16.5 \%$ \\
\hline Total Weight per Batch, kg & 2536.42 & $100.0 \%$ \\
Stream Density, kg/L & 0.80 & \\
Total Volume, L & 3188.02 & \\
Total Volume, Gal & 842.28 & \\
\hline
\end{tabular}

S:IDocumentation CenterlProcess|262,261,308-L059(s)VACC308-2009VACC-308-Building 05-063lACC308-mass balancelmb-ACC308-20081212-R01b.xls

ACC-308/324 05133
\begin{tabular}{|l|c|r|}
\hline \multicolumn{1}{|c|}{ Chemical } & Wt. & \multicolumn{1}{c|}{$\%$} \\
\hline Other & 0.00 & $0.0 \%$ \\
Methanol & 2299.66 & $79.6 \%$ \\
Sodium Methoxide & 20.00 & $0.7 \%$ \\
Etiracetam (50/50 of LO60/LO59) & 568.26 & $19.7 \%$ \\
\hline Total Weight per Batch, kg & 2887.92 & $100.0 \%$ \\
Stream Density, kg/L & 0.98 & \\
Total Volume, L & 2951.73 & \\
Total Volume, Gal & 779.85 & \\
\hline
\end{tabular}

S:IDocumentation CenterIProcessI262,261,308-L059(s)VACC308-2006IMass BalancelACC308_MB_with and wo recycled centrate 2006.xIs

\section{NOTES}

Mass balance does not account for cleaning

No aqueous waste streams produced by this process 
Ampac Fine Chemicals

Combined Heat and Power Project

Hazardous Solvent and Aqueous Streams

ACC-322 Solvent
\begin{tabular}{|l|c|c|}
\hline \multicolumn{1}{|c|}{ Chemical } & Wt. & $\%$ \\
\hline Acetone & 40.6 & $89.62 \%$ \\
Dicalite & 4.7 & $10.38 \%$ \\
LO59 & & $0.00 \%$ \\
\hline Total Weight per Batch, kg & 45.30 & $100.00 \%$ \\
Stream Density, kg/L & 0.84 & \\
Total Volume, L & 53.65 & \\
Total Volume, Gal & 14.17 & \\
\hline
\end{tabular}

mb-ACC322-Acetone Distillation 01-31-12.xls

NOTES

Acetone recycling of centrate. Only waste stream considered was from the dryer vent Mass balance does not account for cleaning

No aqueous waste streams produced by this process 
Ampac Fine Chemicals

Combined Heat and Power Project

Hazardous Solvent and Aqueous Streams

ACC-322 Acetone Recovery Solvent

\begin{tabular}{|l|c|c|}
\hline \multicolumn{1}{|c|}{ Chemical } & Wt. & \% \\
\hline Acetone & 223.69 & $75.00 \%$ \\
LO59 & 74.56 & $25.00 \%$ \\
\hline Total Weight per Batch, kg & 298.26 & $100.00 \%$ \\
Stream Density, kg/L & 0.83 & \\
Total Volume, L & 361.28 & \\
Total Volume, Gal & 95.44 & \\
\hline
\end{tabular}

mb-ACC322-Acetone Distillation 01-31-12.xls

NOTES

Mass balance does not account for cleaning

No aqueous waste streams produced by this process 
Ampac Fine Chemicals

Combined Heat and Power Project

Hazardous Solvent and Aqueous Streams

ACC-268 Solvent

\begin{tabular}{|l|c|c|}
\hline \multicolumn{1}{|c|}{ Chemical } & Wt. & \% \\
\hline Adenine, kg & 1.95 & $0.0 \%$ \\
(R)-1,2-Propylene carbonate, kg & 75.90 & $0.8 \%$ \\
Toluene, kg & 3412.42 & $38.1 \%$ \\
Acetone, kg & 765.86 & $6.7 \%$ \\
NaOH, kg & 7.80 & $0.1 \%$ \\
Methanesulfonic Acid, kg & 87.80 & $1.0 \%$ \\
Dimethylformamide (DMF), kg & 2405.00 & $26.8 \%$ \\
HPA, kg & 124.60 & $1.4 \%$ \\
Carbon Dioxide, kg & 0.00 & $0.0 \%$ \\
Ethanol, kg & 1949.29 & $21.8 \%$ \\
Other, kg & 129.05 & $1.4 \%$ \\
Water & 0.00 & $0.0 \%$ \\
Methanol & 165.00 & $1.8 \%$ \\
\hline Total Weight per Batch, kg & 9124.67 & $100.0 \%$ \\
Stream Density, kg/L & 0.86 & \\
Total Volume, L & 10610.08 & \\
Total Volume, Gal & 2803.19 & \\
\hline
\end{tabular}

S:IDocumentation CenterlProcessl270,268,269.288,289-TDFIACC268-2008IACC268-Mass Balancelmb-ACC268 (650 kg)-20080205.xls

\section{NOTES}

No viable aqueous waste streams produced by this process. 
Ampac Fine Chemicals

Combined Heat and Power Project

Hazardous Solvent and Aqueous Streams

ACC-288 Solvent

\begin{tabular}{|l|c|c|}
$\mid$ \\
\hline Chemical & Wt. & $\%$ \\
\hline Adenine, kg & 0.00 & $0.0 \%$ \\
(R)-1,2-Propylene carbonate, kg & 0.00 & $0.0 \%$ \\
Toluene, kg & 406.18 & $9.9 \%$ \\
Acetone, kg & 1050.00 & $25.6 \%$ \\
NaOH, kg & 0.00 & $0.0 \%$ \\
Methanesulfonic Acid, kg & 0.00 & $0.0 \%$ \\
Dimethylformamide (DMF), kg & 624.26 & $15.2 \%$ \\
HPA, kg & 0.25 & $0.0 \%$ \\
Carbon Dioxide, kg & 0.00 & $0.0 \%$ \\
Magnesium t-butoxide, kg & 2.13 & $0.1 \%$ \\
Tosylate Reagent, kg & 5.04 & $0.1 \%$ \\
Mg(OTs)2, kg & 15.42 & $0.4 \%$ \\
Diethyl PMPA, kg & 0.58 & $0.0 \%$ \\
t-Butanol, kg & 0.00 & $0.0 \%$ \\
Water, kg & 176.08 & $4.3 \%$ \\
Hydrogen Bromide, kg & 13.00 & $0.3 \%$ \\
Ethyl Bromide, kg & 359.31 & $8.8 \%$ \\
Dimethylamine hydrobromide & 1.13 & $0.0 \%$ \\
Carbon monoxide, kg & 0.00 & $0.0 \%$ \\
t-butylbromide, kg & 276.19 & $6.7 \%$ \\
Magnesium bromide, kg & 1.53 & $0.0 \%$ \\
Ethyl Acetate, kg & 1133.47 & $27.6 \%$ \\
Other (PMPA-HBr), kg & 0.00 & 0.00 \\
PMPA, kg & 23.68 & 0.01 \\
Sodium Bromide & 15.42 & 0.00 \\
Methanol & 0.00 & 0.00 \\
\hline Total Weight per Batch, kg & 4103.67 & $100.0 \%$ \\
Stream Density, kg/L & 0.92 & \\
Total Volume, L & 4450.10 & \\
Total Volume, Gal & 1175.72 & \\
\hline
\end{tabular}

\section{ACC-288 Aqueous}

\begin{tabular}{|c|c|c|}
\hline Chemical & Wt. & $\%$ \\
\hline Adenine, $\mathrm{kg}$ & 0.00 & $0.0 \%$ \\
\hline (R)-1,2-Propylene carbonate, $\mathrm{kg}$ & 0.00 & $0.0 \%$ \\
\hline Toluene, kg & 1.32 & $0.0 \%$ \\
\hline Acetone, $\mathrm{kg}$ & 1081.41 & $5.7 \%$ \\
\hline $\mathrm{NaOH}, \mathrm{kg}$ & 0.91 & $0.0 \%$ \\
\hline Methanesulfonic Acid, kg & 0.00 & $0.0 \%$ \\
\hline Dimethylformamide (DMF), kg & 55.69 & $0.3 \%$ \\
\hline HPA, kg & 4.70 & $0.0 \%$ \\
\hline Carbon Dioxide, kg & 0.00 & $0.0 \%$ \\
\hline Magnesium t-butoxide, $\mathrm{kg}$ & 40.50 & $0.2 \%$ \\
\hline Tosylate Reagent, kg & 79.70 & $0.4 \%$ \\
\hline $\mathrm{Mg}(\mathrm{OTs}) 2, \mathrm{~kg}$ & 293.03 & $1.6 \%$ \\
\hline Diethyl PMPA, kg & 10.97 & $0.1 \%$ \\
\hline t-Butanol, kg & 0.00 & $0.0 \%$ \\
\hline Water, kg & 16695.30 & $88.4 \%$ \\
\hline Hydrogen Bromide, kg & 0.00 & $0.0 \%$ \\
\hline Ethyl Bromide, kg & 0.00 & $0.0 \%$ \\
\hline Dimethylamine hydrobromide & 21.38 & $0.1 \%$ \\
\hline Carbon monoxide, $\mathrm{kg}$ & 0.00 & $0.0 \%$ \\
\hline t-butylbromide, kg & 0.00 & $0.0 \%$ \\
\hline Magnesium bromide, $\mathrm{kg}$ & 29.15 & $0.2 \%$ \\
\hline Ethyl Acetate, kg & 186.53 & $1.0 \%$ \\
\hline Other (PMPA-HBr), kg & 0.00 & 0.00 \\
\hline PMPA, kg & 68.85 & 0.00 \\
\hline Sodium Bromide & 314.08 & 0.02 \\
\hline Methanol & 0.00 & 0.00 \\
\hline Total Weight per Batch, kg & 18883.52 & $100.0 \%$ \\
\hline Stream Density, kg/L & 1.00 & \\
\hline Total Volume, L & 18814.87 & \\
\hline Total Volume, Gal & 4970.90 & \\
\hline
\end{tabular}


Ampac Fine Chemicals

Combined Heat and Power Project

Hazardous Solvent and Aqueous Streams

\section{ACC-289 Solvent}

\begin{tabular}{|l|c|c|}
\hline \multicolumn{1}{|c|}{ Chemical } & Wt. & $\%$ \\
\hline Acetone, kg & 2695.00 & $12.05 \%$ \\
NaOH, kg & 0.00 & $0.00 \%$ \\
Methanesulfonic Acid, kg & 0.00 & $0.00 \%$ \\
Dimethylformamide (DMF), kg & 0.00 & $0.00 \%$ \\
HPA, kg & 0.00 & $0.00 \%$ \\
Carbon Dioxide, kg & 0.00 & $0.00 \%$ \\
Magnesium t-butoxide, kg & 0.00 & $0.00 \%$ \\
Tosylate Reagent, kg & 0.00 & $0.00 \%$ \\
Mg(OTs)2, kg & 0.00 & $0.00 \%$ \\
Diethyl PMPA, kg & 0.00 & $0.00 \%$ \\
t-Butanol, kg & 0.00 & $0.00 \%$ \\
Water, kg & 46.68 & $0.21 \%$ \\
Bromotrimethylsilane, kg & 0.00 & $0.00 \%$ \\
Hydrogen Bromide, kg & 0.00 & $0.00 \%$ \\
Ethyl Bromide, kg & 0.00 & $0.00 \%$ \\
Ethyl Acetate, kg & 0.00 & $0.00 \%$ \\
((CH3)3Si)2O, kg & 0.00 & $0.00 \%$ \\
TD + Other, kg & 9.32 & $0.04 \%$ \\
PMPA, kg & 0.00 & $0.00 \%$ \\
NMP (1-methyl-2-pyrrolidinone) & 2071.89 & $9.27 \%$ \\
TEA, kg & 257.65 & $1.15 \%$ \\
Chloromethyl-2-propylcarbonate, & 578.18 & $2.59 \%$ \\
Hydrogen Chloride, 37\% & 0.00 & $0.00 \%$ \\
Hydroxylamine (Freebase) & 0.27 & $0.00 \%$ \\
N6-Hydroxymethyl & 2.38 & $0.01 \%$ \\
Oxime & 3.50 & $0.02 \%$ \\
Ammonium Acetate & 1.31 & $0.01 \%$ \\
Magnesium Sulfate & 0.00 & $0.00 \%$ \\
Isopropyl acetate, kg & 7532.17 & $33.68 \%$ \\
Sodium Chloride, kg & 2.68 & $0.01 \%$ \\
Fumaric acid, kg & 88.01 & $0.39 \%$ \\
Silica gel, kg & 0.00 & $0.00 \%$ \\
IPA, kg & 2349.86 & $10.51 \%$ \\
PMPA-TEA Salt, kg & 20.85 & $0.09 \%$ \\
Tenofovir DF, kg & 53.85 & $0.24 \%$ \\
TEA-HCl, kg & 0.00 & $0.00 \%$ \\
IsoPropyl ether, kg & 0.00 & $0.00 \%$ \\
CIP-100 & 2362.53 & $100.00 \%$ \\
\hline Total Weight per Batch, kg & \\
Stream Density, kg/L & \\
Total Volume, L & \\
Total Volume, Gal & & \\
SIDocumeng & \\
\hline
\end{tabular}

\section{ACC-289 Aqueous}

\begin{tabular}{|l|c|c|}
\hline \multicolumn{1}{|c|}{ Chemical } & Wt. & $\%$ \\
\hline Acetone, kg & 0.00 & $0.00 \%$ \\
NaOH, kg & 0.00 & $0.00 \%$ \\
Methanesulfonic Acid, kg & 0.00 & $0.00 \%$ \\
Dimethylformamide (DMF), kg & 0.00 & $0.00 \%$ \\
HPA, kg & 0.00 & $0.00 \%$ \\
Carbon Dioxide, kg & 0.00 & $0.00 \%$ \\
Magnesium t-butoxide, kg & 0.00 & $0.00 \%$ \\
Tosylate Reagent, kg & 0.00 & $0.00 \%$ \\
Mg(OTs)2, kg & 0.00 & $0.00 \%$ \\
Diethyl PMPA, kg & 0.00 & $0.00 \%$ \\
t-Butanol, kg & 0.00 & $0.00 \%$ \\
Water, kg & 11148.61 & $74.40 \%$ \\
Bromotrimethylsilane, kg & 0.00 & $0.00 \%$ \\
Hydrogen Bromide, kg & 0.00 & $0.00 \%$ \\
Ethyl Bromide, kg & 0.00 & $0.00 \%$ \\
Ethyl Acetate, kg & 0.00 & $0.00 \%$ \\
((CH3)3Si)2O, kg & 0.00 & $0.00 \%$ \\
TD + Other, kg & 76.88 & $0.51 \%$ \\
PMPA, kg & 0.00 & $0.00 \%$ \\
NMP (1-methyl-2-pyrrolidinone) & 1393.05 & $9.30 \%$ \\
TEA, kg & 0.00 & $0.00 \%$ \\
Chloromethyl-2-propylcarbonate, kg & 18.95 & $0.13 \%$ \\
Hydrogen Chloride, 37\% & 34.16 & $0.23 \%$ \\
Hydroxylamine (Freebase) & 22.52 & $0.15 \%$ \\
N6-Hydroxymethyl & 3.37 & $0.02 \%$ \\
Oxime & 0.93 & $0.01 \%$ \\
Ammonium Acetate & 648.39 & $4.33 \%$ \\
Magnesium Sulfate & 365.00 & $2.44 \%$ \\
Isopropyl acetate, kg & 144.33 & $0.96 \%$ \\
Sodium Chloride, kg & 577.67 & $3.85 \%$ \\
Fumaric acid, kg & 0.00 & $0.00 \%$ \\
Silica gel, kg & 0.00 & $0.00 \%$ \\
IPA, kg & 0.00 & $0.00 \%$ \\
PMPA-TEA Salt, kg & 23.64 & $0.16 \%$ \\
Tenofovir DF, kg & 0.00 & $0.00 \%$ \\
TEA-HCl, kg & 527.48 & $3.52 \%$ \\
IsoPropyl ether, kg & 0.00 & $0.00 \%$ \\
CIP-100 & 0.00 & $0.00 \%$ \\
\hline Total Weight per Batch, kg & 1494.96 & $100.00 \%$ \\
Stream Density, kg/L & \\
Total Volume, L & \\
Total Volume, Gal & 3802.99 & \\
\hline
\end{tabular}

S:IDocumentation CenterlProcess|270,268,269.288,289-TDFIACC289-2011IMass BalancelTDF - NuPOC LLC 2011MB Plant 1 20110620 365kg.xIsX 
Ampac Fine Chemicals

Combined Heat and Power Project

Hazardous Solvent and Aqueous Streams

ACC-289 IPE Recovery Solvent

\begin{tabular}{|l|c|c|}
\hline \multicolumn{1}{|c|}{ Chemical } & Wt. & $\%$ \\
\hline Water, kg & 0.08 & $0.02 \%$ \\
TD + Other, kg & 0.03 & $0.01 \%$ \\
NMP (1-methyl-2-pyrrolidinone), kg & 0.00 & $0.00 \%$ \\
Chloromethyl-2-propylcarbonate, kg & 7.79 & $1.52 \%$ \\
Isopropyl acetate, kg & 0.53 & $0.10 \%$ \\
Fumaric acid, kg & 0.00 & $0.00 \%$ \\
IPA, kg & 5.87 & $1.15 \%$ \\
Tenofovir DF, kg & 0.00 & $0.00 \%$ \\
IsoPropyl ether, kg & 497.01 & $97.15 \%$ \\
BHT (Butylhydroxytoluene), kg & 0.27 & $0.05 \%$ \\
\hline Total Weight per Batch, kg & 511.58 & $100.00 \%$ \\
Stream Density, kg/L & 0.73 & \\
Total Volume, L & 700.53 & \\
Total Volume, Gal & 185.08 & \\
\hline
\end{tabular}

ACC-289 IPE Recovery Aqueous

\begin{tabular}{|l|c|c|}
\hline \multicolumn{1}{|c|}{ Chemical } & Wt. & $\%$ \\
\hline Water, kg & 22696.60 & $99.47 \%$ \\
TD + Other, kg & 0.00 & $0.00 \%$ \\
NMP (1-methyl-2-pyrrolidinone), kg & 1.73 & $0.34 \%$ \\
Chloromethyl-2-propylcarbonate, kg & 0.00 & $0.00 \%$ \\
Isopropyl acetate, kg & 0.00 & $0.00 \%$ \\
Fumaric acid, kg & 2.13 & $0.42 \%$ \\
IPA, kg & 51.09 & $9.99 \%$ \\
Tenofovir DF, kg & 17.27 & $3.38 \%$ \\
IsoPropyl ether, kg & 49.35 & $9.65 \%$ \\
BHT (Butylhydroxytoluene), kg & 0.00 & $0.00 \%$ \\
\hline Total Weight per Batch, kg & 22818.17 & $4460.33 \%$ \\
Stream Density, kg/L & 1.00 & \\
Total Volume, L & 22882.08 & \\
Total Volume, Gal & 6045.46 & \\
\hline
\end{tabular}

S:IDocumentation Center|ProcessI270,268,269.288,289-TDFIACC289-2011IMass BalancelIPE Recoverylmb-ACC289-IPE Recovery-05132-20110817.xlsx 
Ampac Fine Chemicals

Combined Heat and Power Project

Hazardous Solvent and Aqueous Streams

ACC-342.1 Solvent

\begin{tabular}{|c|c|c|}
\hline Chemical & Wt. & $\%$ \\
\hline INCB032182, Comp 3 & 0.00 & $0.00 \%$ \\
\hline Potassium Carbonate,kg & 0.00 & $0.00 \%$ \\
\hline 1-Butanol,kg & 243.00 & $18.22 \%$ \\
\hline Hydrochloric Acid, kg & 0.00 & $0.00 \%$ \\
\hline Potassium Borate?, kg & 0.00 & $0.00 \%$ \\
\hline Paladium catalyst,kg & 0.00 & $0.00 \%$ \\
\hline Water, kg & 8.57 & $0.64 \%$ \\
\hline Acetonitrile,kg & 0.00 & $0.00 \%$ \\
\hline 4-Chloro (Compound 1) & 0.00 & $0.00 \%$ \\
\hline SEM-Cl (compound 2) & 0.00 & $0.00 \%$ \\
\hline Ethyl Acetate, kg & 0.00 & $0.00 \%$ \\
\hline $\mathrm{NaOH}, \mathrm{kg}$ & 0.00 & $0.00 \%$ \\
\hline Charcoal & 0.00 & $0.00 \%$ \\
\hline Celite & 0.00 & $0.00 \%$ \\
\hline Dimethylacetamide DMAC & 0.26 & $0.02 \%$ \\
\hline Sodium Hydride,60\% & 0.00 & $0.00 \%$ \\
\hline Sodium Chloride, $\mathrm{kg}$ & 0.00 & $0.00 \%$ \\
\hline WPT1710-225 & 0.00 & $0.00 \%$ \\
\hline Tetrahydrofuran,kg & 0.00 & $0.00 \%$ \\
\hline INCB032304, Comp 5 & 0.00 & $0.00 \%$ \\
\hline INCB032304*Phosphate & 0.00 & $0.00 \%$ \\
\hline Sodium Phosphate & 0.00 & $0.00 \%$ \\
\hline Pinacol,kg & 0.00 & $0.00 \%$ \\
\hline Acetaldehyde, $\mathrm{kg}$ & 0.00 & $0.00 \%$ \\
\hline Ethanol & 0.00 & $0.00 \%$ \\
\hline Methanol & 299.39 & $22.44 \%$ \\
\hline Potassium Chloride,kg & 0.00 & $0.00 \%$ \\
\hline paraformaldehyde,kg & 0.67 & $0.05 \%$ \\
\hline $\mathrm{DBU} * \mathrm{HCl}$ & 0.00 & $0.00 \%$ \\
\hline Carbon Dioxide,kg & 0.00 & $0.00 \%$ \\
\hline DBU & 0.00 & $0.00 \%$ \\
\hline INCB032181, Comp 8 & 0.00 & $0.00 \%$ \\
\hline INCB032309, Comp 9 & 0.00 & $0.00 \%$ \\
\hline INCB032306, Comp 10R & 0.00 & $0.00 \%$ \\
\hline TBME,kg & 779.23 & $58.41 \%$ \\
\hline Heptane,kg & 0.00 & $0.00 \%$ \\
\hline Cesium Chloride, $\mathrm{kg}$ & 0.00 & $0.00 \%$ \\
\hline Isopropanol,kg & 0.00 & $0.00 \%$ \\
\hline Lithium Tetrafluoroborate & 0.00 & $0.00 \%$ \\
\hline Sodium Bicarbonate,kg & 0.00 & $0.00 \%$ \\
\hline Ammonium hydroxide,kg & 0.00 & $0.00 \%$ \\
\hline Cesium Carbonate,kg & 0.00 & $0.00 \%$ \\
\hline INCB018424, Comp 11 & 0.00 & $0.00 \%$ \\
\hline INCB021499,kg & 0.00 & $0.00 \%$ \\
\hline 85\% Phosphoric acid,kg & 0.00 & $0.00 \%$ \\
\hline INCB018424 Phosphate & 0.00 & $0.00 \%$ \\
\hline Trimethylsilylethanol,kg & 2.66 & $0.20 \%$ \\
\hline Hydrogen & 0.00 & $0.00 \%$ \\
\hline pyrimidine sodium & 0.00 & $0.00 \%$ \\
\hline DCM, methylene chloride & 0.00 & $0.00 \%$ \\
\hline DME, Dimethoxyethane & 0.00 & $0.00 \%$ \\
\hline Mineral Oil & 0.26 & $0.02 \%$ \\
\hline Total Weight per Batch,kg & 1334.04 & $100.00 \%$ \\
\hline Stream Density, kg/L & 0.76 & \\
\hline Total Volume, L & 1744.57 & \\
\hline Total Volume, Gal & 460.92 & \\
\hline
\end{tabular}

ACC-342.1 Aqueous

\begin{tabular}{|c|c|c|}
\hline Chemical & Wt. & $\%$ \\
\hline INCB032182, Comp 3 & 19.46 & $1.00 \%$ \\
\hline Potassium Carbonate, $\mathrm{kg}$ & 0.00 & $0.00 \%$ \\
\hline 1-Butanol,kg & 0.00 & $0.00 \%$ \\
\hline Hydrochloric Acid, kg & 0.00 & $0.00 \%$ \\
\hline Potassium Borate?, kg & 0.00 & $0.00 \%$ \\
\hline Paladium catalyst,kg & 0.00 & $0.00 \%$ \\
\hline Water, kg & 1108.92 & $57.15 \%$ \\
\hline Acetonitrile,kg & 0.00 & $0.00 \%$ \\
\hline 4-Chloro (Compound 1) & 0.05 & $0.00 \%$ \\
\hline SEM-Cl (compound 2) & 0.00 & $0.00 \%$ \\
\hline Ethyl Acetate, kg & 0.00 & $0.00 \%$ \\
\hline $\mathrm{NaOH}, \mathrm{kg}$ & -0.22 & $-0.01 \%$ \\
\hline Charcoal & 0.00 & $0.00 \%$ \\
\hline Celite & 0.00 & $0.00 \%$ \\
\hline Dimethylacetamide DMAC & 480.85 & $24.78 \%$ \\
\hline Sodium Hydride,60\% & 0.00 & $0.00 \%$ \\
\hline Sodium Chloride, kg & 195.10 & $10.06 \%$ \\
\hline WPT1710-225 & 0.00 & $0.00 \%$ \\
\hline Tetrahydrofuran,kg & 0.00 & $0.00 \%$ \\
\hline INCB032304, Comp 5 & 0.00 & $0.00 \%$ \\
\hline INCB032304*Phosphate & 0.00 & $0.00 \%$ \\
\hline Sodium Phosphate & 0.00 & $0.00 \%$ \\
\hline Pinacol,kg & 0.00 & $0.00 \%$ \\
\hline Acetaldehyde, kg & 0.00 & $0.00 \%$ \\
\hline Ethanol & 0.00 & $0.00 \%$ \\
\hline Methanol & 0.00 & $0.00 \%$ \\
\hline Potassium Chloride,kg & 0.00 & $0.00 \%$ \\
\hline paraformaldehyde,kg & 0.35 & $0.02 \%$ \\
\hline $\mathrm{DBU}{ }^{*} \mathrm{HCl}$ & 0.00 & $0.00 \%$ \\
\hline Carbon Dioxide,kg & 0.00 & $0.00 \%$ \\
\hline DBU & 0.00 & $0.00 \%$ \\
\hline INCB032181, Comp 8 & 0.00 & $0.00 \%$ \\
\hline INCB032309, Comp 9 & 0.00 & $0.00 \%$ \\
\hline INCB032306, Comp 10R & 0.00 & $0.00 \%$ \\
\hline TBME,kg & 132.38 & $6.82 \%$ \\
\hline Heptane,kg & 0.00 & $0.00 \%$ \\
\hline Cesium Chloride, $\mathrm{kg}$ & 0.00 & $0.00 \%$ \\
\hline Isopropanol,kg & 0.00 & $0.00 \%$ \\
\hline Lithium Tetrafluoroborate & 0.00 & $0.00 \%$ \\
\hline Sodium Bicarbonate,kg & 0.00 & $0.00 \%$ \\
\hline Ammonium hydroxide,kg & 0.00 & $0.00 \%$ \\
\hline Cesium Carbonate,kg & 0.00 & $0.00 \%$ \\
\hline INCB018424, Comp 11 & 0.00 & $0.00 \%$ \\
\hline INCB021499,kg & 0.00 & $0.00 \%$ \\
\hline 85\% Phosphoric acid,kg & 0.00 & $0.00 \%$ \\
\hline INCB018424 Phosphate & 0.00 & $0.00 \%$ \\
\hline Trimethylsilylethanol,kg & 1.36 & $0.07 \%$ \\
\hline Hydrogen & 0.00 & $0.00 \%$ \\
\hline pyrimidine sodium & 0.68 & $0.04 \%$ \\
\hline DCM, methylene chloride & 0.00 & $0.00 \%$ \\
\hline DME, Dimethoxyethane & 0.00 & $0.00 \%$ \\
\hline Mineral Oil & 1.28 & $0.07 \%$ \\
\hline $\begin{array}{l}\text { Total Weight per Batch,kg } \\
\text { Stream Density, kg/L } \\
\text { Total Volume, L } \\
\text { Total Volume, Gal }\end{array}$ & $\begin{array}{c}1940.20 \\
1.01 \\
1918.63 \\
506.90\end{array}$ & $100.00 \%$ \\
\hline
\end{tabular}


Ampac Fine Chemicals

Combined Heat and Power Project

Hazardous Solvent and Aqueous Streams

ACC-342.2 Solvent

\begin{tabular}{|c|c|c|}
\hline Chemical & Wt. & $\%$ \\
\hline INCB032183, WPT1710-212 & 0.00 & $0.00 \%$ \\
\hline INCB032182, Comp 3 & 0.00 & $0.00 \%$ \\
\hline Potassium Carbonate, $\mathrm{kg}$ & 0.00 & $0.00 \%$ \\
\hline 1-Butanol,kg & 305.20 & $17.61 \%$ \\
\hline Hydrochloric Acid, kg & 0.00 & $0.00 \%$ \\
\hline Potassium Borate?, kg & 0.00 & $0.00 \%$ \\
\hline Paladium catalyst,kg & 0.00 & $0.00 \%$ \\
\hline Water, kg & 325.90 & $18.81 \%$ \\
\hline Acetonitrile,kg & 1.57 & $0.09 \%$ \\
\hline 4-Chloro (Compound 1) & 0.00 & $0.00 \%$ \\
\hline SEM-Cl (compound 2) & 0.00 & $0.00 \%$ \\
\hline Ethyl Acetate, $\mathrm{kg}$ & 782.73 & $45.17 \%$ \\
\hline $\mathrm{NaOH}, \mathrm{kg}$ & 0.00 & $0.00 \%$ \\
\hline Charcoal & 0.00 & $0.00 \%$ \\
\hline Celite & 0.00 & $0.00 \%$ \\
\hline Dimethylacetamide DMAC & 0.00 & $0.00 \%$ \\
\hline Sodium Hydride, $60 \%$ & 0.00 & $0.00 \%$ \\
\hline Sodium Chloride, $\mathrm{kg}$ & 0.00 & $0.00 \%$ \\
\hline WPT1710-225 & 0.00 & $0.00 \%$ \\
\hline Tetrahydrofuran,kg & 0.00 & $0.00 \%$ \\
\hline INCB032304, Comp 5 & 0.00 & $0.00 \%$ \\
\hline INCB032304*Phosphate & 0.00 & $0.00 \%$ \\
\hline Sodium Phosphate & 0.00 & $0.00 \%$ \\
\hline Pinacol,kg & 10.89 & $0.63 \%$ \\
\hline Acetaldehyde, $\mathrm{kg}$ & 0.00 & $0.00 \%$ \\
\hline Ethanol & 0.00 & $0.00 \%$ \\
\hline Methanol & 299.39 & $17.28 \%$ \\
\hline Potassium Chloride,kg & 0.00 & $0.00 \%$ \\
\hline paraformaldehyde,kg & 0.21 & $0.01 \%$ \\
\hline $\mathrm{DBU}{ }^{*} \mathrm{HCl}$ & 0.00 & $0.00 \%$ \\
\hline Carbon Dioxide,kg & 0.00 & $0.00 \%$ \\
\hline DBU & 0.00 & $0.00 \%$ \\
\hline INCB032181, Comp 8 & 0.00 & $0.00 \%$ \\
\hline INCB032309, Comp 9 & 0.00 & $0.00 \%$ \\
\hline INCB032306, Comp 10R & 0.00 & $0.00 \%$ \\
\hline TBME,kg & 0.00 & $0.00 \%$ \\
\hline Heptane,kg & 0.02 & $0.00 \%$ \\
\hline Cesium Chloride, $\mathrm{kg}$ & 0.00 & $0.00 \%$ \\
\hline Isopropanol,kg & 0.00 & $0.00 \%$ \\
\hline Lithium Tetrafluoroborate & 0.00 & $0.00 \%$ \\
\hline Sodium Bicarbonate,kg & 0.00 & $0.00 \%$ \\
\hline Ammonium hydroxide, $\mathrm{kg}$ & 0.00 & $0.00 \%$ \\
\hline Cesium Carbonate,kg & 0.00 & $0.00 \%$ \\
\hline INCB018424, Comp 11 & 0.00 & $0.00 \%$ \\
\hline INCB021499,kg & 0.00 & $0.00 \%$ \\
\hline 85\% Phosphoric acid,kg & 0.00 & $0.00 \%$ \\
\hline INCB018424 Phosphate & 0.00 & $0.00 \%$ \\
\hline Trimethylsilylethanol,kg & 5.63 & $0.32 \%$ \\
\hline Hydrogen & 0.00 & $0.00 \%$ \\
\hline pyrimidine sodium & 0.00 & $0.00 \%$ \\
\hline DCM, methylene chloride & 0.00 & $0.00 \%$ \\
\hline DME, Dimethoxyethane & 0.00 & $0.00 \%$ \\
\hline Mineral Oil & 1.27 & $0.07 \%$ \\
\hline Total Weight per Batch,kg & 1732.82 & $100.00 \%$ \\
\hline Stream Density, kg/L & 0.88 & \\
\hline Total Volume, L & 1966.84 & \\
\hline Total Volume, Gal & 519.64 & \\
\hline
\end{tabular}

ACC-342.2 Aqueous

\begin{tabular}{|c|c|c|}
\hline Chemical & Wt. & $\%$ \\
\hline INCB032183, WPT1710-212 & 23.10 & $1.33 \%$ \\
\hline INCB032182, Comp 3 & 0.80 & $0.05 \%$ \\
\hline Potassium Carbonate, $\mathrm{kg}$ & 39.75 & $2.29 \%$ \\
\hline 1-Butanol,kg & 129.66 & $7.48 \%$ \\
\hline Hydrochloric Acid, kg & 0.00 & $0.00 \%$ \\
\hline Potassium Borate?, kg & 123.63 & $7.13 \%$ \\
\hline Paladium catalyst, $\mathrm{kg}$ & 0.00 & $0.00 \%$ \\
\hline Water, kg & 7296.38 & $421.07 \%$ \\
\hline Acetonitrile,kg & 677.84 & $39.12 \%$ \\
\hline 4-Chloro (Compound 1) & 0.41 & $0.02 \%$ \\
\hline SEM-Cl (compound 2) & 0.00 & $0.00 \%$ \\
\hline Ethyl Acetate, kg & 285.18 & $16.46 \%$ \\
\hline $\mathrm{NaOH}, \mathrm{kg}$ & 3.74 & $0.22 \%$ \\
\hline Charcoal & 0.00 & $0.00 \%$ \\
\hline Celite & 0.00 & $0.00 \%$ \\
\hline Dimethylacetamide DMAC & 0.08 & $0.00 \%$ \\
\hline Sodium Hydride, $60 \%$ & 0.00 & $0.00 \%$ \\
\hline Sodium Chloride, $\mathrm{kg}$ & 127.72 & $7.37 \%$ \\
\hline WPT1710-225 & 2.55 & $0.15 \%$ \\
\hline Tetrahydrofuran,kg & 276.74 & $15.97 \%$ \\
\hline INCB032304, Comp 5 & 23.38 & $1.35 \%$ \\
\hline INCB032304*Phosphate & 0.00 & $0.00 \%$ \\
\hline Sodium Phosphate & 0.00 & $0.00 \%$ \\
\hline Pinacol,kg & 72.08 & $4.16 \%$ \\
\hline Acetaldehyde, $\mathrm{kg}$ & 30.63 & $1.77 \%$ \\
\hline Ethanol & 32.04 & $1.85 \%$ \\
\hline Methanol & 0.00 & $0.00 \%$ \\
\hline Potassium Chloride,kg & 99.73 & $5.76 \%$ \\
\hline paraformaldehyde,kg & 1.94 & $0.11 \%$ \\
\hline $\mathrm{DBU} * \mathrm{HCl}$ & 0.00 & $0.00 \%$ \\
\hline Carbon Dioxide,kg & 0.00 & $0.00 \%$ \\
\hline DBU & 0.00 & $0.00 \%$ \\
\hline INCB032181, Comp 8 & 0.00 & $0.00 \%$ \\
\hline INCB032309, Comp 9 & 0.00 & $0.00 \%$ \\
\hline INCB032306, Comp 10R & 0.00 & $0.00 \%$ \\
\hline TBME,kg & 0.00 & $0.00 \%$ \\
\hline Heptane,kg & 938.38 & $54.15 \%$ \\
\hline Cesium Chloride, $\mathrm{kg}$ & 0.00 & $0.00 \%$ \\
\hline Isopropanol,kg & 0.00 & $0.00 \%$ \\
\hline Lithium Tetrafluoroborate & 0.00 & $0.00 \%$ \\
\hline Sodium Bicarbonate,kg & 0.00 & $0.00 \%$ \\
\hline Ammonium hydroxide, $\mathrm{kg}$ & 0.00 & $0.00 \%$ \\
\hline Cesium Carbonate,kg & 0.00 & $0.00 \%$ \\
\hline INCB018424, Comp 11 & 0.00 & $0.00 \%$ \\
\hline INCB021499,kg & 0.00 & $0.00 \%$ \\
\hline 85\% Phosphoric acid,kg & 0.00 & $0.00 \%$ \\
\hline INCB018424 Phosphate & 0.00 & $0.00 \%$ \\
\hline Trimethylsilylethanol,kg & 5.69 & $0.33 \%$ \\
\hline Hydrogen & 0.00 & $0.00 \%$ \\
\hline pyrimidine sodium & 0.00 & $0.00 \%$ \\
\hline DCM, methylene chloride & 0.00 & $0.00 \%$ \\
\hline DME, Dimethoxyethane & 0.00 & $0.00 \%$ \\
\hline Mineral Oil & 11.49 & $0.66 \%$ \\
\hline Total Weight per Batch,kg & 10202.95 & $588.80 \%$ \\
\hline Stream Density, kg/L & 0.94 & \\
\hline Total Volume, L & 10797.50 & \\
\hline Total Volume, Gal & 2852.71 & \\
\hline
\end{tabular}


Ampac Fine Chemicals

Combined Heat and Power Project

Hazardous Solvent and Aqueous Streams

ACC-342.3 Solvent

\begin{tabular}{|c|c|c|}
\hline Chemical & Wt. & $\%$ \\
\hline Hydrochloric Acid, kg & 0.00 & $0.00 \%$ \\
\hline Potassium Borate?, kg & 0.00 & $0.00 \%$ \\
\hline Paladium catalyst,kg & 0.00 & $0.00 \%$ \\
\hline Water, kg & 86.93 & $2.77 \%$ \\
\hline Acetonitrile,kg & 0.01 & $0.00 \%$ \\
\hline 4-Chloro (Compound 1) & 0.00 & $0.00 \%$ \\
\hline SEM-Cl (compound 2) & 0.00 & $0.00 \%$ \\
\hline Ethyl Acetate, $\mathrm{kg}$ & 0.00 & $0.00 \%$ \\
\hline $\mathrm{NaOH}, \mathrm{kg}$ & 0.00 & $0.00 \%$ \\
\hline Charcoal & 0.00 & $0.00 \%$ \\
\hline Celite & 0.00 & $0.00 \%$ \\
\hline Dimethylacetamide DMAC & 0.00 & $0.00 \%$ \\
\hline Sodium Hydride, $60 \%$ & 0.00 & $0.00 \%$ \\
\hline Sodium Chloride, $\mathrm{kg}$ & 0.00 & $0.00 \%$ \\
\hline WPT1710-225 & 0.00 & $0.00 \%$ \\
\hline Tetrahydrofuran,kg & 0.00 & $0.00 \%$ \\
\hline INCB032304, Comp 5 & 0.00 & $0.00 \%$ \\
\hline INCB032304*Phosphate & 0.00 & $0.00 \%$ \\
\hline Sodium Phosphate & 0.00 & $0.00 \%$ \\
\hline Pinacol,kg & 0.00 & $0.00 \%$ \\
\hline Acetaldehyde, $\mathrm{kg}$ & 0.00 & $0.00 \%$ \\
\hline Ethanol & 0.00 & $0.00 \%$ \\
\hline Methanol & 299.39 & $9.53 \%$ \\
\hline Potassium Chloride,kg & 0.00 & $0.00 \%$ \\
\hline paraformaldehyde,kg & 0.00 & $0.00 \%$ \\
\hline $\mathrm{DBU}{ }^{*} \mathrm{HCl}$ & 0.00 & $0.00 \%$ \\
\hline Carbon Dioxide,kg & 0.00 & $0.00 \%$ \\
\hline DBU & 0.00 & $0.00 \%$ \\
\hline INCB032181, Comp 8 & 2.05 & $0.07 \%$ \\
\hline INCB032309, Comp 9 & 0.00 & $0.00 \%$ \\
\hline INCB032306, Comp 10R & 0.00 & $0.00 \%$ \\
\hline TBME,kg & 2753.11 & $87.64 \%$ \\
\hline Heptane,kg & 0.00 & $0.00 \%$ \\
\hline Cesium Chloride, $\mathrm{kg}$ & 0.00 & $0.00 \%$ \\
\hline Isopropanol,kg & 0.00 & $0.00 \%$ \\
\hline Lithium Tetrafluoroborate & 0.00 & $0.00 \%$ \\
\hline Sodium Bicarbonate, $\mathrm{kg}$ & 0.00 & $0.00 \%$ \\
\hline Ammonium hydroxide, $\mathrm{kg}$ & 0.00 & $0.00 \%$ \\
\hline Cesium Carbonate,kg & 0.00 & $0.00 \%$ \\
\hline INCB018424, Comp 11 & 0.00 & $0.00 \%$ \\
\hline INCB021499, kg & 0.00 & $0.00 \%$ \\
\hline 85\% Phosphoric acid,kg & 0.00 & $0.00 \%$ \\
\hline INCB018424 Phosphate & 0.00 & $0.00 \%$ \\
\hline Trimethylsilylethanol,kg & 0.00 & $0.00 \%$ \\
\hline Hydrogen & 0.00 & $0.00 \%$ \\
\hline pyrimidine sodium & 0.00 & $0.00 \%$ \\
\hline DCM, methylene chloride & 0.00 & $0.00 \%$ \\
\hline DME, Dimethoxyethane & 0.00 & $0.00 \%$ \\
\hline Mineral Oil & 0.00 & $0.00 \%$ \\
\hline Total Weight per Batch,kg & 3141.49 & $100.00 \%$ \\
\hline Stream Density, kg/L & 0.75 & \\
\hline Total Volume, L & 4188.04 & \\
\hline Total Volume, Gal & 1106.48 & \\
\hline
\end{tabular}

ACC-342.3 Aqueous

\begin{tabular}{|c|c|c|}
\hline Chemical & Wt. & $\%$ \\
\hline Hydrochloric Acid, kg & 0.00 & $0.00 \%$ \\
\hline Potassium Borate?, kg & 0.00 & $0.00 \%$ \\
\hline Paladium catalyst,kg & 0.00 & $0.00 \%$ \\
\hline Water, kg & 3859.53 & $81.02 \%$ \\
\hline Acetonitrile,kg & 196.45 & $4.12 \%$ \\
\hline 4-Chloro (Compound 1) & 0.00 & $0.00 \%$ \\
\hline SEM-Cl (compound 2) & 0.00 & $0.00 \%$ \\
\hline Ethyl Acetate, $\mathrm{kg}$ & 0.00 & $0.00 \%$ \\
\hline $\mathrm{NaOH}, \mathrm{kg}$ & 0.00 & $0.00 \%$ \\
\hline Charcoal & 0.00 & $0.00 \%$ \\
\hline Celite & 0.00 & $0.00 \%$ \\
\hline Dimethylacetamide DMAC & 0.00 & $0.00 \%$ \\
\hline Sodium Hydride, $60 \%$ & 0.00 & $0.00 \%$ \\
\hline Sodium Chloride, kg & 215.88 & $4.53 \%$ \\
\hline WPT1710-225 & 0.00 & $0.00 \%$ \\
\hline Tetrahydrofuran, $\mathrm{kg}$ & 0.00 & $0.00 \%$ \\
\hline INCB032304, Comp 5 & 0.63 & $0.01 \%$ \\
\hline INCB032304*Phosphate & 0.00 & $0.00 \%$ \\
\hline Sodium Phosphate & 0.00 & $0.00 \%$ \\
\hline Pinacol,kg & 0.00 & $0.00 \%$ \\
\hline Acetaldehyde, $\mathrm{kg}$ & 0.00 & $0.00 \%$ \\
\hline Ethanol & 0.00 & $0.00 \%$ \\
\hline Methanol & 0.00 & $0.00 \%$ \\
\hline Potassium Chloride, $\mathrm{kg}$ & 0.00 & $0.00 \%$ \\
\hline paraformaldehyde,kg & 0.00 & $0.00 \%$ \\
\hline $\mathrm{DBU}{ }^{*} \mathrm{HCl}$ & 0.00 & $0.00 \%$ \\
\hline Carbon Dioxide,kg & 0.00 & $0.00 \%$ \\
\hline DBU & 114.64 & $2.41 \%$ \\
\hline INCB032181, Comp 8 & 5.10 & $0.11 \%$ \\
\hline INCB032309, Comp 9 & 13.43 & $0.28 \%$ \\
\hline INCB032306, Comp 10R & 0.00 & $0.00 \%$ \\
\hline TBME,kg & 334.52 & $7.02 \%$ \\
\hline Heptane,kg & 0.00 & $0.00 \%$ \\
\hline Cesium Chloride, $\mathrm{kg}$ & 0.00 & $0.00 \%$ \\
\hline Isopropanol,kg & 0.00 & $0.00 \%$ \\
\hline Lithium Tetrafluoroborate & 0.00 & $0.00 \%$ \\
\hline Sodium Bicarbonate,kg & 23.45 & $0.49 \%$ \\
\hline Ammonium hydroxide, $\mathrm{kg}$ & 0.00 & $0.00 \%$ \\
\hline Cesium Carbonate,kg & 0.00 & $0.00 \%$ \\
\hline INCB018424, Comp 11 & 0.00 & $0.00 \%$ \\
\hline INCB021499,kg & 0.00 & $0.00 \%$ \\
\hline 85\% Phosphoric acid,kg & 0.00 & $0.00 \%$ \\
\hline INCB018424 Phosphate & 0.00 & $0.00 \%$ \\
\hline Trimethylsilylethanol,kg & 0.00 & $0.00 \%$ \\
\hline Hydrogen & 0.00 & $0.00 \%$ \\
\hline pyrimidine sodium & 0.00 & $0.00 \%$ \\
\hline DCM, methylene chloride & 0.00 & $0.00 \%$ \\
\hline DME, Dimethoxyethane & 0.00 & $0.00 \%$ \\
\hline Mineral Oil & 0.00 & $0.00 \%$ \\
\hline Total Weight per Batch,kg & 4763.63 & $100.00 \%$ \\
\hline Stream Density, kg/L & 0.99 & \\
\hline Total Volume, L & 4805.78 & \\
\hline Total Volume, Gal & 1269.69 & \\
\hline
\end{tabular}

S:IDocumentation CenterlProcessI340-IncytelACC340-2010VACC340-Mass Balancelmb-ACC340-R31.xIs 
Ampac Fine Chemicals

Combined Heat and Power Project

Hazardous Solvent and Aqueous Streams

ACC-342.4 Solvent

\begin{tabular}{|c|c|c|}
\hline Chemical & Wt. & $\%$ \\
\hline INCB032183, WPT1710-212 & 0.00 & $0.00 \%$ \\
\hline INCB032182, Comp 3 & 0.00 & $0.00 \%$ \\
\hline Potassium Carbonate,kg & 0.00 & $0.00 \%$ \\
\hline 1-Butanol,kg & 0.00 & $0.00 \%$ \\
\hline Hydrochloric Acid, kg & 0.00 & $0.00 \%$ \\
\hline Potassium Borate?, kg & 0.00 & $0.00 \%$ \\
\hline Paladium catalyst,kg & 0.00 & $0.00 \%$ \\
\hline Water, kg & 40.80 & $0.39 \%$ \\
\hline Acetonitrile,kg & 2263.27 & $21.41 \%$ \\
\hline 4-Chloro (Compound 1) & 0.00 & $0.00 \%$ \\
\hline SEM-Cl (compound 2) & 0.00 & $0.00 \%$ \\
\hline Ethyl Acetate, $\mathrm{kg}$ & 2611.45 & $24.70 \%$ \\
\hline $\mathrm{NaOH}, \mathrm{kg}$ & 0.00 & $0.00 \%$ \\
\hline Charcoal & 0.00 & $0.00 \%$ \\
\hline Celite & 0.00 & $0.00 \%$ \\
\hline Dimethylacetamide DMAC & 0.00 & $0.00 \%$ \\
\hline Sodium Hydride, $60 \%$ & 0.00 & $0.00 \%$ \\
\hline Sodium Chloride, $\mathrm{kg}$ & 0.00 & $0.00 \%$ \\
\hline WPT1710-225 & 0.00 & $0.00 \%$ \\
\hline Tetrahydrofuran,kg & 0.00 & $0.00 \%$ \\
\hline INCB032304, Comp 5 & 0.00 & $0.00 \%$ \\
\hline INCB032304*Phosphate & 0.00 & $0.00 \%$ \\
\hline Sodium Phosphate & 0.00 & $0.00 \%$ \\
\hline Pinacol,kg & 0.00 & $0.00 \%$ \\
\hline Acetaldehyde, $\mathrm{kg}$ & 0.00 & $0.00 \%$ \\
\hline Ethanol & 0.00 & $0.00 \%$ \\
\hline Methanol & 0.00 & $0.00 \%$ \\
\hline Potassium Chloride,kg & 0.00 & $0.00 \%$ \\
\hline paraformaldehyde, $\mathrm{kg}$ & 0.00 & $0.00 \%$ \\
\hline $\mathrm{DBU} * \mathrm{HCl}$ & 0.00 & $0.00 \%$ \\
\hline Carbon Dioxide,kg & 0.00 & $0.00 \%$ \\
\hline DBU & 0.00 & $0.00 \%$ \\
\hline INCB032181, Comp 8 & 1.36 & $0.01 \%$ \\
\hline INCB032309, Comp 9 & 0.00 & $0.00 \%$ \\
\hline INCB032305, Comp 10S & 0.00 & $0.00 \%$ \\
\hline TBME,kg & 0.00 & $0.00 \%$ \\
\hline Heptane,kg & 3446.67 & $32.60 \%$ \\
\hline Isopropanol,kg & 2207.45 & $20.88 \%$ \\
\hline Boron Trifluoride & 0.00 & $0.00 \%$ \\
\hline Diethylether & 0.00 & $0.00 \%$ \\
\hline Sodium Bicarbonate,kg & 0.00 & $0.00 \%$ \\
\hline Ammonium hydroxide, $\mathrm{kg}$ & 0.00 & $0.00 \%$ \\
\hline INCB018424, Comp 11 & 0.00 & $0.00 \%$ \\
\hline INCB021499,kg & 0.00 & $0.00 \%$ \\
\hline 85\% Phosphoric acid,kg & 0.00 & $0.00 \%$ \\
\hline INCB018424 Phosphate & 0.00 & $0.00 \%$ \\
\hline Vinyltrimethylsilylane,kg & 0.00 & $0.00 \%$ \\
\hline Trimethylsilylethanol,kg & 0.00 & $0.00 \%$ \\
\hline Fluoroboric acid & 0.00 & $0.00 \%$ \\
\hline Boric acid & 0.00 & $0.00 \%$ \\
\hline Ammonium tetrafluoroboride & 0.00 & $0.00 \%$ \\
\hline Hydrogen & 0.00 & $0.00 \%$ \\
\hline pyrimidine sodium & 0.00 & $0.00 \%$ \\
\hline DCM, methylene chloride & 0.00 & $0.00 \%$ \\
\hline DME, Dimethoxyethane & 0.00 & $0.00 \%$ \\
\hline Mineral Oil & 0.00 & $0.00 \%$ \\
\hline Total Weight per Batch,kg & 10571.01 & $100.00 \%$ \\
\hline Stream Density, kg/L & 0.77 & \\
\hline Total Volume, L & 13716.01 & \\
\hline Total Volume, Gal & 3623.78 & \\
\hline
\end{tabular}

ACC-342.4 Aqueous

\begin{tabular}{|c|c|c|}
\hline Chemical & Wt. & $\%$ \\
\hline INCB032183, WPT1710-212 & 0.00 & $0.00 \%$ \\
\hline INCB032182, Comp 3 & 0.00 & $0.00 \%$ \\
\hline Potassium Carbonate,kg & 0.00 & $0.00 \%$ \\
\hline 1-Butanol,kg & 0.00 & $0.00 \%$ \\
\hline Hydrochloric Acid, kg & 0.00 & $0.00 \%$ \\
\hline Potassium Borate?, kg & 0.00 & $0.00 \%$ \\
\hline Paladium catalyst,kg & 0.00 & $0.00 \%$ \\
\hline Water, kg & 4167.42 & $79.79 \%$ \\
\hline Acetonitrile,kg & 341.73 & $6.54 \%$ \\
\hline 4-Chloro (Compound 1) & 0.00 & $0.00 \%$ \\
\hline SEM-Cl (compound 2) & 0.00 & $0.00 \%$ \\
\hline Ethyl Acetate, $\mathrm{kg}$ & 180.61 & $3.46 \%$ \\
\hline $\mathrm{NaOH}, \mathrm{kg}$ & 0.00 & $0.00 \%$ \\
\hline Charcoal & 0.00 & $0.00 \%$ \\
\hline Celite & 0.00 & $0.00 \%$ \\
\hline Dimethylacetamide DMAC & 0.00 & $0.00 \%$ \\
\hline Sodium Hydride, $60 \%$ & 0.00 & $0.00 \%$ \\
\hline Sodium Chloride, $\mathrm{kg}$ & 386.19 & $7.39 \%$ \\
\hline WPT1710-225 & 0.00 & $0.00 \%$ \\
\hline Tetrahydrofuran,kg & 0.00 & $0.00 \%$ \\
\hline INCB032304, Comp 5 & 0.00 & $0.00 \%$ \\
\hline INCB032304*Phosphate & 0.00 & $0.00 \%$ \\
\hline Sodium Phosphate & 0.00 & $0.00 \%$ \\
\hline Pinacol,kg & 0.00 & $0.00 \%$ \\
\hline Acetaldehyde, kg & 0.00 & $0.00 \%$ \\
\hline Ethanol & 0.00 & $0.00 \%$ \\
\hline Methanol & 0.00 & $0.00 \%$ \\
\hline Potassium Chloride, $\mathrm{kg}$ & 0.00 & $0.00 \%$ \\
\hline paraformaldehyde, $\mathrm{kg}$ & 0.00 & $0.00 \%$ \\
\hline $\mathrm{DBU} * \mathrm{HCl}$ & 0.00 & $0.00 \%$ \\
\hline Carbon Dioxide,kg & 0.00 & $0.00 \%$ \\
\hline DBU & 96.25 & $1.84 \%$ \\
\hline INCB032181, Comp 8 & 0.94 & $0.02 \%$ \\
\hline INCB032309, Comp 9 & 28.98 & $0.55 \%$ \\
\hline INCB032305, Comp 10S & 0.02 & $0.00 \%$ \\
\hline TBME,kg & 0.00 & $0.00 \%$ \\
\hline Heptane,kg & 0.00 & $0.00 \%$ \\
\hline Isopropanol,kg & 0.00 & $0.00 \%$ \\
\hline Boron Trifluoride & 0.00 & $0.00 \%$ \\
\hline Diethylether & 0.00 & $0.00 \%$ \\
\hline Sodium Bicarbonate, $\mathrm{kg}$ & 20.81 & $0.40 \%$ \\
\hline Ammonium hydroxide, $\mathrm{kg}$ & 0.00 & $0.00 \%$ \\
\hline INCB018424, Comp 11 & 0.00 & $0.00 \%$ \\
\hline INCB021499,kg & 0.00 & $0.00 \%$ \\
\hline 85\% Phosphoric acid,kg & 0.00 & $0.00 \%$ \\
\hline INCB018424 Phosphate & 0.00 & $0.00 \%$ \\
\hline Vinyltrimethylsilylane,kg & 0.00 & $0.00 \%$ \\
\hline Trimethylsilylethanol,kg & 0.00 & $0.00 \%$ \\
\hline Fluoroboric acid & 0.00 & $0.00 \%$ \\
\hline Boric acid & 0.00 & $0.00 \%$ \\
\hline Ammonium tetrafluoroboride & 0.00 & $0.00 \%$ \\
\hline Hydrogen & 0.00 & $0.00 \%$ \\
\hline pyrimidine sodium & 0.00 & $0.00 \%$ \\
\hline DCM, methylene chloride & 0.00 & $0.00 \%$ \\
\hline DME, Dimethoxyethane & 0.00 & $0.00 \%$ \\
\hline Mineral Oil & 0.00 & $0.00 \%$ \\
\hline Total Weight per Batch,kg & 5222.95 & $100.00 \%$ \\
\hline Stream Density, kg/L & 1.02 & \\
\hline Total Volume, L & 5117.85 & \\
\hline Total Volume, Gal & 1352.14 & \\
\hline
\end{tabular}

S:IDocumentation CenterIProcessI340-IncytelACC340-2011VACC340 - Mass Balancelmb-ACC342.4 Southline.xls 
Ampac Fine Chemicals

Combined Heat and Power Project

Hazardous Solvent and Aqueous Streams

ACC-341/343 Solvent

\begin{tabular}{|l|c|c|}
\hline \multicolumn{1}{|c|}{ Chemical } & Wt. & $\%$ \\
\hline MTBE & 199.2 & $100.0 \%$ \\
\hline Total Weight per Batch, kg & 199.2 & $100.0 \%$ \\
Stream Density, kg/L & 0.75 & \\
Total Volume, L & 265.6 & \\
Total Volume, Gal & 70.2 & \\
\hline
\end{tabular}

S:IDocumentation CenterIProcessI340-IncytelACC341_343-2010IACC341_343 Mass Balance 2010IMB ACC-341 \& 343.xIs

\section{NOTES}

Mass balance does not account for cleaning or CSP regeneration, etc...

No aqueous waste streams produced by this process 
Ampac Fine Chemicals

Combined Heat and Power Project

Hazardous Solvent and Aqueous Streams

ACC-340.1 Solvent

\begin{tabular}{|c|c|c|}
\hline Chemical & Wt. & $\%$ \\
\hline Water, kg & 201.40 & $3.29 \%$ \\
\hline Acetonitrile,kg & 1836.50 & $30.02 \%$ \\
\hline 4-Chloro (Compound 1) & 0.00 & $0.00 \%$ \\
\hline SEM-Cl (compound 2) & 0.00 & $0.00 \%$ \\
\hline Ethyl Acetate, kg & 2142.82 & $35.03 \%$ \\
\hline $\mathrm{NaOH}, \mathrm{kg}$ & 0.00 & $0.00 \%$ \\
\hline Charcoal & 0.00 & $0.00 \%$ \\
\hline Celite & 0.00 & $0.00 \%$ \\
\hline Dimethylacetamide DMAC & 0.00 & $0.00 \%$ \\
\hline Sodium Hydride,60\% & 0.00 & $0.00 \%$ \\
\hline Sodium Chloride, $\mathrm{kg}$ & 0.00 & $0.00 \%$ \\
\hline WPT1710-225 & 0.00 & $0.00 \%$ \\
\hline Tetrahydrofuran,kg & 0.00 & $0.00 \%$ \\
\hline INCB032304, Comp 5 & 0.00 & $0.00 \%$ \\
\hline INCB032304*Phosphate & 0.00 & $0.00 \%$ \\
\hline Sodium Phosphate & 0.00 & $0.00 \%$ \\
\hline Pinacol,kg & 0.00 & $0.00 \%$ \\
\hline Acetaldehyde, $\mathrm{kg}$ & 0.00 & $0.00 \%$ \\
\hline Ethanol & 0.00 & $0.00 \%$ \\
\hline Methanol & 0.00 & $0.00 \%$ \\
\hline Potassium Chloride,kg & 0.00 & $0.00 \%$ \\
\hline paraformaldehyde,kg & 0.13 & $0.00 \%$ \\
\hline $\mathrm{DBU} * \mathrm{HCl}$ & 0.00 & $0.00 \%$ \\
\hline Carbon Dioxide,kg & 0.00 & $0.00 \%$ \\
\hline DBU & 0.00 & $0.00 \%$ \\
\hline INCB032181, Comp 8 & 0.00 & $0.00 \%$ \\
\hline INCB032309, Comp 9 & 0.00 & $0.00 \%$ \\
\hline INCB032306, Comp 10R & 0.00 & $0.00 \%$ \\
\hline TBME,kg & 837.80 & $13.70 \%$ \\
\hline Heptane,kg & 0.00 & $0.00 \%$ \\
\hline Cesium Chloride, $\mathrm{kg}$ & 0.00 & $0.00 \%$ \\
\hline Isopropanol,kg & 1072.38 & $17.53 \%$ \\
\hline Boron Trifluoride & 0.00 & $0.00 \%$ \\
\hline Sodium Bicarbonate,kg & 0.00 & $0.00 \%$ \\
\hline Ammonium hydroxide, $\mathrm{kg}$ & 8.77 & $0.14 \%$ \\
\hline Cesium Carbonate, $\mathrm{kg}$ & 0.00 & $0.00 \%$ \\
\hline INCB018424, Comp 11 & 0.00 & $0.00 \%$ \\
\hline INCB021499,kg & 0.00 & $0.00 \%$ \\
\hline 85\% Phosphoric acid,kg & 0.00 & $0.00 \%$ \\
\hline INCB018424 Phosphate & 0.00 & $0.00 \%$ \\
\hline Trimethylsilylethanol,kg & 17.11 & $0.28 \%$ \\
\hline Hydrogen & 0.00 & $0.00 \%$ \\
\hline pyrimidine sodium & 0.00 & $0.00 \%$ \\
\hline DCM, methylene chloride & 0.00 & $0.00 \%$ \\
\hline DME, Dimethoxyethane & 0.00 & $0.00 \%$ \\
\hline Mineral Oil & 0.00 & $0.00 \%$ \\
\hline Total Weight per Batch,kg & 6116.91 & $100.00 \%$ \\
\hline Stream Density, kg/L & 0.82 & \\
\hline Total Volume, L & 7457.61 & \\
\hline Total Volume, Gal & 1970.31 & \\
\hline
\end{tabular}

ACC-340.1 Aqueous

\begin{tabular}{|c|c|c|}
\hline Chemical & Wt. & $\%$ \\
\hline Water, kg & 1842.15 & $81.86 \%$ \\
\hline Acetonitrile,kg & 0.00 & $0.00 \%$ \\
\hline 4-Chloro (Compound 1) & 0.00 & $0.00 \%$ \\
\hline SEM-Cl (compound 2) & 0.00 & $0.00 \%$ \\
\hline Ethyl Acetate, kg & 160.27 & $7.12 \%$ \\
\hline $\mathrm{NaOH}, \mathrm{kg}$ & 0.00 & $0.00 \%$ \\
\hline Charcoal & 0.00 & $0.00 \%$ \\
\hline Celite & 0.00 & $0.00 \%$ \\
\hline Dimethylacetamide DMAC & 0.00 & $0.00 \%$ \\
\hline Sodium Hydride, $60 \%$ & 0.00 & $0.00 \%$ \\
\hline Sodium Chloride, $\mathrm{kg}$ & 125.19 & $5.56 \%$ \\
\hline WPT1710-225 & 0.00 & $0.00 \%$ \\
\hline Tetrahydrofuran,kg & 0.00 & $0.00 \%$ \\
\hline INCB032304, Comp 5 & 0.00 & $0.00 \%$ \\
\hline INCB032304*Phosphate & 0.00 & $0.00 \%$ \\
\hline Sodium Phosphate & 0.00 & $0.00 \%$ \\
\hline Pinacol,kg & 0.00 & $0.00 \%$ \\
\hline Acetaldehyde, $\mathrm{kg}$ & 0.00 & $0.00 \%$ \\
\hline Ethanol & 0.00 & $0.00 \%$ \\
\hline Methanol & 0.00 & $0.00 \%$ \\
\hline Potassium Chloride,kg & 0.00 & $0.00 \%$ \\
\hline paraformaldehyde,kg & 2.19 & $0.10 \%$ \\
\hline $\mathrm{DBU} * \mathrm{HCl}$ & 0.00 & $0.00 \%$ \\
\hline Carbon Dioxide,kg & 0.00 & $0.00 \%$ \\
\hline DBU & 0.00 & $0.00 \%$ \\
\hline INCB032181, Comp 8 & 0.00 & $0.00 \%$ \\
\hline INCB032309, Comp 9 & 0.00 & $0.00 \%$ \\
\hline INCB032306, Comp 10R & 0.01 & $0.00 \%$ \\
\hline TBME,kg & 0.00 & $0.00 \%$ \\
\hline Heptane,kg & 0.00 & $0.00 \%$ \\
\hline Cesium Chloride, $\mathrm{kg}$ & 0.00 & $0.00 \%$ \\
\hline Isopropanol,kg & 0.00 & $0.00 \%$ \\
\hline Boron Trifluoride & 18.69 & $0.83 \%$ \\
\hline Sodium Bicarbonate,kg & 96.46 & $4.29 \%$ \\
\hline Ammonium hydroxide,kg & 0.00 & $0.00 \%$ \\
\hline Cesium Carbonate,kg & 0.00 & $0.00 \%$ \\
\hline INCB018424, Comp 11 & 2.80 & $0.12 \%$ \\
\hline INCB021499,kg & 0.00 & $0.00 \%$ \\
\hline 85\% Phosphoric acid,kg & 0.00 & $0.00 \%$ \\
\hline INCB018424 Phosphate & 0.00 & $0.00 \%$ \\
\hline Trimethylsilylethanol,kg & 2.58 & $0.11 \%$ \\
\hline Hydrogen & 0.00 & $0.00 \%$ \\
\hline pyrimidine sodium & 0.00 & $0.00 \%$ \\
\hline DCM, methylene chloride & 0.00 & $0.00 \%$ \\
\hline DME, Dimethoxyethane & 0.00 & $0.00 \%$ \\
\hline Mineral Oil & 0.00 & $0.00 \%$ \\
\hline Total Weight per Batch,kg & 2250.35 & $100.00 \%$ \\
\hline Stream Density, kg/L & 1.05 & \\
\hline Total Volume, L & 2152.10 & \\
\hline Total Volume, Gal & 568.59 & \\
\hline
\end{tabular}


Ampac Fine Chemicals

Combined Heat and Power Project

Hazardous Solvent and Aqueous Streams

ACC-340.2 Solvent

\begin{tabular}{|c|c|c|}
\hline Chemical & Wt. & $\%$ \\
\hline Water, kg & 4.99 & $0.13 \%$ \\
\hline Acetonitrile,kg & 0.00 & $0.00 \%$ \\
\hline 4-Chloro (Compound 1) & 0.00 & $0.00 \%$ \\
\hline SEM-Cl (compound 2) & 0.00 & $0.00 \%$ \\
\hline Ethyl Acetate, kg & 0.00 & $0.00 \%$ \\
\hline $\mathrm{NaOH}, \mathrm{kg}$ & 0.00 & $0.00 \%$ \\
\hline Charcoal & 0.00 & $0.00 \%$ \\
\hline Celite & 0.00 & $0.00 \%$ \\
\hline Dimethylacetamide DMAC & 0.00 & $0.00 \%$ \\
\hline Sodium Hydride, $60 \%$ & 0.00 & $0.00 \%$ \\
\hline Sodium Chloride, kg & 0.00 & $0.00 \%$ \\
\hline WPT1710-225 & 0.00 & $0.00 \%$ \\
\hline Tetrahydrofuran,kg & 0.00 & $0.00 \%$ \\
\hline INCB032304, Comp 5 & 0.00 & $0.00 \%$ \\
\hline INCB032304*Phosphate & 0.00 & $0.00 \%$ \\
\hline Sodium Phosphate & 0.00 & $0.00 \%$ \\
\hline Pinacol,kg & 0.00 & $0.00 \%$ \\
\hline Acetaldehyde, $\mathrm{kg}$ & 0.00 & $0.00 \%$ \\
\hline Ethanol & 0.00 & $0.00 \%$ \\
\hline Methanol & 0.00 & $0.00 \%$ \\
\hline Potassium Chloride,kg & 0.00 & $0.00 \%$ \\
\hline paraformaldehyde,kg & 0.00 & $0.00 \%$ \\
\hline $\mathrm{DBU} * \mathrm{HCl}$ & 0.00 & $0.00 \%$ \\
\hline Carbon Dioxide,kg & 0.00 & $0.00 \%$ \\
\hline DBU & 0.00 & $0.00 \%$ \\
\hline INCB032181, Comp 8 & 0.00 & $0.00 \%$ \\
\hline INCB032309, Comp 9 & 0.00 & $0.00 \%$ \\
\hline INCB032306, Comp 10R & 0.00 & $0.00 \%$ \\
\hline TBME,kg & 0.00 & $0.00 \%$ \\
\hline Heptane,kg & 361.03 & $9.54 \%$ \\
\hline Cesium Chloride, kg & 0.00 & $0.00 \%$ \\
\hline Isopropanol,kg & 835.45 & $22.08 \%$ \\
\hline Lithium Tetrafluoroborate & 0.00 & $0.00 \%$ \\
\hline Sodium Bicarbonate,kg & 0.00 & $0.00 \%$ \\
\hline Ammonium hydroxide,kg & 0.00 & $0.00 \%$ \\
\hline Cesium Carbonate,kg & 0.00 & $0.00 \%$ \\
\hline INCB018424, Comp 11 & 0.00 & $0.00 \%$ \\
\hline INCB021499,kg & 0.00 & $0.00 \%$ \\
\hline 85\% Phosphoric acid,kg & 0.00 & $0.00 \%$ \\
\hline INCB018424 Phosphate & 0.00 & $0.00 \%$ \\
\hline Trimethylsilylethanol,kg & 0.00 & $0.00 \%$ \\
\hline Hydrogen & 0.00 & $0.00 \%$ \\
\hline pyrimidine sodium & 0.00 & $0.00 \%$ \\
\hline DCM, methylene chloride & 2582.07 & $68.24 \%$ \\
\hline DME, Dimethoxyethane & 0.00 & $0.00 \%$ \\
\hline Mineral Oil & 0.00 & $0.00 \%$ \\
\hline Total Weight per Batch,kg & 3783.54 & $100.00 \%$ \\
\hline Stream Density, kg/L & 1.06 & \\
\hline Total Volume, L & 3556.30 & \\
\hline Total Volume, Gal & 939.58 & \\
\hline
\end{tabular}

S:IDocumentation Center|ProcessI340-IncytelACC340-20101ACC340-Mass Balancelmb-ACC340-R31.xIs

\section{NOTES}

Mass balance does not account for cleaning

No aqueous waste streams produced by this process 
Ampac Fine Chemicals

Combined Heat and Power Project

Hazardous Solvent and Aqueous Streams

ACC-340 Solvent

\begin{tabular}{|c|c|c|}
\hline Chemical & Wt. & $\%$ \\
\hline Water, kg & 0.00 & $0.0 \%$ \\
\hline Acetonitrile,kg & 0.00 & $0.0 \%$ \\
\hline 4-Chloro (Compound 1) & 0.00 & $0.0 \%$ \\
\hline SEM-CI (compound 2) & 0.00 & $0.0 \%$ \\
\hline Ethyl Acetate, kg & 0.00 & $0.0 \%$ \\
\hline $\mathrm{NaOH}, \mathrm{kg}$ & 0.00 & $0.0 \%$ \\
\hline Charcoal & 0.00 & $0.0 \%$ \\
\hline Celite & 0.00 & $0.0 \%$ \\
\hline Dimethylacetamide DMAC & 0.00 & $0.0 \%$ \\
\hline Sodium Hydride, $60 \%$ & 0.00 & $0.0 \%$ \\
\hline Sodium Chloride, kg & 0.00 & $0.0 \%$ \\
\hline WPT1710-225 & 0.00 & $0.0 \%$ \\
\hline Tetrahydrofuran, $\mathrm{kg}$ & 0.00 & $0.0 \%$ \\
\hline INCB032304, Comp 5 & 0.00 & $0.0 \%$ \\
\hline INCB032304*Phosphate & 0.00 & $0.0 \%$ \\
\hline Sodium Phosphate & 0.00 & $0.0 \%$ \\
\hline Pinacol,kg & 0.00 & $0.0 \%$ \\
\hline Acetaldehyde, $\mathrm{kg}$ & 0.00 & $0.0 \%$ \\
\hline Ethanol & 0.00 & $0.0 \%$ \\
\hline Methanol & 1166.52 & $30.4 \%$ \\
\hline Potassium Chloride,kg & 0.00 & $0.0 \%$ \\
\hline paraformaldehyde,kg & 0.00 & $0.0 \%$ \\
\hline $\mathrm{DBU} * \mathrm{HCl}$ & 0.00 & $0.0 \%$ \\
\hline Carbon Dioxide,kg & 0.00 & $0.0 \%$ \\
\hline DBU & 0.00 & $0.0 \%$ \\
\hline INCB032181, Comp 8 & 0.00 & $0.0 \%$ \\
\hline INCB032309, Comp 9 & 0.00 & $0.0 \%$ \\
\hline INCB032306, Comp 10R & 0.00 & $0.0 \%$ \\
\hline TBME,kg & 0.00 & $0.0 \%$ \\
\hline Heptane,kg & 2003.78 & $52.2 \%$ \\
\hline Cesium Chloride, kg & 0.00 & $0.0 \%$ \\
\hline Isopropanol,kg & 666.02 & $17.4 \%$ \\
\hline Lithium Tetrafluoroborate & 0.00 & $0.0 \%$ \\
\hline Sodium Bicarbonate,kg & 0.00 & $0.0 \%$ \\
\hline Ammonium hydroxide,kg & 0.00 & $0.0 \%$ \\
\hline Cesium Carbonate,kg & 0.00 & $0.0 \%$ \\
\hline INCB018424, Comp 11 & 0.00 & $0.0 \%$ \\
\hline INCB021499,kg & 0.00 & $0.0 \%$ \\
\hline 85\% Phosphoric acid,kg & 0.00 & $0.0 \%$ \\
\hline INCB018424 Phosphate & 0.00 & $0.0 \%$ \\
\hline Trimethylsilylethanol,kg & 0.00 & $0.0 \%$ \\
\hline Hydrogen & 0.00 & $0.0 \%$ \\
\hline pyrimidine sodium & 0.00 & $0.0 \%$ \\
\hline DCM, methylene chloride & 0.19 & $0.0 \%$ \\
\hline DME, Dimethoxyethane & 0.00 & $0.0 \%$ \\
\hline Mineral Oil & 0.00 & $0.0 \%$ \\
\hline Total Weight per Batch,kg & 3836.51 & $100.0 \%$ \\
\hline Stream Density, kg/L & 0.73 & \\
\hline Total Volume, L & 5270.06 & \\
\hline Total Volume, Gal & 1392.35 & \\
\hline
\end{tabular}

S:IDocumentation Center|ProcessI340-IncytelACC340-2010/ACC340-Mass Balancelmb-ACC340-R31.xls

\section{NOTES}

Mass balance does not account for cleaning

No aqueous waste streams produced by this process 


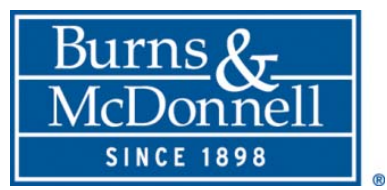

Burns \& McDonnell World Headquarters

9400 Ward Parkway

Kansas City, MO 64114

Phone: 816-333-9400

Fax: 816-333-3690

www.burnsmcd.com

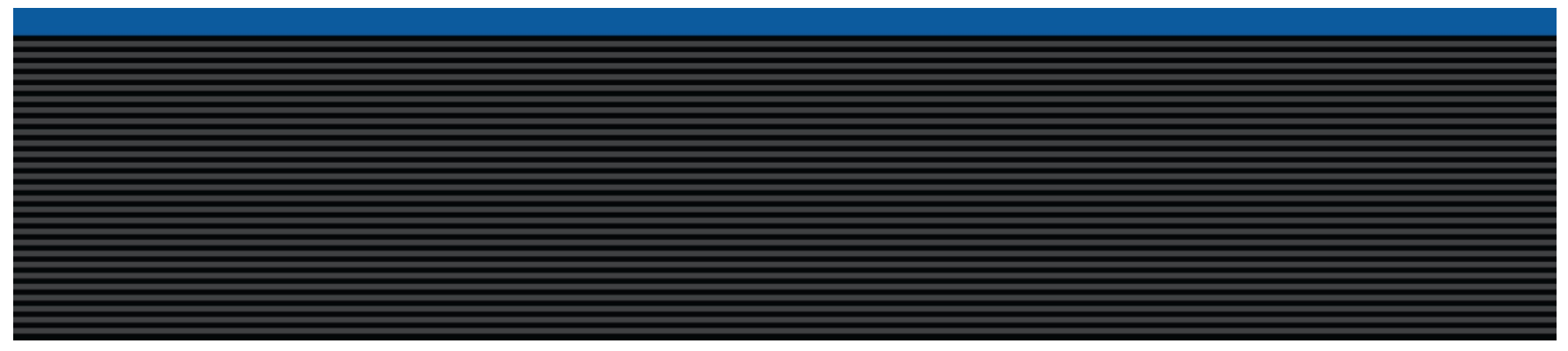

